\title{
Hydrology and Simulation of Ground-Water Flow in the Tooele Valley Ground-Water Basin, Tooele County, Utah
}

Prepared in cooperation with Tooele County

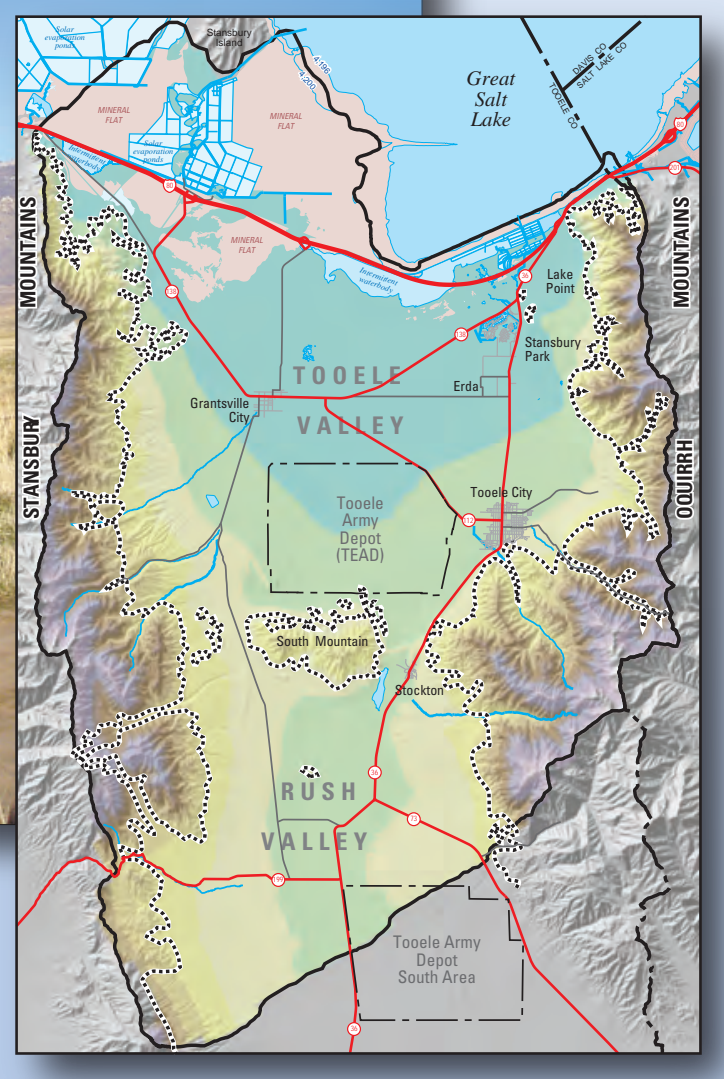

Scientific Investigations Report 2009-5154 
Cover. Photograph taken east of Tooele City looking northeast toward the Oquirrh Mountains. 


\section{Hydrology and Simulation of Ground-Water Flow in the Tooele Valley Ground-Water Basin, Tooele County, Utah}

By Bernard J. Stolp and Lynette E. Brooks

Prepared in cooperation with Tooele County

Scientific Investigations Report 2009-5154 


\title{
U.S. Department of the Interior \\ KEN SALAZAR, Secretary
}

\author{
U.S. Geological Survey \\ Suzette M. Kimball, Acting Director
}

U.S. Geological Survey, Reston, Virginia: 2009

For more information on the USGS - the Federal source for science about the Earth, its natural and living resources, natural hazards, and the environment, visit http://www.usgs.gov or call 1-888-ASK-USGS

For an overview of USGS information products, including maps, imagery, and publications, visit http://www.usgs.gov/pubprod

To order this and other USGS information products, visit http://store.usgs.gov

Any use of trade, product, or firm names is for descriptive purposes only and does not imply endorsement by the U.S. Government.

Although this report is in the public domain, permission must be secured from the individual copyright owners to reproduce any copyrighted materials contained within this report.

Suggested citation:

Stolp, B.J., and Brooks, L.E., 2009, Hydrology and simulation of ground-water flow in the Tooele Valley ground-water basin, Tooele County, Utah: U.S. Geological Survey Scientific Investigations Report 2009-5154, 86 p., 3 appendices, 1 pl. Available at http://pubs.usgs.gov/sir/2009/5154/. 


\section{Contents}

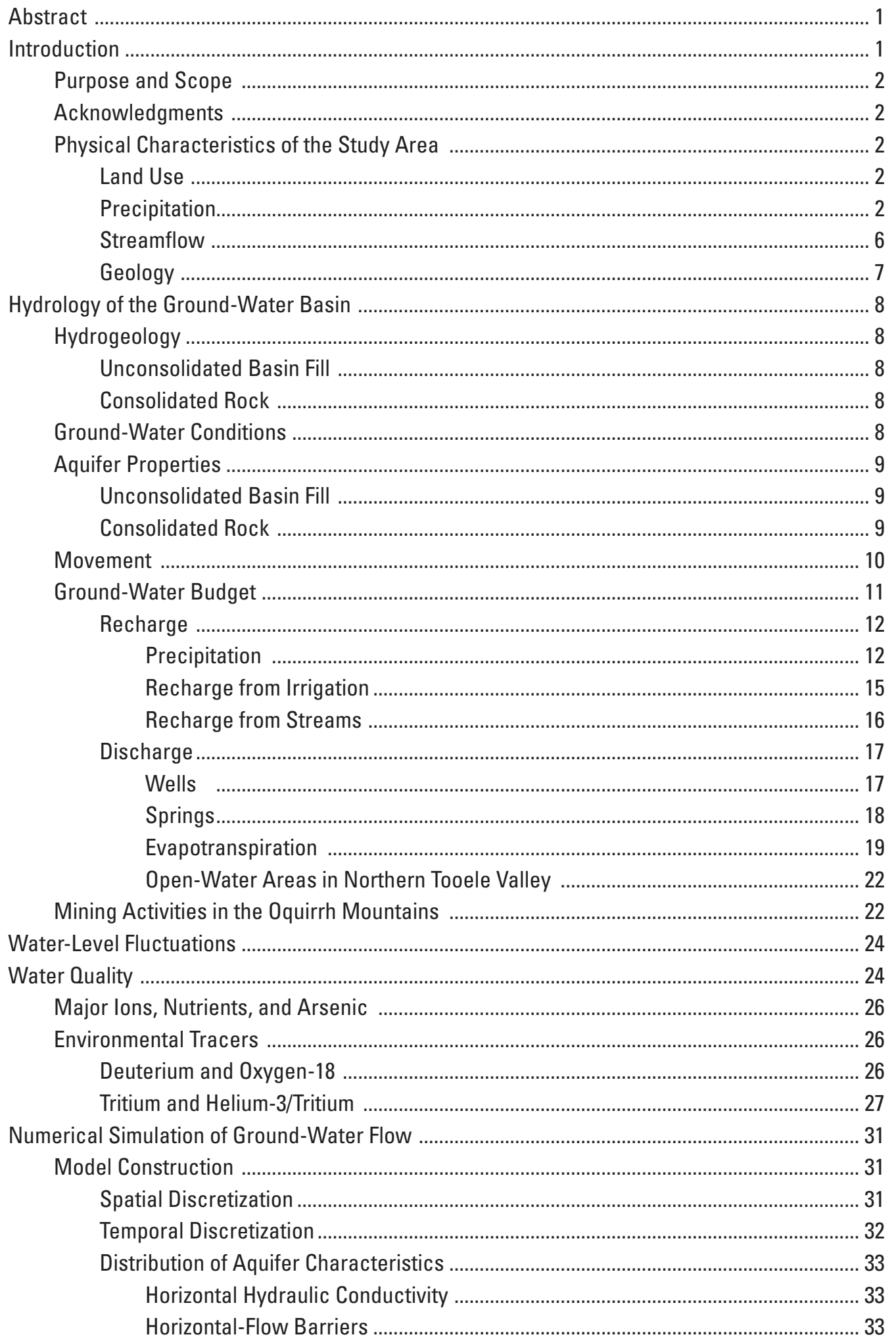


Vertical Hydraulic Conductivity ................................................................................. 36

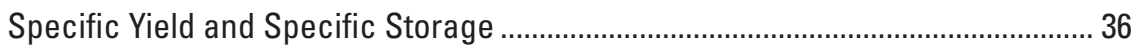

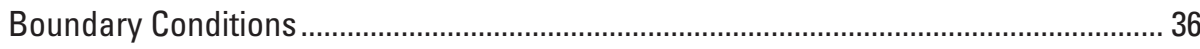

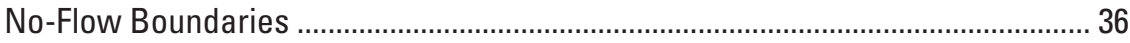

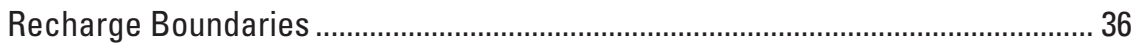

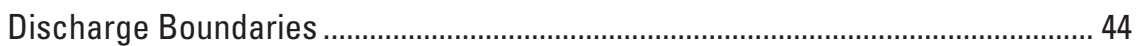

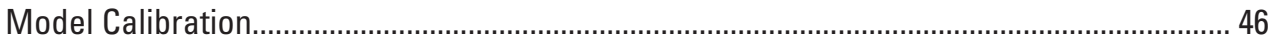

Parameter Adjustment and Sensitivity..................................................................... 48

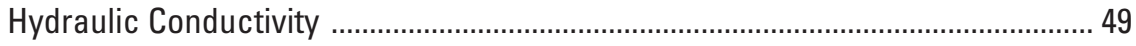

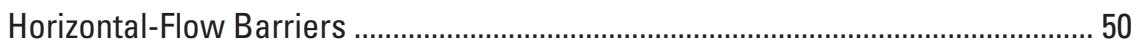

Specific Yield and Specific Storage .................................................................... 50

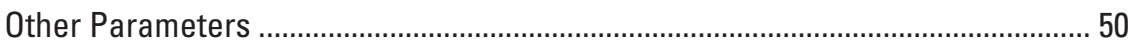

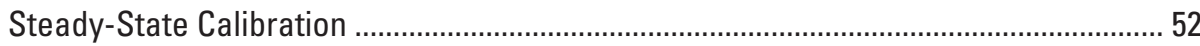

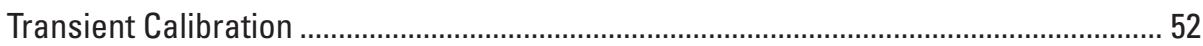

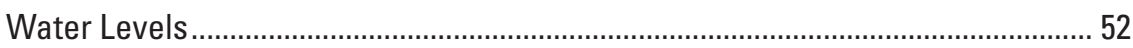

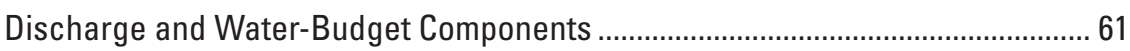

Sensitivity Analysis and Suggested Locations for Data Collection ......................................... 64

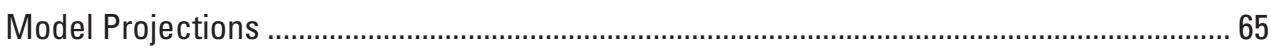

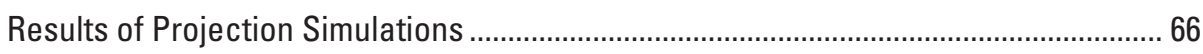

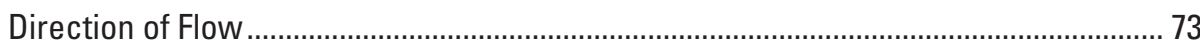

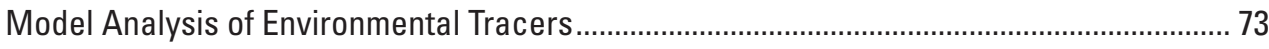

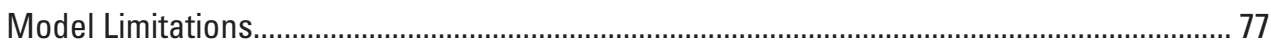

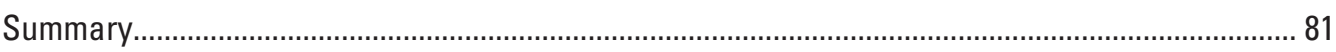

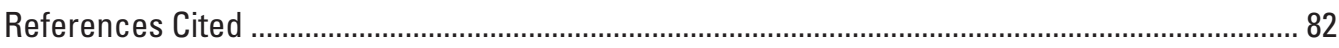

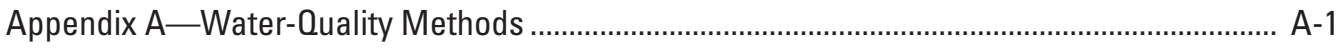

Introduction............................................................................................................

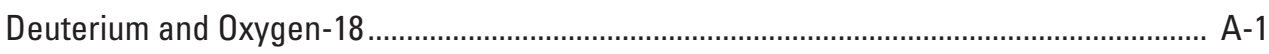

Helium-3/Tritium ……............................................................................................. A-1

Appendix B-Scoping Model for Evaluation of Ground-Water Withdrawals at the Carr Fork

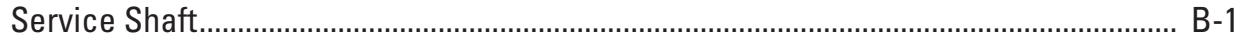

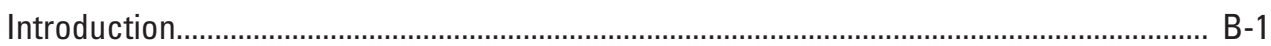

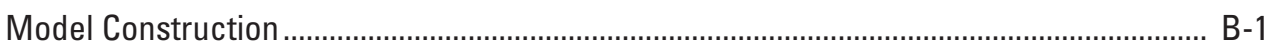

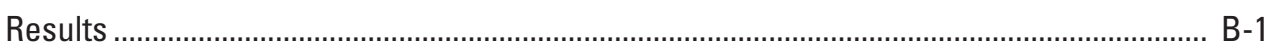

Appendix C—Data Tables .............................................................................................. C-1

Plate 1

\section{Figures}

1. Tooele Valley ground-water basin, Tooele County, Utah .................................................. 3

2. Numbering system for hydrologic-data sites in Utah .................................................. 4

3. Average annual precipitation for the period 1971-2000, Tooele Valley ground-water basin, Tooele County, Utah

4. Annual precipitation at Tooele City from 1968 to 2006, and cumulative departure from the 1971-2000 monthly average precipitation at Tooele City from 2003 to 2006, Tooele Valley ground-water basin, Tooele County, Utah 
5. Annual streamflow of South Willow Creek from 1971 to 2004, Tooele Valley groundwater basin, Tooele County, Utah

6. Approximate potentiometric surface, March 2003, Tooele Valley, Tooele County, Utah

7. Hydrologic areas used to delineate recharge, Tooele Valley ground-water basin, Tooele County, Utah ....

8. Annual ground-water withdrawals for irrigation and municipal uses, 1968-2006, Tooele Valley ground-water basin, Tooele County, Utah

9. Discharge at Mill Pond Spring and water levels at well (C-2-4)21ddb-1, Tooele Valley ground-water basin, Tooele County, Utah

10. Location and classification of evapotranspiration units, Tooele Valley groundwater basin, Tooele County, Utah

11. Water inflows and outflows for open water in northern Tooele Valley, Tooele Valley ground-water basin, Tooele County, Utah

12. Annual (A) and seasonal (B) water-level fluctuations at selected locations, Tooele Valley ground-water basin, Tooele Valley, Utah

13. Relation between deuterium $\left(\delta^{2} \mathrm{H}\right)$ and oxygen-18 $\left(\delta^{18} 0\right)$ in ground water and springs, Tooele Valley ground-water basin, Tooele County, Utah

14. Selected deuterium $\left({ }^{2} \mathrm{H}\right)$ and oxygen-18 $\left({ }^{18} \mathrm{O}\right)$ sampling locations and potentiometric surface, Tooele Valley ground-water basin, Tooele County, Utah

15. Helium-3/Tritium sampling locations, apparent age, and potentiometric surface, Tooele Valley ground-water basin, Tooele County, Utah

16. Model grid and location of active cells in the ground-water flow model, Tooele Valley ground-water basin, Tooele County, Utah

17. Final distribution of horizontal hydraulic-conductivity values and parameters of the basin fill as simulated in the ground-water flow model, Tooele Valley ground-water basin, Tooele County, Utah

18. Final distribution of horizontal-flow barriers in layer 3 and hydraulic-conductivity values and parameters of consolidated rock as simulated in the ground-water flow model, Tooele Valley ground-water basin, Tooele County, Utah

19. Final distribution of vertical hydraulic-conductivity values and parameters as simulated in the ground-water flow model, Tooele Valley ground-water basin, Tooele County, Utah

20. Final distribution of specific-yield and specific-storage values and parameters as simulated in the ground-water flow model, Tooele Valley ground-water basin, Tooele County, Utah

21. Areas of recharge parameters for precipitation and average annual recharge from precipitation simulated in the ground-water flow model, Tooele Valley groundwater basin, Tooele County, Utah

22. Zones of time-varying recharge from irrigation, area of irrigation with Carr Fork water during selected years, and multiplier array for recharge from irrigation simulated in the ground-water flow model, Tooele Valley ground-water basin, Tooele County, Utah

23. Recharge zones and average annual recharge from stream infiltration simulated in the ground-water flow model, Tooele Valley ground-water basin, Tooele County, Utah

24. Maximum evapotranspiration rate and area of possible discharge to adjacent mining areas simulated in the ground-water flow model, Tooele Valley groundwater basin, Tooele County, Utah 
25. Location of drains and streams simulated in the ground-water flow model, Tooele Valley ground-water basin, Tooele County, Utah

26. Location of flowing wells simulated in the ground-water flow model, Tooele Valley ground-water basin, Tooele County, Utah

27. Composite scaled sensitivity of observations to model parameters in the groundwater flow model, Tooele Valley ground-water basin, Tooele County, Utah 50

28. One-percent scaled sensitivity of stream and spring observations to selected model parameters simulated in the ground-water flow model, Tooele Valley ground-water basin, Tooele County, Utah 51

29. Water level simulated in the steady-state period of the ground-water flow model, and difference between simulated water level and water level measured in March 1969, Tooele Valley ground-water basin, Tooele County, Utah 54

30. Location of selected measured and simulated water-level fluctuations, Tooele Valley ground-water basin, Tooele County, Utah

31. Water level simulated at the end of each stress period in the ground-water flow model and water level measured from March 1969 to April 2004 at 27 sites, Tooele Valley ground-water basin, Tooele County, Utah

32. Water level simulated at the end of stress period 35 of the ground-water flow model and difference between simulated water level and water level measured in March-April 2003, Tooele Valley ground-water basin, Tooele County, Utah

33. Discharge simulated at the end of each stress period in the ground-water flow model and streamflow and spring discharge measured from 1968 to 2004, Tooele Valley ground-water basin, Tooele County, Utah

34. Location of simulated water levels with highest 1-percent scaled sensitivity in stress period 36 in layer 2 to selected model parameters, Tooele Valley ground-water basin, Tooele County, Utah

35. One-percent scaled sensitivity in stress period 36 in layer 2 to model parameter hfbtad1, Tooele Valley ground-water basin, Tooele County, Utah

36. Water-level change in model layer 2 at the end of 36 -year simulation (stress period 18), projection 1 of the ground-water flow model, Tooele Valley ground-water basin, Tooele County, Utah

37. Water levels simulated in the transient and projection ground-water flow models and water levels measured from March 1969 to April 2004 for four selected sites, Tooele Valley ground-water basin, Tooele County, Utah

38. Difference in water levels in model layer 2 at the end of 36-year simulation (stress period 18) between projection 1 and projection 2 of the ground-water flow model, Tooele Valley ground-water basin, Tooele County, Utah

39. Decreased discharge and increase in water removed from storage at the end of 36-year simulation (stress period 18 ) because of $(A)$ decreased recharge, projection 2 and $(B)$ increased withdrawal, projection 3 of the ground-water flow model, Tooele Valley ground-water basin, Tooele County, Utah

40. Difference in water levels in model layer 2 at the end of 36 -year simulation (stress period 18) between projection 1 and projection 3 of the ground-water flow model, Tooele Valley ground-water basin, Tooele County, Utah

41. Simulated starting locations of particles in areas of dissolved-solids concentration greater than 1,000 mg/L, Tooele Valley ground-water basin, Tooele County, Utah 
42. Simulated flow paths of particles started in areas of dissolved-solids concentration greater than $1,000 \mathrm{mg} / \mathrm{L}$, projection 1 of the ground-water flow model, Tooele Valley ground-water basin, Tooele County, Utah 76

43. Simulated backward flow paths of particles started in the area east of Erda, Tooele Valley ground-water basin, Tooele County, Utah 78

44. Simulated backward flow paths of particles started near two wells in Stansbury Park and two wells south of Grantsville City, Tooele Valley ground-water basin, Tooele County, Utah 79

45. Simulated backward flow paths of particles started along an east-west line, Tooele Valley ground-water basin, Tooele County, Utah

B1. Tooele Valley ground-water basin numerical simulation and the scoping model used to examine dewatering at the Carr Fork Service Shaft, Tooele and Salt Lake Counties, Utah

B2. The location of drain boundaries and simulated steady-state water-level contours for dewatering activities at the Carr Fork Service Shaft, Tooele and Salt Lake Counties, Utah

\section{Tables}

1. Estimated 1971-2000 average annual streamflow of eight perennial streams, Tooele Valley ground-water basin, Tooele County, Utah 7

2. Average annual ground-water budget, Tooele Valley ground-water basin, Tooele County, Utah

3. Average annual (1971-2000) precipitation, streamflow, and in-place groundwater recharge from precipitation, Tooele Valley ground-water basin, Tooele County, Utah

4. Average annual recharge from streams, 1971-2000, Tooele Valley ground-water basin, Tooele County, Utah

5. Average annual discharge for selected springs determined from measurements made during 2000-2006, Tooele Valley ground-water basin, Tooele County, Utah ........ 18

6. Evapotranspiration units and rates, Tooele Valley ground-water basin, Tooele County, Utah

7. 1971-2000 average annual conceptual recharge from precipitation and simulated recharge from precipitation, Tooele Valley ground-water basin, Tooele County, Utah

8. Annual recharge from precipitation, Tooele Valley ground-water basin, Tooele County, Utah

9. Conceptual ground-water budget for 1968 and ground-water budget simulated in the steady-state period of the ground-water flow model, Tooele Valley ground-water basin, Tooele County, Utah

10. Conceptual ground-water budget for 2003 and ground-water budget simulated in stress period 36 of the transient ground-water flow model, Tooele Valley ground-water basin, Tooele County, Utah

11. Observations with the highest one-percent scaled sensitivity in stress period 36 in layer 2 to selected model parameters, Tooele Valley ground-water basin, Tooele County, Utah

12. Ground-water budget for model simulations, Tooele Valley ground-water basin, Tooele County, Utah 
13. Highly correlated parameters in the ground-water flow model, Tooele Valley ground-water basin, Tooele County, Utah

C1. U.S. Geological Survey site identification number, local well number, and use of data for selected wells with water levels and water quality, Tooele Valley groundwater basin, Tooele County, Utah

C2. Well name and water-level use for selected Tooele Army Depot wells with water-level data, Tooele Valley ground-water basin, Tooele County, Utah

C3. Discharge of selected springs from 2003 to 2005, Tooele Valley ground-water basin, Tooele County, Utah

C4. $\delta^{2} \mathrm{H}$ and $\delta^{18} \mathrm{O}$ values in ground water and springs from selected sites, Tooele Valley ground-water basin, Tooele County, Utah

C5. Dissolved gas, tritiogenic helium-3, and tritium concentrations, and apparent age for ground-water samples collected from selected wells, Tooele Valley ground-water basin, Tooele County, Utah

C6. Description of model parameters, ground-water flow model, Tooele Valley ground-water basin, Tooele County, Utah 


\section{Conversion Factors, Datums, and Abbreviated Water-Quality Units}

\begin{tabular}{|c|c|c|}
\hline Multiply & By & To obtain \\
\hline \multicolumn{3}{|c|}{ Length } \\
\hline foot $(\mathrm{ft})$ & 0.3048 & meter $(\mathrm{m})$ \\
\hline inch (in.) & 2.54 & centimeter $(\mathrm{cm})$ \\
\hline inch (in.) & 25.4 & millimeter $(\mathrm{mm})$ \\
\hline mile (mi) & 1.609 & kilometer $(\mathrm{km})$ \\
\hline \multicolumn{3}{|c|}{ Area } \\
\hline acre & 4,047 & square meter $\left(\mathrm{m}^{2}\right)$ \\
\hline acre & 0.4047 & square hectometer $\left(\mathrm{hm}^{2}\right)$ \\
\hline acre & 0.004047 & square kilometer $\left(\mathrm{km}^{2}\right)$ \\
\hline square mile $\left(\mathrm{mi}^{2}\right)$ & 2.590 & square kilometer $\left(\mathrm{km}^{2}\right)$ \\
\hline \multicolumn{3}{|c|}{ Volume } \\
\hline acre-foot per year (acre-ft/yr) & 1,233 & cubic meter per year $\left(\mathrm{m}^{3} / \mathrm{yr}\right)$ \\
\hline \multicolumn{3}{|c|}{ Flow rate, velocity, and hydraulic conductivity } \\
\hline gallons per minute (gpm) & 0.06309 & liters per second $(\mathrm{L} / \mathrm{s})$ \\
\hline acre-foot per year (acre-ft/yr) & 1,233 & cubic meter per year $\left(\mathrm{m}^{3} / \mathrm{yr}\right)$ \\
\hline acre-foot per year (acre-ft/yr) & 0.001233 & cubic hectometer per year $\left(\mathrm{hm}^{3} / \mathrm{yr}\right)$ \\
\hline cubic foot per second $\left(\mathrm{ft}^{3} / \mathrm{s}\right)$ & 0.02832 & cubic meter per second $\left(\mathrm{m}^{3} / \mathrm{s}\right)$ \\
\hline foot per day $(\mathrm{ft} / \mathrm{d})$ & 0.3048 & meter per day $(\mathrm{m} / \mathrm{d})$ \\
\hline foot per mile ( $\mathrm{ft} / \mathrm{mi})$ & 0.1894 & meter per kilometer $(\mathrm{m} / \mathrm{km})$ \\
\hline foot per year (ft/yr) & 0.3048 & meter per year $(\mathrm{m} / \mathrm{yr})$ \\
\hline foot squared per day $\left(\mathrm{ft}^{2} / \mathrm{d}\right)$ & 0.09290 & meter squared per year $\left(\mathrm{m}^{2} / \mathrm{yr}\right)$ \\
\hline inch per year (in./yr) & 25.4 & millimeter per year (mm/yr) \\
\hline
\end{tabular}

Temperature in degrees Celsius $\left({ }^{\circ} \mathrm{C}\right)$ may be converted to degrees Fahrenheit $\left({ }^{\circ} \mathrm{F}\right)$ as follows:

${ }^{\circ} \mathrm{F}=\left(1.8 \mathrm{x}^{\circ} \mathrm{C}\right)+32$.

Temperature in degrees Fahrenheit $\left({ }^{\circ} \mathrm{F}\right)$ may be converted to degrees Celsius $\left({ }^{\circ} \mathrm{C}\right)$ as follows:

${ }^{\circ} \mathrm{C}=\left({ }^{\circ} \mathrm{F}-32\right) / 1.8$.

Vertical coordinate information is referenced to the North American Vertical Datum of 1929 (NAVD 29); horizontal coordinate information is referenced to the North American Datum of 1983 (NAD 83). Altitude, as used in this report, refers to distance above the vertical datum.

Specific conductance is given in microsiemens per centimeter at 25 degrees Celsius $(\mu \mathrm{S} / \mathrm{cm}$ at $\left.25^{\circ} \mathrm{C}\right)$.

Chemical concentration in water generally is reported in milligrams per liter $(\mathrm{mg} / \mathrm{L})$ or micrograms per liter $(\mu \mathrm{g} / \mathrm{L})$. These units express the concentration of chemical constituents in solution as weight (grams) of solute per unit volume (liter) of water. A liter of water is assumed to weigh 1 kilogram. For concentrations less than $7,000 \mathrm{mg} / \mathrm{L}$, the numerical value in milligrams per liter is equivalent to concentration expressed as parts per million. Exceptions to this assumption include brines and water at high temperatures, both of which result in changes to the density of water.

Concentrations of dissolved gases are reported in cubic centimeters of gas at standard temperature and pressure per gram of water $\left(\mathrm{cm}^{3} \mathrm{STP} / \mathrm{g}\right)$. Tritium concentration is reported in tritium units (TU). 


\section{Abbreviations and Acronyms Used in the Text}

$\begin{array}{ll}\text { BCM } & \text { Basin Characterization Model } \\ \text { d } & \text { day } \\ \text { DEM } & \text { Digital Elevation Model } \\ \text { GMWL } & \text { Global Meteoric Water Line } \\ \text { gpm } & \text { gallons per minute } \\ \text { hr } & \text { hour } \\ \text { HFB } & \text { Horizontal-Flow Barrier } \\ \text { m } & \text { meter } \\ \text { TEAD } & \text { Tooele Army Depot } \\ \text { TU } & \text { tritium unit } \\ \text { USGS } & \text { U.S. Geological Survey } \\ \text { yr } & \text { year }\end{array}$




\title{
Hydrology and Simulation of Ground-Water Flow in the Tooele Valley Ground-Water Basin, Tooele County, Utah
}

\author{
By Bernard J. Stolp and Lynette E. Brooks
}

\section{Abstract}

Ground water is the sole source of drinking water within Tooele Valley. Transition from agriculture to residential land and water use necessitates additional understanding of water resources. The ground-water basin is conceptualized as a single interconnected hydrologic system consisting of the consolidated-rock mountains and adjoining unconsolidated basin-fill valleys. Within the basin fill, unconfined conditions exist along the valley margins and confined conditions exist in the central areas of the valleys. Transmissivity of the unconsolidated basin-fill aquifer ranges from 1,000 to 270,000 square feet per day. Within the consolidated rock of the mountains, ground-water flow largely is unconfined, though variability in geologic structure, stratigraphy, and lithology has created some areas where ground-water flow is confined. Hydraulic conductivity of the consolidated rock ranges from 0.003 to 100 feet per day.

Ground water within the basin generally moves from the mountains toward the central and northern areas of Tooele Valley. Steep hydraulic gradients exist at Tooele Army Depot and near Erda. The estimated average annual ground-water recharge within the basin is 82,000 acre-feet per year. The primary source of recharge is precipitation in the mountains; other sources of recharge are irrigation water and streams. Recharge from precipitation was determined using the Basin Characterization Model. Estimated average annual groundwater discharge within the basin is 84,000 acre-feet per year. Discharge is to wells, springs, and drains, and by evapotranspiration. Water levels at wells within the basin indicate periods of increased recharge during 1983-84 and 1996-2000. During these periods annual precipitation at Tooele City exceeded the 1971-2000 annual average for consecutive years.

The water with the lowest dissolved-solids concentrations exists in the mountain areas where most of the groundwater recharge occurs. The principal dissolved constituents are calcium and bicarbonate. Dissolved-solids concentration increases in the central and northern parts of Tooele Valley, at the distal ends of the ground-water flow paths. Increased concentration is due mainly to greater amounts of sodium and chloride. Deuterium and oxygen-18 values indicate water recharged primarily from precipitation occurs throughout the ground-water basin. Ground water with the highest percentage of recharge from irrigation exists along the eastern margin of Tooele Valley, indicating negligible recharge from the adjacent consolidated rock. Tritium and tritiogenic helium-3 concentrations indicate modern water exists along the flow paths originating in the Oquirrh Mountains between Settlement and Pass Canyons and extending between the steep hydraulic gradient areas at Tooele Army Depot and Erda. Pre-modern water exists in areas east of Erda and near Stansbury Park. Using the change in tritium along the flow paths originating in the Oquirrh Mountains, a first-order estimate of average linear ground-water velocity for the general area is roughly 2 to 5 feet per day.

A numerical ground-water flow model was developed to simulate ground-water flow in the Tooele Valley ground-water basin and to test the conceptual understanding of the groundwater system. Simulating consolidated rock allows recharge and withdrawal from wells in or near consolidated rock to be simulated more accurately. In general, the model accurately simulates water levels and water-level fluctuations and can be considered an adequate tool to help determine the valley-wide effects on water levels of additional ground-water withdrawal and changes in water use. The simulated increase in storage during a projection simulation using 2003 withdrawal rates and average recharge indicates that repeated years of average precipitation and recharge conditions do not completely restore the system after multiple years of below-normal precipitation. In the similar case where precipitation is 90 percent of average, water levels throughout most of Tooele Valley are projected to be as much as 50 feet lower. Water levels are projected to be at least 10 feet lower basin wide, and as much as 260 feet lower over most of the southeastern part of Tooele Valley, due to projected increases in well withdrawals. Particle tracking indicates that projected reduced recharge or increased withdrawals do not change the direction of ground-water flow from areas of high dissolved-solids concentration.

\section{Introduction}

Tooele Valley is located about $30 \mathrm{mi}$ west of the Wasatch Front, the major urbanized area of Utah. Proximity to the Wasatch Front has led to rapid population growth and ground water is the sole source of drinking water within the valley. 
Both land and water resources that traditionally have been used for agricultural purposes are now being converted to residential and municipal use, and this transition will affect Tooele Valley water resources. Management of water resources under these changing conditions requires additional understanding of the spatial distribution of water resources, and specifically the quantity, quality, and sustainability of ground water. To improve the understanding of water resources in Tooele Valley, the U.S. Geological Survey (USGS), in cooperation with Tooele County, conducted a hydrologic study of the areas that contribute recharge to the unconsolidated basin fill in Tooele Valley (fig. 1). For purposes of this report, the contributing area is referred to as the "Tooele Valley ground-water basin." The study period extended from 2003 to 2006 . Plate 1 shows hydrologic-data sites within the study area. The numbering system used for hydrologic-data sites in Utah is shown in figure 2.

The principal objectives of this study of the Tooele Valley ground-water basin were to gain additional understanding of (1) ground-water recharge and its distribution in the mountain areas, (2) changing ground-water withdrawals and resulting effects on water levels and water quality, (3) ground-water movement and residence times, and (4) ground-water discharge to wetland areas of northern Tooele Valley. A threedimensional ground-water flow model that simulates flow in the unconsolidated basin fill and consolidated rock was constructed as both a tool for evaluation and a synthesis of current conceptual understanding. The model domain encompasses the entire area of the Tooele Valley ground-water basin.

\section{Purpose and Scope}

The purpose of this report is to present a conceptual model and water budget of the Tooele Valley ground-water basin and to describe a new three-dimensional numerical ground-water flow model of the basin developed as part of the study. The results presented in this report represent an incremental improvement in understanding the hydrologic concepts first presented by Carpenter (1913) and refined by Thomas (1946), Gates (1965), Razem and Steiger (1981), and Lambert and Stolp (1999). Improvements include a more comprehensive description of ground-water recharge using a distributed net infiltration approach and a more detailed description of ground-water movement and residence times. Major components of ground-water discharge including evapotranspiration, flowing wells, and large springs were re-estimated using current land-use information, updated knowledge of water use by natural vegetation, and direct discharge measurements. Environmental tracers were used to assess general aquifer characteristics, and recharge sources and processes. These concepts, quantifications, and constraints were collectively synthesized into a transient numerical simulation of groundwater flow for the basin. The simulation was used as a tool to evaluate the effects of several ground-water withdrawal scenarios on regional water levels, water quality, and groundwater movement.

\section{Acknowledgments}

A regional scale ground-water study is not possible without the cooperation of individual well owners. Specific thanks go to Tooele City Division of Public Works for access to municipal wells; to Tooele Army Depot (TEAD) for waterlevel, geophysical, and general flow-system information; and to private landowners in Tooele Valley and Rush Valley for access to wetland areas, springs, and wells. Tooele County facilitated this study by working with a number of public and private entities including Tooele City; Utah Department of Natural Resources, Division of Water Rights; Utah Department of Natural Resources, Division of Water Resources; Grantsville City; Kennecott Land; Oquirrh Mountain Water Company; Stansbury Park Improvement District; and Stockton City.

\section{Physical Characteristics of the Study Area}

The Tooele Valley ground-water basin is located in the Basin and Range Physiographic Province (Fenneman, 1931). The term "ground-water basin" refers to the surface area that encompasses all the recharge and discharge areas of the underlying aquifer system. The Tooele Valley ground-water basin extends from the ground-water divide in Rush Valley (Hood and others, 1969) north along the topographic divides of the Stansbury and Oquirrh Mountains and terminates at Great Salt Lake (fig. 1). Altitudes in the basin range from about $4,200 \mathrm{ft}$ near Great Salt Lake to over 10,000 ft along the topographic divides of the Oquirrh and Stansbury Mountains. The largest expanse of mountainous area exists southeast of Tooele City.

\section{Land Use}

Land use within the Tooele Valley ground-water basin includes the military operations of TEAD; irrigated farmland, pasture, and grazing; incorporated and unincorporated residential areas; industrial and commercial areas; and mining. The mountainous areas of the ground-water basin are mostly undeveloped, and the primary land uses are recreation, mining, and grazing. Northern Tooele Valley contains large areas of wetlands. In the eastern part of Tooele Valley land use is changing from agricultural to low- and high-density residential. High-density development is occurring at Tooele City, Grantsville City, Stansbury Park, and Lake Point. Lower density development is taking place in the unincorporated areas of Tooele County that separate the higher density areas.

\section{Precipitation}

The average annual precipitation (1971-2000) in the Tooele Valley ground-water basin varies from about 12 to 14 in. in the lower valley areas to about $50 \mathrm{in}$. at the highest altitudes of the surrounding mountains. The spatial distribution of precipitation across the basin is directly related to altitude and is shown in figure 3. Average annual precipitation at Tooele City through the 4-yr study period (2003-06) was $19.1 \mathrm{in}$./yr. 


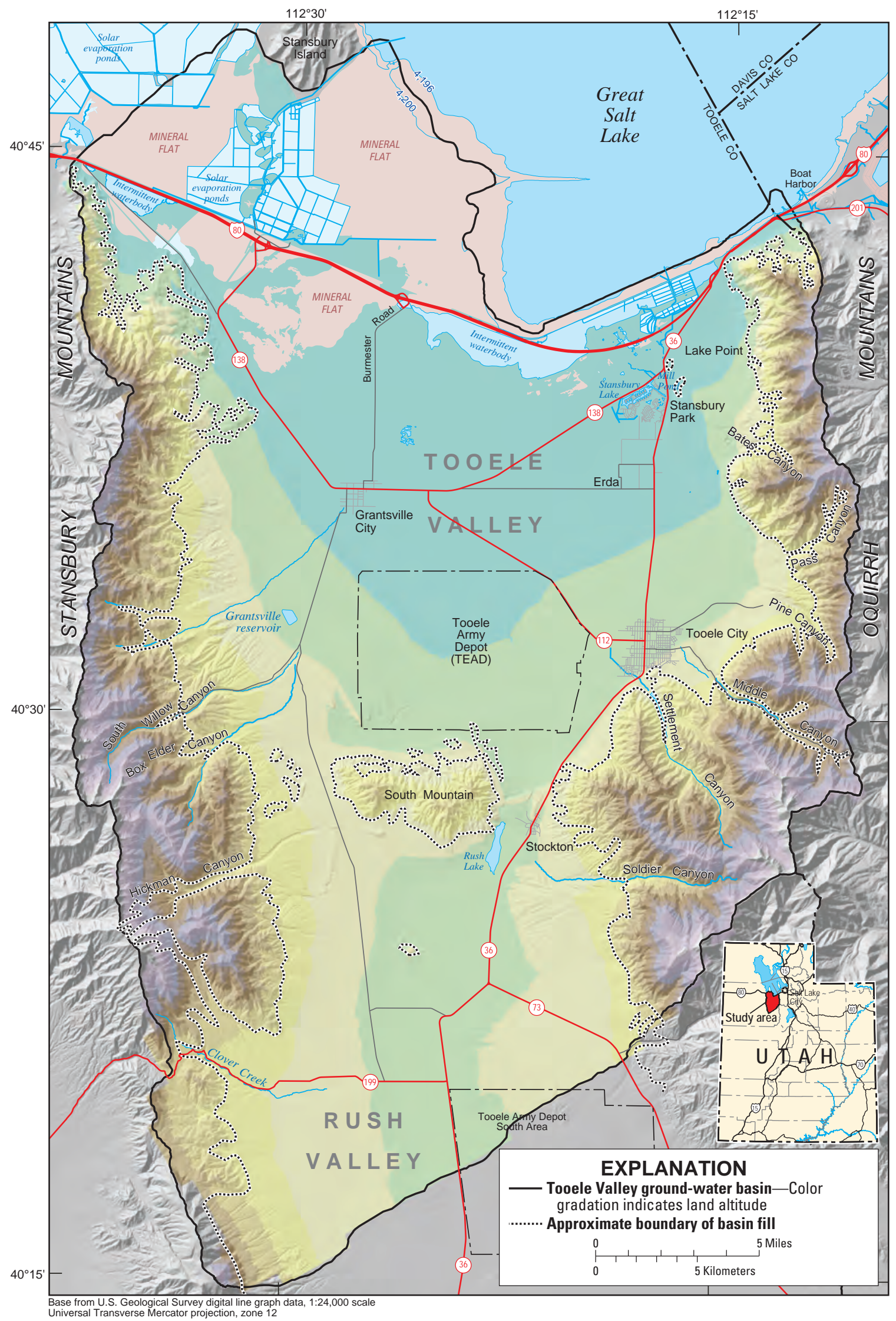

Figure 1. Tooele Valley ground-water basin, Tooele County, Utah. 

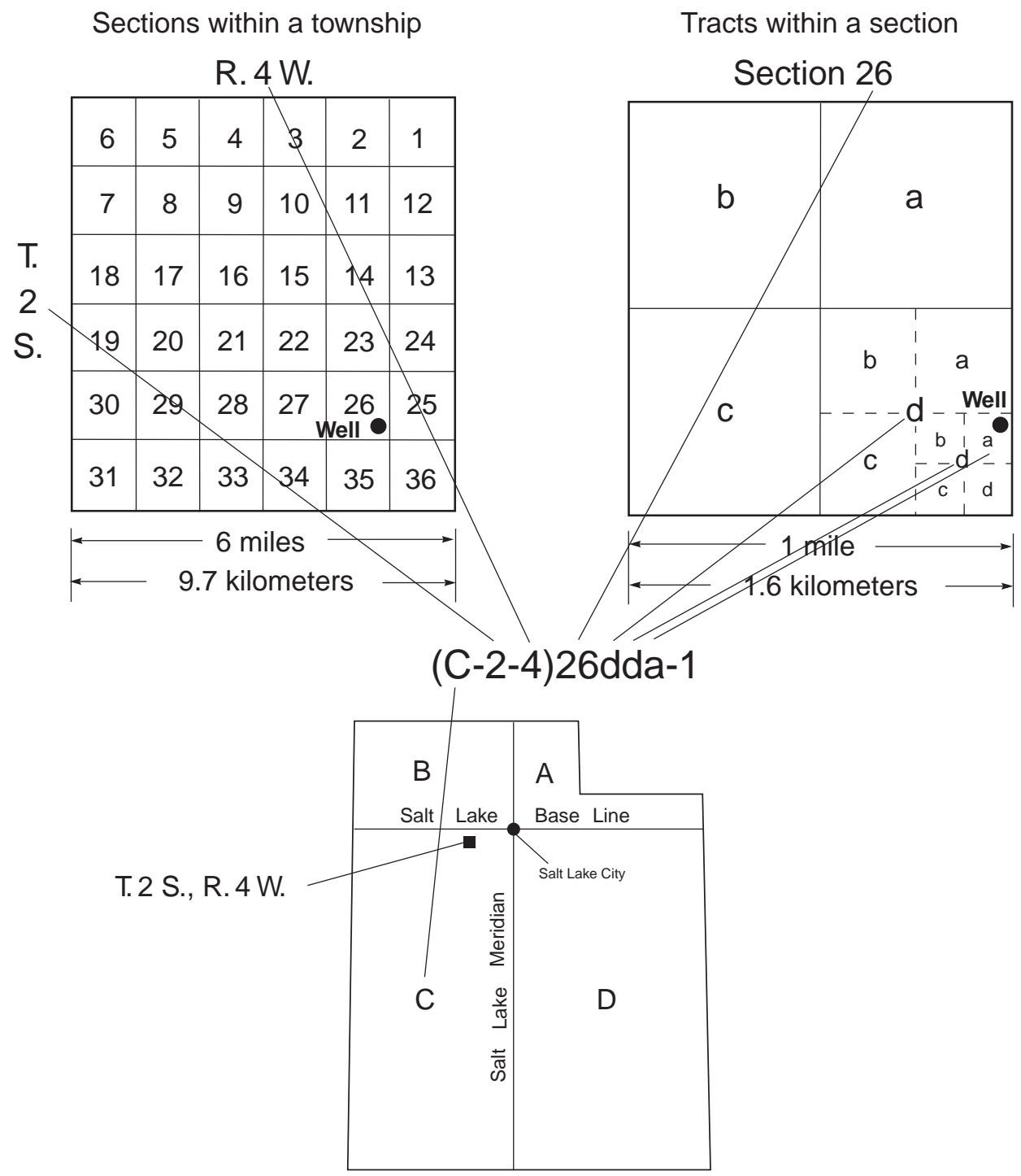

The system of numbering wells, springs, and other hydrologic-data sites in Utah is based on the cadastral land-survey system of the U.S. Government. The number, in addition to designating the site, describes its position in the land net. The land-survey system divides the State of Utah into four quadrants by the Salt Lake Base Line and the Salt Lake Meridian. These quadrants are designated by the uppercase letters A, B, C, and D which indicate, respectively, the northeast, northwest, southwest, and southeast quadrants. Numbers that designate the township and range (in that order) follow the quadrant letter, and all three are enclosed in parentheses. The number after the parentheses indicates the section and is followed by three lowercase letters that indicate the quarter section, the quarter-quarter section, and the quarter-quarterquarter section — generally 10 acres for regular sections ${ }^{1}$. The lowercase letters a, b, c, and d indicate, respectively, the northeast, northwest, southwest, and southeast quarters of each subdivision. The number after the letters is the serial number of the well or spring within the 10 -acre plot. The letter $\mathrm{S}$ preceding the serial number denotes a spring. Thus, (C-2-4)26dda-1 designates the first well constructed or visited in the NE 1/4 of the SE 1/4, of the SE 1/4, Sec. 26, T.2 S., R.4 W. The capital letter C indicates that the township is south of the Salt Lake Base Line and the range is west of the Salt Lake Meridian.

${ }^{1} \mathrm{~A}$ Ithough the basic land unit, the section, is theoretically 1 square mile, many sections are irregular. Such sections are subdivided into 10-acre tracts, generally beginning at the southeast corner, and the surplus or shortage is taken up in the tracts along the north and west sides of the section.

Figure 2. Numbering system for hydrologic-data sites in Utah. 


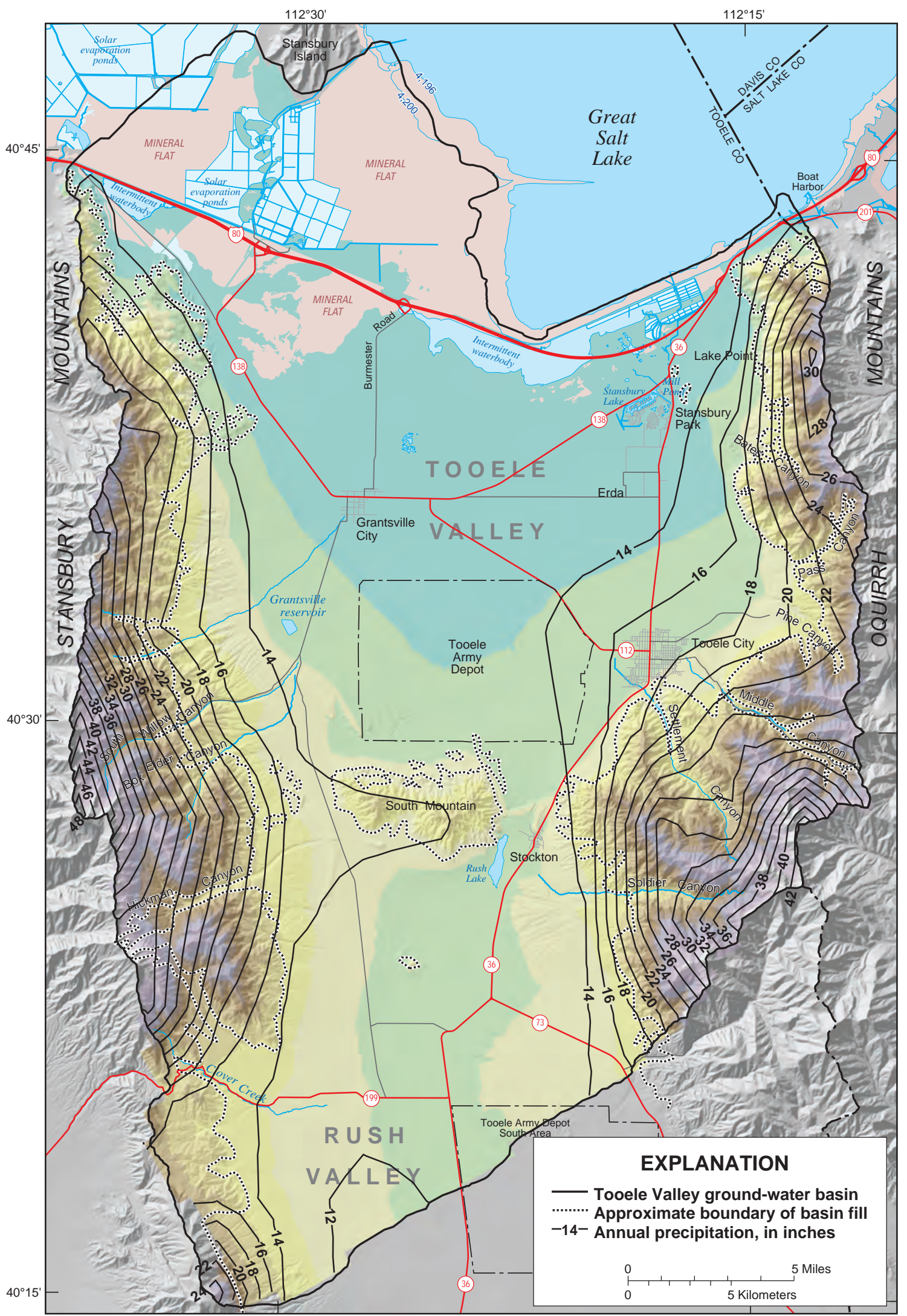

Base from U.S. Geological Survey digital line graph data, 1:24,000 scale
Universal Transverse Mercator projection, zone 12

Figure 3. Average annual precipitation for the period 1971-2000, Tooele Valley ground-water basin, Tooele County, Utah. 


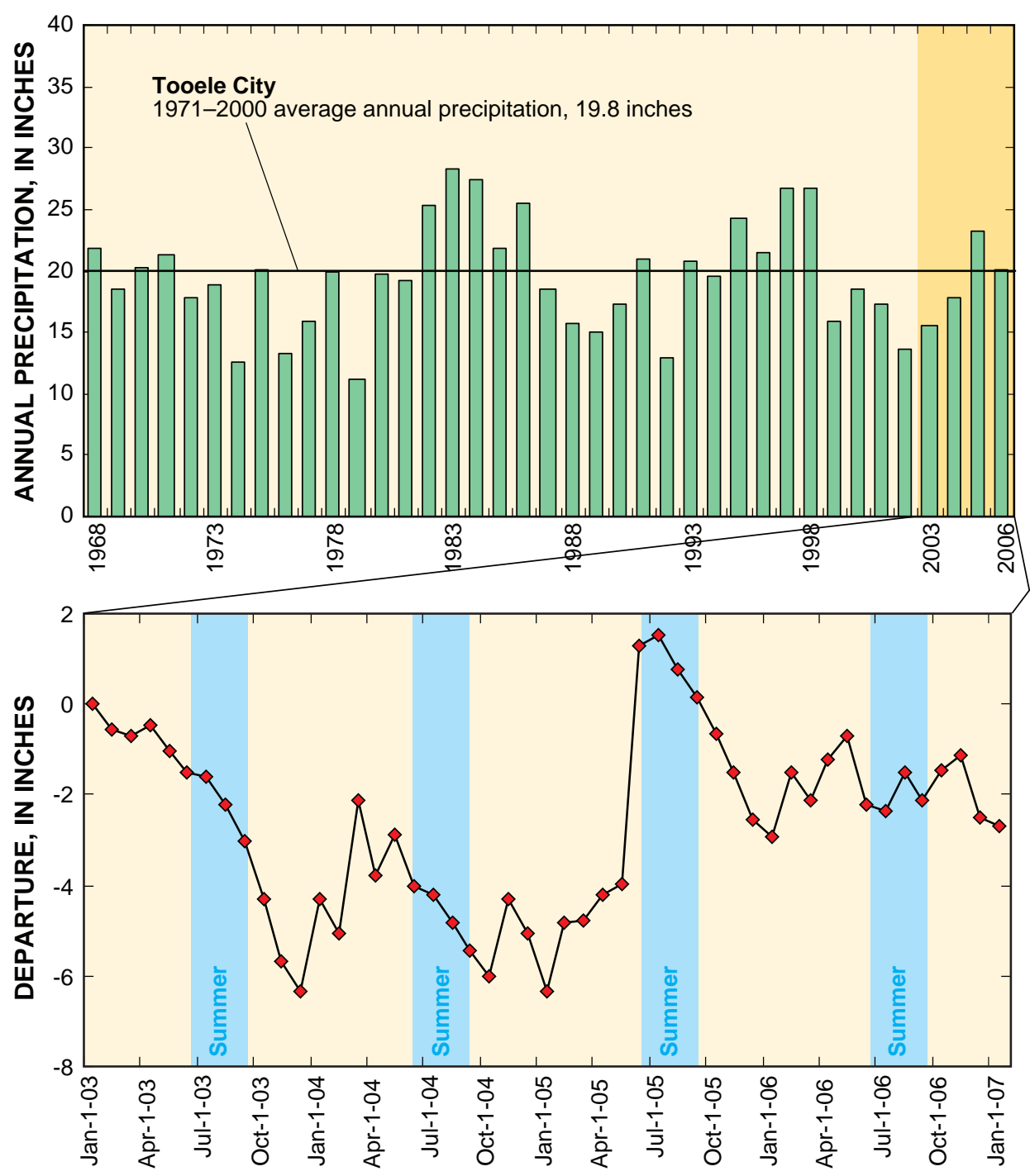

Figure 4. Annual precipitation at Tooele City from 1968 to 2006, and cumulative departure from the 1971-2000 monthly average precipitation at Tooele City from 2003 to 2006, Tooele Valley ground-water basin, Tooele County, Utah.

This is $0.7 \mathrm{in} . / \mathrm{yr}$ less than the 1971-2000 average. Precipitation was generally below average during the summer months; May 2005 was unusually wet with precipitation about 5 in. above average (fig. 4). The cumulative effects of these departures resulted in a total deficit of about 3 in. over the duration of the study.

\section{Streamflow}

There are eight perennial streams in the Tooele Valley ground-water basin with estimated average annual streamflow greater than $500 \mathrm{acre}-\mathrm{ft} / \mathrm{yr}$ (table 1). The streams originate in the Oquirrh and Stansbury Mountains. The major sources of streamflow are runoff and baseflow with snowmelt being the largest component of runoff. Total streamflow for the perennial streams was determined from the long-term streamflow information for South Willow Creek and short-term and miscellaneous streamflow information for the other streams (table
1). Baseflow was estimated by examining average streamflow during low-flow months (generally September-April) and by making minor adjustments on the basis of individual stream and drainage basin characteristics. Baseflow originates as direct inflow of ground water and(or) spring flow to the stream, and is the sole source of stream water during late summer and fall when the snow pack has completely melted.

The 1971-2000 average annual streamflow (baseflow plus runoff) for South Willow Creek in the Stansbury Mountains (pl. 1) was determined directly from the USGS streamflow gaging station that has operated continuously from 1963 to 2006. The 1971-2000 average annual streamflow is 5,100 acre-ft (table 1 and fig. 5). The drainage area above the gaging station is $4.2 \mathrm{mi}^{2}$. Using the long-term South Willow Creek record, 1971-2000 average annual streamflow was estimated for the other perennial streams. The estimation was done by normalizing the short-term and miscellaneous streamflow information to South Willow Creek. For example, North 
Table 1. Estimated 1971-2000 average annual streamflow of eight perennial streams, Tooele Valley ground-water basin, Tooele County, Utah.

[All flows in acre-feet per year, rounded]

\begin{tabular}{|c|c|c|c|c|c|}
\hline Stream & Baseflow & Streamflow runoff & Total & Period of record & Station number \\
\hline \multicolumn{6}{|c|}{ Tooele Valley } \\
\hline North Willow Creek & 1,200 & 2,800 & 4,000 & 1979-1991 & 10172805 \\
\hline Box Elder Creek & 200 & 400 & 600 & $1987-1993$ & 10172795 \\
\hline Settlement Creek & 3,000 & 4,200 & 7,200 & 1989-1995 & 10172791 \\
\hline Middle Canyon Creek & 600 & 2,600 & 3,200 & 1984-1986 & ${ }^{1} 10172794$ \\
\hline Total Tooele Valley & 7,700 & 13,300 & 21,000 & & \\
\hline \multicolumn{6}{|c|}{ Northern Rush Valley } \\
\hline Clover Creek & 1,400 & 2,200 & 3,600 & 1984-2000 & 10172765 \\
\hline Soldier Creek & 700 & 2,000 & 2,700 & $\begin{array}{l}{ }^{2} \text { Miscellaneous } \\
\text { measurements }\end{array}$ & \\
\hline Total Northern Rush Valley & 2,100 & 4,200 & 6,300 & & \\
\hline
\end{tabular}

${ }^{1}$ Estimate of streamflow is for site (C-3-4)35aba on the basis of streamflow gaging station records adjusted to account for stream-channel losses (Stolp, 1994, p. 12) and miscellaneous streamflow estimates listed in Stolp (1994, tables 4 and 6).

${ }^{2}$ Miscellaneous measurements from Stolp (1994, table 7) for location (C-4-4)33add.

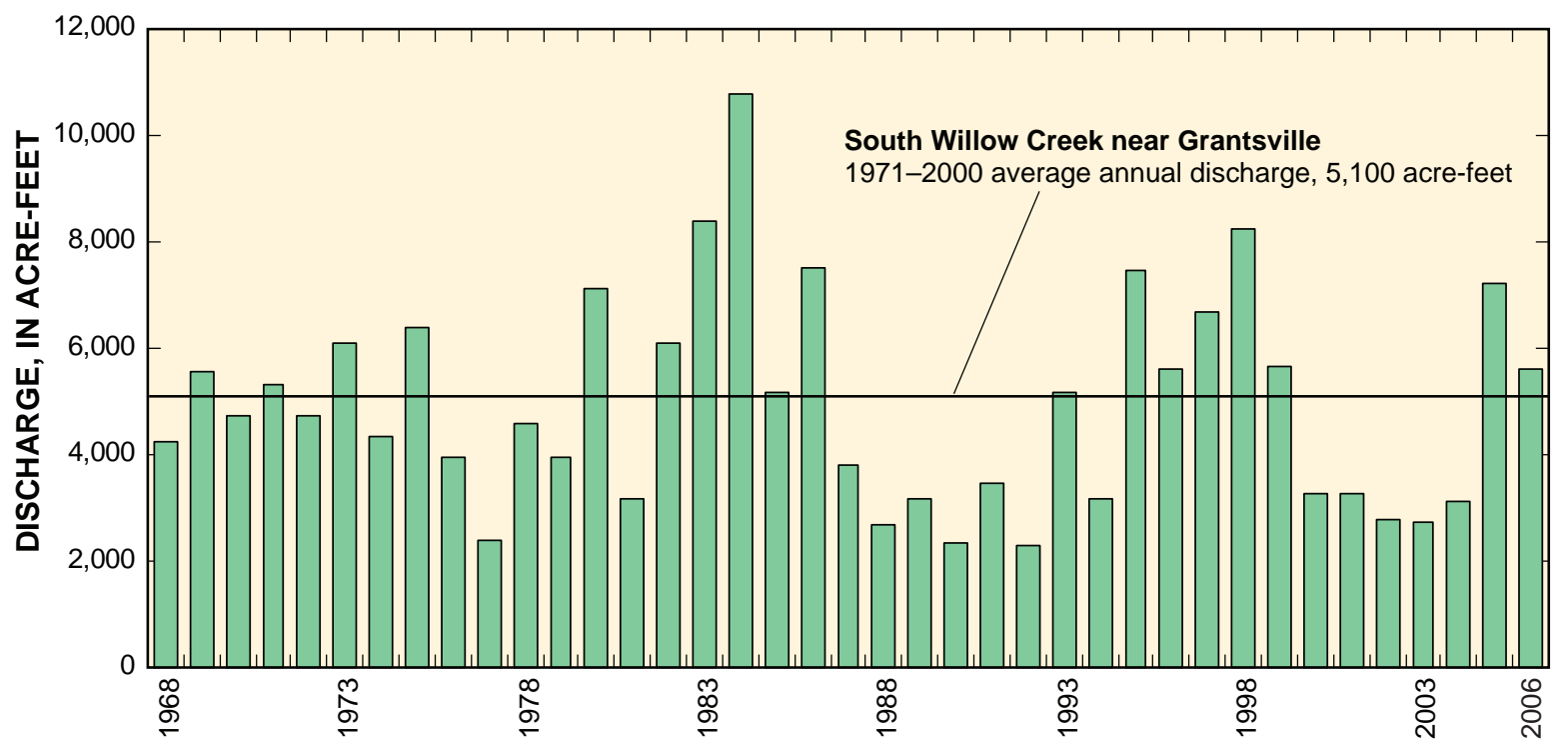

Figure 5. Annual streamflow of South Willow Creek from 1971 to 2004, Tooele Valley ground-water basin, Tooele County, Utah.

Willow Creek streamflow was measured from 1979 to 1991. During that time, streamflow in North Willow Creek was 78 percent of the flow in South Willow Creek. Using that ratio, the 1971-2000 average annual streamflow for North Willow Creek was scaled at 78 percent of the South Willow Creek average $(5,100 \times 0.78=4,000$ acre-ft). No streamflow gaging station was ever established on Soldier Creek; therefore, the 1971-2000 average was determined solely from miscellaneous streamflow measurements adjusted for the point where the stream crosses the consolidated-rock/basin-fill boundary. (Stolp, 1994, table 7).

\section{Geology}

Most of the consolidated rock exposed in the South, Stansbury, and Oquirrh Mountains was deposited about 570 to 290 million years ago (the Paleozoic Era) along the eastern margins of an ancient ocean. The eastern margins of the ocean existed in what is now the western area of Utah. Beginning around 290 million years ago, these relatively flat strata started to become deformed by continental scale compressional forces exerted from the west. Compression and mountain building intensified from 140 to 90 million years ago. This created a series of folds and thrust faults (similar to pushing the edge of a rug) that generally have northwest to southeast trending axes (Biek, 2005). Mountain building was followed by relaxation 
Hydrology and Simulation of Ground-Water Flow in the Tooele Valley Ground-Water Basin, Tooele County, Utah

of compressional forces, a period of volcanic activity, and the eventual onset of extensional forces. In localized areas, igneous rocks have intruded through the consolidated rocks and formed dikes, sills, and ore deposits in the subsurface.

Extensional forces have created the current topography. Extension produced normal faulting in the consolidated rock (Moore and Sorensen, 1979) creating down-dropped grabens (Tooele and Rush Valleys) separated by elevated horsts (Stansbury and Oquirrh Mountains). Outcrops and geophysical data indicate that within the valley-scale grabens is an irregular surface that includes a complex collection of smaller-scale ridges and troughs (ERTEC, 1982; Asch, 2005). Tooele and Rush Valleys are the depositional basins for the unconsolidated material that has eroded from the surrounding mountains. The unconsolidated basin fill consists of alluvial-fan, colluvial, and lacustrine deposits. Most recently, Quaternary-age lakes have reworked the unconsolidated basin fill.

\section{Hydrology of the Ground-Water Basin}

The Tooele Valley ground-water basin is conceptualized as a single interconnected hydrologic system consisting of consolidated rock in the mountains and adjoining unconsolidated basin fill in the valleys. Most ground-water recharge occurs in the mountains and along streams where they flow out of the mountains. Discharge occurs to large springs, wetlands, plants via evapotranspiration, and wells. Wells withdraw water for municipal, residential, and agricultural use.

The edge of the ground-water basin corresponds to hydrologic boundaries. On the far side of these boundaries, ground water moves away from the basin; on the near side ground water moves into the basin. A hydrologic boundary does not necessarily mean hydraulic isolation; the direction of movement, and hence location, of a boundary can change depending on local patterns and amounts of ground-water recharge and discharge. In the Oquirrh and Stansbury Mountains, the basin boundary is estimated to coincide with the surface-water divides. The boundary in Rush Valley corresponds to a ground-water divide delineated from water-level data; there is no matching surface-water divide. The northern boundary of the ground-water basin is the shoreline of Great Salt Lake. Lake altitude, salinity, and the predominance of fine-grained lacustrine deposits create the northern terminal end of the basin.

\section{Hydrogeology}

Ground water generally follows topography, moving from the higher altitude mountains into the adjacent lower altitude valleys and northward toward Great Salt Lake (fig. 1). Geologic features (structure, stratigraphy, and lithology), climatic conditions, and human influences (stream diversions and ground-water withdrawals) control the details of movement, recharge, and discharge.

\section{Unconsolidated Basin Fill}

Erosion from the surrounding mountains is the source of the unconsolidated basin fill. Along the valley margins and at canyon mouths, the unconsolidated deposits are composed of alluvial fan and colluvial deposits. These deposits are poorly sorted coarse gravel and sand with no defined layering. Toward the distal end of the alluvial fans, grain size decreases and sorting increases. In the center of the valley, lacustrine deposits dominate. These deposits have a finer average grain size and a greater degree of layering. Numerous cycles of inundation and desiccation of Quaternary-age lakes, most notably Lake Bonneville, further amalgamated this heterogeneous mixture of gravel, sand, silt, and clay. During periods of inundation, the lake environment reworked alluvial fans to create spits and bars. Deltas were formed where streams entered the lakes. As lakes dried, delta features were dissected by streams, and materials were transported and redeposited. Another result of cyclical lake levels is that alluvial fan deposits have undergone some amount of compaction and cementation.

\section{Consolidated Rock}

Consolidated rocks occur in the surrounding mountains and underlie all of Tooele and Rush Valleys. The consolidated rock underlying the valleys includes a complex collection of ridges and troughs (ERTEC, 1982; Asch, 2005). This buried topography creates variability in the thickness and characteristics of the overlying unconsolidated basin fill. Consolidated rocks are composed mainly of limestone and quartzite and include calcareous and silty limestone, dolomite, shale, and sandstone of the Oquirrh Formation. These materials are extensively folded, faulted, and eroded. In localized areas, igneous rocks have intruded through the sedimentary and meta-sedimentary rocks to the surface and formed dikes, sills, and ore deposits in the subsurface.

\section{Ground-Water Conditions}

Within the unconsolidated basin fill, ground water occurs under both confined and unconfined conditions. In general, unconfined or water-table conditions exist along the valley margins within alluvial fan and colluvial deposits and confined conditions exist in the central areas of the valleys. Confined ground-water flow conditions exist generally where lacustrine deposits have created zones of permeable material mixed with discontinuous to continuous layers of less permeable clay or silt. Clay layers reduce the vertical hydraulic conductivity to create confined flow conditions in the deeper unconsolidated basin fill. Ground-water flow in the unconsolidated basin fill above the clay and silt lenses is unconfined.

Most of the ground-water flow in the unconsolidated basin fill probably exists at depths of less than $1,000 \mathrm{ft}$ below the water table. Depending on location, this depth corresponds to either the gradational boundary with the less-permeable 
Tertiary-age Salt Lake Formation (Lambert and Stolp, 1999 , p. 5) or the depth at which compaction significantly reduces permeability. Referencing depth of ground-water flow to the water table incorporates differential compaction. Along the valley margins, where water levels average $500 \mathrm{ft}$ below land surface, the vertical flow limit is at about $1,500 \mathrm{ft}$ below land surface. The basin fill along the margins is generally coarse grained (less compactable), and nearest the mountain front is less than $1,500 \mathrm{ft}$ thick. In that case, some underlying consolidated rock is incorporated into the vertical flow limit. In central areas (where fine-grained, more compressible fill is prevalent), the water table is at or near land surface and the vertical flow limit is estimated at about $1,000 \mathrm{ft}$ below land surface.

For the consolidated rock in the mountain areas, most ground-water flow is unconfined, though variability in geologic structure and lithology likely has created areas where ground-water flow is confined. Areas of perched ground water likely also exist. Hydraulic gradients are variable, but generally mirror topography. This concept is supported by the fact that most ground-water discharge occurs along the canyon bottoms to streams and springs; there is limited discharge to isolated hillside springs. Gradient variability can be created by folding or faulting of lower-permeability stratigraphic units, and the spatial variability of recharge. Alternating steep and flat gradients have been observed in the consolidated rock west of Tooele City. Water-level data from over 200 monitoring wells have made detailed mapping of the hydraulic gradient in this area possible (Kleinfelder Inc., 2003).

\section{Aquifer Properties}

Aquifer properties describe the capability of the groundwater system to transmit and store water. Broad spatial trends in aquifer properties can be estimated from depositional environments, hydraulic gradients, and information about groundwater flow and velocities. Localized properties are determined from pumping at a specific well and observing water-level response. Pumping and water levels are a direct measurement of conductivity and storage for a portion of the aquifer near the well. Results from individual wells tend to exaggerate variability within an aquifer, whereas indirect determinations of aquifer properties tend to average variability. Previous reports that discuss aquifer properties of the Tooele Valley ground-water basin include Thomas (1946), Gates (1965, table 3), Razem and Steiger (1981, table 4), Stolp (1994, table 8), Steiger and Lowe (1997), Lambert and Stolp (1999, p. 9), and U.S. Army Corps of Engineers (2006, p. 13).

\section{Unconsolidated Basin Fill}

Grain size and sorting are important factors controlling aquifer properties of the unconsolidated basin fill. Near the mountains and along the valley margins, coarse-grained material predominates; in the central and northern valley areas, deposits are finer grained (Steiger and Lowe, 1997). As a result, ground-water flow tends to be unconfined to semiconfined along the margins and confined in the central valley areas.

The presence of coarse material does not always translate to increased hydraulic conductivity. Steep hydraulic gradients and data from well drilling indicate less permeable conditions exist at and near the mountain front. Specifically, the poorly sorted, partially cemented fanglomerate Harker Formation (Tooker, 1980) yields only small amounts of water to wells. Numerous large-yielding water wells are located at intermediate distances (1 to $2 \mathrm{mi}$ ) from the mountain front. Higher permeabilities likely are due to reworking of sediments associated with Quaternary-age lakes and related wave action and alongshore currents.

Analysis of single- and multiple-well test data (from wells completed in the unconsolidated basin fill in Tooele Valley) resulted in transmissivity values that range from 1,000 to $270,000 \mathrm{ft}^{2} / \mathrm{d}$. The median value is $24,000 \mathrm{ft}^{2} / \mathrm{d}$. Details of published values are in the citations listed above; unpublished values were determined using drawdown/discharge data compiled from drillers' logs and the method of Bradbury and Rothschild (1985). Analysis of drawdown/discharge was limited to wells with screened intervals greater than $10 \mathrm{ft}$, and where discharge exceeded $10 \mathrm{gpm}$ for more than $1 \mathrm{hr}$. For most tests the simplifying assumptions required to compute transmissivity from drawdown/discharge are not completely valid; uncertainty associated with individual values is therefore significant.

The median transmissivity value, using both published and unpublished data for wells located in the central area of Tooele Valley, is about $30,000 \mathrm{ft}^{2} / \mathrm{d}$. The central area is defined as the area where land altitude is less than $4,700 \mathrm{ft}$. On average, central wells penetrate about $250 \mathrm{ft}$ of saturated fill. The average screened interval is about $130 \mathrm{ft}$ (roughly 50 percent of the saturated interval). For wells located along the valley margins (land altitude above 4,700 ft), the median transmissivity is about $10,000 \mathrm{ft}^{2} / \mathrm{d}$. These wells penetrate an average of about $200 \mathrm{ft}$ of saturated fill; the average screened interval is approximately $150 \mathrm{ft}$ (roughly 75 percent of the saturated interval).

Assuming that screens correspond to the coarse-grained water-bearing intervals, wells along the margin generally encounter more coarse-grained fill. Using lithologic information reported on drillers' logs, Lambert and Stolp (1999, p. 11) also concluded that coarse-grained fill is predominant along the margin of Tooele Valley. The inverse relation of more coarse-grained fill and lower transmissivity is likely a function of sorting. Transport to and deposition in the center of the valley probably resulted in better sorting of the fill. Sorting increases permeability and thereby transmissivity of the more limited coarse-grained fill in the center of the valley.

\section{Consolidated Rock}

Aquifer properties of the consolidated rock are extremely heterogeneous reflecting the complex structure and varied 
lithology. Generally, high hydraulic-conductivity values are associated with fractured quartzite; low values are associated with volcanic and carbonate rocks. Bulk permeability of consolidated rock in the Stansbury and Oquirrh Mountains is low. Using estimated recharge rates for the mountains, and interpolating a hydraulic gradient using high altitude perennial water sources (streams and springs) and mountain front water levels, bulk hydraulic conductivity is estimated to be 0.1 to $1.0 \mathrm{ft} / \mathrm{d}$. These values indicate that overall consolidated rock does not yield large amounts of water. Where fracturing exists groundwater movement can become focused, and the consolidated rock yields large amounts of water.

From pumping at individual wells, hydraulic conductivities for the various consolidated rocks in the mountain areas are estimated to range from 0.003 to $100 \mathrm{ft} / \mathrm{d}$. Lower values were determined for igneous rocks from calibration of a ground-water flow model of the northern Oquirrh Mountains (TriTechnics Corporation, 1996). The upper end of the range was determined for fractured quartzite on the basis of specificcapacity data from wells located along the mountain front between Middle and Settlement Canyons (pl. 1 and fig. 1). Hydraulic conductivity for consolidated rock west of Tooele City at TEAD is estimated to range from 6 to 481 $\mathrm{ft} / \mathrm{d}$ (Montgomery, 1988; Kleinfelder Inc., 2000). For the same area, hydraulic conductivity determined from estimated ground-water flow amounts and a measured hydraulic gradient is 20 to $150 \mathrm{ft} / \mathrm{d}$ (U.S. Army Corps of Engineers, 2007, p. 8 ). The storage properties of consolidated rock are approximations from calibration of the northern Oquirrh Mountain ground-water flow model (TriTechnics, 1996). Specific yield is estimated at $5 \times 10^{-3}$ and specific storage is estimated to range from $1 \times 10^{-6}$ to $1 \times 10^{-7} \mathrm{ft}^{-1}$.

Two interference tests were conducted to identify hydraulic connections between wells completed in the consolidated rock of the Oquirrh Mountains. One test was conducted near the mouth of Middle Canyon in November 2002 by pumping at wells (C-3-4)35add-3 and (C-3-4)35cbb-1 and observing water levels at well (C-3-4)35acd-1 (Appendix C, table 1). All three wells are completed in the consolidated rock. Well

(C-3-4)35add-3 is located at the mouth of Middle Canyon about $0.3 \mathrm{mi}$ east of the observation well and pumps at a rate of about 1,300 gpm. Well (C-3-4)35cbb-1 is located about 0.8 mi south of Middle Canyon and $0.6 \mathrm{mi}$ west of the observation well and pumps about 1,500 gpm. For the first $48 \mathrm{hr}$ of the test, only well (C-3-4)35add-3 was pumped; during the last $24 \mathrm{hr}$, well (C-3-4)35cbb-1 also was pumped. After $72 \mathrm{hr}$ of pumping, total water-level decline at the observation well was about 1.2 $\mathrm{ft}$. Water-level declines were observed at the observation well after about $24 \mathrm{hr}$ of pumping at well

(C-3-4)35add-3. The rate of water-level decline increased during the last $24 \mathrm{hr}$ of the test, when both wells were pumping. Increased declines demonstrate that both pumping wells are hydraulically connected to the observation well. This suggests that there is hydraulic interaction along the mountain front between well (C-3-4)35add-3 (mouth of Middle Canyon) and well (C-3-4)35cbb-1. There is no direct evidence, however, to establish the degree of interference between the two pumping wells.

The second test was conducted in September 2005 at the mouth of Settlement Canyon. Well (C-3-4)33acd-2

(Appendix C, table 1), completed in consolidated rock, was pumped at a rate of 3,000 gpm for $29 \mathrm{hr}$; the water level at the well declined about $110 \mathrm{ft}$. At well (C-3-4)33abd-1, completed in consolidated rock and located approximately $0.2 \mathrm{mi}$ north of the pumping well, water levels declined about $2.5 \mathrm{ft}$ during the test. Drawdown began about 1 to $2 \mathrm{hr}$ after the start of pumping and decreased linearly over time. Water levels at observation well (C-3-4)34bad-1, also completed in consolidated rock, were not affected by pumping. The well is located about 0.9 mi northeast of the pumping well. At well (C-34)33dac-1, completed in stream-channel deposits about $0.4 \mathrm{mi}$ southeast of the pumping well, there was no obvious influence on water levels from pumping. Data are not adequate to determine whether the lack of response at wells (C-3-4)34bad-1 or (C-3-4)33dac-1 is due to hydraulic boundaries or the 29-hr pumping duration. A longer test might have induced waterlevel declines at farther distances from the pumping well. Water-level data collected by Stolp (1994) show that there is a hydraulic connection between the stream-channel deposits and Settlement Canyon Reservoir. Drawdown at the pumping well indicates that no hydraulic boundaries were intercepted during the 29-hr test.

\section{Movement}

Ground water within the basin generally moves from the mountains toward the central and northern areas of Tooele Valley. A map of the potentiometric surface, developed from water-level measurements at wells, gives a detailed description of ground-water movement in the basin (fig. 6). Water-level data near South Mountain indicate that ground water moves from northern Rush Valley to Tooele Valley. Data, however, are not sufficient to interpolate a potentiometric surface for northern Rush Valley.

Details of the potentiometric surface indicate a number of features that are likely the result of heterogeneities in hydraulic conductivity and(or) caused by buried consolidated-rock geometry and faulting. In the areas between Settlement and Pine Canyons and near Bates Canyon (pl. 1), water-level data show the existence of steep hydraulic gradients between the consolidated rock of the Oquirrh Mountains and the adjacent unconsolidated basin fill. These gradients are likely due to ground-water movement through areas of lower hydraulic conductivity. Both consolidated rock and unconsolidated basin-fill deposits in these areas appear to have lower bulk hydraulic conductivities.

Farther out in Tooele Valley, two additional areas of steep hydraulic gradient exist. One is at TEAD and the other near Erda (pl. 1). These areas are separated by a region where the hydraulic gradient is moderate and the general direction of ground-water movement is toward the west. The steep gradient at TEAD is attributed to changes in hydraulic conductivity 


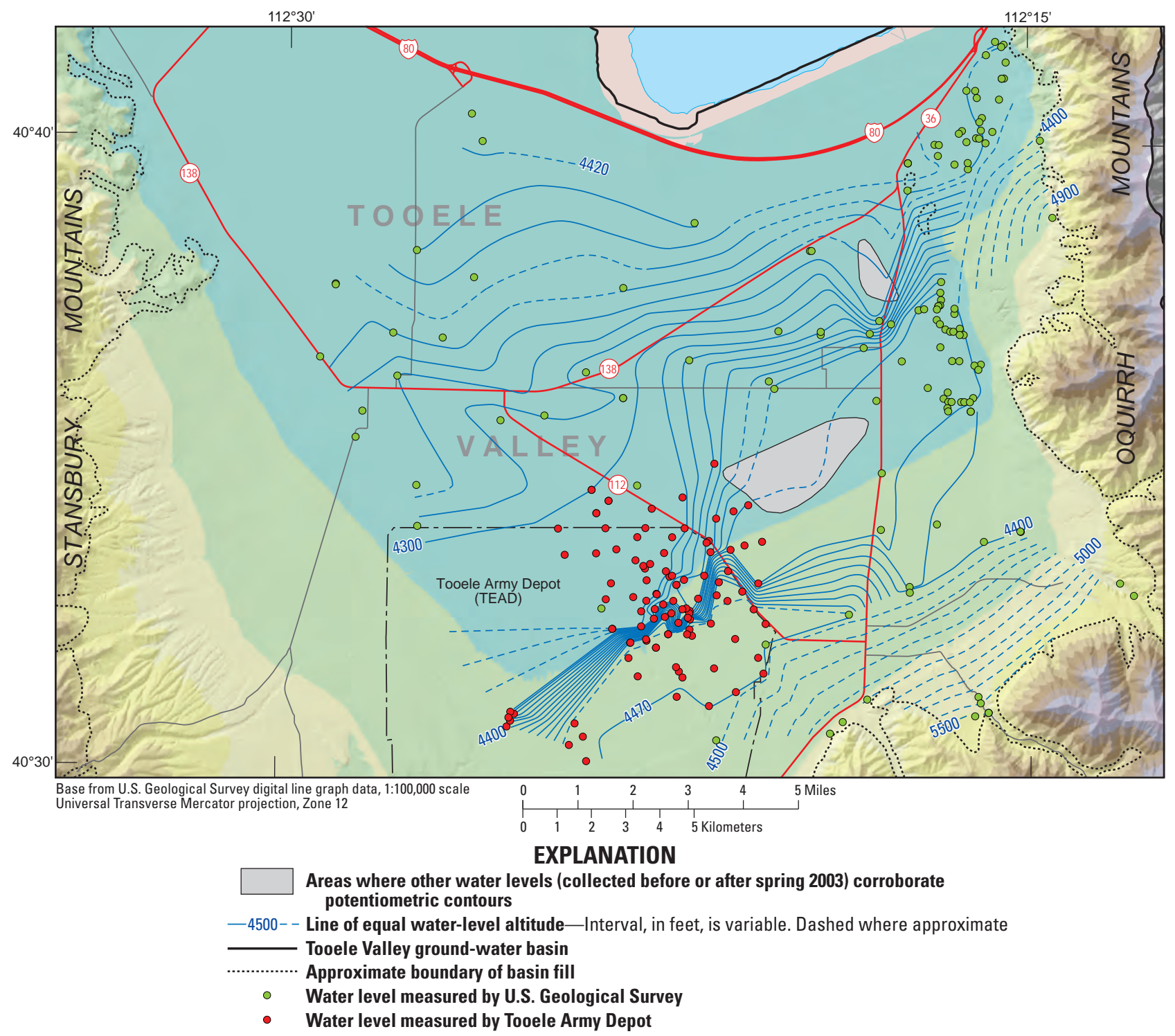

Figure 6. Approximate potentiometric surface, March 2003, Tooele Valley, Tooele County, Utah.

created by consolidated rock and associated fault zones buried in the subsurface (U.S. Army Corps of Engineers, 2004, fig. 2 ; U.S. Army Corps of Engineers, 2006, p. 14). At Erda, the steep hydraulic gradient is located near areas where consolidated rock crops out, but the cause of the steep gradient is not known.

Ground-water movement in the region between the steep hydraulic gradients likely is facilitated by a zone of relatively higher conductivity. Direct data are not available to confirm either the existence or cause of this postulated distribution of hydraulic conductivity. Underlying consolidated rock at TEAD (ERTEC, 1982; Asch, 2005) and east of Stansbury Park, likely has a complex topography. The topography would have directly influenced the depositional environment of the basin fill and thereby the hydraulic-conductivity distribution and movement of ground water within Tooele Valley. Both
Thomas (1946, p. 146) and Gates (1965, p. 17, fig. 5) discuss faults in the unconsolidated basin fill and their relation to movement and discharge of ground water. There is little surficial evidence of faulting on the valley floor; locations are inferred from a combination of geophysical, water-level, and water-quality data.

\section{Ground-Water Budget}

The ground-water budget is an estimate of average recharge to and average discharge from the ground-water basin. Amounts for individual components of the budget were estimated to represent average conditions within the basin starting in the later 1980s and extending through about 2005. The budget reflects the inherent interaction between individual processes and components of the ground-water system. 
An example is recharge from precipitation. Some portion of that recharge becomes baseflow discharge to streams in the mountains. A portion of that baseflow then becomes recharge from streams in the valleys. Another example is groundwater flow from northern Rush Valley to Tooele Valley. This component of the ground-water budget is recharge to Tooele Valley and discharge from northern Rush Valley. The transfer from a standpoint of the ground-water basin represents a zero net exchange, and is not part of the totals for the ground-water basin.

\section{Recharge}

The Tooele Valley ground-water basin is recharged primarily from precipitation in the mountains; a small amount of recharge is derived from valley precipitation. Other sources of recharge are irrigation water and streams (table 2).

\section{Precipitation}

Direct or in-place infiltration of precipitation into consolidated rock of the mountain areas is the most important source of ground-water recharge to the Tooele Valley ground-water basin. The amount and distribution of this recharge controls water levels and ground-water movement throughout the unconsolidated valley areas. The average annual recharge from precipitation in the mountains for the period 1971-2000 is estimated to be about 69,000 acre-ft.

Direct or in-place ground-water recharge from precipitation was determined using the Basin Characterization Model (BCM). The BCM is a distributed parameter, water-balance accounting model that computes whether and how much excess water is available in a drainage basin (Flint and Flint, 2007 , p. 6). Excess water is the component of precipitation not stored in soils, consumed by plants, or evaporated. Excess water can become either in-place ground-water recharge or surface runoff, depending on the saturated hydraulic conductivity of the consolidated rock and alluvium. The model

Table 2. Average annual ground-water budget, Tooele Valley ground-water basin, Tooele County, Utah.

[All flows in acre-feet per year. Budget components rounded to the nearest 100, totals rounded to the nearest 1,000. "Uncertainty" is a qualitative assessment that incorporates all factors used in the estimation of individual budget components]

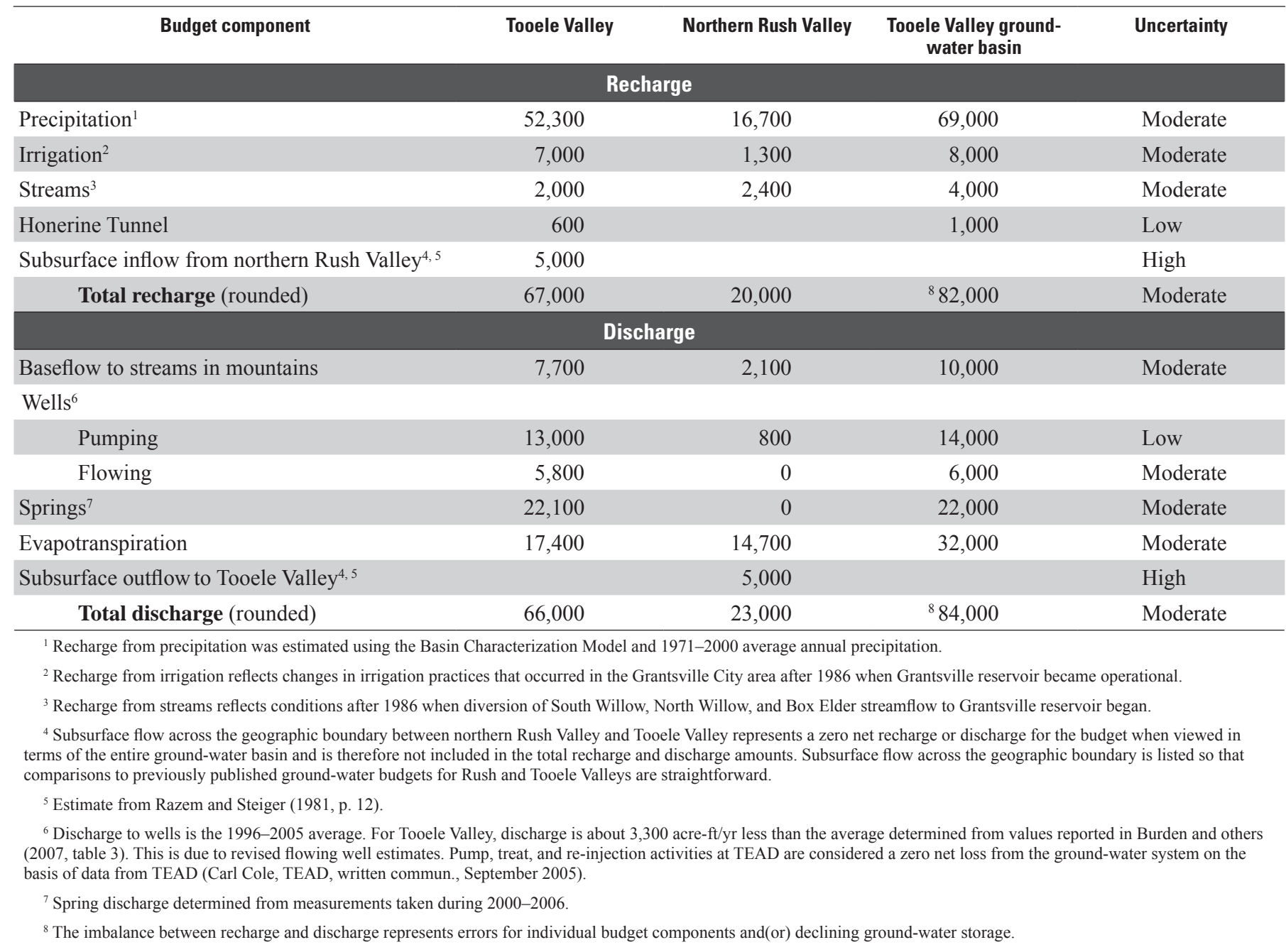


incorporates information on soil thickness and storage capacity, saturated hydraulic conductivity of soil and underlying material, potential evapotranspiration of vegetation, topography, precipitation, and air temperature to compute excess water. The BCM estimates of excess water (sum of groundwater recharge and runoff) approximated for each of the drainages in the ground-water basin (fig. 7) are listed in

table 3. The BCM for the Tooele Valley ground-water basin was constructed by Alan Flint of the USGS California Water Science Center (Alan Flint, USGS, written commun., September 2004) to compute 1971-2000 average excess water.

Excess water computed by the BCM for individual drainage basins was post-processed to determine both the amount and distribution of the in-place ground-water recharge. This was done by subtracting estimated streamflow runoff (table 1) from the excess water amount (table 3). Runoff was computed as the portion of streamflow in excess of baseflow during the high-flow months (generally May-August). Stream baseflow is not subtracted because it originates as ground-water recharge that eventually discharges back to the stream. Once runoff is subtracted, the 1971-2000 average annual precipitation isohyets (fig. 3) were used to distribute ground-water recharge within individual drainage basins. For example, the amount of ground-water recharge estimated for Settlement Canyon (fig. 7 , drainage basin boundary number 7) is 9,600 acre-ft/yr (table 3). Precipitation isohyets that overlay the Settlement Canyon drainage area range from 12 to $50 \mathrm{in}$./yr. The area below the 14-in. line was assigned a recharge rate of 1 to 3 percent of precipitation. For all other isohyet bands (precipitation ranges), the percentages of precipitation that become recharge were iteratively adjusted until total ground-water recharge matched the estimated 9,600 acre-ft/yr. This was done for

Table 3. Average annual (1971-2000) precipitation, streamflow, and in-place ground-water recharge from precipitation, Tooele Valley ground-water basin, Tooele County, Utah.

[All amounts in acre-feet per year]

\begin{tabular}{|c|c|c|c|c|c|}
\hline Drainage basin & $\begin{array}{l}\text { Drainage basin iden- } \\
\text { tifier, see figure } 7\end{array}$ & Precipitation & $\begin{array}{l}\text { Excess water (sum of } \\
\text { in-place ground-water } \\
\text { recharge and runoff) } \\
\text { computed by Basin } \\
\text { Characterization Model }\end{array}$ & Runoff, see table 1 & $\begin{array}{l}\text { Ground-water } \\
\text { recharge from } \\
\text { precipitation }\end{array}$ \\
\hline \multicolumn{6}{|c|}{ Tooele Valley } \\
\hline North Stansbury Mountains & 1 & 55,300 & 1,700 & 0 & 1,700 \\
\hline South Willow Creek & 4 & 50,700 & 7,000 & 2,700 & 4,300 \\
\hline Box Elder Creek & 5 & 36,400 & 6,900 & 400 & 6,500 \\
\hline Total Stansbury Mountains & & 204,600 & 24,200 & 5,900 & 18,300 \\
\hline Silcox Canyon & 6 & 26,000 & 2,100 & 0 & 2,100 \\
\hline Lake Point & 10 & 22,400 & 4,900 & 0 & 4,900 \\
\hline Sixmile Creek & 11 & 18,600 & 200 & 0 & 200 \\
\hline Total Oquirrh Mountains & & 177,300 & 41,400 & 7,400 & 34,000 \\
\hline Total Tooele Valley & & 381,900 & 65,600 & 13,300 & 52,300 \\
\hline \multicolumn{6}{|c|}{ Northern Rush Valley } \\
\hline Hickman Creek & 12 & 22,400 & 6,100 & 0 & 6,100 \\
\hline Clover Creek & 13 & 16,700 & 2,900 & 2,200 & 700 \\
\hline South of Clover Creek & 14 & 14,700 & 200 & 0 & 200 \\
\hline South Port Gulch & 15 & 8,400 & 400 & 0 & 400 \\
\hline
\end{tabular}




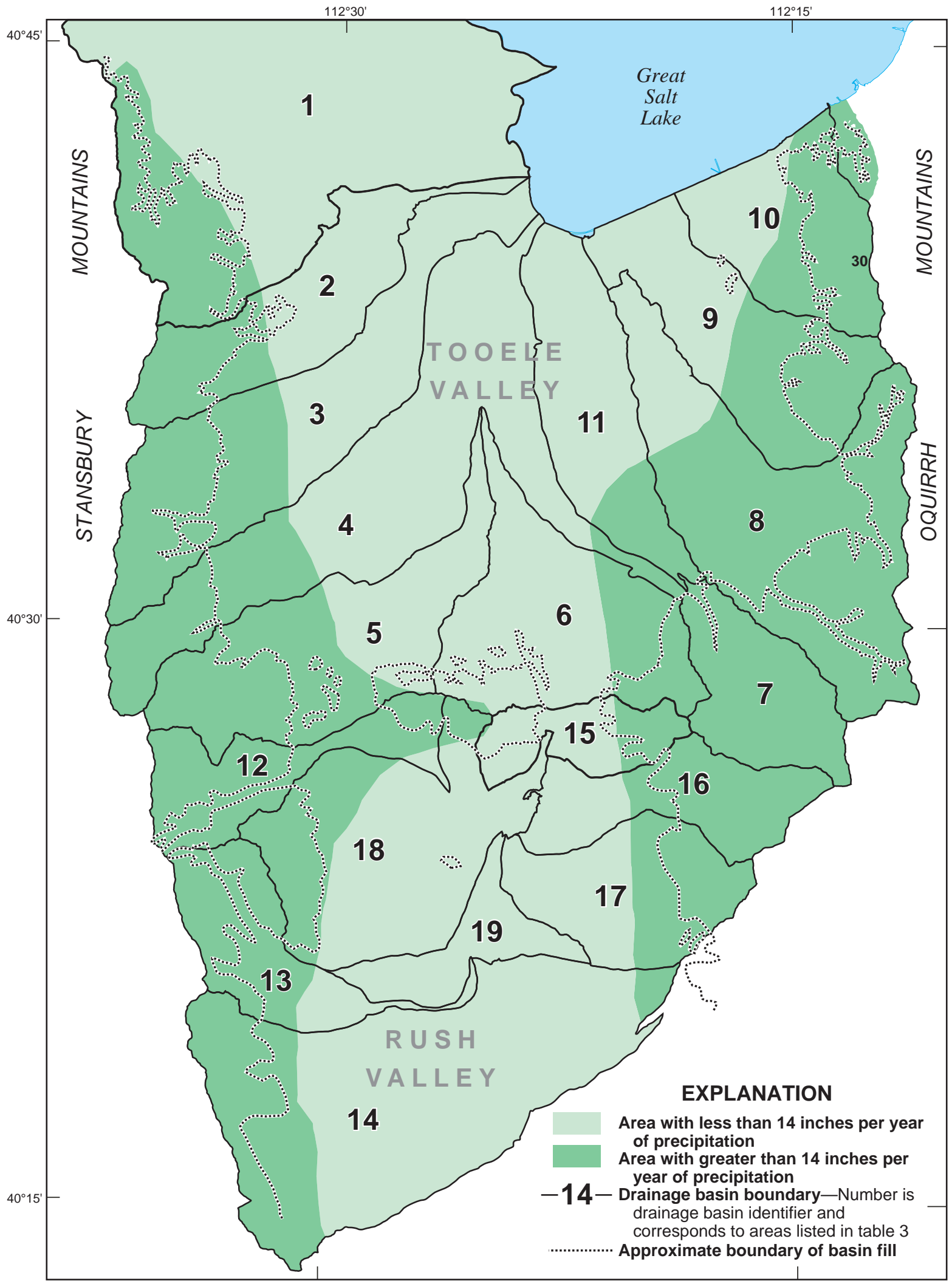

Base from U.S. Geological Survey digital line graph data, 1:24,000 scale

Universal Transverse Mercator projection, zone 12

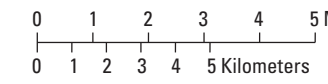

Figure 7. Hydrologic areas used to delineate recharge, Tooele Valley ground-water basin, Tooele County, Utah. 
the drainages that contain areas where precipitation is greater than 14 in./yr (areas 1-18). Percentages determined for each precipitation range are listed below; the percentage of precipitation that becomes in-place ground-water recharge increases as precipitation increases.

\begin{tabular}{cc}
\hline $\begin{array}{c}\text { Precipitation range } \\
\text { (inches) }\end{array}$ & $\begin{array}{c}\text { Percentage of precipitation that becomes } \\
\text { ground-water recharge }\end{array}$ \\
\hline $10-12$ & 1 \\
$12-14$ & $1-3$ \\
$14-16$ & $1-17$ \\
$16-20$ & $3-28$ \\
$20-28$ & $7-38$ \\
$28-34$ & $14-48$ \\
$34-38$ & $19-44$ \\
$38-44$ & $24-44$ \\
$44-50$ & $29-31$ \\
\hline
\end{tabular}

The distribution of ground-water recharge differs from previous estimates in that recharge is greater in the higher altitude mountain areas and less in the lower altitude valley areas. Recharge from precipitation in the valley areas (where average precipitation is less than $14 \mathrm{in} . / \mathrm{yr}$ ) is estimated to be about 2,100 acre-ft/yr. This equates to a recharge rate of about $0.01 \mathrm{ft} / \mathrm{yr}$ and accounts for about 2 percent of the ground-water budget (table 2). Previous estimates of recharge from precipitation in the valley areas was about 15 percent of the groundwater budget (Lambert and Stolp, 1999, table 6). These differences likely arise from soil-water storage processes (Flint and Flint, 2007, p. 9). Soils are thicker in the valley areas than in the mountain areas. Greater thickness in combination with relatively small amounts of precipitation results in low recharge estimates. Most infiltrating water is stored in the soils and eventually intercepted by plant roots and consumed by plant transpiration.

The estimate of recharge from precipitation is the 1971-2000 average. To get a sense of the annual variability of recharge, streamflow for South Willow Creek was compared to the annual variability in precipitation at Tooele City. Precipitation at Tooele City and streamflow in South Willow Creek were normalized to their respective averages. Analysis of the normalized records shows streamflow at South Willow Creek has a greater variability than precipitation (stream coefficient of variance is 0.42 , precipitation coefficient of variance is 0.23 ). For example, 1984 annual streamflow was 212 percent of the 1971-2000 average, whereas precipitation was 139 percent of average. This condition exists for many other years and indicates that consumptive use in a watershed (evapotranspiration by natural vegetation) might be adapted to long-term average precipitation. When precipitation exceeds the longterm average, consumptive use remains fairly constant and the amount of precipitation that becomes runoff or ground-water recharge becomes disproportionately larger. Annual waterlevel fluctuations also show disproportionate increases in response to above-average precipitation (see additional discussion in "Water-Level Fluctuations" section of this report).

\section{Recharge from Irrigation}

Recharge from irrigation water occurs in northern Rush Valley, Tooele City, Lake Point, Erda, and Grantsville City (fig. 1). The 1986-2000 average recharge from irrigation is estimated at about 8,000 acre-ft/yr. The estimate includes about 500 acre-ft/yr from irrigation of lawns and gardens (Lambert and Stolp, 1999, p. 15). Recharge from irrigation in the lowest areas of Tooele Valley is estimated as zero (Lambert and Stolp, 1999, p. 15, p. 30, p. 38, and fig. 13). An upward vertical hydraulic gradient limits recharge to shallow and localized circulation, which subsequently discharge as evapotranspiration and flow to drains and ditches. This part of the ground-water flow system is not included in recharge and discharge calculations.

At Lake Point and Erda, irrigation recharge was assumed to equal 25 percent of applied water (Stolp, 1994, p. 18). The source of irrigation water is ground-water withdrawals at wells; annual fluctuations were assumed minimal and the amount of recharge was considered equal to previous estimates (Lambert and Stolp, 1999, fig. 13). Recharge includes watering on lawns and gardens and is approximately 3,300 acre-ft/yr. The average amount of ground water withdrawn for irrigation in northern Rush Valley is about 800 acre-ft/yr, and the average surface-water availability is about 4,500 acre-ft/ yr. Using the same factor as in Tooele Valley ( 25 percent), the long-term average annual recharge from irrigation in northern Rush Valley is estimated at 1,300 acre-ft/yr.

Irrigation recharge near Tooele City and Grantsville City was examined in detail during this study. Near Tooele City, large ground-water-level fluctuations suggest that recharge varies considerably from year to year (see "Water-Level Fluctuations" section in this report). At Grantsville City, irrigation practices and application amounts have changed since 1986 following construction of the Grantsville reservoir.

To estimate recharge from unconsumed irrigation water near Tooele City, an average crop consumptive use was calculated. The average was subtracted from applied water to compute an annual recharge amount. This computation assumes that land use, crop type, and water application have been adaptively managed to match the average amount of available irrigation water. Irrigation water comes mainly from Middle and Settlement Canyon Creeks. Using average annual streamflow in Settlement and Middle Canyons and subtracting municipal Tooele City diversions and stream-channel losses (Stolp, 1994, table 5), an average amount of available irrigation water was approximated. The average crop consumptive use is estimated as available water minus average ground-water recharge, estimated by Stolp (1994, p. 18) at 25 percent of available water. Assuming an additional loss of 20 percent from surface runoff and other inefficiencies, the average amount of water available for consumptive use by crops is 55 percent of the applied water. The components and annual average recharge estimates are listed below.

When the annual amount of available irrigation water is greater than the average inefficiencies and consumptive use, 
the excess becomes ground-water recharge. Conversely, if the amount of available water is less than the average, recharge is limited to the residential recharge of about 300 acre-ft/yr. When streamflow from Middle Canyon and Settlement Canyon Creeks are varied in accordance with South Willow Creek streamflows, recharge from irrigation near Tooele City varies from 0.2 to 8.2 times the average ground-water recharge.

Completion of Grantsville reservoir in 1986 has had a significant impact on recharge from irrigation in the Grantsville City area. Before 1986, surface water used for irrigation in the area was diverted directly from streams in North Willow, South Willow, and Box Elder Canyons. The surface water, along with an average of 2,300 acre- $\mathrm{ft} / \mathrm{yr}$ of ground water, was used to irrigate approximately 1,200 acres of land. The main crop was alfalfa, which has a consumptive-use requirement of about $2.9 \mathrm{ft} / \mathrm{yr}$ (Utah Department of Natural Resources, Division of Water Rights, 2006).

Assuming that average precipitation in the area (12.96 in./yr, or $1.08 \mathrm{ft} / \mathrm{yr}$ ) is 80 percent effective (Utah Department of Natural Resources, Division of Water Rights, 2006), the crops require about $2.1 \mathrm{ft} / \mathrm{yr}$ of irrigation water. This equates to about 2,500 acre-ft/yr for the 1,200 acres of irrigated land. The available surface water is estimated to be 65 percent of the combined flow of the three streams (table 1), or about 6,200 acre-ft/yr. Assuming that 80 percent of surface water plus 80 percent of irrigation ground-water withdrawals are effective (Brooks and Stolp, 1995, table 6), then 7,000 acre-ft/yr reaches the root zone of the irrigated crop (alfalfa). Water that reaches the root zone and exceeds the consumptive-use requirement is considered to recharge the ground-water system. Before 1986, that amount averaged about 4,400 acre-ft/yr for areas near Grantsville City. With the completion of Grantsville reservoir in 1986, storage of surface water began and the method of irrigation changed from flood to pressurized sprinkler systems. More efficient use of surface water allowed crop production acreage to increase to 3,400 acres. This resulted in a corresponding increase in consumptive use to about 6,500 acre-ft/yr.
Reservoir storage and pipelines have made all surface water available for irrigation, and average ground-water withdrawals during 2003 were about 500 acre-ft/yr. Using these amounts of irrigation water, the average recharge from irrigation in the Grantsville City area has decreased to about 1,200 acre-ft/yr. This represents a 73 percent decrease (decrease of 3,300 acre$\mathrm{ft} / \mathrm{yr}$ ) in annual ground-water recharge since the completion of Grantsville reservoir in 1986. It is likely that the water-level declines observed in the area since the late 1990s are a result of this decrease in recharge (see "Water-Level Fluctuations" section in this report).

\section{Recharge from Streams}

Recharge from streams to the ground-water basin occurs along the mountain fronts where streams exit the mountains and flow into the adjacent valley. For 1971-2000, the average amount of recharge from streams is estimated to be about 4,000 acre-ft/yr. Available data describing stream loss is spatially and temporally limited and previously has been aggregated with recharge from consolidated rock (Lambert and Stolp, 1999, p. 14).

Recharge from Middle Canyon Creek was estimated for 1971-2000 to average about 1,100 acre-ft/yr. This estimate was made on the basis of reported losses of 32 percent from Middle Canyon Creek in the $1.1 \mathrm{mi}$ reach between (C-34)35aac and (C-3-4)26bbd (Stolp, 1994, table 5). It is assumed that the percentage of loss does not vary with streamflow. All discharge from Big Springs in Pine Canyon is considered ground-water recharge, even though a small part of the discharge is likely consumed by vegetation. Settlement Canyon Creek is almost entirely diverted to pipelines and probably only contributes recharge through the stream channel during times of high streamflow. Data quantifying recharge from Soldier Creek, Clover Creek, Box Elder Creek, South Willow Creek, and North Willow Creek are not available. Based roughly on the measured losses along Middle Canyon Creek, recharge along the unquantified creeks was subjectively

\begin{tabular}{|c|c|c|c|c|c|c|c|}
\hline \multirow[t]{2}{*}{ Stream } & \multicolumn{7}{|c|}{ Annual averages near Tooele City (acre-feet) } \\
\hline & $\begin{array}{c}\text { Streamflow } \\
\text { (see table 1) }\end{array}$ & $\begin{array}{l}\text { Tooele City } \\
\text { diversions }\end{array}$ & $\begin{array}{l}\text { Streambed seep- } \\
\text { age loss }\end{array}$ & $\begin{array}{c}\text { Available irrigation } \\
\text { water }\end{array}$ & Inefficiencies & Consumptive use & $\begin{array}{c}\text { Ground-water } \\
\text { recharge }\end{array}$ \\
\hline Middle Canyon Creek & 3,200 & 750 & 1,100 & 1,400 & 300 & 750 & 350 \\
\hline Settlement Canyon Creek & 7,200 & 750 & 0 & 6,400 & 1,300 & 3,500 & 1,600 \\
\hline Total & 10,400 & 1,500 & 1,100 & 7,800 & 1,600 & 4,200 & 2,000 \\
\hline
\end{tabular}

\begin{tabular}{|c|c|c|c|c|c|c|c|}
\hline \multirow[t]{2}{*}{ Stream } & \multicolumn{7}{|c|}{ Annual averages near Grantsville City before 1986 (acre-feet) } \\
\hline & $\begin{array}{l}\text { Streamflow } \\
\text { (see table 1) }\end{array}$ & $\begin{array}{c}\text { Available irrigation } \\
\text { water }\end{array}$ & $\begin{array}{l}\text { Ground-water } \\
\text { withdrawals }\end{array}$ & $\begin{array}{l}\text { Water from } \\
\text { precipitation }\end{array}$ & $\begin{array}{l}\text { Water reaching } \\
\text { the root zone }\end{array}$ & Consumptive use & $\begin{array}{l}\text { Ground-water } \\
\text { recharge }\end{array}$ \\
\hline North Willow Creek & 4,000 & 2,600 & - & - & - & - & - \\
\hline South Willow Creek & 5,100 & 3,300 & - & - & - & - & - \\
\hline Box Elder Canyon Creek & 600 & 400 & - & - & - & - & - \\
\hline Total & 9,700 & 6,300 & 2,300 & 1,300 & 7,900 & 3,500 & 4,400 \\
\hline \multicolumn{8}{|c|}{ Annual averages starting in 1986} \\
\hline Total & 9,700 & 9,700 & 500 & 3,700 & 11,100 & 9,900 & 1,200 \\
\hline
\end{tabular}


assigned 35 percent of the average annual streamflow (table 4). Starting in 1986, a pipeline diverted streamflow from North Willow, South Willow, and Box Elder Creeks for storage in Grantsville reservoir. No seepage is assumed from the pipeline system or reservoir, and recharge from these streams is considered negligible in 1986 and thereafter.

During spring snowmelt and directly after summer thundershowers, surface runoff and subsequent recharge can occur from ephemeral streams in drainages along the mountain fronts. In May 2005, ephemeral streamflow was observed and measured for Hickman Creek. At (C-5-6)20acc, about 2 mi upstream of the canyon mouth, flow on May 20, 2005, was $17.5 \mathrm{ft}^{3} / \mathrm{s}$. Six miles downstream at (C-5-5)32abb, measured streamflow on the same day was $6.9 \mathrm{ft}^{3} / \mathrm{s}$. This episodic

Table 4. Average annual recharge from streams, 1971-2000, Tooele Valley ground-water basin, Tooele County, Utah.

[All amounts in acre-feet, rounded]

\begin{tabular}{lcc}
\hline \multicolumn{1}{c}{ Stream } & $\begin{array}{c}\text { Average annual } \\
\text { streamflow }\end{array}$ & $\begin{array}{c}\text { Recharge from } \\
\text { streams }\end{array}$ \\
\hline Pine Canyon (Big Springs) & 900 & 900 \\
Middle Canyon Creek & 3,200 & 1,100 \\
Settlement Canyon Creek & 7,200 & 0 \\
North Willow Creek ${ }^{1}$ & 4,000 & 1,400 \\
South Willow Creek $^{1}$ & 5,100 & 1,800 \\
Box Elder Wash $^{1}$ & 600 & 200 \\
Hickman Canyon & 600 & 200 \\
Clover Creek & 3,600 & 1,300 \\
Soldier Canyon & 2,700 & 900 \\
Total & $\mathbf{2 7 , 9 0 0}$ & $\mathbf{7 , 8 0 0}$ \\
\hline
\end{tabular}

${ }^{1}$ Starting in 1986, loss from North Willow Creek, South Willow Creek, and Box Elder Creek is considered negligible because streamflow is piped to Grantsville reservoir. streamflow was estimated to have lasted about 6 weeks. Recharge from this event is estimated to be about 900 acre- $\mathrm{ft}$ and illustrates the potential variability in recharge, particularly during years of above average precipitation.

\section{Discharge}

Discharge from the Tooele Valley ground-water basin is by withdrawal from irrigation, industrial, public-supply, and domestic stock wells; discharge to springs and drains; and evapotranspiration. Little or negligible ground water is estimated to discharge directly to Great Salt Lake.

\section{Wells}

Discharge to wells from the Tooele Valley ground-water basin occurs by pumping and artesian flow (flowing wells). Estimated discharge to wells in 1939 in Tooele Valley was at about 7,000 acre-ft, almost all of it from flowing wells (Thomas, 1946, p. 230). The estimated total discharge to wells in 1962 was about 22,000 acre-ft (Gates, 1965, p. 25 and table 1). This threefold increase was due in part, to additional drilling and utilization of large diameter pumping wells for irrigation purposes. Starting in the late 1990s, pumping from municipal wells started to become a larger percentage of total discharge to wells. The estimated 1996-2005 average annual discharge from pumping wells is 14,000 acre-ft/yr. During that period, irrigation pumping ranged from 3,700 to 7,600 acre-ft/ $\mathrm{yr}$, and municipal and domestic/stock pumping ranged from 3,400 to 10,700 acre-ft/yr (fig. 8). Increased municipal pumping has changed the location of withdrawals, with more water being removed near the mountains from consolidated rock.

Pumping for industrial purposes was less than 1,000 acre$\mathrm{ft} / \mathrm{yr}$ during 1996-2005. As part of the remediation activities

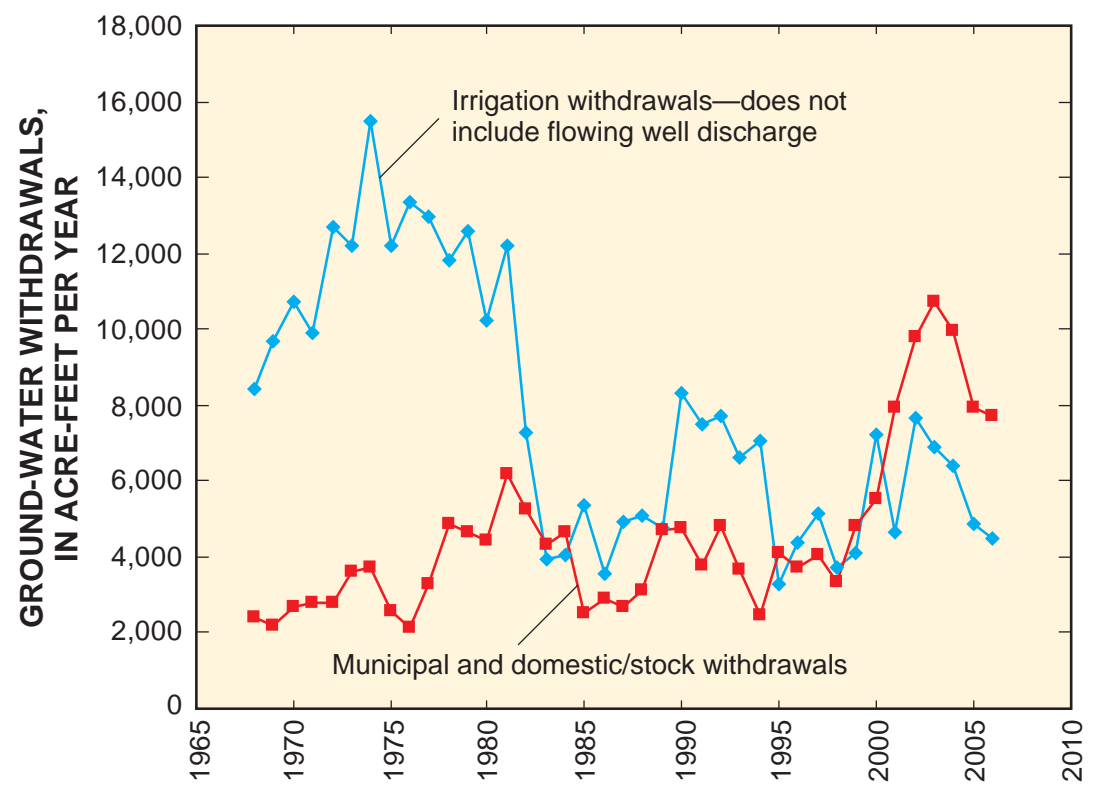

Figure 8. Annual ground-water withdrawals for irrigation and municipal uses, 1968-2006, Tooele Valley ground-water basin, Tooele County, Utah. 
at TEAD, a ground-water pump and treat system was operated from 1994 to 2004. During that time, an average of about $8,700 \mathrm{acre}-\mathrm{ft} / \mathrm{yr}$ was withdrawn from the ground-water basin. This water was treated and re-injected with essentially a zero net loss of water from the basin. Ground-water withdrawal data were compiled from the annual "G round-Water Conditions in U tah" reports published by the Utah Department of Natural Resources, Division of Water Resources; discharges related to remediation were provided by TEAD (Carl Cole, TEAD, written commun., September 2005).

Discharge to wells for irrigation for Tooele Valley in the annual "G round-Water Conditions in U tah" reports includes both pumping and flowing wells. Flowing well discharge is determined by scaling from a base discharge of 10,700 acre-ft/ yr determined by Gates (1965, table 1, p. 27). A subset of the wells used by Gates (1963, table 1) is measured annually (usually 10 to 15 wells) and the percentage difference from the previous year is computed for each measured well. A scaling factor is then computed by taking the average of the percentage differences. The previous year's flowing well discharge estimate is multiplied by the scaling factor to determine the current year flowing well discharge. During this study, most of the larger flowing wells originally visited by Gates (1963) were re-inventoried. As of 2005, 12 large flowing wells representing about 40 percent of the original base discharge $(10,700$ acre-ft/ yr) were either capped or equipped with pumps. In the wells equipped with pumps, discharge occurs only during pumping and is accounted for as part of the total pumping discharge. Considering these factors, estimated flowing well discharge in 2005 was 4,500 acre-ft. Using this as the new base discharge, average (1996-2005) flowing-well discharge was recalculated to about 5,800 acre-ft/yr. This updated flowing well discharge results in an average discharge to wells for Tooele Valley that is about 3,000 acre-ft/yr less than the 1996-2005 average reported in the 2007 Ground-Water Conditions Report (Burden and others 2007, table 3).

\section{Springs}

Discharge to springs is estimated at $22,100 \mathrm{acre}-\mathrm{ft} / \mathrm{yr}$ on the basis of measurements made for the period 2000-2006. The discharge estimate accounts for all the larger valley springs within the ground-water basin and includes known diversions (pl. 1 and table 5). Historical spring flow data exist, but were not used to determine discharge because of unknown factors associated with measurement locations and diversion structures. Other springs exist in the ground-water basin, mainly in the surrounding mountains and for the most part are incorporated in the computation of streamflow.

Although discharge from large valley springs probably does not vary greatly over time, spring flow listed in table 5 reflects conditions during the period of record. For Mill Pond and Rose Springs, the period of record is longer and flows are somewhat more representative of an average. Only discharge at Mill Pond Spring is monitored on a continuous basis and the gaging record was examined for seasonal and annual discharge variability.

Mill Pond Spring consists of numerous orifices (both aerial and submerged) that discharge slow moving water into a broad channel (named "Mill Pond"). Discharge within the channel is difficult to measure; therefore the gaging station (USGS 403835112171801 (C-2-4)15cac-S1 Mill Pond Spring near Erda, Utah) is located about $1 \mathrm{mi}$ downstream from the head of Mill Pond, where flow is channeled into the concrete-lined Ezra Taft Irrigation Canal. Visual inspection of the gaging record for 2000-2006 shows a large degree of discharge variability (fig. 9). Mill Pond Spring is a significant natural discharge location (about 7 percent of the total estimated discharge from the ground-water basin) and variability reflects basin-scale seasonal and annual imbalances between recharge and discharge. Shorter time-scale variability in the gaged record is probably not an accurate reflection of true discharge from the spring. It is likely that upstream diversion and backwater within the Ezra Taft Irrigation Canal is causing

Table 5. Average annual discharge for selected springs determined from measurements made during 2000-2006, Tooele Valley ground-water basin, Tooele County, Utah.

[acre-ft/yr, acre-feet per year; $\mathrm{ft}^{3} / \mathrm{s}$, cubic feet per second]

\begin{tabular}{|c|c|c|c|c|}
\hline \multirow[t]{2}{*}{ Spring } & \multicolumn{2}{|c|}{ Average spring flow } & \multirow[t]{2}{*}{ Period of record } & \multirow[t]{2}{*}{ Number of measurements } \\
\hline & acre-ft/yr & $\mathrm{ft}^{3} / \mathbf{s}$ & & \\
\hline Mill Pond Spring ${ }^{1}$ & 5,700 & 7.9 & $2000-2006$ & 2,288 \\
\hline Fishing Creek Spring & 2,300 & 3.2 & 2004-2005 & 5 \\
\hline Factory-Dunne Springs & 7,200 & 10.0 & $2003-2005$ & 18 \\
\hline $\begin{array}{l}\text { Springs at the north end of the } \\
\text { Stansbury Mountains }{ }^{2}\end{array}$ & 3,300 & 4.6 & 2005 & 1 \\
\hline
\end{tabular}

${ }^{1}$ Mill Pond Spring discharge has been adjusted from reported values at Mill Pond Spring near Erda, Utah (station number 403835112171801) to include about 300 acre-ft/yr of diversions above the gaging station.

${ }^{2}$ Observations since 2005 indicate that discharge from the springs is variable and can be less than the measured value of $4.6 \mathrm{ft}^{3} / \mathrm{s}$. 


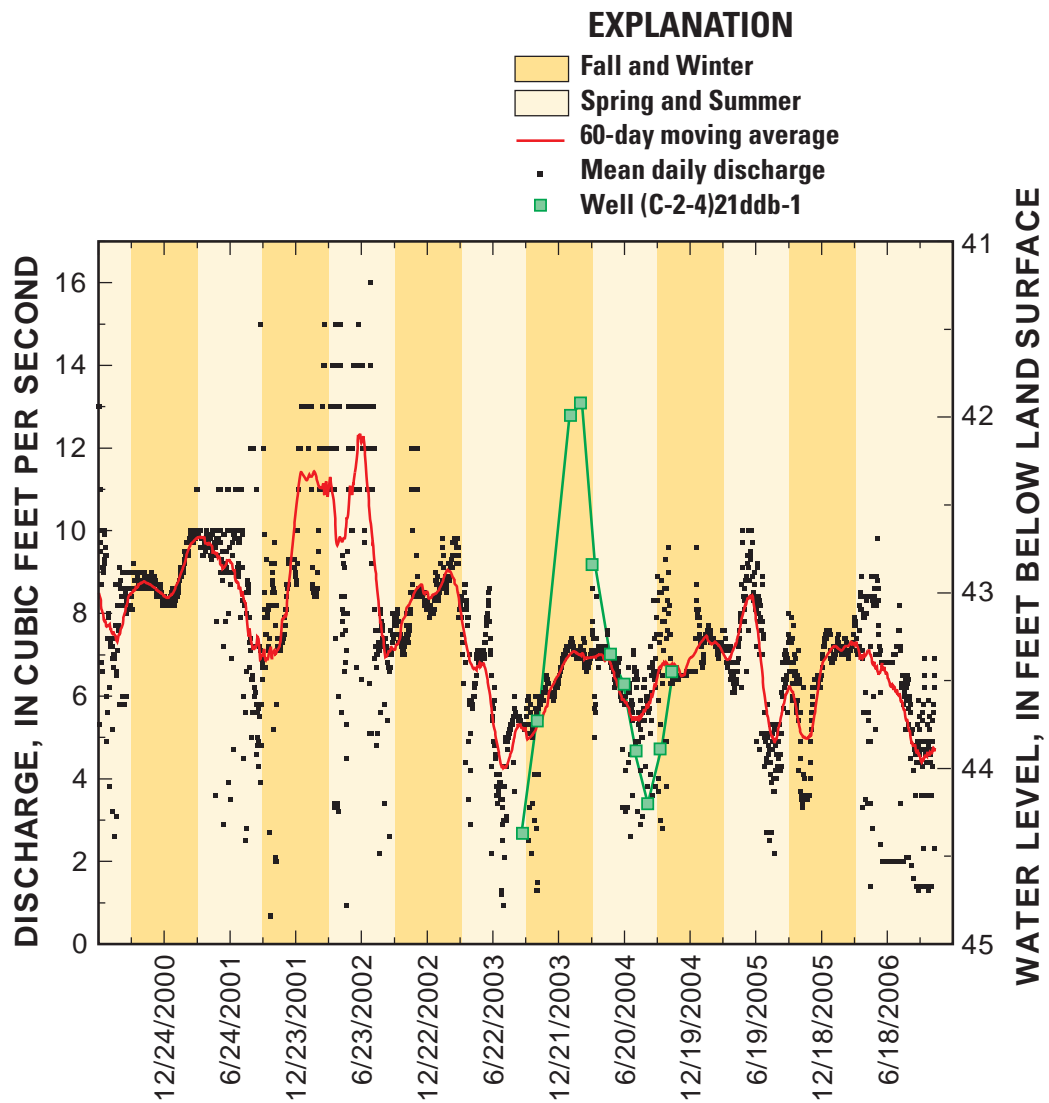

Figure 9. Discharge at Mill Pond Spring and water levels at well (C-2-4)21ddb-1, Tooele Valley ground-water basin, Tooele County, Utah.

the short-term variability. The upstream diversion is about 5 $\mathrm{ft}^{3} / \mathrm{s}$ once every week for $24 \mathrm{hr}$ and typically occurs during April through October. To activate the diversion, Mill Pond is dammed, which alters pool altitude. This in turn affects discharge from the submerged orifices (higher pool altitude artificially decreases spring discharge). Diversion creates the downward spikes in the discharge record. Backwater caused by debris and aquatic growth in the Ezra Taft Irrigation Canal likely creates the upward trends and spiking in the discharge record.

To remove the shorter time-scale variability attributed to diversions and backwater, the gaging record was smoothed using a moving average with a 60-day center window (fig. 9). Smoothing adds a component of uncertainty to the gaging record, but is helpful in recognition of general trends at the time scale of the moving window. Using the smoothed data, the gaging record indicates a general increase during fall and winter (September 21 to March 21) and decline in discharge during spring and summer (March 21 to September 21). The seasonal variability is similar to water-level fluctuations at well (C-2-4)21ddb-1 during 2003-04. The well is completed in unconsolidated basin fill and located about $1.3 \mathrm{mi}$ southwest of Mill Pond Spring. Water levels in the well rose about $2.5 \mathrm{ft}$ between September 2003 and February 2004 and declined by about the same amount between February 2004 and August 2004. For this same time period, the smoothed gaging record for Mill Pond Spring varied by about $2.5 \mathrm{ft}^{3} / \mathrm{s}$. Water-level declines at the well correspond to the time of year when ground-water withdrawal for both public supply and irrigation is at a maximum. Because of limited water-level data and noise in the gaging record, the causal relationship, which likely exists, is not clearly quantified.

\section{Evapotranspiration}

Evapotranspiration is the largest component of discharge from the ground-water basin (table 2). Ground-water discharge by evapotranspiration is defined as the consumption of ground water by plants with roots that extend into the shallow water table and by direct evaporation from mineral flats and playas underlain by shallow ground water. These conditions exist in northern Rush Valley and Tooele Valley (fig. 10). Annual ground-water discharge by evapotranspiration is estimated to average 14,700 acre-ft/yr in northern Rush Valley and 17,400 acre-ft/yr in Tooele Valley. Uncertainties associated with computation of evapotranspiration include extrapolation of measured evapotranspiration rates and scaling evapotranspiration rates across subareas.

Evapotranspiration was calculated by the following method: (1) identify areas where depth to the water table is generally within 15 to $20 \mathrm{ft}$ of land surface; (2) subdivide these areas into zones with similar physical characteristics, vegetation composition, and vegetation density [called evapotranspiration units (ET units)]; and (3) estimate an average vegetation consumptive-use rate for each of the ET units. For each of the ET units, the amount of surface-water run-on and precipitation also was estimated. The amount of ground-water discharge by evapotranspiration for each ET unit is calculated by determining total water use by the vegetation (total evapotranspiration) and subtracting precipitation and surface-water run-on. If the sum of precipitation and run-on is less than total evapotranspiration, then the difference is attributed to groundwater discharge by evapotranspiration. For areas where precipitation plus run-on exceeds total evapotranspiration, ground-water discharge by evapotranspiration is considered zero. Evapotranspiration computations are listed in table 6.

Evapotranspiration areas within Tooele Valley groundwater basin are shown on figure 10. In northern Rush Valley, the evapotranspiration area was initially delineated by Hood and others (1969, p. 27 and pl. 1) using a water-table depth of $50 \mathrm{ft}$. Measurement of evapotranspiration in areas of Nevada and California (Nichols, 2000; Berger and others, 2001) suggest that most ground-water evapotranspiration occurs when the water table is within 15-20 ft of land surface. Therefore, the western edge of the initially delineated Rush Valley evapotranspiration area, where depth to the water table is estimated to range from 20 to $50 \mathrm{ft}$, was removed. This results in about a 10 percent reduction in the evapotranspiration area 


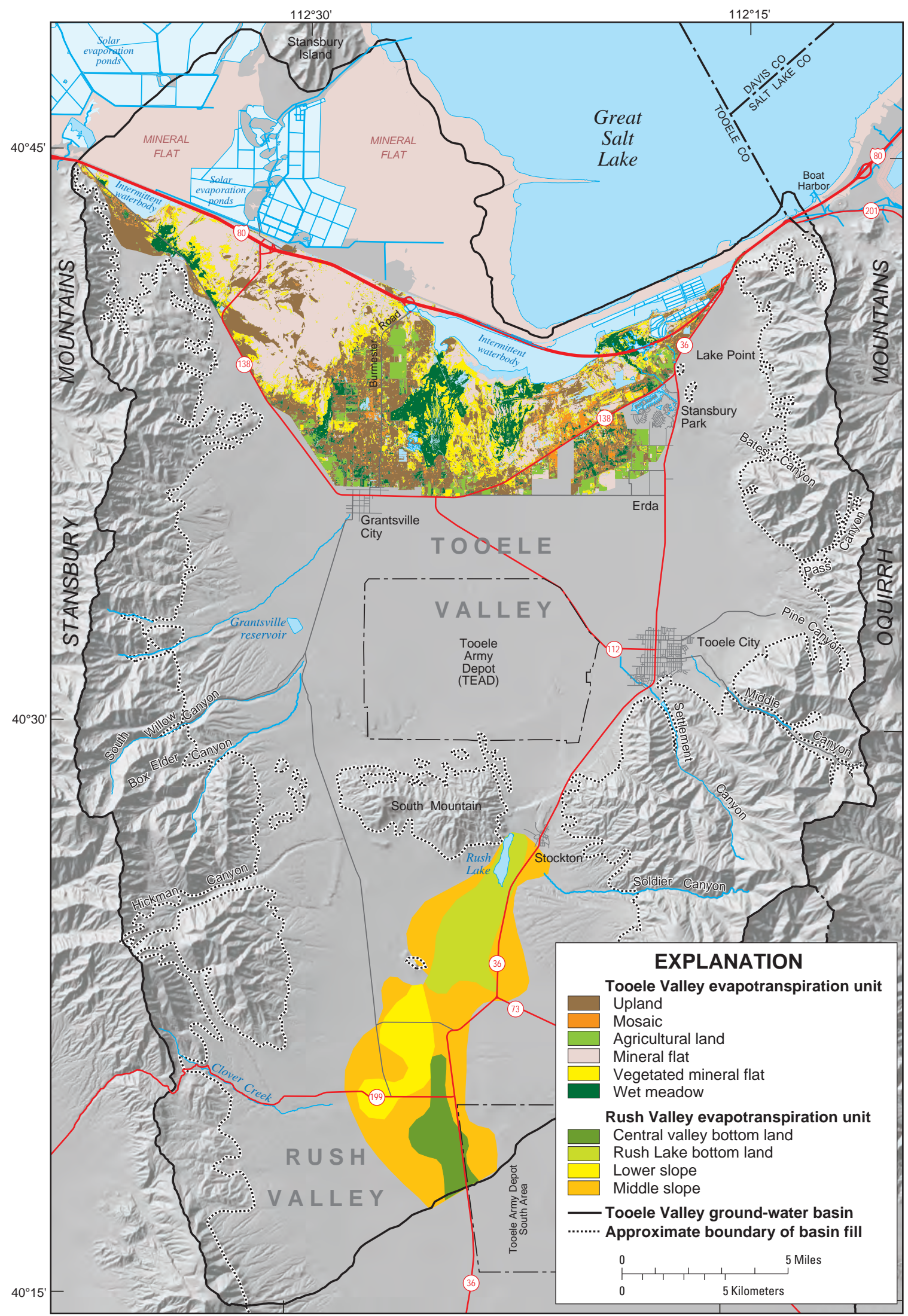

Base from U.S. Geological Survey digital line graph data, 1:24,000 scale

Figure 10. Location and classification of evapotranspiration units, Tooele Valley ground-water basin, Tooele County, Utah. 
Table 6. Evapotranspiration units and rates, Tooele Valley ground-water basin, Tooele County, Utah.

[Evapotranspiration rate: Modified from measured evapotranspiration rates in other areas and scaled to Tooele Valley ground-water basin using 1971-1990 average annual solar radiation. Water accumulation: Amount of surface water that flows onto the area and used by plants to meet water demand. Precipitation: 1971-2000 average annual precipitation. Average annual ground-water evapotranspiration: (Total area x Evapotranspiration rate) - (Total area x Precipitation) - Water accumulation. If (Total area x precipitation) + Water accumulation exceeds (Total area $x$ Evapotranspiration rate), the average annual ground-water evapotranspiration is considered to be zero]

\begin{tabular}{|c|c|c|c|c|c|c|c|}
\hline $\begin{array}{l}\text { Evapotranspiration } \\
\text { unit }\end{array}$ & $\begin{array}{c}\text { Physical } \\
\text { characteristics }\end{array}$ & Plant species & $\begin{array}{l}\text { Total area } \\
\text { (acres) }\end{array}$ & $\begin{array}{c}\text { Evapotranspiration } \\
\text { rate } \\
\text { (feet per year) }\end{array}$ & $\begin{array}{c}\text { Water } \\
\text { accumulation } \\
\text { (acre-feet per } \\
\text { year) }\end{array}$ & $\begin{array}{l}\text { Precipitation } \\
\text { (feet) }\end{array}$ & $\begin{array}{c}\text { Average annual } \\
\text { ground-water } \\
\text { evapotranspiration } \\
\text { (acre-feet) }\end{array}$ \\
\hline \multicolumn{8}{|c|}{ Northern Rush Valley } \\
\hline $\begin{array}{l}\text { Central valley bot- } \\
\text { tom land }\end{array}$ & Bare soil playas & & ${ }^{1} 2,400$ & ${ }^{3} 0.2$ & 0 & 1.1 & 0 \\
\hline $\begin{array}{l}\text { Rush Lake bottom } \\
\text { land }\end{array}$ & $\begin{array}{l}\text { Grassland, bare } \\
\text { soil, marshy land, } \\
\text { Rush Lake }\end{array}$ & & ${ }^{1} 4,200$ & ${ }^{4} 2.6$ & 0 & 1.1 & 6,300 \\
\hline Middle slope & Alluvial slope & $\begin{array}{l}\text { Greasewood, rab- } \\
\text { bitbrush, and sage }\end{array}$ & ${ }^{1} 11,000$ & ${ }^{5} 1.7$ & 0 & 1.1 & 6,600 \\
\hline Lower slope & Alluvial slope & $\begin{array}{l}\text { Greasewood and } \\
\text { rabbitbrush }\end{array}$ & 13,000 & ${ }^{5} 1.7$ & 0 & 1.1 & 1,800 \\
\hline \multicolumn{8}{|c|}{ Tooele Valley } \\
\hline Uplands & Non-wetland areas & $\begin{array}{l}\text { Geasewood and } \\
\text { rabbitbrush }\end{array}$ & ${ }^{2} 13,200$ & ${ }^{5} 1.7$ & 0 & 1.1 & 7,900 \\
\hline Mosaic & $\begin{array}{l}\text { Mixture of upland } \\
\text { and wetland veg- } \\
\text { etation }\end{array}$ & & ${ }^{2} 1,800$ & ${ }^{6} 1.3$ & 0 & 1.1 & 400 \\
\hline Agricultural lands & Cropland & $\begin{array}{l}\text { Row crops, hay, } \\
\text { and irrigated } \\
\text { pasture }\end{array}$ & ${ }^{2} 3,000$ & ${ }^{7} 2.8$ & 103,200 & 1.1 & 1,900 \\
\hline Mineral flats & $\begin{array}{l}\text { Bare flats with salt } \\
\text { crusts }\end{array}$ & $\begin{array}{l}\text { Little or no vegeta- } \\
\text { tion }\end{array}$ & ${ }^{2} 13,100$ & ${ }^{3} 0.2$ & 0 & 1.1 & 0 \\
\hline $\begin{array}{l}\text { Vegetated mineral } \\
\text { flats }\end{array}$ & $\begin{array}{l}\text { Interspersed bare } \\
\text { soil and vegetation }\end{array}$ & $\begin{array}{l}\text { Pickleweed, } \\
\text { iodinebush, and } \\
\text { inland saltgrass }\end{array}$ & ${ }^{2} 6,200$ & ${ }^{8} 0.5$ & 0 & 1.1 & 0 \\
\hline Wet meadow & $\begin{array}{l}\text { Low lying areas } \\
\text { dominated by } \\
\text { grassy vegetation }\end{array}$ & $\begin{array}{l}\text { Inland saltgrass, } \\
\text { Baltic rush, and } \\
\text { foxtail barley }\end{array}$ & ${ }^{2} 4,900$ & 93.4 & ${ }^{11} 4,100$ & 1.1 & 7,200 \\
\hline
\end{tabular}

\footnotetext{
${ }^{1}$ Area modified from Hood and Waddell, 1969, table 9.

${ }^{2}$ Area modified from SWCA Consultants, 2006.

${ }^{3}$ Evapotranspiration rate scaled from measured rate for bare-soil playa (DeMeo and others, 2003, table 3).

${ }^{4}$ Evapotranspiration rate scaled from average of measured rates for mixed grasses (DeMeo and others, 2003, table 3) and uplands (Marser and others, 2005, table 2: site number ET-1, p. 22).

${ }^{5}$ Evapotranspiration rate scaled from measured rate for desert-upland scrub (Berger and others, 2001, table 2).

${ }^{6}$ Evapotranspiration rate scaled from measured rate for phreatophyte-1 (Berger and others, 2001, table 2).

${ }^{7}$ Evapotranspiration rate scaled from average of measured rates for irrigated alfalfa and pasture (Maurer and others, 2005, table 2: site numbers ET-2, 3, and 4, p. 22).

${ }^{8}$ Evapotranspiration rate scaled from measured rate for pickleweed (DeMeo and others, 2003, table 3).

${ }^{9}$ Evapotranspiration rate scaled from measured rate for mixed grasses (DeMeo and others, 2003, table 3).

${ }^{10}$ Accumulated water consists of $1 / 2$ of average discharge from Fishing Creek Spring (1.8 cubic feet per second), $1 / 2$ of flowing well discharge in the Erda area ( 0.6 cubic feet per second), 1/2 of flowing well discharge near Fishing Creek (1.4 cubic feet per second), and 1/10 of average discharge from Mill Pond Springs (0.6 cubic feet per second).

${ }^{11}$ Accumulated water consists of $1 / 2$ of average discharge from Fishing Creek Spring (1.8 cubic feet per second), 1/10 of average discharge from Mill Pond Springs ( 0.6 cubic feet per second), and miscellaneous flowing well discharge ( 2.7 cubic feet per second).
} 
for northern Rush Valley. The ET units in Tooele Valley were delineated on the basis of a detailed wetland and adjacentupland classification conducted by SWCA Consultants (2006). The area north of Interstate 80 (I-80) is included in the SWCA Consultants' (2006) wetland classification, but was not considered part of any ET unit because the area is either beach or shoreline depending on the surface altitude of Great Salt Lake.

Determination of evapotranspiration rates for each of the ET units was made on the basis of measured evapotranspiration rates at Ruby Valley, Nevada (Berger and others, 2001), Death Valley, California (DeMeo and others, 2003), and Carson Valley, Nevada (Maurer and others, 2005). The evapotranspiration rates reported for these areas are point-specific measurements that depend on vegetation density, vegetation composition, and local climate. To estimate evapotranspiration rates for ET units in Rush and Tooele Valleys, a reasonable match was made between vegetation density and composition characteristics of the ET units and those of the locations where evapotranspiration measurements were made. Measured evapotranspiration rates consist of all water used by vegetation, which includes precipitation and surface-water run-on that occurred during the measurement period.

Corrections for variations in climatic conditions (other than precipitation) were made for Rush and Tooele Valleys by scaling on the basis of 1961-90 average solar radiation (National Solar Radiation Database, 2007). Evapotranspiration rates measured in Death Valley, California, were scaled using the ratio of solar radiation at Salt Lake City, Utah, to that at Tonopah, Nevada. The evapotranspiration rates measured in Carson Valley, Nevada, were scaled using the ratio of solar radiation measured at Salt Lake City to that measured at Reno, Nevada. For Ruby Valley, solar radiation at Elko, Nevada was used.

\section{Open-Water Areas in Northern Tooele Valley}

To better characterize hydrologic conditions at the terminal end of the ground-water basin, the open-water areas in northern Tooele Valley were investigated. Previous studies (Gates, 1965, p. 28; Razem and Steiger, 1981, p. 17) hypothesized ground-water movement in these areas to Great Salt Lake.

Northwest Tooele Valley (fig. 11, area 1) is the only place where surface-water outflow to Great Salt Lake was observed during the study period. Outflow is through culverts beneath I- 80 and was measured at $4.6 \mathrm{ft}^{3} / \mathrm{s}$ on June 24,2005 . Inflow to the area is from springs located along the north end of the Stansbury Mountains. Lacking information about surface area and storage of the open-water area, total spring inflow was considered equal to the measured outflow $\left(4.6 \mathrm{ft}^{3} / \mathrm{s}\right)$. This estimate is accounted for in the "Spring(s)" component of the ground-water budget (tables 2 and 5). During December 2007, springs in the area were discharging water, but the open-water area was smaller, and there was no surface-water outflow through the culverts.
Open water located at the intersection of Burmester Road and I-80 is small (fig. 11, area 2) and is approximately where the surface-water drainages of Warm Springs Slough, North and South Willow Creeks, Box Elder Creek, and Silcox Canyon coalesce (fig. 7). However, no water conveyance structures nor surface-water inflow were observed in spring 2005, and there was no surface-water outflow toward Great Salt Lake. The small amount of water that does exist appears to be ponded and probably represents localized runoff. The absence of surface-water inflow to the area suggests that streamflow from the drainages either becomes ground-water recharge or is consumed. That notion is incorporated into the computation of ground-water recharge as "Recharge from streams" and "Irrigation," and ground-water discharge as "Evapotranspiration" (table 2).

The open-water area east of the Burmester intersection (fig. 11, area 3) receives inflow from Sixmile Creek and Fishing Creek (during the winter). There were no observed outflows. In 2005, the estimated area of open water was $4 \mathrm{mi}^{2}$, likely in response to above-average precipitation (fig. 4). From late 2005 to spring 2007, the surface area decreased by about one-half (estimated) and the water was saturated with respect to chloride. Using an open-water evaporation flux of $32 \mathrm{in./}$ yr (modified from the evapotranspiration rate listed in table 6 to account for effects of hypersaline water [Oroud, 1995]), an average precipitation flux of $12 \mathrm{in./yr} \mathrm{(fig.} \mathrm{3),} \mathrm{and} \mathrm{the} \mathrm{esti-}$ mated inflow of $2 \mathrm{ft}^{3} / \mathrm{s}$ (probably a minimum), an equilibrium surface area is about $3 \mathrm{mi}^{2}$. This first-order estimate indicates there is little if any diffuse ground-water inflow needed to maintain the observed characteristics of this open-water area. Inferred from the absence of ground-water inflow is that the active flow system likely terminates near the southern extent of the open-water area. Subsurface inflow to adjacent areas of Great Salt Lake, which would require longer flow paths through progressively more fine-grained basin fill, is therefore also considered unlikely.

The open-water area near the intersection of I-80 and State Highway 36, originates from Mill Pond Spring, FactoryDunne Spring, Sixmile Spring, and miscellaneous flowing wells (fig. 11, area 4). There was no surface-water outflow to Great Salt Lake in 2005. Data for this open-water area are not available to determine a water balance or the possibility of diffuse ground-water inflow.

\section{Mining Activities in the Oquirrh Mountains}

Mining activities in the Oquirrh Mountains include one of the largest open-pit copper mines in the world, hundreds of miles of underground workings, and several dewatering tunnels and shafts. Most of these disturbances are on the east side of the Oquirrh Mountains and have almost certainly caused the local ground-water divide to shift west of the topographic divide. Likely, some amount of ground water that would naturally have been part of the Tooele Valley ground-water basin is now diverted to the east and out of the basin. 


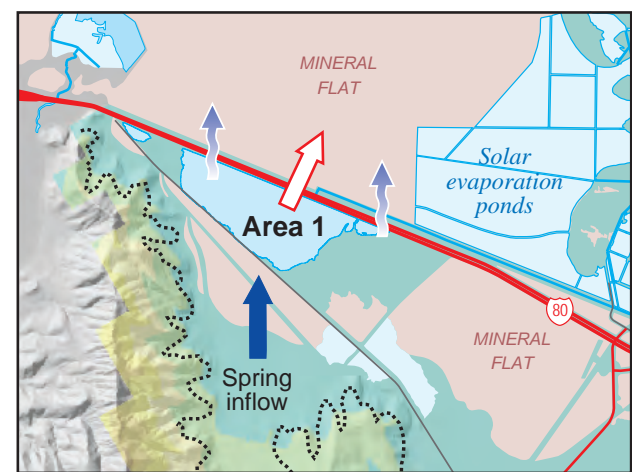

Inset 1 at 170 percent

EXPLANATION

Inflow

Outflow

Evaporation

Tooele Valley ground-water basin

Approximate boundary of basin fill
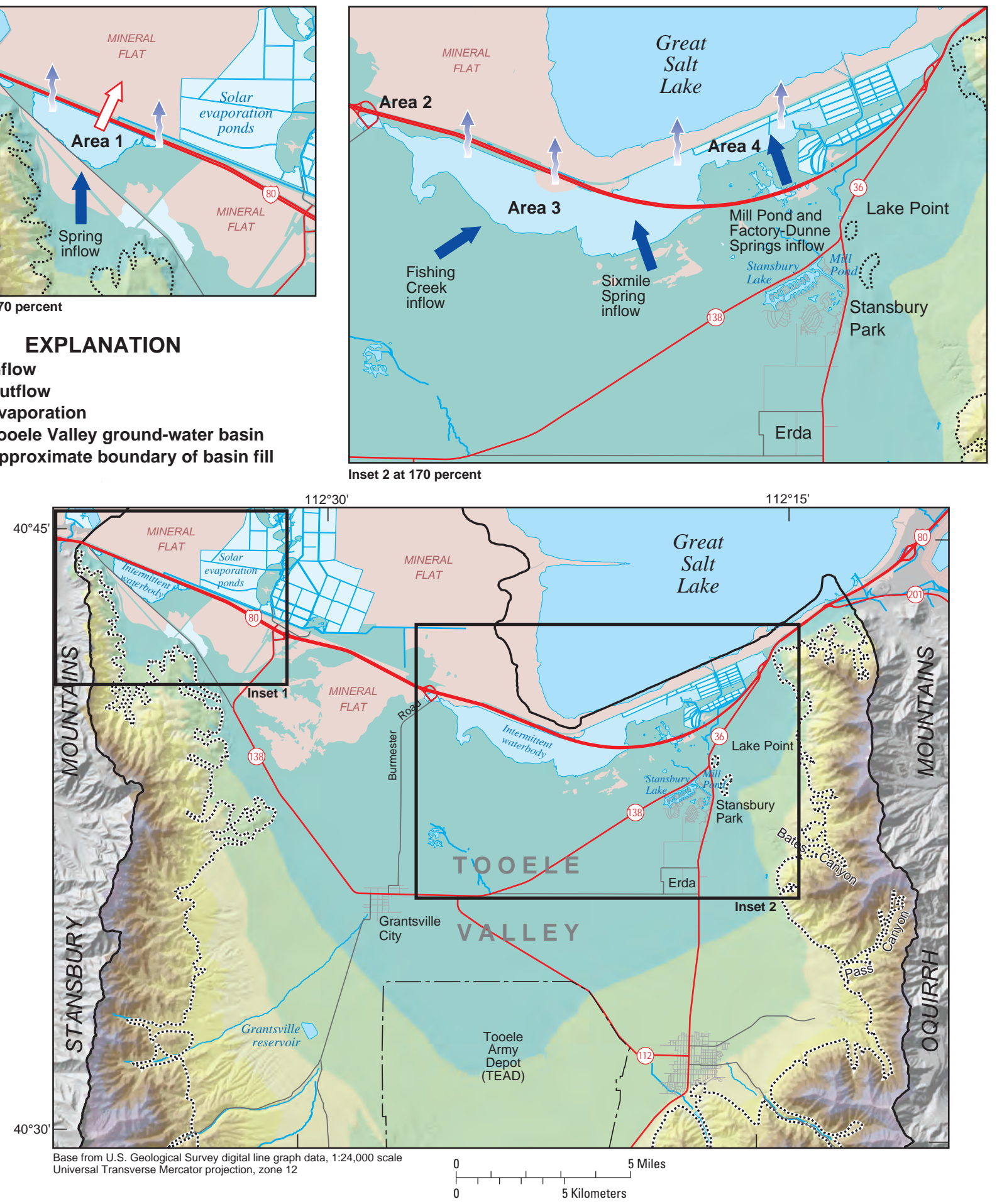

Figure 11. Water inflows and outflows for open water in northern Tooele Valley, Tooele Valley ground-water basin, Tooele County, Utah. 
In 2005, the total ground-water discharge associated with mining activities was estimated at 7,700 acre-ft (Enright and others, 2005; Brian Vinton, North American Exploration, oral commun., 2006). These withdrawals occur at a number of tunnels and shafts, but on the basis of proximity to the topographic divide, only the open-pit mine and the Carr Fork Service Shaft are considered potential points of diversion from the Tooele Valley ground-water basin. Total withdrawal from these two locations was 3,600 acre- $\mathrm{ft}$ in 2005. This amount is considered a maximum diversion out of the ground-water basin. Because of several mitigating factors, the probable range of diversion is estimated to be 700 to $1,400 \mathrm{acre}-\mathrm{ft} /$ yr. Withdrawals from the open pit $(1,100$ acre-ft) include precipitation, runoff, and ground-water inflow. Because the pit is located east of the divide, no precipitation or runoff is considered as diversion from Tooele Valley. The ground-water portion that is considered a diversion is estimated at 50 percent because only the western side of the pit is adjacent to the topographic divide. Carr Fork Service Shaft [(C-3-3)28bcd] is located on the Tooele Valley side of the topographic divide, and withdrawals are piped east in support of mine operations. Eighty percent of the underground workings intercepted by the shaft are located east of the topographic divide (Brian Vinton, North American Exploration, oral commun., 2006). Considering this, a rough estimate of total withdrawal diverted from the Tooele Valley side of the divide is $20-40$ percent. Additional analysis of Carr Fork Service Shaft withdrawals on the Tooele Valley ground-water basin is found in Appendix B.

\section{Water-Level Fluctuations}

Water levels fluctuate because of imbalances between ground-water recharge and discharge. Water levels rise when recharge is greater than discharge and decline when discharge exceeds recharge. Differences in recharge and discharge are caused by both natural and anthropogenic processes. Annual water-level fluctuations at four representative wells are shown in fig. 12A (locations shown on pl. 1) and demonstrate interannual changes in recharge and discharge. Water levels in wells near Tooele City, Grantsville City, and Erda (fig. 12A, hydrographs 1,2, and 3) all have a clearly defined period of higher water levels that resulted from increased recharge during 1983-84. Water levels also rose as a result of increased recharge from 1996-2000. These periods coincide with times when annual precipitation at Tooele City exceeded the 19712000 annual average for consecutive years. Five consecutive years of above-average precipitation occurred during the early 1980s and 2 years during the late 1990s (fig. 4). A single year of above-average precipitation does not appear to have affected water levels; perhaps the first year of above-average precipitation is utilized to replenish soil moisture. Water levels in wells located away from the primary recharge areas and near the end of the ground-water flow paths are characterized by much smaller fluctuations. Water levels at a well (fig. 12A, hydrograph 4) located north of Sixmile Creek and south of the third open-water area (fig. 11, area 3) indicate almost no annual change for the area.

Seasonal water-level fluctuations at four wells are shown in fig. 12B and highlight the seasonal nature of recharge and discharge. Water levels at wells in northern Rush Valley and at Tooele City did not fluctuate seasonally during 2002-2004 (fig. 12B, hydrographs 5 and 6). The lack of seasonal variation in northern Rush Valley indicates a degree of hydraulic isolation from both recharge in the nearby mountains and localized discharge to wells. The lack of seasonal variability at Tooele City is unexpected given the proximity to recharge sources (Oquirrh Mountains and irrigation) and the degree of interannual water-level fluctuation (fig. 12A, hydrograph 1). Precipitation during 2002-2004 was less than average (fig. 4). Consequently, recharge estimates from precipitation in the Oquirrh Mountains and irrigation for 2002-2004 are less than average. The thick unsaturated zone at Tooele City (greater than $500 \mathrm{ft}$ ) tends to attenuate seasonal water-level fluctuation from irrigation. Although precipitation was less than average, recharge is evident in the 2002-2004 water-level fluctuations at the well in Pine Canyon (fig. 12B, hydrograph 7). This well is completed in stream-channel deposits about 1.5 mi west of the Oquirrh Mountain topographic divide (the ground-water basin boundary). The seasonality of recharge from precipitation in the mountains is clear in the water-level fluctuations at the well. Interestingly, water levels at the well are unaffected by ground-water withdrawals from the consolidated rock at the Carr Fork Service Shaft, located about 1 $\mathrm{mi}$ to the east. This indicates that the stream-channel deposits in Pine Canyon may be reacting to small-scale localized recharge and at the location of the well, channel deposits are somewhat isolated from the surrounding consolidated rock. The lack of interference at the well may also indicate that ground-water withdrawals at the Carr Fork Service Shaft have minimal influence on hydrologic conditions in the Tooele Valley ground-water basin (see the section "Mining Activities in the Oquirrh Mountains"). At Grantsville City (fig. 12B, hydrograph 8 ), water-level declines during summer and fall, and recovery during winter and spring, are likely due to seasonal increases in ground-water withdrawals for irrigation and public supply.

\section{Water Quality}

During this study, water samples were collected from wells and surface-water sites. The first objective was to better delineate the general water quality in consolidated rock and unconsolidated basin fill described by Thomas (1946, p. 201), Gates (1965, p. 44), Razem and Steiger (1981, p. 28), Steiger and Lowe (1997), and Kenney and others (2006). The second objective was to help determine the relative amounts of ground-water recharge derived from precipitation and irrigation and to evaluate average ground-water velocities within the unconsolidated basin fill. 

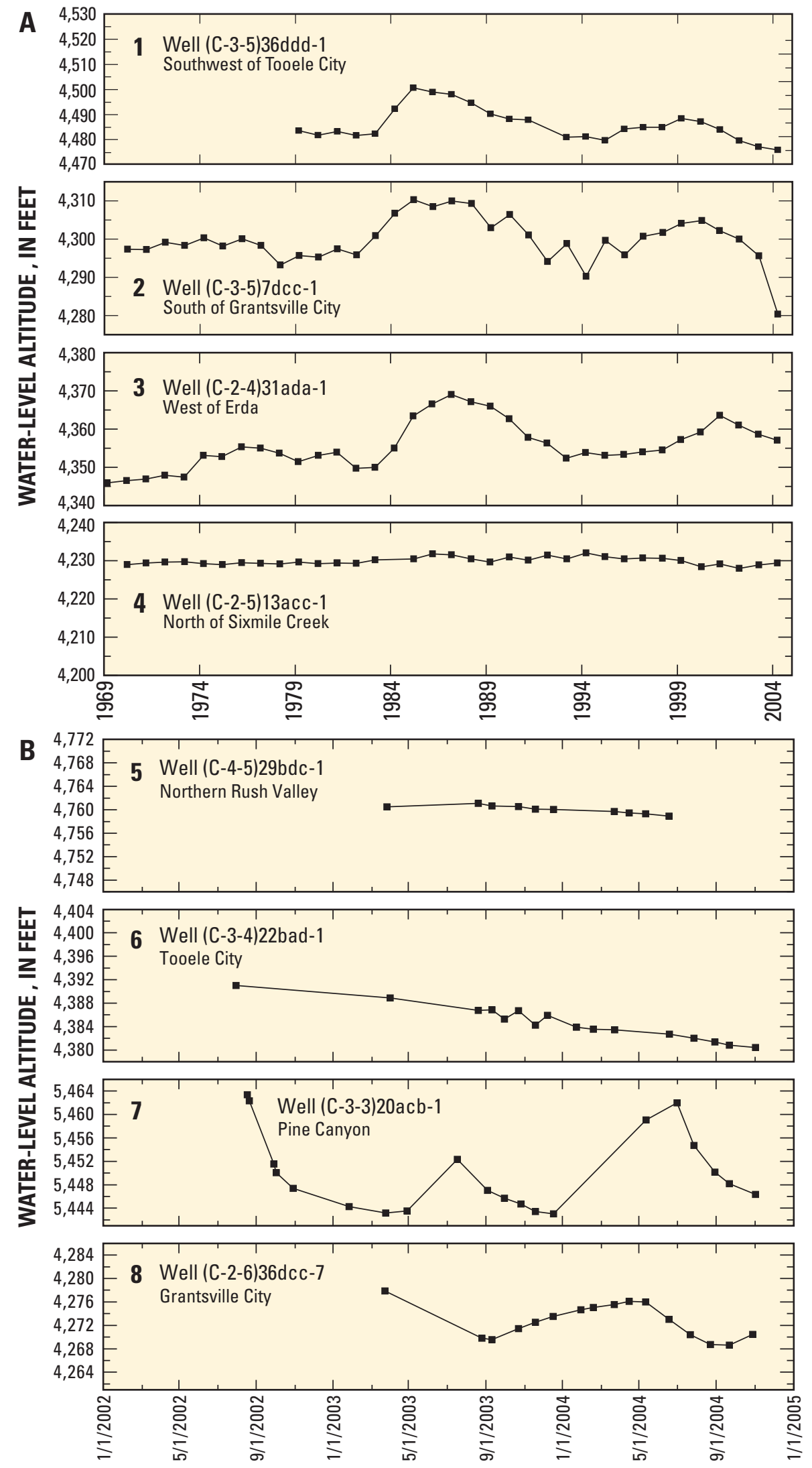

Figure 12. Annual (A) and seasonal (B) water-level fluctuations at selected locations, Tooele Valley ground-water basin, Tooele Valley, Utah. 


\section{Major lons, Nutrients, and Arsenic}

Analyses for major ions, nutrients, and arsenic (Appendix C, table 1 and pl. 1) were done to better describe source area and constituent-specific water-quality issues associated with historical mining activities and septic systems. Those water-quality concerns are discussed by Susong (1997; 2005), Wallace and Lowe (1998), Wallace (1999), Anderson Engineering, Inc. (2002), and Lowe and others (2004). No additional samples were collected to address the trichloroethylene in ground water at TEAD, which is monitored by the U.S. Army Corps of Engineers (2006).

The water with the lowest dissolved-solids concentrations exists in the mountain areas where most of the groundwater recharge occurs. The principal dissolved constituents are calcium and bicarbonate. Dissolved-solids concentration increases in the central and northern parts of Tooele Valley, at the distal ends of the ground-water flow paths. Increased concentration is due mainly to greater amounts of sodium and chloride. The trend reflects the fact that ground water has been in contact with aquifer materials for progressively longer periods as it moves from the mountains toward the valley discharge areas.

Results of analyses of samples collected for nutrient (nitrate plus nitrite) concentrations indicate the same general area of higher concentrations as delineated by Susong (2005, sheet 1). A water sample from one new monitoring well drilled near Lincoln, (C-3-4)13bbb-1, contained elevated arsenic. The well is located within the area of ground water with arsenic concentrations that exceed the U.S. Environmental Protection Agency standard of $10 \mu \mathrm{g} / \mathrm{L}$ (Susong, 2005, sheet 2).

\section{Environmental Tracers}

Environmental tracers used in this study include dissolved noble gases and isotopes of hydrogen (deuterium and tritium) and oxygen. Tabular results of environmental tracer concentrations are listed in Appendix C, tables 4 and 5, and a general discussion of methodology is presented in Appendix A.

\section{Deuterium and 0xygen-18}

The stable isotopes of water [deuterium $\left({ }^{2} \mathrm{H}\right)$ and oxygen-18 $\left({ }^{18} \mathrm{O}\right)$ ] were analyzed to better understand recharge sources to the ground-water basin. Most water molecules consist of hydrogen and oxygen- 16 . However, some water molecules (less than 1 percent) contain the heavier isotopes of ${ }^{2} \mathrm{H}$ and ${ }^{18} \mathrm{O}$. Heavier isotopes are more difficult to evaporate and easier to condense (liquid contains more heavy isotopes than the vapor evaporated from the liquid). The result is that the isotopic composition of ground water recharged from precipitation trends along the Global Meteoric Water Line (GMWL, fig. 13). The isotopic composition of ground water recharged from irrigation (which is reprocessed precipitation) trends along a line with a slightly shallower slope. Utilizing those characteristics, precipitation and evaporation trends were defined for the Tooele Valley ground-water basin

(fig. 13). The precipitation trend is offset to the right of the GMWL (with a ${ }^{2} \mathrm{H}$ excess factor of +8.1 permil verses +10 permil for the GMWL). Using the trends, ground-water recharge sources were categorized as either primarily precipitation, or a mixture of precipitation and irrigation.

Water that plots along the lower end of the precipitation trend (relatively more depleted) indicates higher-altitude and cooler-temperature precipitation. Water that plots along the upper end (relatively more enriched) indicates lower-altitude and warmer-temperature precipitation. Samples that plot along the evaporation trend indicate waters that are recharged, in part, by irrigation. The process of irrigation creates recharge in which the ${ }^{2} \mathrm{H}$ isotope has been concentrated by evaporation. Enrichment along the upper end of the evaporation trend denotes increased amounts of irrigation-derived recharge relative to precipitation-derived recharge.

Waters recharged from precipitation occur throughout the ground-water basin (fig. 14). This supports the general concept of the ground-water budget (table 2), which identifies precipitation as the main source of recharge to the basin. In general, depleted precipitation waters (indicating recharge from cooler, higher-altitude precipitation) are located in and near the mountains (fig. 14, map identifier 1).

Exceptions occur on both the east and west sides of Tooele Valley. Depleted samples collected from two wells located on the western side (fig. 14 and table 3, map identifier 2) are separated from the Stansbury Mountains by about $4 \mathrm{mi}$ of relatively low-altitude alluvial slopes. The depleted values suggests recharge from cooler, higher-altitude precipitation and very little recharge on the lower-altitude alluvial slopes. This agrees with estimates of minor natural recharge in valley areas where precipitation is in the range of $14 \mathrm{in}$./yr. The most enriched precipitation value was collected from a mountainfront well on the east side of the valley (fig. 14 and table 3, map identifier 5). The isotopic values suggest recharge from warmer temperature rainfall, which contradicts the concept of cooler temperatures associated with the higher-altitude terrain of Settlement Canyon. If the source of recharge was subsurface leakage and mixing with Settlement Canyon reservoir water (located about $1 \mathrm{mi}$ east of the well) the isotopic values would plot along the evaporation trend. It is more likely that water at the well is from recharge in Silcox Canyon, a loweraltitude mountain front drainage directly to the south.

Ground water near and along the mountain front between Settlement and Pass Canyons also has enriched precipitationderived values, indicating lower-elevation warmer-temperature recharge (fig. 14, map identifier 4). Farther out in the valley, the isotopic values indicate mixing with locally derived recharge from irrigation (fig. 14, map identifier 6). The precipitation values in ground water at northern valley locations (fig. 14, map identifier 3) probably correspond to ground-water flow paths converging to discharge via evapotranspiration and to springs near the terminal end of the active flow system. 
Precipitation recharge from the mountains reaches these areas along deeper and longer flow paths, and dilutes any localized irrigation recharge signal. Ground water with the highest percentage of irrigation recharge exists along the eastern margin of Tooele Valley between Pass and Bates Canyons

(fig. 14, map identifier 7). This is an area of current (2007) and historical irrigation. More importantly, the enriched evaporation values indicate negligible recharge from precipitation from the adjacent consolidated rock.

At the ground-water basin scale, the ${ }^{2} \mathrm{H} /{ }^{18} \mathrm{O}$ composition was examined to qualify uncertainties associated with the average annual 1971-2000 ground-water budget (table 2). Budget estimates for recharge from precipitation and streams is 71,000 acre- $\mathrm{ft} / \mathrm{yr}$ and recharge from irrigation is 10,000 acre-ft/yr. The average isotopic composition of precipitation (based on the samples used to define the precipitation trend) is -121.2 and -16.1 permil for ${ }^{2} \mathrm{H}$ and ${ }^{18} \mathrm{O}$, respectively. Using the samples that define the evaporation trend, an average estimate of irrigation recharge is -117.4 and -15.1 permil for ${ }^{2} \mathrm{H}$ and ${ }^{18} \mathrm{O}$, respectively. Weighting these components on the basis of the ground-water budget, an average isotopic value of fully-mixed water should be approximately -120.7 permil for ${ }^{2} \mathrm{H}$ and -16.0 permil for ${ }^{18} \mathrm{O}$. The average of the entire isotopic dataset is -119.6 and -15.7 permil for ${ }^{2} \mathrm{H}$ and ${ }^{18} \mathrm{O}$, respectively, suggesting that irrigation recharge might be somewhat more than the budget estimate.

\section{Tritium and Helium-3/Tritium}

Tritium $\left({ }^{3} \mathrm{H}\right)$ is a radioactive isotope of hydrogen that is incorporated into the water molecule and decays to helium-3 [tritiogenic helium-3 $\left.\left({ }^{3} \mathrm{He}_{\text {trit }}\right)\right] .{ }^{3} \mathrm{H}$ and the ratio ${ }^{3} \mathrm{He}_{\text {trit }}$ to ${ }^{3} \mathrm{H}$ are useful for framing a general time of recharge and thereby age of ground water. Ground-water age is the time as measured from when water enters the ground-water system (recharge) to its removal (discharge). Modern ground water is defined as having an apparent age of 50 years or less (recharged since the mid-1950s) and indicates relatively more recharge/discharge and active ground-water flow. Pre-modern ground water represents less active flow and hydrologic conditions that may be quite different from current (2007) conditions. Mixed waters reflect an integration of current and older conditions. The delineation between water that is younger and older than 50 years is possible because atmospheric ${ }^{3} \mathrm{H}$ concentrations increased two orders of magnitude above natural background concentrations during the period 1957 to 1963, due to above-ground nuclear weapons testing. Modern waters have higher concentrations of both ${ }^{3} \mathrm{He}_{\text {trit }}$ and ${ }^{3} \mathrm{H}$.

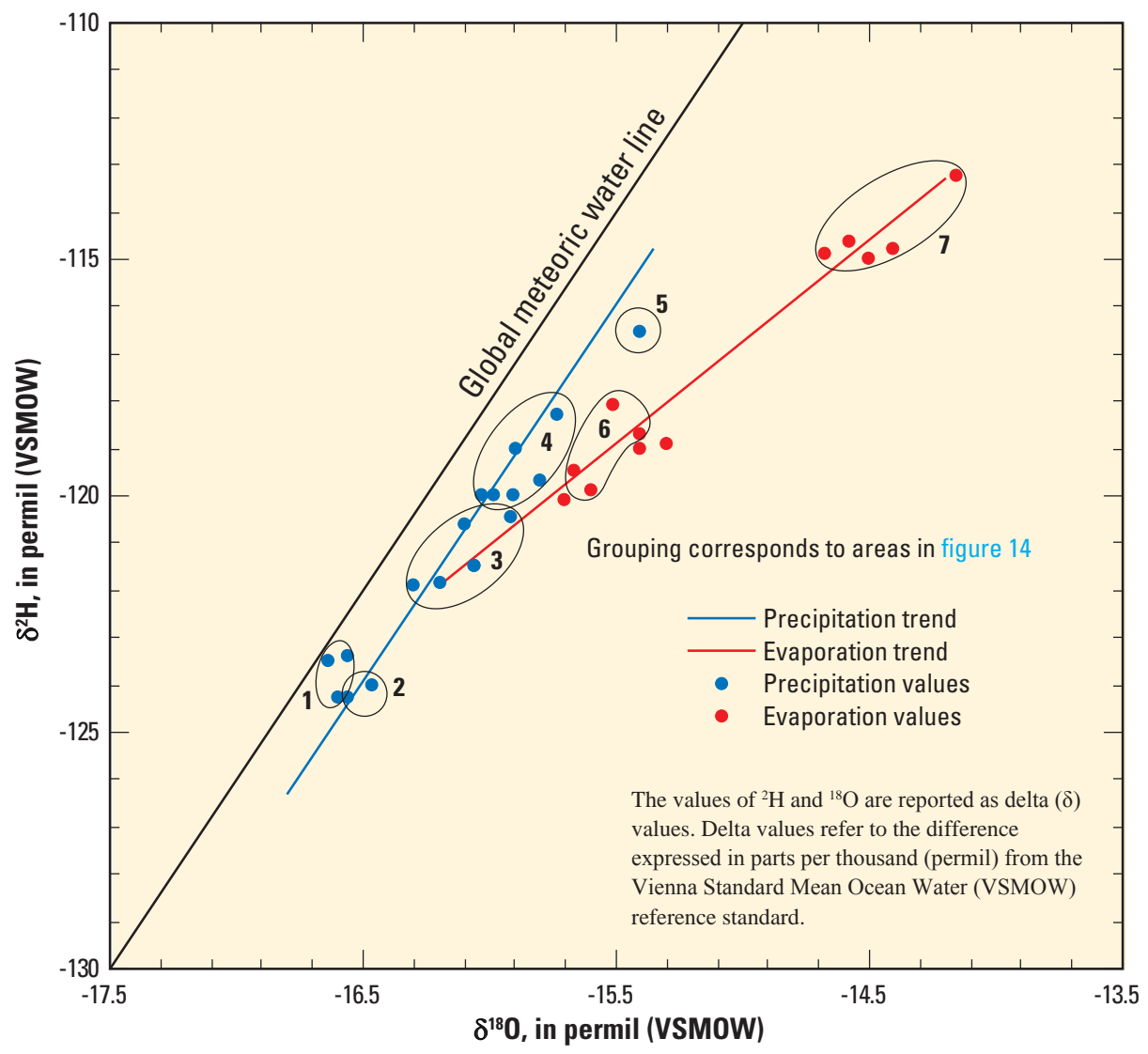

Figure 13. Relation between deuterium $\left(\delta^{2} \mathrm{H}\right)$ and oxygen-18 $\left(\delta^{18} 0\right)$ in ground water and springs, Tooele Valley ground-water basin, Tooele County, Utah. 


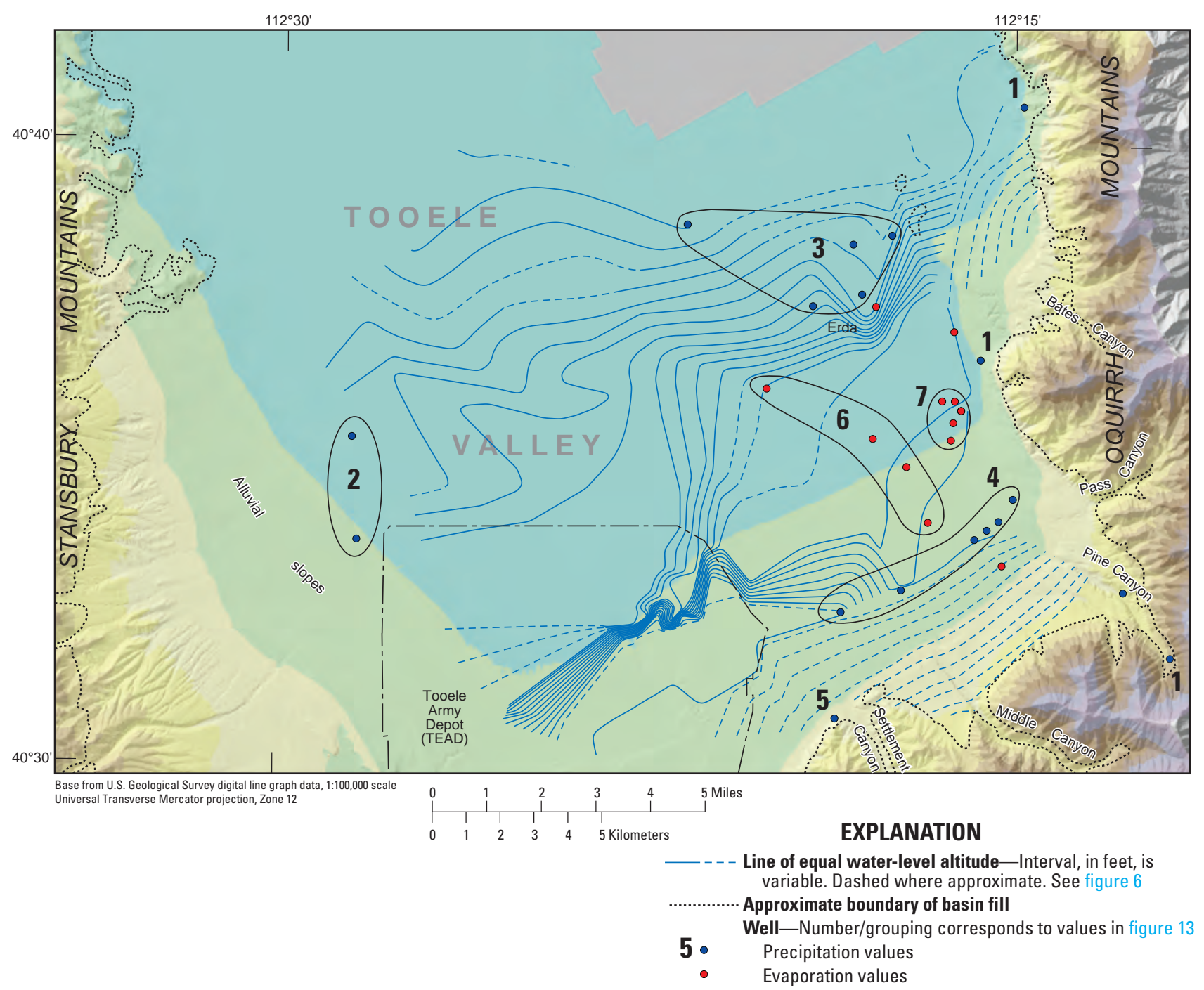

Figure 14. Selected deuterium $\left({ }^{2} \mathrm{H}\right)$ and oxygen-18 $\left({ }^{18} \mathrm{O}\right)$ sampling locations and potentiometric surface, Tooele Valley ground-water basin, Tooele County, Utah.

For the Tooele Valley ground-water basin, ${ }^{3} \mathrm{H}$ concentration of less than 0.5 tritium units (TU) was used to identify water that entered the flow system more than $50 \mathrm{yr}$ ago. Values less than $0.5 \mathrm{TU}$ assume decay from atmospheric concentrations prior to weapons testing, and dispersion compatible with estimates of average linear velocity and flow path distance between recharge and discharge areas of the basin. In combination with ${ }^{3} \mathrm{H}$, the noble-gas isotope helium-3 $\left({ }^{3} \mathrm{He}\right)$ can be used to refine the age estimation of ground water from preand post mid-1950s. A portion of measured ${ }^{3} \mathrm{He}$ is the result of ${ }^{3} \mathrm{H}$ decay (to ${ }^{3} \mathrm{He}_{\text {trit }}$ ); the ratio ${ }^{3} \mathrm{He}_{\text {trit }}$ to ${ }^{3} \mathrm{H}$ determines an apparent age (see Appendix A). Apparent refers to the fact that all water samples represent a combination of waters with different ages. ${ }^{3} \mathrm{He}_{\text {trit }}$ and ${ }^{3} \mathrm{H}$ also are used to qualify whether that combination of waters (or the mixture) bridges the mid-1950s age classification. The sum of ${ }^{3} \mathrm{H}$ and ${ }^{3} \mathrm{He}_{\text {trit }}$ is used to estimate an initial ${ }^{3} \mathrm{H}$ concentration $\left({ }^{3} \mathrm{H}_{\text {init }}\right)$ for the apparent recharge year. A sample is mostly modern if ${ }^{3} \mathrm{H}_{\text {init }}$ is similar to the estimated atmospheric concentration for the apparent recharge year. If ${ }^{3} \mathrm{H}_{\text {init }}$ is significantly less than the corresponding atmospheric concentration, then the sample probably contains pre-modern water.

The presence of ${ }^{3} \mathrm{H}$ and ${ }^{3} \mathrm{He}_{\text {trit }}$ indicates modern water exists along the flow paths originating in the Oquirrh Mountains between Settlement and Pass Canyons and extending between the steep hydraulic gradient areas at TEAD and Erda (fig. 15, map identifiers 11,12,13,14,15, and 16). This supports the concept of relatively more ground-water movement through this portion of the valley. ${ }^{3} \mathrm{H}$ systematically decreases along the flow path roughly delineated by sites $11,13,14,15$, and 10. Using distance between the sites, and the change in ${ }^{3} \mathrm{H}$, a first-order estimate of average linear ground-water velocity for the general area is roughly 2 to $5 \mathrm{ft} / \mathrm{d}$. This estimate is not precise given that ${ }^{3} \mathrm{H}$ concentrations in the atmosphere have varied over time. 


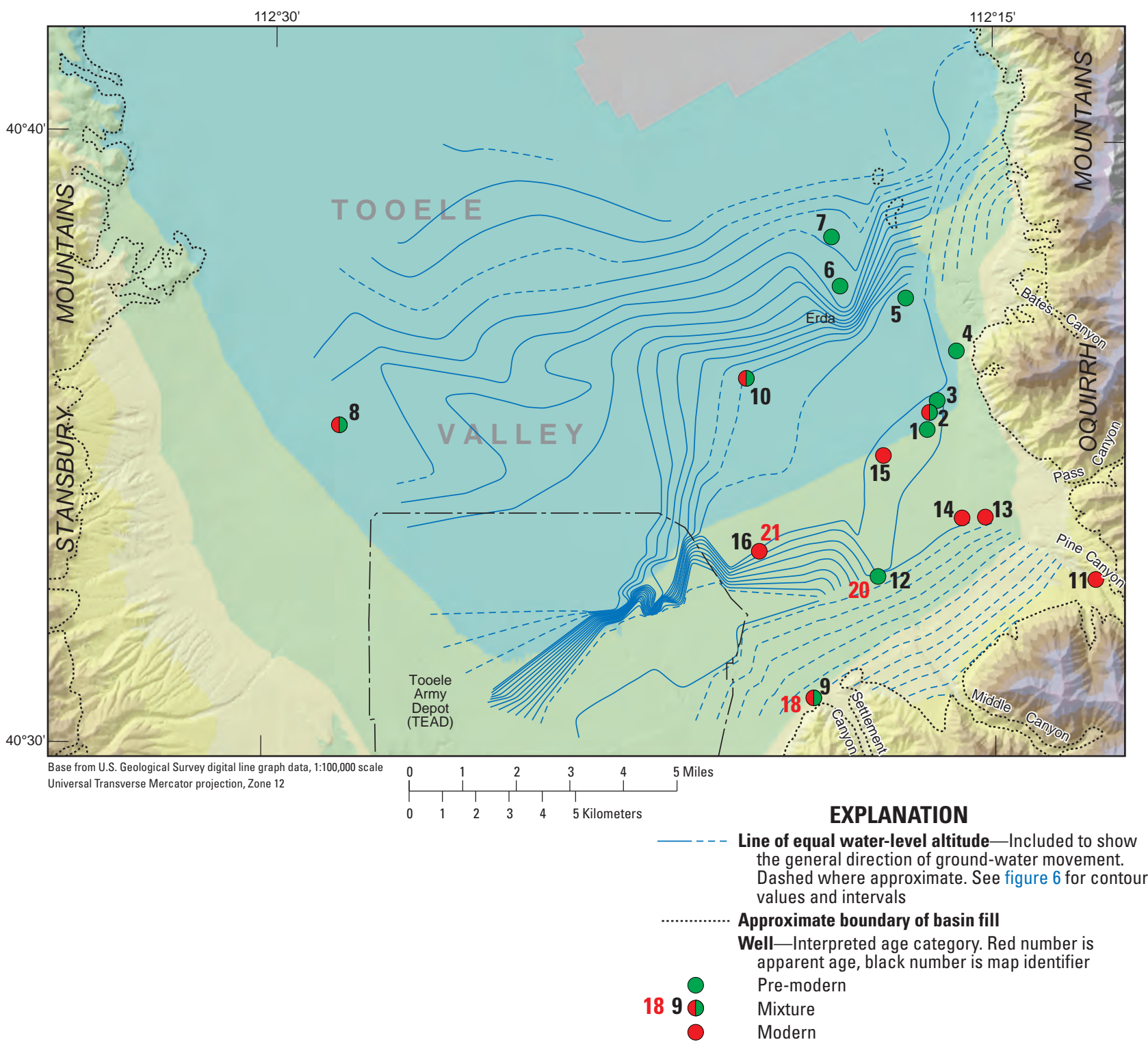

Figure 15. Helium-3/Tritium sampling locations, apparent age, and potentiometric surface, Tooele Valley ground-water basin, Tooele County, Utah.

The apparent age of ground water at sites 12 and $16(20$ and $21 \mathrm{yr}$, respectively) places some level of constraint on volumetric flow and aquifer properties for the area near Tooele City. The flow path lengths from the mouths of Middle Canyon to site 12 and Settlement Canyon to site 16 are about the same (approximately 13,000 ft). Using a measured hydraulic gradient ( 0.08 , see fig. 6$)$, a cross-sectional area of $1.1 \times 10^{7} \mathrm{ft}^{2}$ (product of saturated thickness, $1,000 \mathrm{ft}$, and distance between the canyons, $11,000 \mathrm{ft}$ ), and an estimate of porosity $(0.20)$, the following relationships were used to estimate flow and aquifer properties:

$$
Q=v n A
$$

and

$$
\mathrm{K}=\mathrm{vndl} / \mathrm{dh}
$$

where

Q is the volumetric flow rate,

$\mathrm{V}$ is the average linear ground-water flow velocity,

$\mathrm{n}$ is the average porosity,

A is the cross-sectional area normal to the ground-water flow direction,

$\mathrm{K}$ is the hydraulic conductivity, and $\mathrm{dl} / \mathrm{dh} \quad$ is the reciprocal of hydraulic gradient. 
Assuming a range of ages for ground water as it enters the basin fill from adjoining consolidated rock, the resulting values for aquifer properties and volumetric flow are listed below. Generally, age-based transmissivity values bracket the median value determined from well tests for the margin of Tooele Valley $\left(10,000 \mathrm{ft}^{2} / \mathrm{d}\right.$, see "Aquifer Properties" section of this report). Age-based volumetric flow exceeds the recharge estimate by $\mathrm{BCM}(24,100$ acre- $\mathrm{ft} / \mathrm{yr}$ for the drainage basins of Settlement, Middle, Pine, and Pass Canyons, see table 3) and recharge from irrigation (2,000 acre-ft/yr near Tooele City, see "Recharge from Irrigation" section of this report). Flows are less than a factor of two different when the age of water at the basin-fill/consolidated-rock boundary is set at $5 \mathrm{yr}$ or less. Volumetric flow due to irrigation recharge near Tooele City has an age of zero in this context.

Assuming the age of ground water at the basin-fill/ consolidated-rock boundary is less than $10 \mathrm{yr}$, aquifer property and flow estimates generally bracket those determined from well test analyses and recharge estimates. Variances are minor considering the assumptions and simplifications associated with each of the estimates. Consequently, the description of ground-water flow in the area between Settlement and Middle Canyons is reasonably well constrained.

Pre-modern age near Stansbury Park (fig. 15, map identifiers 6 and 7) is likely due to the convergence of longer and deeper ground-water flow paths. The potentiometric surface and ${ }^{2} \mathrm{H}$ and ${ }^{18} \mathrm{O}$ values (fig. 14) indicate that the source of ground water for the area is likely the Oquirrh Mountains between Settlement and Middle Canyons. Both flow path length (due to origin in southeastern areas of the basin) and deeper circulation would explain the existence of pre-modern age ground water near Stansbury Park.

Pre-modern water along the eastern margin of Tooele Valley between Pass and Bates Canyons (fig. 15, map identifiers 1-5) supports the ${ }^{2} \mathrm{H}$ and ${ }^{18} \mathrm{O}$ interpretation that there is little ground-water movement from the adjacent consolidated rock. On the other hand pre-modern water, even at relative shallow depths below the water table, contradicts the ${ }^{2} \mathrm{H}$ and ${ }^{18} \mathrm{O}$ interpretation of irrigation as a source of recharge. Irrigation occurred both before and after the 1950s in this area; irrigation recharge after the mid-1950s should have introduced ${ }^{3} \mathrm{H}$ into the ground water. One possible explanation could be that irrigation after the mid-1950s was mainly from local ground-water withdrawals. Considering that in 2003, local ground water contained small amounts (2 TU or less) of ${ }^{3} \mathrm{H}$, it is reasonable to assume the same for historical groundwater withdrawals. Assuming minimal exchange and mixing with atmospheric water, irrigation with low ${ }^{3} \mathrm{H}$ water would result in low ${ }^{3} \mathrm{H}$ recharge. These conclusions are speculative; available data are not sufficient to clearly explain the apparent inconsistency between the ${ }^{2} \mathrm{H}$ and ${ }^{18} \mathrm{O}$ data, and the low concentrations of ${ }^{3} \mathrm{H}$.

A mixture of modern and pre-modern water was interpreted for four locations (fig. 15, map identifiers 2, 8, 10 and 18). At Erda (site 10), the concentration of terrigenic helium-4 $\left({ }^{4} \mathrm{He}_{\text {terr }}\right)$ is greater than $5.0 \times 10^{-8} \mathrm{~cm}^{3} \mathrm{STP} / \mathrm{g}$ (see Appendix $\mathrm{A})$ and suggests a significant mixture with pre-modern water that is likely very old (on the order of 1,000 yr). Conversely, the ${ }^{3} \mathrm{H}$ concentration corresponds to the systematic decreases along the flow path originating at site 11 . The mixed water interpretation at site 18 is based on the presence of ${ }^{3} \mathrm{H}$, indicating modern water. Alternatively, the ${ }^{3} \mathrm{H}_{\text {init }}$ (determined from summing ${ }^{3} \mathrm{H}$ and ${ }^{3} \mathrm{He}_{\text {trit }}$ ) is about 30 percent of the atmospheric ${ }^{3} \mathrm{H}$ during the apparent recharge year, thus indicating a large pre-modern fraction. The mixed interpretation makes sense when compared to the ${ }^{2} \mathrm{H}$ and ${ }^{18} \mathrm{O}$ data. The ${ }^{2} \mathrm{H}$ and ${ }^{18} \mathrm{O}$ values correspond to possible recharge from precipitation in Silcox Canyon. Recharge from Silcox Canyon is much less than that estimated for Settlement Canyon (fig. 7, drainage areas 6 and 7; table 3). Less recharge implies a less active flow regime and the probability of pre-modern water.

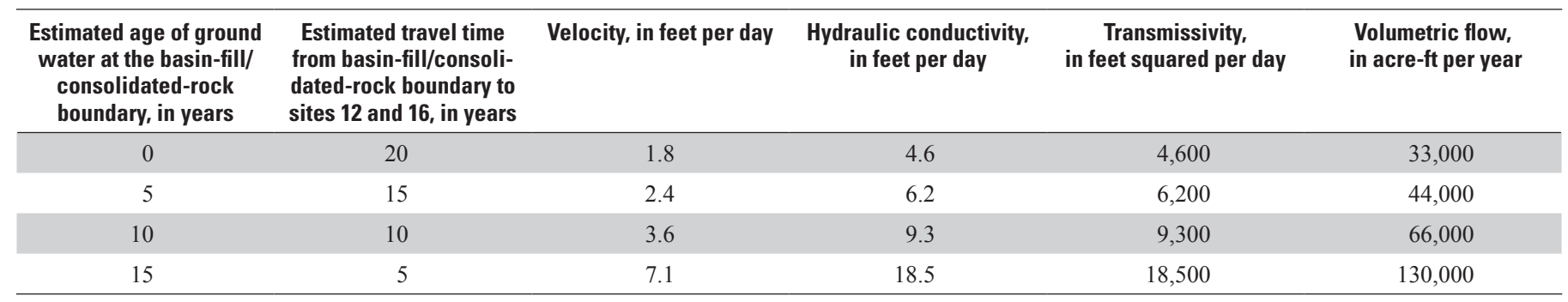




\section{Numerical Simulation of Ground-Water Flow}

A numerical ground-water flow model was developed to simulate ground-water flow in the Tooele Valley ground-water basin and to test the conceptual understanding of the groundwater system. A previous model (Lambert and Stolp, 1999) was modified to allow simulation of consolidated rock to the top of the Oquirrh and Stansbury Mountains and to incorporate new data obtained during the current study. Many new wells have been drilled in consolidated rock and in basin fill near the consolidated-rock boundary. Including consolidated rock allows the effect of withdrawal from these wells to be simulated and allows more realistic simulation of mountain recharge. Development of the model included compilation and examination of water-level, streamflow, and ground-water withdrawal data and estimation of the spatial distribution of recharge, discharge, hydraulic conductivity, and specific yield. The "Model Construction" section discusses the details of discretization, boundary conditions, and model parameters. The "Calibration" section discusses how the model was changed to match observed data and how adequately the model simulates the ground-water system.

The ground-water flow model was constructed using MODFLOW-2000, (Harbaugh and others, 2000; Hill and others, 2000). The terms "observed" and "observation" are used to define water-level and discharge data used as observations in the ground-water flow model (Hill and others, 2000, p. 23). The term "measured water level" refers to known levels that may or may not be included as observations.

\section{Model Construction}

Construction of the ground-water flow model required the discretization of the hydrologic properties of the ground-water system; establishment of model boundaries that represent conceptual hydrologic boundaries; determination of recharge rates and ground-water withdrawal rates for the steady-state simulation and for each stress period of the transient simulation; and assignment of model parameters to recharge, discharge, and aquifer characteristics. Given the amount and complexity of the input data, it is impractical to present or reference all required information to reconstruct the model from the information presented in this report. A copy of the model and associated data sets can be obtained from the USGS Utah Water Science Center, Salt Lake City, Utah.

The model described in this report uses parameters (Harbaugh and others, 2000, p. 4) to define much of the input data. A parameter is a single value that is given a name and determines the value of a variable in the finite-difference ground-water flow equation at one or more model cells. When parameters are used, the data value for a cell is calculated as the product of the parameter value, which might apply to many cells, and a cell multiplier, which applies only to that cell (Harbaugh and others, 2000, p. 13). Model parameters are listed in Appendix C, table 6. Sensitivity analysis (Hill and others, 2000, p. 98) was used to assess the relative importance of various parameters in the model and guide model construction and calibration.

\section{Spatial Discretization}

Areally, the model is discretized into a grid of rectangular cells; each cell has homogeneous properties. The boundary of active cells (fig. 16) delineates the lateral boundaries of the simulated ground-water system and generally corresponds with surface-water divides on the east and west boundaries, Great Salt Lake on the north boundary, and a ground-water divide in Rush Valley (Hood and others, 1969, pl. 1) on the south boundary. The rectangular model grid contains 120 rows and 130 columns. Cell size is small because of the complex flow paths and steep gradients in Tooele Valley (fig. 6) and to simulate more accurately interactions between surface water and ground water near springs and in the topographically steep areas of consolidated rock. Active cells range in size from about 55 to 110 acres. The model grid is rotated about 30 degrees counterclockwise from north to minimize the number of inactive cells. The ground-water flow equations are formulated at the center of each model cell. Flow area and gradient used to determine flow through the cell are determined at the center of the cell and represent the average area and gradient through the cell.

Vertically, the model is composed of five layers. Vertical discretization is used in the model to enable simulation of known vertical hydraulic gradients. The shallow unconfined aquifers in the northern part of Tooele Valley and the middle of Rush Valley are underlain by overlapping and discontinuous lenses of fine-grained material about $100 \mathrm{ft}$ below land surface in most areas (Lambert and Stolp, 1999, p. 5-7). These lenses provide a mostly continuous confining layer in the shallow parts of the valley fill and some hydraulic separation between water in deeper fill and water in shallow fill. Model layer 1 represents both the shallow unconfined aquifers and the underlying confining layers. Layer 1 is active only in the parts of the valleys where these aquifers are known to exist (fig. 16). The bottom of layer 1 is set $100 \mathrm{ft}$ below land surface. Layers 2, 3, 4 , and 5 represent both basin fill and consolidated rock and are active in the entire simulated area. Where layer 2 is overlain by layer 1 it is $150 \mathrm{ft}$ thick; elsewhere the saturated thickness of layer 2 varies from about 30 to about $540 \mathrm{ft}$. Layer 2 is confined where it is overlain by layer 1 and unconfined in other areas. Model layer 3 is $150 \mathrm{ft}$ thick and model layer 4 is 300 $\mathrm{ft}$ thick throughout the model area. The bottom of the model was set at an altitude of 3,100 ft. This allows a total simulated thickness of 1,100 ft near Great Salt Lake and is considered a sufficient depth to simulate the active flow system. The thickness of model layer 5 is calculated as the difference between the altitude of the bottom of model layer 4 and 3,100 ft; the thickness varies from $400 \mathrm{ft}$ near Great Salt Lake to about $4,100 \mathrm{ft}$ at the top of the Stansbury Mountains.

Model layers 1 and 2 were assigned as convertible layers in MODFLOW-2000. This allows layers to be confined if the simulated water level is above the top of the layer and unconfined if the simulated water level is below the top of the layer. 


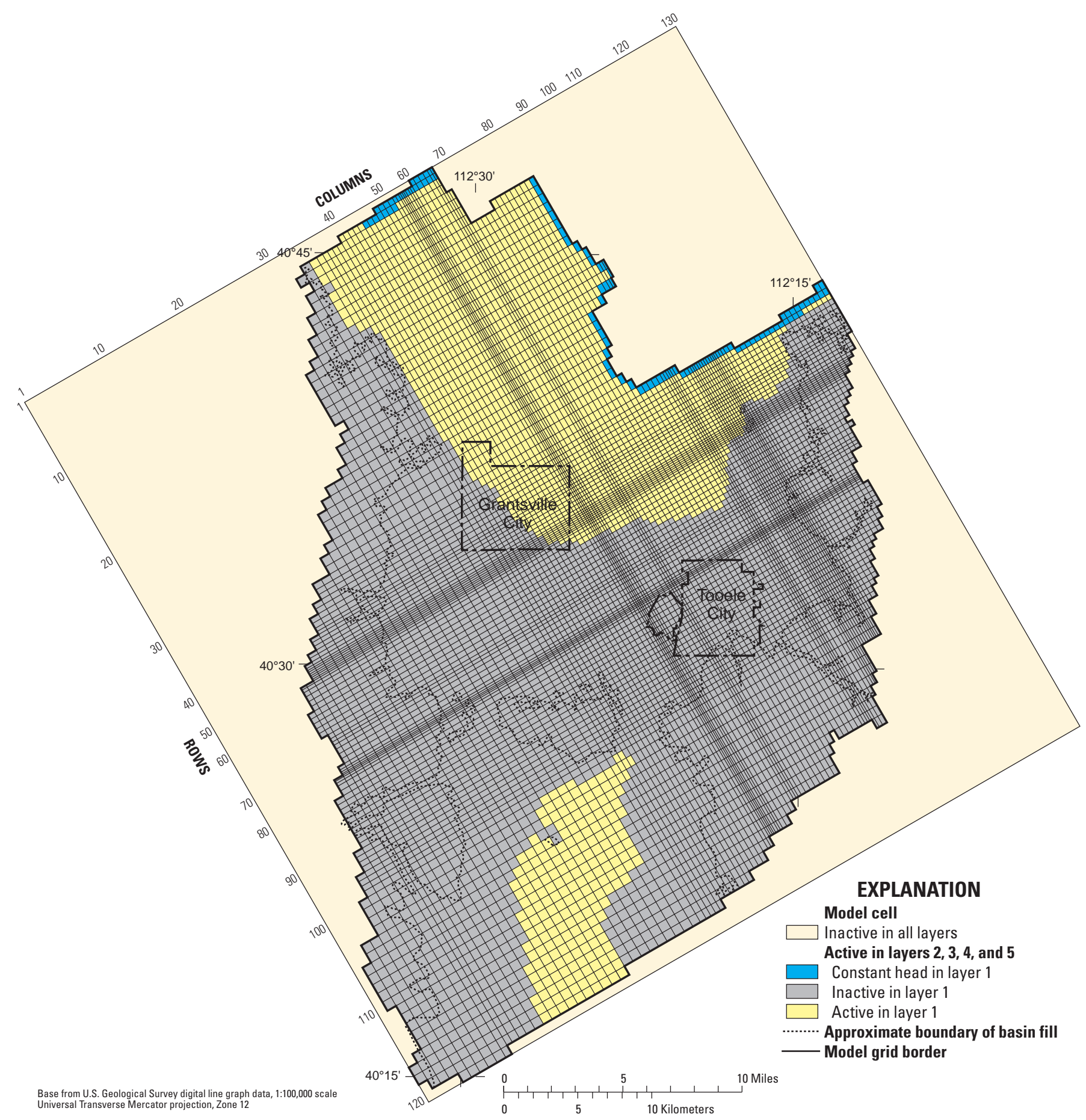

Figure 16. Model grid and location of active cells in the ground-water flow model, Tooele Valley ground-water basin, Tooele County, Utah.

MODFLOW-2000 requires that the top layer be assigned as a convertible layer, and the model automatically changes to confined conditions if the layer becomes fully saturated. To prevent the model from simulating unrealistic confined conditions, the top of model layer 1 was assigned an artificially high altitude of 7,000 ft instead of land-surface altitude at all locations, and the top of layer 2 was assigned an altitude of 10,000 $\mathrm{ft}$ where layer 1 is inactive.

\section{Temporal Discretization}

The model simulates both steady-state and transient conditions; a separate model does not exist for steady-state conditions. MODFLOW-2000 allows the first period in a transient simulation to be steady-state and the water levels from that period to be used as initial conditions for the transient stress periods. The steady-state period simulates recharge and discharge in 1968 and simulates March 1969 water levels 
(Lambert and Stolp, 1999, p. 19). Ground-water withdrawals and precipitation were equal to about the average for 1964-94 (Lambert and Stolp, 1999, fig. 8) and water levels were low, but fairly steady during this period (Lambert and Stolp, 1999, fig 9).

The transient period simulates 35 yearly stress periods from 1969 to 2003. Water levels measured in March or early April are used for calibration, and stress periods are assumed to be from March 1 to February 28. Water levels are used for those months because more data are available for those months and because the system is stressed less by withdrawals and recharge than during other times of the year. Water levels measured in March and early April are affected by the precipitation of the previous water year (October 1 to September 30). Precipitation in October through April either replenishes soil moisture or remains as snow and becomes recharge or runoff in May through July. This recharge and runoff plus precipitation from May to September affect March water levels the following year. Ground-water withdrawals also affect water levels measured the following March. Because peak withdrawals typically occur in July to September, using a March to February model time step incorporates the previous season's peak withdrawals and does not incorporate the current calendar year peak withdrawals that have not yet occurred. The simulated water levels are compared to the observed water levels for the next year. For example, March 2003 water levels are compared to the simulated water levels at the end of stress period 35 , which simulates recharge and discharge from March 1, 2002, to February 28, 2003. The model simulates annual and longer-term water-level fluctuations. Given the uncertainties in local ground-water recharge and pumping withdrawals, simulated annual fluctuations at specific points should be considered approximations.

\section{Distribution of Aquifer Characteristics}

The aquifer characteristics that control simulated water levels are horizontal hydraulic conductivity, vertical hydraulic conductivity, specific yield in model layers 1 and 2, and specific storage in model layers $2,3,4$, and 5 . The model allows aquifer characteristics to vary spatially by using parameters and multiplier and zone arrays (Harbaugh and others, 2000, p. 15). Multiplier arrays are used for properties that can vary in each model cell, such as recharge, and zone arrays are used for properties that are consistent throughout areas of the model, such as hydraulic conductivity.

\section{Horizontal Hydraulic Conductivity}

The horizontal hydraulic conductivity of the basin fill was initially based on the previously simulated hydraulic conductivity of the coarse deposits (Lambert and Stolp, 1999, fig. 17), but the value assigned to each zone was changed to represent the combined value of the coarse and fine portions of the basin fill. As a result of this change, most of the hydraulic-conductivity values presented in this report are smaller than those reported in Lambert and Stolp (1999). In general, calibrated hydraulic-conductivity values of the basin fill are largest in higher-altitude areas of the valleys and smallest near Great Salt Lake (fig. 17).

The addition of consolidated rock in the Oquirrh and Stansbury Mountains and under parts of the basin fill required that horizontal hydraulic conductivity of rock be added as a model parameter. Model layers are not defined as being in fill or in rock. Instead, each cell was assigned a fraction fill and fraction rock value; the values add to 1 . The altitude of the top of consolidated rock under valley fill was determined by subtracting the thickness of the basin fill (Lambert and Stolp, 1999, fig. 2) from land-surface altitude. Adjustments were made to the altitude of consolidated rock to account for new data from wells near the basin fill and consolidated-rock boundary and from Tooele Army Depot (U.S. Army Corps of Engineers, 2004, fig. 6). Less is known about the thickness of the basin fill in northern Rush Valley, and the altitude of the top of consolidated rock was estimated on the basis of descriptions in Hood and others (1969, p. 13-14).

Initial values of horizontal hydraulic conductivity in rock were assigned on the basis of values used by the U.S. Army Corps of Engineers (2004, table 2) and TriTechnics Corporation (1996, table 2). The values were adjusted during calibration (fig. 18).

The value of hydraulic conductivity at each cell is determined by using the following equation:

$$
K=\text { fractionfill } \times K_{\text {fil }}+\text { fractionrock } \times K_{\text {rock }}
$$

where

$\mathrm{K}$ is the hydraulic conductivity of the model cell, fractionfill is the percentage of the cell that consists of saturated basin fill,

$K_{\text {fill }}$ is the hydraulic conductivity of the basin fill,

fractionrock is the percentage of the cell that consists of consolidated rock, and

$\mathrm{K}_{\text {rock }}$ is the hydraulic conductivity of rock.

The hydraulic conductivity of basin fill and rock are defined as zones in MODFLOW-2000. The percentage of saturated basin fill and rock are defined as multiplier arrays in MODFLOW-2000. The calculation shown in equation 3 is performed internally in MODFLOW-2000 to determine horizontal hydraulic conductivity of each cell.

\section{Horizontal-Flow Barriers}

Observed water levels in many parts of the valley indicate distinct variability in the hydraulic gradient (fig. 6). Areas where the gradient steepens abruptly could not be simulated using only changes in hydraulic conductivity within model cells. In these areas, the Horizontal-Flow Barrier (HFB) package (Harbaugh and others, 2000, p. 63) is used to reduce the hydraulic conductivity between model cells and simulate the steep gradients (fig. 18). The HFB package allows hydraulic conductivity between cells to be decreased without affecting the hydraulic conductivity of the adjacent cells. MODFLOW-2000 allows the value of conductance across 


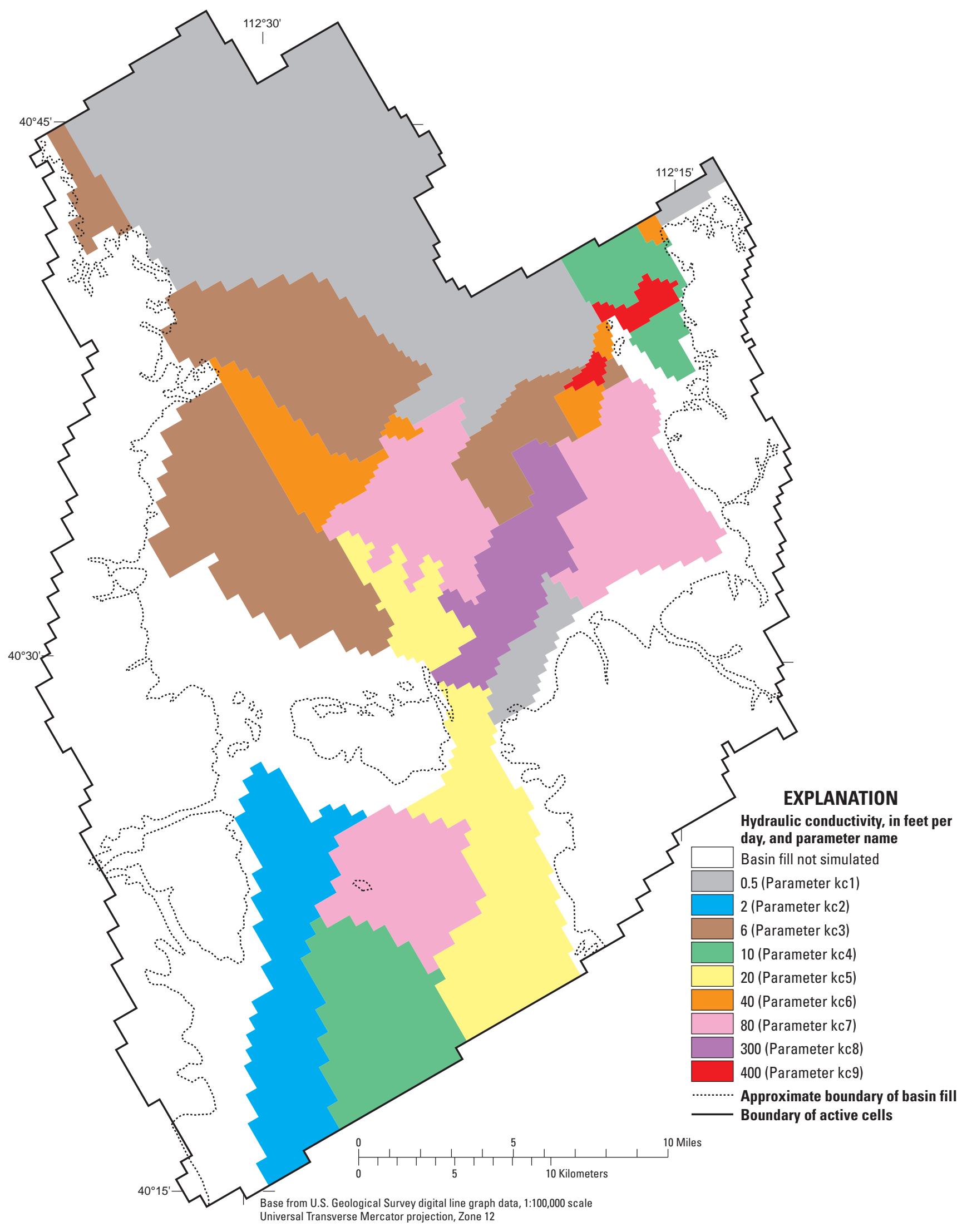

Figure 17. Final distribution of horizontal hydraulic-conductivity values and parameters of the basin fill as simulated in the groundwater flow model, Tooele Valley ground-water basin, Tooele County, Utah. 


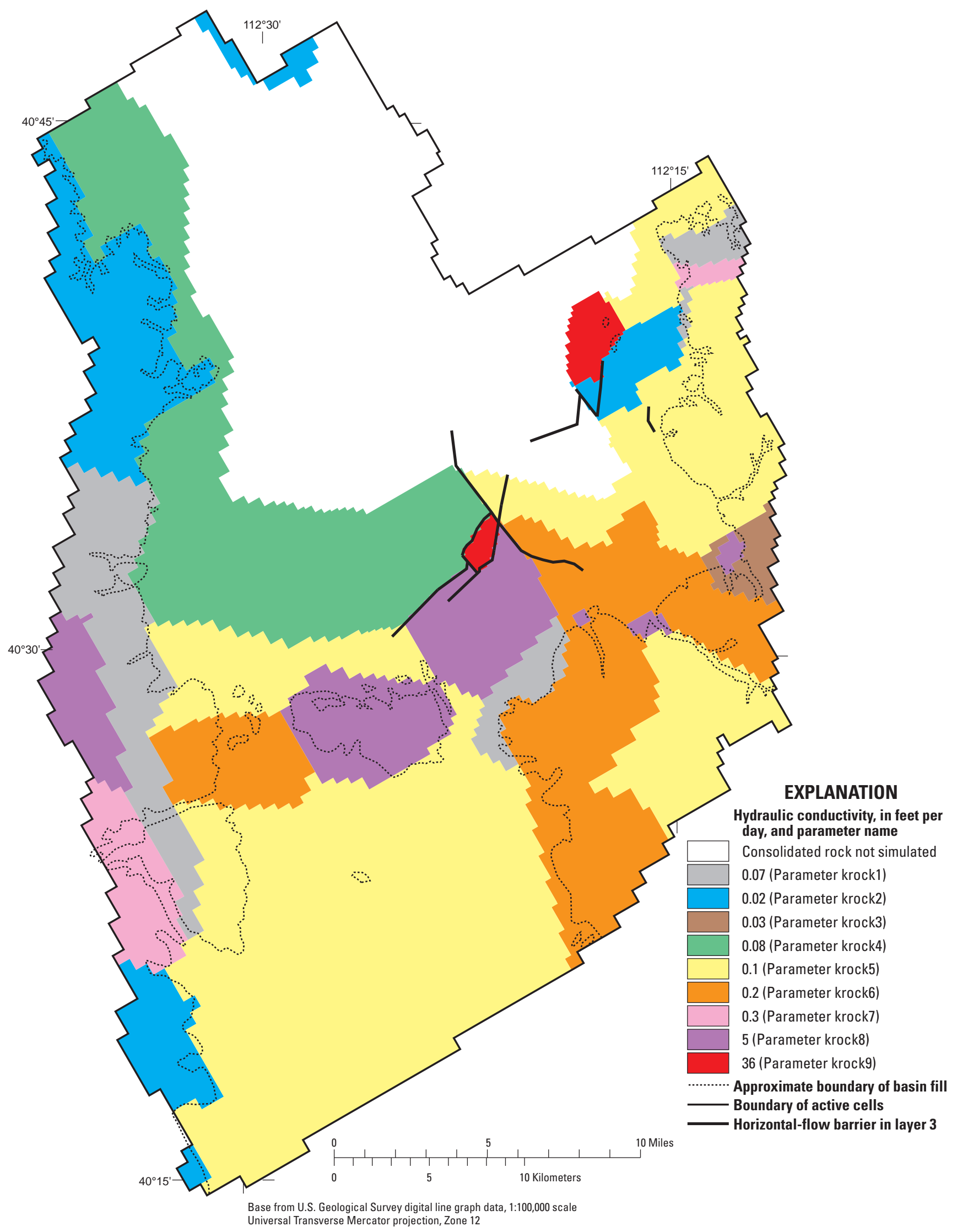

Figure 18. Final distribution of horizontal-flow barriers in layer 3 and hydraulic-conductivity values and parameters of consolidated rock as simulated in the ground-water flow model, Tooele Valley ground-water basin, Tooele County, Utah. 
the barrier to be defined as a parameter. For this simulation, the parameters (hfbtad1, hfbtad2, and hfberda) are hydraulic conductivity, in feet per day and the barriers are simulated as having widths of $1 \mathrm{ft}$. In the area of the TEAD, the simulated horizontal-flow barriers coincide with known or suspected faults (U.S. Army Corps of Engineers, 2004, fig. 2). These faults are simulated as individual cells of lower conductivity (U.S. Army Corps of Engineers, 2004, fig. 7), but that could not be done in this basin-scale model because the model cell size is too large. The presence of faults or other hydrostratigraphic features associated with the other areas of steep gradients have not been identified. The use of HFB in those areas does not imply a fault or a particular hydrostratigraphic feature, but only that the hydraulic conductivity is reduced across an area smaller than the model cell size.

\section{Vertical Hydraulic Conductivity}

Water-level measurements in some wells indicate vertical-head gradients within the unconsolidated basin fill. To simulate the measured vertical-head gradients, it was necessary for vertical hydraulic conductivity to be less than horizontal hydraulic conductivity in the model in those areas. To simulate discharge to the four large springs in the northern part of Tooele Valley, it was necessary that vertical conductivity elsewhere was lower than at the springs. The variation in vertical hydraulic conductivity is simulated with parameters and a zone array (Harbaugh and others, 2000, p. 60). The values of the parameters defining vertical hydraulic conductivity are the actual values of conductivity (fig. 19); no multiplier array is used.

\section{Specific Yield and Specific Storage}

Model layers 2, 3, 4, and 5 are assigned the same areal distribution of specific storage, and model layers 1 and 2 are assigned a similar distribution of specific yield. Specific storage is storage coefficient divided by the thickness of the confined layer. Model layer 2 requires that both specific yield and specific storage be defined because it is confined where layer 1 is active and unconfined elsewhere. The values of the parameters defining specific yield and specific storage (sy1, sy2, sy3, ss1, ss2, ss 3, ss4, ss5, ss6) are the actual simulated values (fig. 20); no multiplier array is used. Parameters ss1, ss 3 , and ss 5 are used only when layers 1 or 2 become confined during simulation in areas in which they are actually unconfined. This can occur for two reasons. The first reason is that MODFLOW-2000 does not define layers as unconfined, only as convertible. If the simulated water level rises above the top of the aquifer, specific storage will be used instead of specific yield. The second reason is that the layers may be intentionally set as confined for numerical stability and particle tracking.

When the model is used for sensitivity analysis, layer 2 must be defined as confined to prevent numerical instability. When the model is used for particle tracking, layers 1 and 2 must be defined as confined to allow proper calculation of velocity. These circumstances require specific storage to be defined as specific yield divided by layer thickness so that the solution was similar to the solution for unconfined conditions. When simulated as confined, the top of layer 2 where layer 1 is not active, and the top of layer 1 are defined as the altitude of the steady-state simulated water levels. If the layers are not redefined for particle tracking, the cross-sectional area used in velocity calculations is too large, causing calculated velocity to be too slow and calculated time-of-travel to be too large.

\section{Boundary Conditions}

The boundaries chosen for the model describe mathematically how the simulated ground-water system interacts with the surrounding hydrologic system. Mathematical boundaries that are used to represent hydrologic boundaries include no-flow boundaries, specified-flux boundaries, and head-dependent flux boundaries. These boundaries define the physical limits of the ground-water system and simulate recharge and discharge. No-flow boundaries are considered impermeable and no flow is simulated across them. Specifiedflux boundaries allow a specified rate of water through the cell and are used to simulate all recharge and some discharge in this model. Head-dependent flux boundaries simulate flow across the boundary proportional to the difference in heads across the boundary and are used to simulate most discharge in this model.

\section{No-Flow Boundaries}

The surface-water divides at the top of the Oquirrh and Stansbury Mountains and the ground-water divide in Rush Valley are simulated as no-flow boundaries and define the boundary of active cells (fig. 16). During natural, unstressed conditions, this assumption is considered valid for the top of the mountains because the relatively larger amount of recharge on mountains causes ground-water mounding and a natural ground-water divide near the ridge. No geologic features have been identified in these areas that would prevent water from moving from one side of the ridge to the other. The groundwater divide in Rush Valley is shallow and does not have a large recharge mound. Withdrawals and other man-made diversions near the surface-water divide in the mountains could cause the ground-water divide to shift away from the surface-water divide, as discussed in the "Mining Activities in the Oquirrh Mountains" section of this report. Increased ground-water withdrawals near the ground-water divide in Rush Valley could shift the location of that divide. Unconsolidated basin fill and consolidated rock constituting the base of the model domain below an altitude of 3,100 ft are considered no-flow boundaries because the active ground-water flow system probably does not extend deeper than that (Lambert and Stolp, 1999, p. 21).

\section{Recharge Boundaries}

Recharge is simulated from precipitation, streams, irrigation, and inflow from injection wells used by TEAD. Areal recharge from precipitation, streams, and irrigation is simulated as a specified-flux boundary with the Recharge Package 


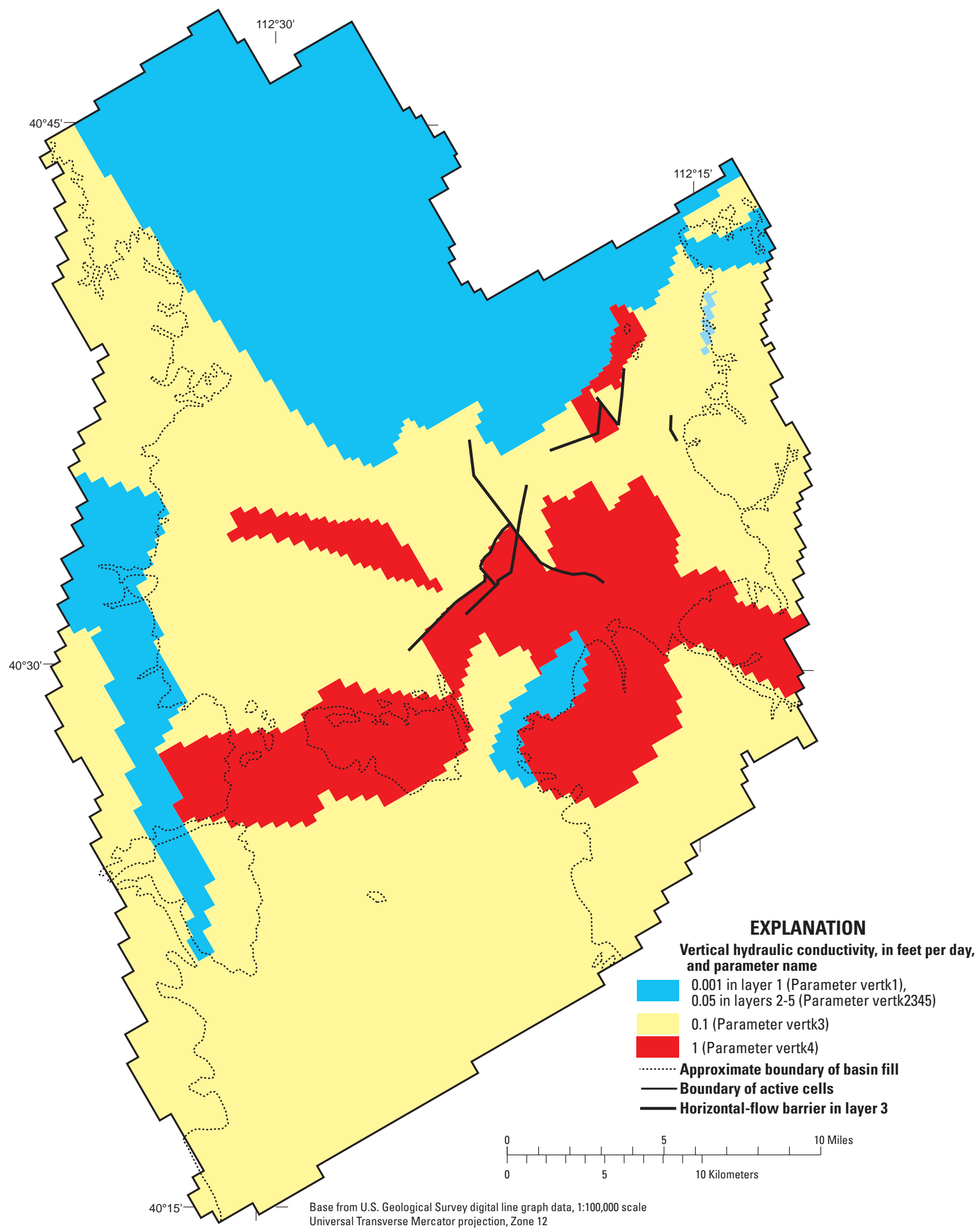

Figure 19. Final distribution of vertical hydraulic-conductivity values and parameters as simulated in the ground-water flow model, Tooele Valley ground-water basin, Tooele County, Utah. 


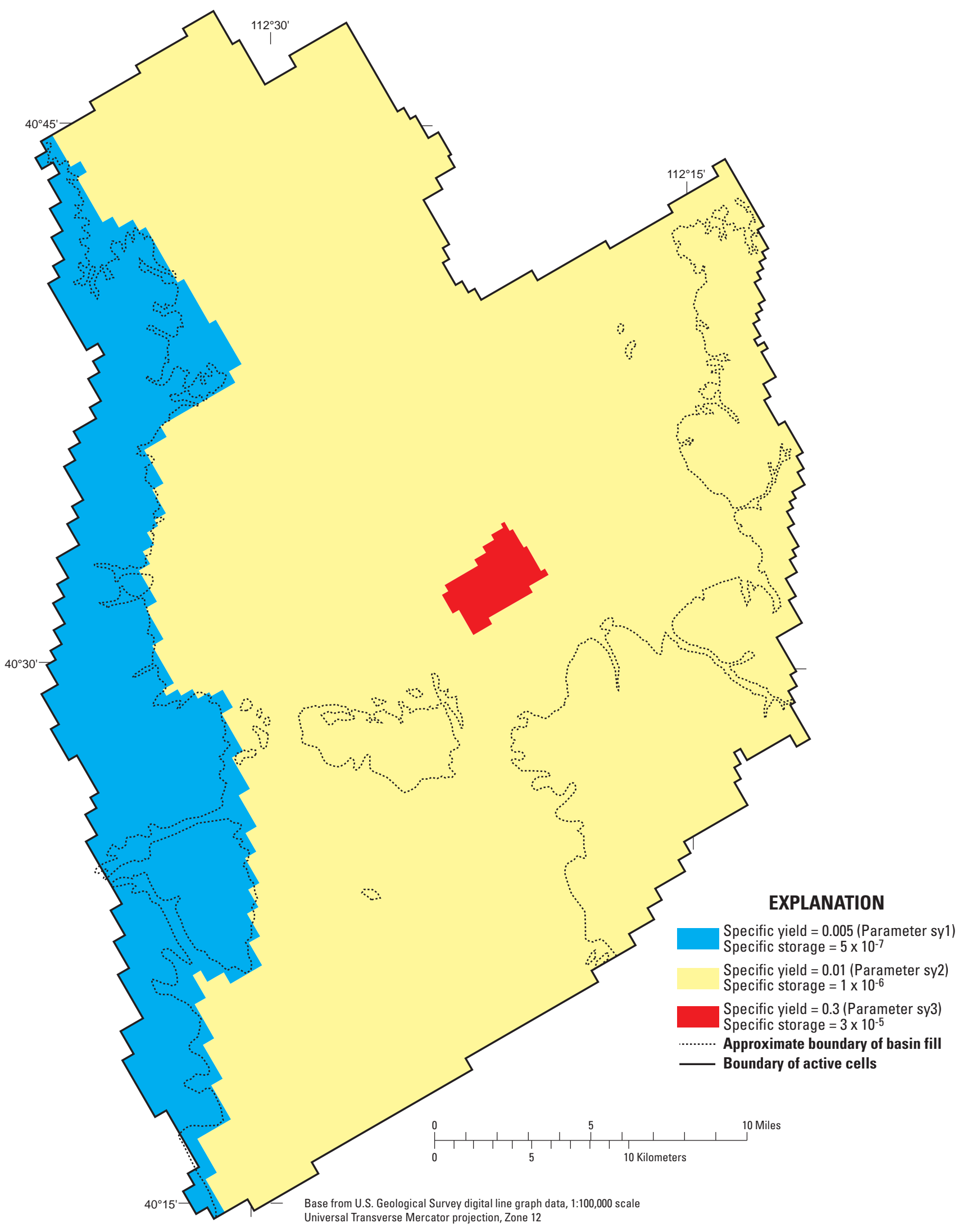

Figure 20. Final distribution of specific-yield and specific-storage values and parameters as simulated in the ground-water flow model, Tooele Valley ground-water basin, Tooele County, Utah. 
(Harbaugh and others, 2000, p. 67) and is applied to the highest active cell. Recharge from precipitation was distributed to approximate the conceptual recharge (table 7).

A multiplier array is used to distribute the 1971-2000 average annual recharge from precipitation across the study area (fig. 21). The simulated distribution of recharge across the study area was based on precipitation contours (fig. 3) and the amount of recharge in each drainage basin. The amount of recharge as a percentage of precipitation was adjusted for each precipitation amount and each location to match the conceptual recharge (table 7). The percentage of precipitation that becomes recharge was kept as consistent as possible within precipitation ranges. More recharge occurs in the Oquirrh Mountains than on the Stansbury Mountains, even though the Stansbury Mountains receive more precipitation (table 3).

The MODFLOW-2000 Recharge Package allows the value of recharge flux to be defined using one or more parameters (Harbaugh and others, 2000, p. 68). In this model, the multiplier array defines the conceptual recharge rate at each cell in feet per year, and the recharge parameters multiply the conceptual recharge by a constant value to convert the rate to feet per day. Five recharge parameters are defined for recharge from precipitation (rech1, rech2, rech3, rech4, and rech5). Each recharge parameter was set equal to 0.002738 (conversion from feet per year to feet per day) to simulate conceptual recharge and was not changed during calibration.

The 1971-2000 multiplier array was scaled to vary the amount of recharge from precipitation on an annual basis during simulation (table 8). The scaling factor is based on the annual flow at the USGS gaging station 10172800, South Willow Creek near Grantsville City, Utah. This is the only stream in the basin with long-term flow records that can be used to estimate streamflow and recharge variability with precipitation. Recharge from precipitation was assumed to vary by the same proportion as streamflow in South Willow Creek. This assumes that variation of the amount of water used by vegetation is insignificant from year to year; therefore, more water is available for both runoff and recharge in years with more precipitation. The annual fraction of average streamflow was sorted and grouped from lowest to highest; 17 scaling factors can be used to represent all years of the transient simulation and are defined as parameter instances in the Recharge Package (see Time-varying-parameters.pdf, included with MODFLOW-2000 distribution, Harbaugh and others, 2000). The distribution of recharge from precipitation was constant during the simulation; all recharge amounts vary by the same factor to create the change in annual recharge. The scaling factors are defined in the multiplier file for MODFLOW-2000 (Harbaugh and others, 2000, p. 47-48).

Recharge from irrigation was initially distributed the same as in the previous model (Lambert and Stolp, 1999, p. 30). Recharge from irrigation was added to a small part of northern Rush Valley to simulate recharge from irrigation with ground water. Recharge from irrigation with surface water in northern Rush Valley is simulated as recharge from stream loss as those streams are used and diverted across the area. A multiplier array is used to define the conceptual recharge rate
Table 7. 1971-2000 average annual conceptual recharge from precipitation and simulated recharge from precipitation, Tooele Valley ground-water basin, Tooele County, Utah.

[All amounts in rounded acre-feet]

\begin{tabular}{lcc}
\hline \multicolumn{1}{c}{ Location } & $\begin{array}{c}\text { Conceptual recharge } \\
\text { from precipitation } \\
\text { (from table 3) }\end{array}$ & $\begin{array}{c}\text { Simulated recharge } \\
\text { from precipitation }\end{array}$ \\
\hline North Stansbury Mountains & 1,700 & 2,000 \\
\hline Warm Springs Slough & 2,500 & 2,300 \\
\hline North Willow Creek & 3,300 & 3,400 \\
\hline South Willow Creek & 4,300 & 4,500 \\
\hline Box Elder Wash & 6,500 & 6,400 \\
\hline Total Stansbury Mountains & $\mathbf{1 8 , 3 0 0}$ & $\mathbf{1 8 , 6 0 0}$ \\
\hline Silcox Canyon & 2,100 & 1,100 \\
\hline Settlement Canyon & 9,600 & 9,300 \\
\hline Middle, Pine, and Pass Canyons & 14,500 & 14,300 \\
\hline Bates Canyon & 2,700 & 2,900 \\
\hline Lake Point & 4,900 & 4,700 \\
\hline Sixmile Creek & 200 & 300 \\
\hline Total Oquirrh Mountains & $\mathbf{3 4 , 0 0 0}$ & $\mathbf{3 2 , 6 0 0}$ \\
\hline Low-altitude parts of Tooele Valley & Included & 1,400 \\
\hline Total Tooele Valley & $\mathbf{5 2 , 3 0 0}$ & $\mathbf{5 2 , 6 0 0}$ \\
\hline Hickman Creek & 6,100 & 6,000 \\
\hline Clover Creek & 700 & 1,400 \\
\hline South of Clover Creek & & 700 \\
\hline Southport Gulch & 200 & 500 \\
\hline Soldier Creek & 400 & 6,300 \\
\hline Dry Canyon & 6,600 & 2,100 \\
\hline Rush Lake & 2,000 & 800 \\
\hline Low-altitude parts of Rush Valley & Included & 700 \\
\hline Total northern Rush Valley & $\mathbf{1 6 , 7 0 0}$ & $\mathbf{1 8 , 5 0 0}$ \\
\hline Total study area & $\mathbf{6 9 , 0 0 0}$ & $\mathbf{7 1 , 1 0 0}$ \\
\hline & & \\
\hline
\end{tabular}

' Conceptual recharge from precipitation is determined for entire drainage areas, including low-altitude parts of Tooele and Rush Valleys. The numerical model budget accounts the recharge from precipitation in the low-altitude parts of the valleys separately from recharge in the mountains.

${ }^{2}$ Estimated baseflow in Clover Creek exceeds recharge from precipitation. The simulated recharge was increased to match estimated baseflow.

Simulated recharge increased to match simulated recharge rates in Clover Creek drainage basin.

from irrigation at each cell in feet per year, and the recharge parameters multiply the conceptual recharge by a constant value of 0.002738 to convert the rate from feet per year to feet per day. The multiplier array defining conceptual irrigation recharge rates was not adjusted during calibration. Four recharge parameters are defined for recharge from irrigation (tbirr, grantsirr, rechirr1, and carrfork). The four irrigation recharge parameters are specifically assigned to four irrigation zones (fig. 22) that represent areas with different recharge scenarios in the conceptual budget.

The parameter tbirr applies to the bench area near and east of Tooele that is irrigated by surface water from Middle and Settlement Canyons as discussed in the "Irrigation" section of this report. Parameter instances are associated with scaling factors that cause recharge from irrigation in this area to vary in each stress period by 0.2 to 8.2 times the specified 


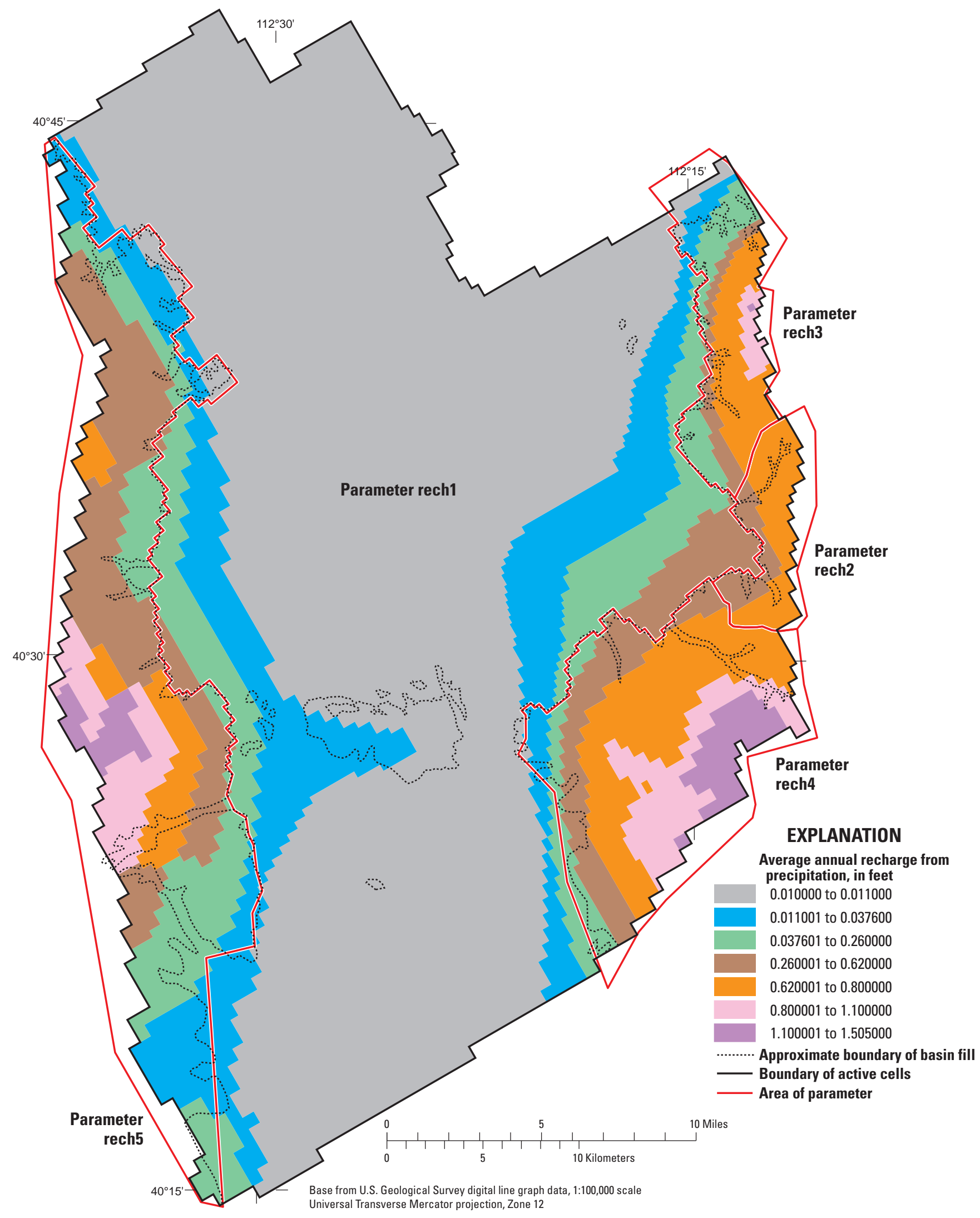

Figure 21. Areas of recharge parameters for precipitation and average annual recharge from precipitation simulated in the groundwater flow model, Tooele Valley ground-water basin, Tooele County, Utah. 
Table 8. Annual recharge from precipitation, Tooele Valley ground-water basin, Tooele County, Utah.

[SS, steady-state period; NS, time period not simulated]

\begin{tabular}{|c|c|c|c|c|c|}
\hline \multirow[t]{2}{*}{$\begin{array}{l}\text { Water } \\
\text { year }\end{array}$} & \multicolumn{2}{|c|}{$\begin{array}{c}\text { USGS gaging station } \\
10172800 \\
\text { South Willow Creek near } \\
\text { Grantsville, Utah }\end{array}$} & \multirow{2}{*}{$\begin{array}{l}\text { Name of } \\
\text { model } \\
\text { parameter } \\
\text { instance }\end{array}$} & \multirow{2}{*}{$\begin{array}{l}\text { Average } \\
\text { scaling } \\
\text { factor for } \\
\text { instance }\end{array}$} & \multirow{2}{*}{$\begin{array}{c}\text { Concep- } \\
\text { tual } \\
\text { recharge } \\
\text { (acre- } \\
\text { feet) }\end{array}$} \\
\hline & $\begin{array}{c}\text { Flow } \\
\text { (acre-feet) }\end{array}$ & $\begin{array}{c}\text { Fraction of } \\
1971-2000 \\
\text { average }\end{array}$ & & & \\
\hline 1968 & 4,200 & 0.83 & SS & 0.83 & 71,607 \\
\hline 1969 & 5,600 & 1.09 & 10 & 1.1 & 94,901 \\
\hline 1970 & 4,700 & 0.93 & 8 & 0.917 & 79,113 \\
\hline 1971 & 5,300 & 1.04 & 9 & 1.02 & 87,999 \\
\hline 1972 & 4,700 & 0.92 & 8 & 0.917 & 79,113 \\
\hline 1973 & 6,087 & 1.19 & 11 & 1.19 & 102,666 \\
\hline 1974 & 4,348 & 0.85 & 7 & 0.85 & 73,333 \\
\hline 1975 & 6,377 & 1.25 & 12 & 1.28 & 110,431 \\
\hline 1976 & 3,971 & 0.78 & 6 & 0.77 & 66,431 \\
\hline 1977 & 2,391 & 0.47 & 1 & 0.46 & 39,686 \\
\hline 1978 & 4,573 & 0.90 & 8 & 0.917 & 79,113 \\
\hline 1979 & 3,971 & 0.78 & 6 & 0.77 & 66,431 \\
\hline 1980 & 7,102 & 1.39 & 13 & 1.39 & 119,921 \\
\hline 1981 & 3,181 & 0.62 & 3 & 0.618 & 53,317 \\
\hline 1982 & 6,080 & 1.19 & 11 & 1.19 & 102,666 \\
\hline 1983 & 8,406 & 1.65 & 15 & 1.635 & 141,058 \\
\hline 1984 & 10,797 & 2.12 & 16 & 2.12 & 182,901 \\
\hline 1985 & 5,160 & 1.01 & 9 & 1.02 & 87,999 \\
\hline 1986 & 7,536 & 1.48 & 14 & 1.47 & 126,823 \\
\hline 1987 & 3,819 & 0.75 & 6 & 0.77 & 66,431 \\
\hline 1988 & 2,674 & 0.52 & 2 & 0.533 & 45,984 \\
\hline 1989 & 3,174 & 0.62 & 3 & 0.618 & 53,317 \\
\hline 1990 & 2,341 & 0.46 & 1 & 0.46 & 39,686 \\
\hline 1991 & 3,486 & 0.68 & 5 & 0.68 & 58,666 \\
\hline 1992 & 2,312 & 0.45 & 1 & 0.46 & 39,686 \\
\hline 1993 & 5,152 & 1.01 & 9 & 1.02 & 87,999 \\
\hline 1994 & 3,167 & 0.62 & 3 & 0.618 & 53,317 \\
\hline 1995 & 7,464 & 1.46 & 14 & 1.47 & 126,823 \\
\hline 1996 & 5,631 & 1.10 & 10 & 1.1 & 94,901 \\
\hline 1997 & 6,660 & 1.31 & 12 & 1.28 & 110,431 \\
\hline 1998 & 8,261 & 1.62 & 15 & 1.635 & 141,058 \\
\hline 1999 & 5,652 & 1.11 & 10 & 1.1 & 94,901 \\
\hline 2000 & 3,283 & 0.64 & 4 & 0.64 & 55,215 \\
\hline 2001 & 3,254 & 0.64 & 4 & 0.64 & 55,215 \\
\hline 2002 & 2,783 & 0.55 & 2 & 0.533 & 45,984 \\
\hline 2003 & 2,710 & 0.53 & 2 & 0.533 & 45,984 \\
\hline 2004 & 3,109 & 0.61 & NS & 0.61 & 52,627 \\
\hline $\begin{array}{l}1971- \\
2000 \\
\text { average }\end{array}$ & 5,103 & 1.00 & & 1.00 & 86,277 \\
\hline $\begin{array}{l}1964- \\
2004 \\
\text { average }\end{array}$ & 4,812 & 0.94 & & 0.95 & 81,993 \\
\hline
\end{tabular}




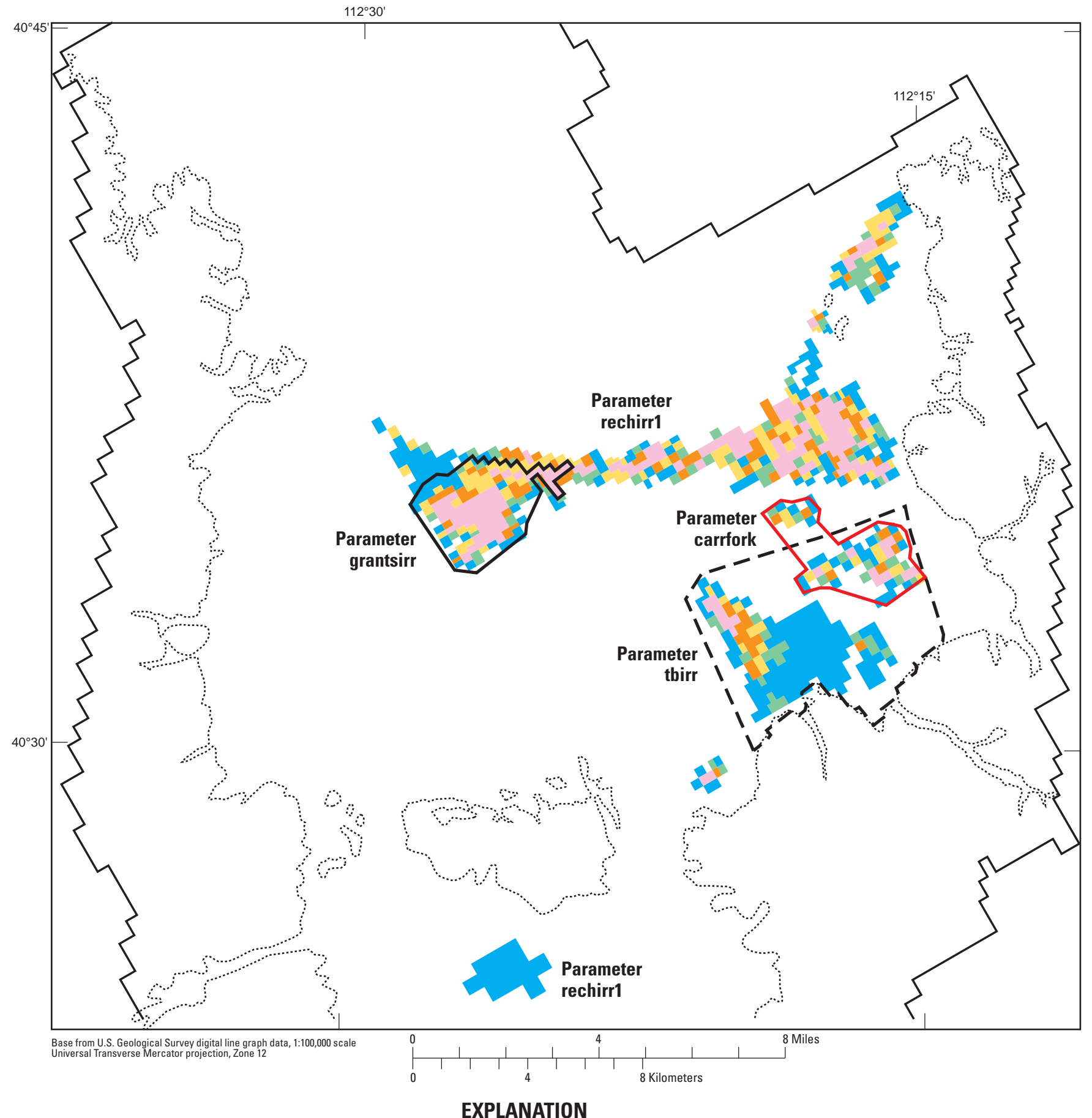

Multiplier array for recharge from irrigation, in feet per year

\begin{tabular}{|c|c|c|c|}
\hline & 0 & 0.19 to 0.30 & 0.41 to 0.459 \\
\hline & 0.01 to 0.18 & 0.31 to 0.40 & 0.46 \\
\hline \multicolumn{3}{|c|}{ Zone of time-varying recharge } & Carr Fork \\
\hline
\end{tabular}

Figure 22. Zones of time-varying recharge from irrigation, area of irrigation with Carr Fork water during selected years, and multiplier array for recharge from irrigation simulated in the ground-water flow model, Tooele Valley ground-water basin, Tooele County, Utah. 


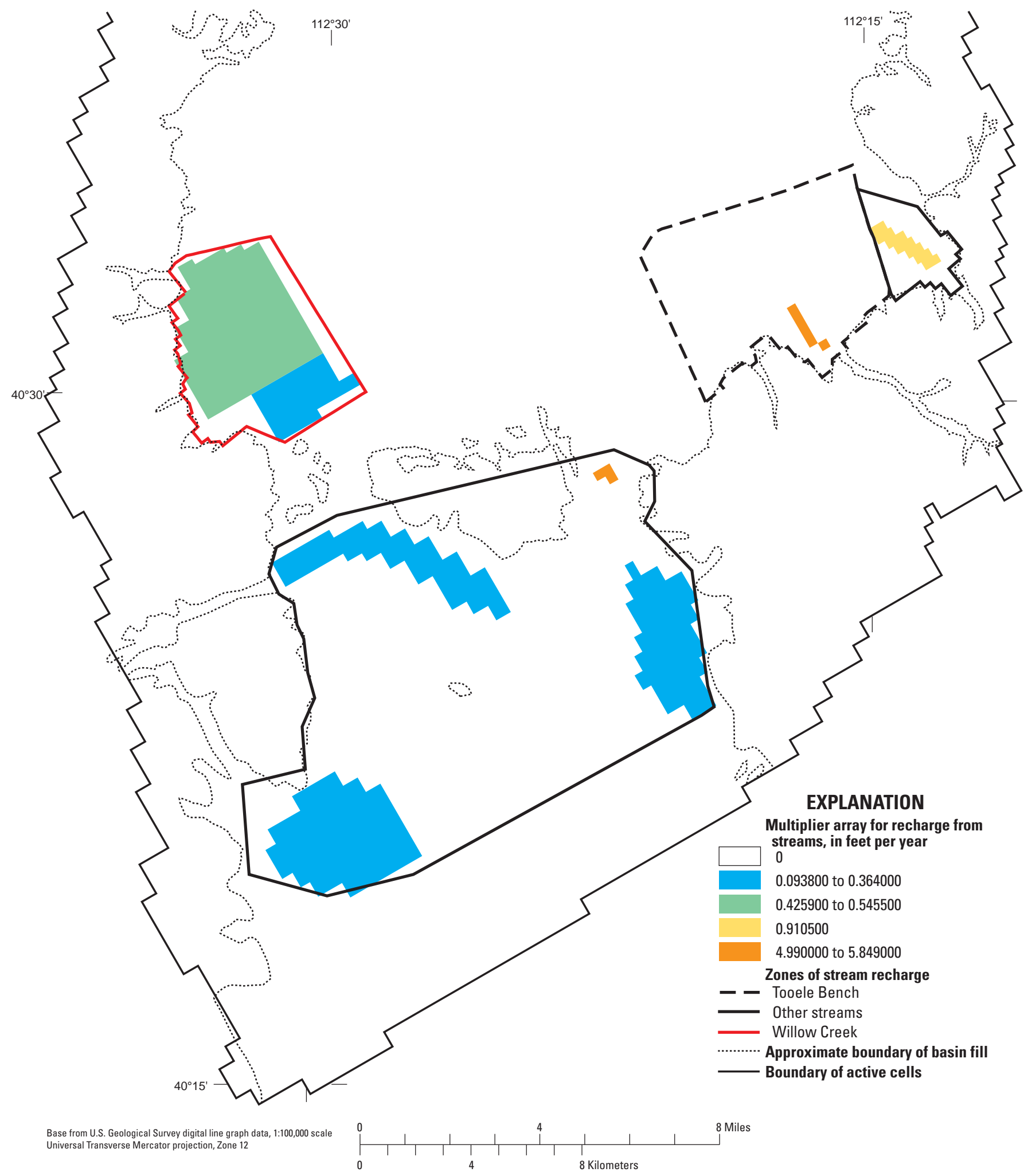

Figure 23. Recharge zones and average annual recharge from stream infiltration simulated in the ground-water flow model, Tooele Valley ground-water basin, Tooele County, Utah. 
parameter willowstrm defines the amount of recharge in this area and converts the values to feet per day.

Recharge from streams in Clover, Soldier, and Hickman Canyons in northern Rush Valley also was distributed over large areas to account for stream recharge and irrigation with stream water. The same scaling factors (table 8) used for recharge from precipitation are used to vary recharge from these streams during simulation. Recharge from the Pine Canyon area also is simulated this way. The model parameter rushstrm defines the amount of recharge in these two areas and converts the values to feet per day.

Recharge from the stream in Middle Canyon was concentrated at the mouth of the canyon upstream of major diversions. Water in Settlement Canyon is typically diverted to pipelines and recharge from streams in this area is not simulated. Because the amount of water diverted from springs in Middle Canyon by Tooele City varies yearly, the annual scaling factor for recharge from Middle Canyon Creek is slightly different than the scaling factor used for recharge from precipitation and other streams. The model parameter middlestrm defines the amount of recharge in this area and converts the values to feet per day.

Streams in the mountain areas are simulated using the Stream Package (Prudic, 1989) to simulate discharge from the ground-water system to baseflow in the streams. The Stream Package, however, simulates both recharge and discharge (depending on the difference between simulated water level and stream altitude); therefore, these boundary conditions are discussed further in the next section on "Discharge Boundaries."

Recharge from TEAD injection wells is simulated using the Well Package with rates provided by TEAD (Carl Cole, TEAD, written commun., September 26, 2005).

\section{Discharge Boundaries}

Discharge is simulated to evapotranspiration, springs, wells, streams, and Great Salt Lake. Discharge to evapotranspiration, springs, streams, and Great Salt Lake is head dependent. In the steady-state period, the sum of these discharge components is equal to the simulated recharge (most of which is specified-flux recharge) minus well withdrawal. Possible diversion of ground water from the Tooele Valley groundwater basin to adjacent mining areas (see "Mining Activities in the Oquirrh Mountains" section of this report) is simulated as negative recharge over the Pass and Pine Canyon areas (fig. 24). Because this model was not constructed to simulate flow to mine workings in the area, discharge related to Kennecott mining activities could not be accurately simulated. Reducing recharge will not yield simulated water levels that match tunnel and shaft water levels near Kennecott, but should yield simulated water levels in basin fill in Tooele Valley and simulated discharge to springs that reflect the possible diversion of water from the ground-water basin.

Discharge to evapotranspiration is simulated in layer 1 with the Evapotranspiration Package (Harbaugh and others, 2000, p. 73). The rate of evapotranspiration simulated depends on the maximum evapotranspiration rate, the depth below land surface at which transpiration stops (extinction depth), and the simulated ground-water level (McDonald and Harbaugh, 1988, fig. 42). Data required for the Evapotranspiration Package are the altitude of the evapotranspiration surface, extinction depth, and the maximum evapotranspiration rate. The altitude of the evapotranspiration surface was estimated as land surface from USGS 1:24,000-scale topographic maps and 10-meter resolution Digital Elevation Models (DEM; National Elevation Dataset, 2004). In most areas of evapotranspiration, the error associated with the altitude estimate is 5 to $10 \mathrm{ft}$. An extinction depth of $15 \mathrm{ft}$ was used for all areas of evapotranspiration (Lambert and Stolp, 1999, p. 32). Areas of evapotranspiration in Tooele Valley are the same as those used in the simulation by Lambert and Stolp (1999, fig. 15 and table 7), but the maximum rate was reduced from 2.67 to $1.6 \mathrm{ft} / \mathrm{yr}$ to account for some of the water demand being supplied by precipitation and surface-water accumulation. This rate is slightly higher than the highest rate in table 6, but the maximum simulated rate would only occur if the simulated water level was at or above land surface. The area of evapotranspiration in northern Rush Valley is similar to that reported by Hood and others (1969, pl. 1). Hood and others $(1969$, p. 28) assumed that evapotranspiration of ground water could occur where the depth to water was less than $50 \mathrm{ft}$. Because the simulated extinction depth is $15 \mathrm{ft}$, many of the areas delineated by Hood and others $(1969$, pl. 1) do not have simulated evapotranspiration. The older land use data and coarse delineation of vegetation type in Rush Valley precluded a detailed analysis of the maximum rate of evapotranspiration at the time of model calibration. The maximum rate of evapotranspiration, therefore, was assigned as $1.37 \mathrm{ft} / \mathrm{yr}$ in all areas of evapotranspiration in northern Rush Valley. This rate was used for salt grass by Lambert and Stolp (1999, table 7) in Tooele Valley and represents the mid-range of values used in Tooele Valley.

The maximum rate of evapotranspiration was assigned to each model cell using a multiplier array. The MODFLOW-2000 Evapotranspiration Package allows the value of maximum evapotranspiration flux to be defined using a parameter (Harbaugh and others, 2000, p. 74). The evapotranspiration parameter (etrate) used in this model multiplies the maximum rate of evapotranspiration by a constant value and converts the rate from feet per year to feet per day. Input to the Evapotranspiration Package was not changed during the transient periods, but the rate of evapotranspiration varies as simulated water levels vary. The simulated areas of evapotranspiration from ground water are very similar to the areas used to determine the conceptual water budget (fig. 10). An extinction depth of $15 \mathrm{ft}$ is used in the model and the conceptual budget included evapotranspiration in areas where the water is as much as $20 \mathrm{ft}$ below land surface; the value of extinction depth creates little difference in the simulated budgets. Very few model cells in the evapotranspiration areas have a water level of between 15 and $20 \mathrm{ft}$ below land surface, so the difference in area of simulated evapotranspiration is negligible.

Discharge to Factory-Dunne Springs, Mill Pond Springs, Warm Springs, and springs at the north end of the Oquirrh and Stansbury Mountains (fig. 25) is simulated in model layer 1 with the Drain Package (Harbaugh and others, 2000, p. 71). 


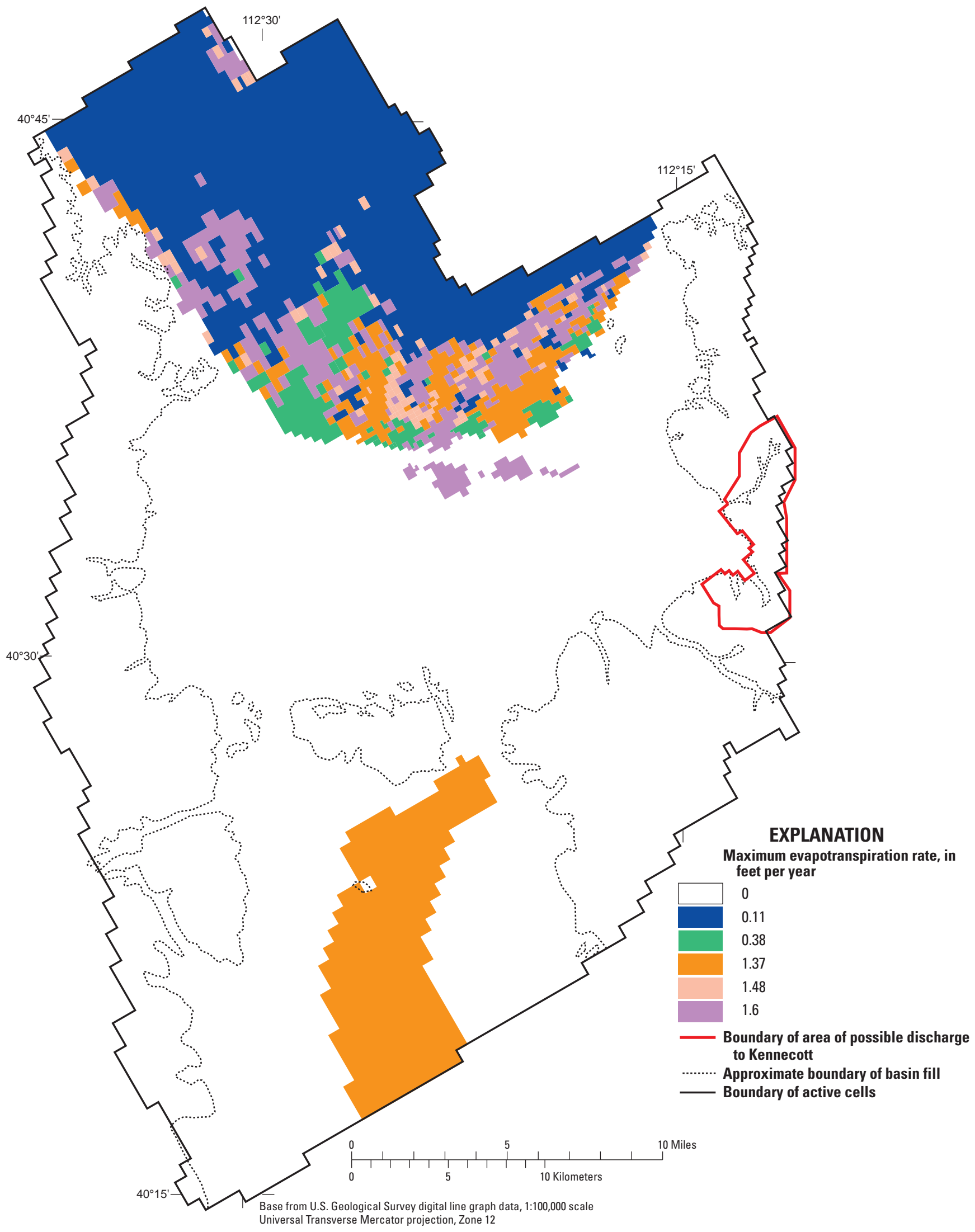

Figure 24. Maximum evapotranspiration rate and area of possible discharge to adjacent mining areas simulated in the ground-water flow model, Tooele Valley ground-water basin, Tooele County, Utah. 
Discharge to Rose Springs is simulated in model layer 2 with the Drain Package. The Drain Package simulates a headdependent flux boundary for each cell to which it is assigned, and discharge is a function of simulated water level and drain conductance (McDonald and Harbaugh, 1988, fig. 41). Data required for the Drain Package are altitude and conductance of the drain. MODFLOW-2000 allows conductance to be defined both by a conductance multiplier at each drain and by a parameter. Discharge to stream channels and ditches in layer 1 in the northern part of Tooele Valley also is simulated using the Drain Package as in Lambert and Stolp (1999, p. 32). The parameter drain multiplies the conductance of each drain by a constant value and converts the hydraulic conductivity from feet per second to feet per day. Input to the Drain Package was not changed during the transient simulation, but discharge to drains varies as simulated water levels vary.

Discharge to Fishing Creek and Sixmile Creek are simulated in model layer 1 with the Stream Package (Prudic, 1989) because the Stream Package allows variation of altitude along the length of the springs. Discharge to Big Springs (Pine Canyon) is simulated in layer 2 with the Stream Package because other consolidated-rock discharge in the mountains is simulated with the Stream Package and because part of the spring discharge may be underflow along the stream channel.

Discharge to pumping wells is simulated in all layers with the Well Package (Harbaugh and others, 2000, p. 69). The Well Package simulates a specified-flux boundary in each cell to which a well is assigned. Data required for the Well Package are the withdrawal rate in each layer. The distribution of withdrawal among layers in each well was determined prior to input into MODFLOW-2000. MODFLOW-2000 allows the value of the volumetric recharge rate (discharge is entered as a negative recharge rate) from wells to be defined using one or more parameters (Harbaugh and others, 2000, p. 70). Two MODFLOW-2000 parameters were defined for discharge to wells (parameters pumpage and tadpump).

Ground-water withdrawal for individual wells is needed for the steady-state simulation and for each annual stress period in the transient simulation. Withdrawals for wells from 1968 to 1994 were determined from unpublished data files of the previous simulation (Lambert and Stolp, 1999). Withdrawal rates for wells from 1994 to 2003 were obtained from the Utah Department of Natural Resources, Division of Water Rights, for public supply and industrial wells and from unpublished records of the USGS for irrigation wells. Simulated ground-water withdrawals range from a minimum of about 7,300 acre-ft in 1983 to a maximum of about 20,100 acre-ft in 1981.

In addition to withdrawals for public supply and irrigation, TEAD began withdrawing water in 1994, treating the water to remove solvents, and injecting the treated water into the ground-water system north of the depot. From 1999 to 2003, TEAD withdrew, treated, and injected an average of 7,600 acre-ft/yr. Withdrawal and injection rates for each well were obtained from TEAD for 1999-2003. The average rates for those years were used for 1994-1998.
In areas with few domestic wells and with septic tanks that may recharge the ground-water system, domestic withdrawals are not simulated. In the Lake Point area, however, the high density of domestic wells and the use of a municipal sewer system instead of septic tanks have the possibility of affecting ground-water levels in the area. Withdrawal from domestic wells in the Lake Point area was estimated to be about $170 \mathrm{acre}-\mathrm{ft} / \mathrm{yr}$, on the basis of the number of houses and the average use of 1 acre-ft/yr per house.

Discharge to flowing wells is simulated as head-dependent boundaries in layer 2 using the Drain Package (Harbaugh and others, 2000, p. 71). MODFLOW-2000 allows the value of the drain conductance to be defined as one or more parameters (Harbaugh and others, 2000, p. 72). Two MODFLOW-2000 parameters were defined for drain conductance. In most areas, the parameter flowing was used and drain conductance in each cell was the same as in the previous model (Lambert and Stolp, 1999, p. 32). In the area near Erda and Stansbury Park, however, using the drain conductance from the previous model allowed simulated discharge to be much greater than the measured discharge of about 900 acre-ft in 2005. The area (fig. 26) was assigned the parameter erda, which, when adjusted during calibration, made the simulated discharge of flowing wells in that area about 95 percent of the measured discharge.

Discharge to streams in the mountains (fig. 25) is simulated as a head-dependent boundary in layer 2 with the Stream Package (Prudic, 1989). Data needed for the Stream Package includes streambed altitude and streambed conductance. Streambed altitude was estimated to equal land-surface altitude as determined from DEMs. Streambed conductivity was adjusted during calibration. Streams are simulated in Pine Canyon, Middle Canyon, Settlement Canyon, North Willow Canyon, South Willow Canyon, Box Elder Canyon, Hickman Canyon, Clover Canyon, and Soldier Canyon. Discharge to the Honerine Tunnel near Stockton is also simulated using the Stream Package. Because few water levels are available in consolidated rock in the mountains, the ability of the model to simulate discharge to streams was used to provide some method of judging the accuracy of the model in consolidated rock.

Discharge to Great Salt Lake is simulated by assigning model cells in layer 1 at the lake boundary as constant-head cells with an altitude of 4,200 ft (Lambert and Stolp, 1999, p. 35). The higher density of Great Salt Lake water than of ground water is not simulated, but causes little difference in water levels (Lambert and Stolp, 1999, p. 35).

\section{Model Calibration}

The purpose of calibration is to develop a model that reasonably represents ground-water recharge, movement, and discharge; reasonably matches measured water levels; and represents where the differences between simulated and measured water levels and flows are acceptable for the intended use of the model. This model has been developed to simulate 


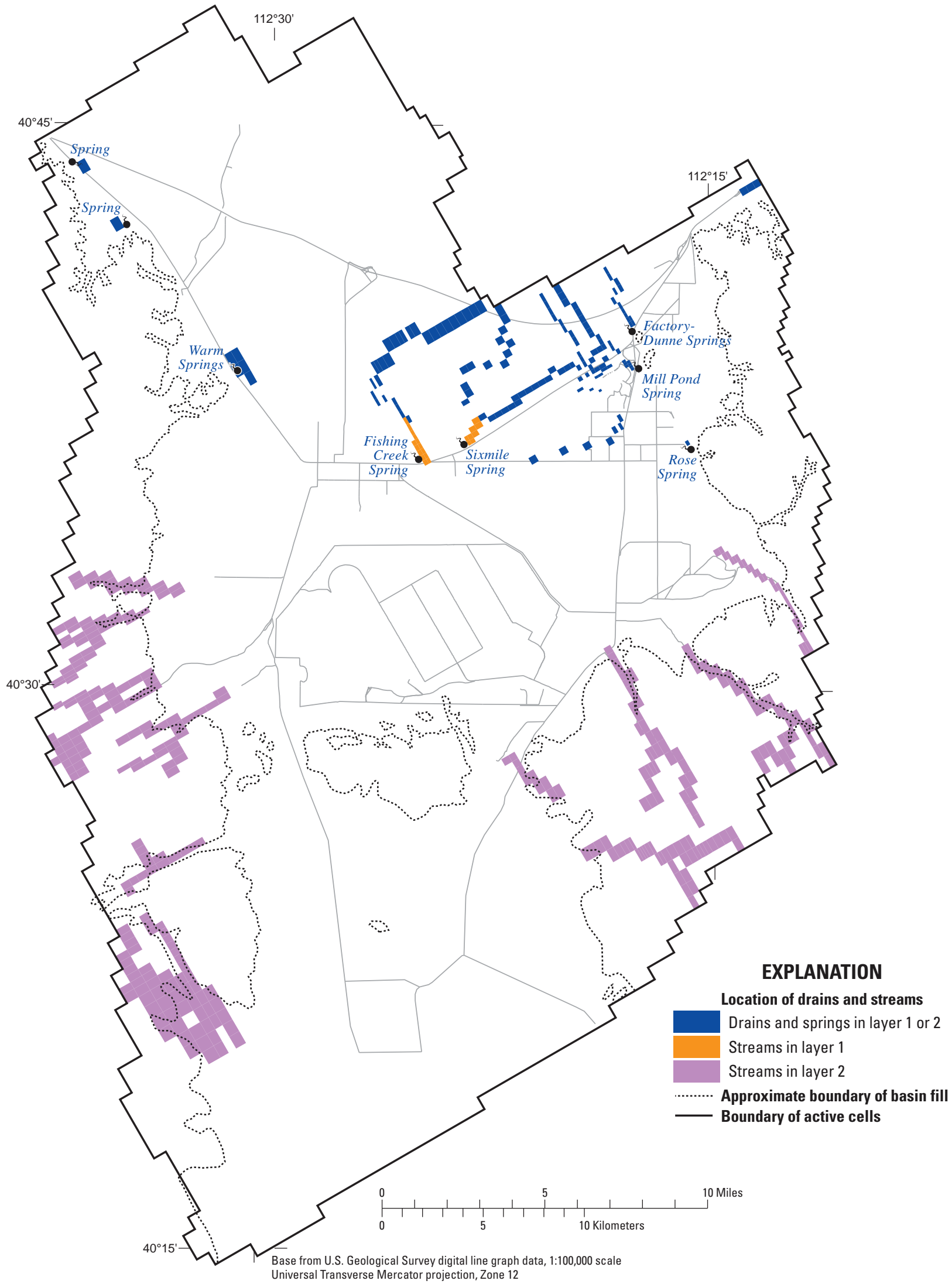

Figure 25. Location of drains and streams simulated in the ground-water flow model, Tooele Valley ground-water basin, Tooele County, Utah. 


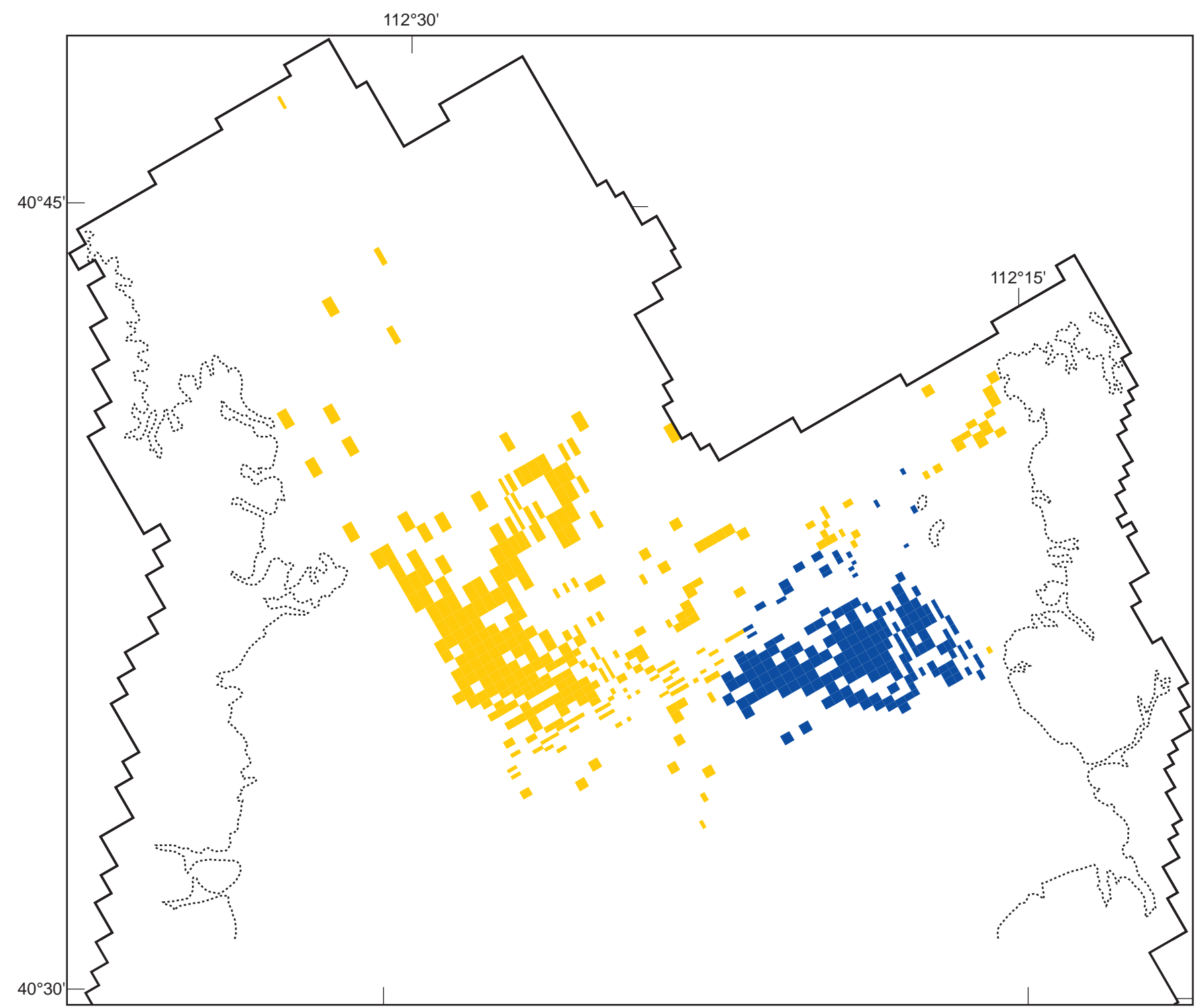

Base from U.S. Geological Survey digital line graph data, 1:100,000 scale Universal Transverse Mercator projection, Zone 12

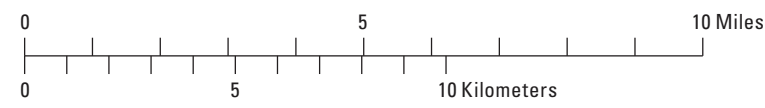

EXPLANATION

Location of simulated flowing wells in layer 2

Flowing wells in Erda and Stansbury area

Flowing wells in other areas

.......- Approximate boundary of basin fill

Boundary of active cells

Figure 26. Location of flowing wells simulated in the ground-water flow model, Tooele Valley ground-water basin, Tooele County, Utah.

general ground-water flow throughout Tooele and northern Rush Valleys and long-term water-level fluctuations. It should adequately represent basin-wide responses to changes in recharge and ground-water withdrawals, but has not been developed to simulate local effects of withdrawals or water budgets on a cell-by-cell basis. To determine the value and distribution of hydraulic conductivity, storage, drain conductance, and horizontal-flow barriers, model parameters were adjusted to cause simulated conditions to more closely match both steady-state and transient conditions.

\section{Parameter Adjustment and Sensitivity}

During model calibration, parameters were adjusted to achieve a model that reasonably represents the ground-water system by minimizing the sum of squared errors between simulated and measured water levels, subject to the constraints 
of the approximate known or estimated water-budget components. Horizontal and vertical hydraulic conductivity, specific yield and specific storage, and recharge from irrigation were adjusted both by modifying the distribution of the parameters with zone arrays and by adjusting the parameter values. Parameters defining recharge from precipitation, withdrawal from wells, and maximum evapotranspiration rate were not varied, but several parameters were assigned to recharge from precipitation (fig. 21) so that sensitivity to recharge in different areas could be determined. Drain conductance and horizontalflow barrier conductance were adjusted by modifying the parameter values. The location of horizontal-flow barriers also was adjusted.

The sensitivity of observations to parameters was used to aid model calibration. Composite scaled sensitivities can be used to evaluate whether available observations provide adequate information to estimate each parameter and can provide an overall view of the parameters to which the observations are most sensitive (Hill and others, 2000, p. 96). Simulated values at observation locations are more sensitive to extraction and injection at TEAD, recharge from precipitation on the north end of the Oquirrh Mountains, and specific yield in the TEAD area than to other model parameters (fig. 27). This is probably a result of concentration of observations near those areas. Other studies in Tooele Valley collected waterlevel data in Lake Point and near Erda, and those observations are probably sensitive to recharge on the north end of the Oquirrh Mountains. Many observations are related to drawdown associated with the extraction wells at TEAD. Simulated values at observation locations also are quite sensitive to withdrawal from wells, conductivity of horizontal-flow barriers in the TEAD area, and conductivity of consolidated rock in the Oquirrh Mountains and under Rush Valley (figs. 27 and 18).

Only one recharge or horizontal-conductivity parameter (krock3) has a composite scaled sensitivity of less than 1, which indicates that the observations provide enough data to justify the division of recharge and hydraulic-conductivity parameters into zones. Division of discharge into parameters with small sensitivities allowed better definition of type of discharge. Division of recharge from streams into three parameters was necessary to vary the recharge temporally in different ways in each area. Some model parameters were divided and refined even though the composite scaled sensitivities were not high. This achieved a better match between simulated water levels and observed water levels in some locations. Observations are relatively insensitive to some model parameters (fig. 27); consequently, it is difficult to assess how well these parameters are estimated in the simulation.

\section{Hydraulic Conductivity}

Because of the complicated geology and lacustrine and alluvial depositional environment, 22 hydraulic-conductivity parameters are used and assigned to different areas with zone arrays (figs. 17, 18, and 19). Both the distribution and the value of the parameters were adjusted during model calibra- tion to cause simulated water levels and spring discharge to match observations more closely.

In general, hydraulic conductivity of the basin fill is lower in the lower parts of the valley and near Great Salt Lake (fig. 17). Simulated values range from 0.5 to $400 \mathrm{ft} / \mathrm{d}$, which is a larger range than that reported by Lambert and Stolp (1999, fig. 17), but similar to the range reported by U.S. Army Corps of Engineers (2004, table 2). The largest value of hydraulic conductivity (parameter kc9, fig. 17) is near Mill Pond and Factory-Dunne Springs, and discharge to those springs is sensitive to this value (fig. 28).

Simulated values of hydraulic conductivity in consolidated rock range from 0.007 to $36 \mathrm{ft} / \mathrm{d}$ (fig. 18). Values reported by U.S. Army Corps of Engineers (2004, table 2) range from 60 to $100 \mathrm{ft} / \mathrm{d}$ and values reported by TriTechnics Corporation (1996, table 2) range from 0.001 to $0.25 \mathrm{ft} / \mathrm{d}$. Very few water-level measurements are available in consolidated rock except at the boundary with basin fill and in the TEAD area. Hydraulic conductivity of rock was adjusted mainly to simulate baseflow to streams, to reduce the areas of simulated water levels being above land surface in the mountains, and to match water levels and drawdown in the TEAD area. The largest value of conductivity (parameter krock9) occurs in TEAD and near Mill Pond and Factory-Dunne Springs, and discharge to those springs is sensitive to this value (fig. 28). Distribution of hydraulic conductivity of rock in the Stansbury Mountains was adjusted because discharge to streams such as the stream in Box Elder Canyon and Clover Creek is sensitive to these parameters (fig. 28). Most observations are insensitive to parameter krock3, which describes hydraulic conductivity of rock in the Pine Canyon area (fig. 18), but the simulated water levels near the mouth of Pine Canyon and in the Carr Fork shaft are sensitive to this parameter.

Simulated values of vertical hydraulic conductivity range from 0.001 to $1 \mathrm{ft} / \mathrm{d}$ (fig. 19). Lambert and Stolp (1999, fig. 21) report values ranging from 0.0005 to $10 \mathrm{ft} / \mathrm{d}$ in unconsolidated basin fill, U.S. Army Corps of Engineers (2004, table 2) report values ranging from 0.01 to $15 \mathrm{ft} / \mathrm{d}$ in unconsolidated basin fill and from $1 \times 10^{-5}$ to $20 \mathrm{ft} / \mathrm{d}$ in consolidated rock, and TriTechnics Corporation (1996, table 2) report values ranging from 0.001 to $1 \mathrm{ft} / \mathrm{d}$ in consolidated rock. It is probable that the value of $0.001 \mathrm{ft} / \mathrm{d}$ in basin fill represents areas where clay layers or lenses inhibit the vertical movement of ground water. It is not thought that sand and gravel layers have such extreme vertical anisotropy. Most model observations are not very sensitive to vertical hydraulic conductivity (fig. 27); conductivity was assigned different parameters to limit vertical-tohorizontal anisotropy to values from $2.5 \times 10^{-4}$ to about 7 in layers 2 to 5 , and from $1.0 \times 10^{-4}$ to 0.2 in layer 1 . In layers 2 to 5 , the smallest values of vertical-to-horizontal anisotropy are in basin-fill areas, indicating clay lenses and other layering increases vertical anisotropy, and the largest are in consolidated-rock areas. Several discharge observations are sensitive to vertical conductivity (fig. 28) and some of the zonation was required to match spring discharge observations. 


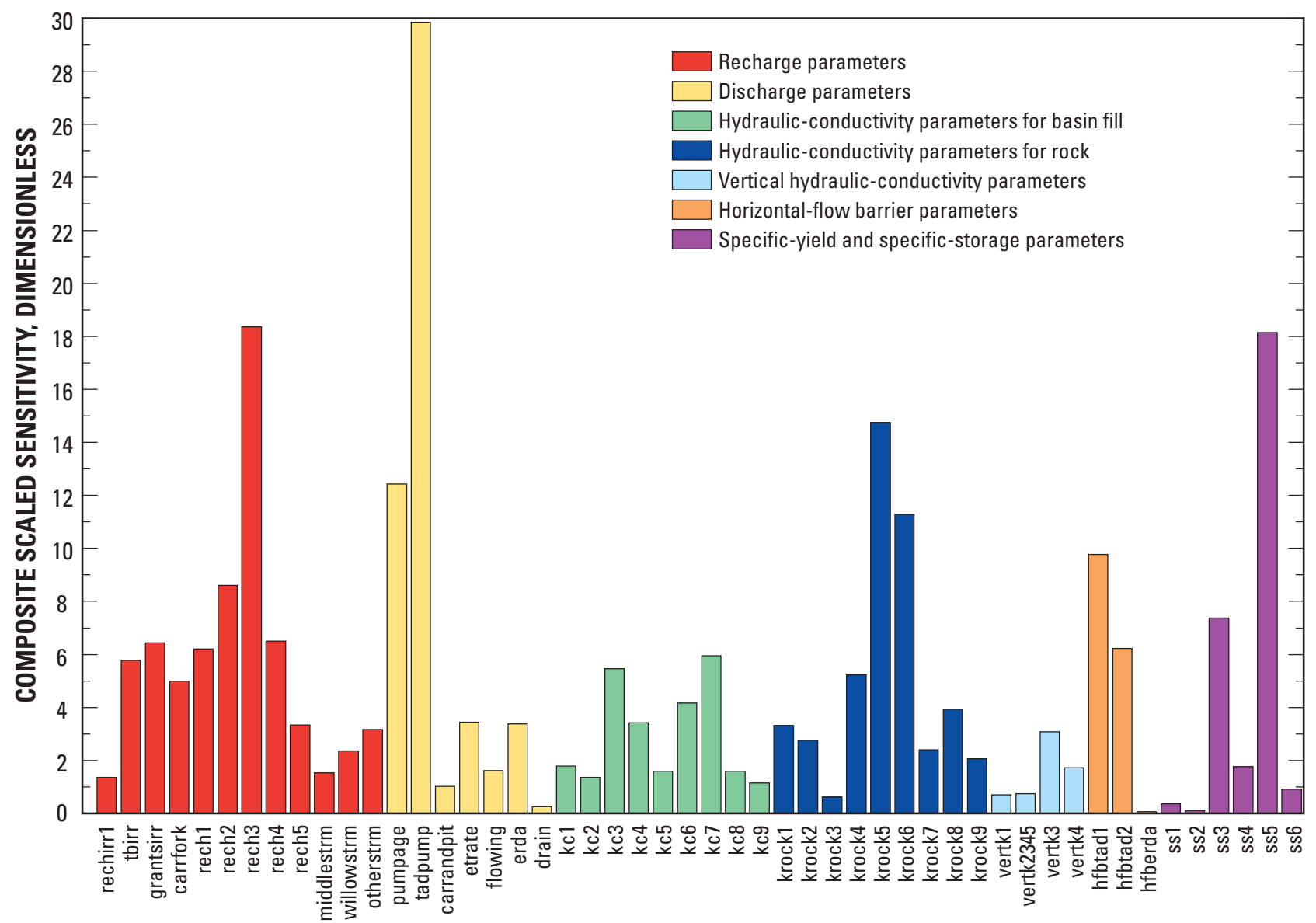

PARAMETER NAME

Figure 27. Composite scaled sensitivity of observations to model parameters in the ground-water flow model, Tooele Valley groundwater basin, Tooele County, Utah.

\section{Horizontal-Flow Barriers}

Simulated water levels at observations are sensitive to the location and conductance of horizontal-flow barriers in the TEAD area. These were adjusted as needed to match waterlevel and water-level change observations more closely. The value of hydraulic conductivity for horizontal-flow barriers in the simulated area ranges from $1 \times 10^{-5}$ to $0.0014 \mathrm{ft} / \mathrm{d}$. In the TEAD area, the value of conductivity for the horizontal-flow barriers was chosen to create a compromise between simulated high pre-pumping water levels and excessive simulated drawdown during pumping. The values of conductivity for horizontal-flow barriers in the TEAD area are 0.00022 and $0.0014 \mathrm{ft} / \mathrm{d}$. For the simulated barrier width of $1 \mathrm{ft}$, this conductivity corresponds to the range of leakance of 0.00025 to $0.001(\mathrm{ft} / \mathrm{d}) / \mathrm{ft}$ reported by U.S. Army Corps of Engineers (2007, table 2) for the same HFBs. The values of hydraulic conductivity in the model generally allow simulated levels in the area of extraction wells to be higher than observations before pumping, but to have more drawdown during pumping. Simulated March 2003 water levels approximately match March 2003 observations.

\section{Specific Yield and Specific Storage}

Two parameters are assigned to each of three zones of specific yield and specific storage (fig. 20). Both the distribution and value of the parameters were adjusted during model calibration. Generally, storage was reduced during model calibration, but it was increased in the area of TEAD to reduce simulated drawdown from withdrawal.

\section{Other Parameters}

The conductance of individual drains and streams also was adjusted during calibration. The conductance of different springs and drains were kept as consistent as possible while still allowing simulated discharge to approximate observed discharge. Measurements of drain, flowing well, and streambed conductance are not available. Generally, simulated water levels at observations are not very sensitive to the parameters middlestrm, willowstrm, otherstrm, drain, flowing, and erda (fig. 27), but the conductance was changed to better match discharge observations at springs and estimated baseflow of streams in the mountains. The simulated water levels in layer 1 also are sensitive to drain conductance; water levels were above land surface if drain conductance was too low. 

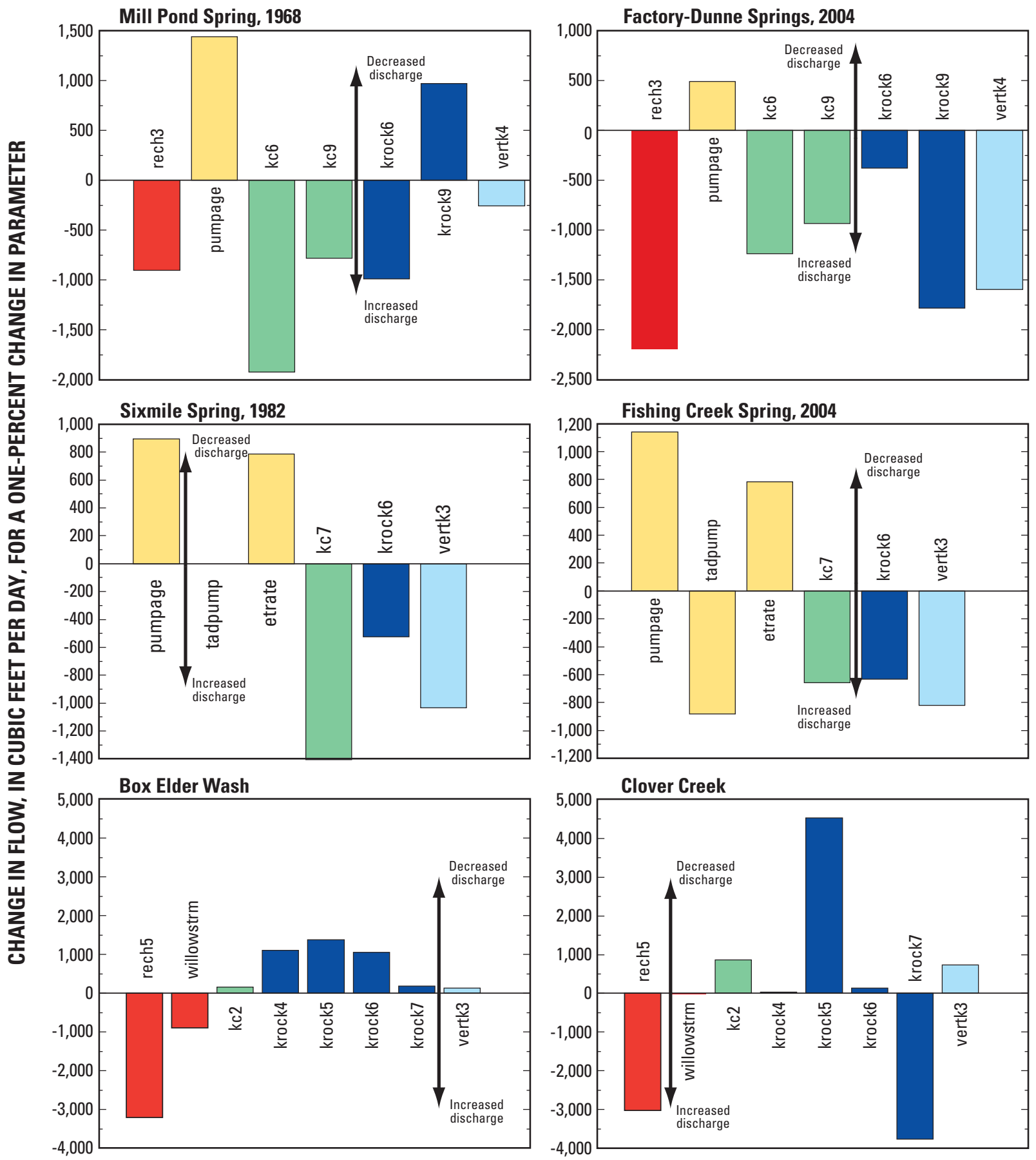

\section{EXPLANATION}

Recharge parameters

Discharge parameters

Hydraulic-conductivity parameters for basin fill

Hydraulic-conductivity parameters for rock

Vertical hydraulic-conductivity parameters

Figure 28. One-percent scaled sensitivity of stream and spring observations to selected model parameters simulated in the groundwater flow model, Tooele Valley ground-water basin, Tooele County, Utah. 


\section{Steady-State Calibration}

Ground-water levels measured in March 1969 and the conceptual ground-water budget for 1968 were compared to simulated values to determine if the model adequately simulates the ground-water system as it was in the late 1960s. MODFLOW-2000 calculates simulated values of water levels at the location of input observations, and calculates the difference between observation values and simulated values, weighted residuals, and other statistical measures of model fit. Fifty-five water levels measured by the USGS

(Appendix C, table 1) and one discharge measurement from Mill Pond Spring (Van King, Kennecott Land Company, written commun., 2005) are used as observations for the steadystate period.

Overall, the steady-state period of the ground-water flow model adequately simulates water levels observed in March 1969. Simulated levels are within $5 \mathrm{ft}$ of many observed water levels and exceed a difference of $10 \mathrm{ft}$ in only 10 of the 55 observed levels (fig. 29). The uncertainty in observed levels is about $5 \mathrm{ft}$ because most well altitudes are determined from topographic maps. The model error, therefore, is generally about the same as observed error. Even the maximum difference of $22 \mathrm{ft}$ is only about 2 percent of the gradient through the valley fill. High and low residual values are evenly spread throughout the area with water-level observations.

Ground-water flow indicated by contours of simulated water levels is similar to ground-water movement indicated by contours of measured water levels in March-April 1962 (Gates, 1965, fig. 6) and in March-April 1978 (Razem and Steiger, 1981, fig. 5). Similarities between simulated water levels and measured water levels indicate that the magnitude and distribution of recharge, discharge, and aquifer characteristics adequately represent the ground-water system.

The conceptual and simulated ground-water budgets are presented in table 9. Because almost all recharge is specified and was not adjusted during calibration, the simulated recharge matches the conceptual recharge within rounding error. Simulated individual budget components are similar to conceptual individual components.

A few areas of the model have simulated water levels above land surface. These are concentrated near Erda, in the Stansbury Mountains, and in northern Rush Valley. In Erda, it was difficult to match observed water levels and estimated discharge to flowing wells in deeper model layers without causing water levels in layer 1 to be above land surface. It is probable in the Erda area that complicated geology is contributing to model error. In the Stansbury Mountains, it was not possible to match estimated discharge to streams in North Willow, South Willow, and Box Elder Canyons without the simulated water levels in layer 2 being above land surface. Problems in this area could be caused by incorrect estimates of stream baseflow, by geologic complexities that are not simulated, or by inaccurate interpolation of land-surface altitude. The model is considered less well calibrated in Rush Valley because fewer water-level data are available. Also, the study did not include detailed analysis of evapotranspiration in Rush Valley and the maximum rate simulated could be incorrect.

Simulated water levels are below the altitude of Rose Springs and Big Springs. No discharge, therefore, occurs to those springs in the simulation. Measured water levels in wells near those springs are substantially below the altitude of the springs; it is possible that the springs discharge from locally perched ground water.

\section{Transient Calibration}

Transient calibration involved comparing simulated water-level and discharge fluctuations to measured water-level and discharge fluctuations from 1969 to 2004, simulated water levels at the end of stress period 35 to water levels measured in March and April, 2003, and ground-water budget components from stress period 36 to estimated budget components in 2003. Water-level data collected in February, March, or April from 1969 to 2004 were used as observations in the transient periods. At wells with more than one water-level measurement, the change in water level between measurements was used as an observation instead of the water level. This removed error associated with land-surface altitude and put more emphasis on the simulation matching long-term water-level fluctuations and on the sensitivity of water-level fluctuations to model parameters. In the transient simulation, water levels from 327 wells were used as observations for a total of 1,341 observations during 1969-2004. The USGS measured water levels in 222 of the wells (Appendix C, table 1); TEAD measured water levels in 105 of the wells (Appendix C, table 2 and U.S. Army Corps of Engineers, 2005).

This study included water-level measurements and discharge measurements; most of the data were collected in 2003. The comparisons of simulated water levels and budget to measured water levels and an estimated ground-water budget, therefore, were made for 2003. The simulated budget was compared to the conceptual budget to determine if the transient simulation adequately represented changes in the ground-water system through time.

\section{Water Levels}

The main emphasis of the transient calibration was to adjust the model to simulate measured water-level fluctuations more accurately. Twenty-seven long-term hydrographs throughout the valleys (fig. 30) were chosen to compare with simulated water levels. Except near Great Salt Lake, measured water levels fluctuate in response to annual and long-term changes in precipitation (fig. 31, hydrographs A-AA). Simulated water levels also fluctuate in response to changes in precipitation, but generally react faster than measured water levels. For example, simulated high water levels peak in 1985, but measured levels typically reach high levels in 1985 or 1986 and stay high for about 3 years. Both observed and simulated water-level fluctuations at individual wells probably are influenced by local ground-water withdrawals. Incorrect estimates 
Table 9. Conceptual ground-water budget for 1968 and ground-water budget simulated in the steady-state period of the ground-water flow model, Tooele Valley ground-water basin, Tooele County, Utah.

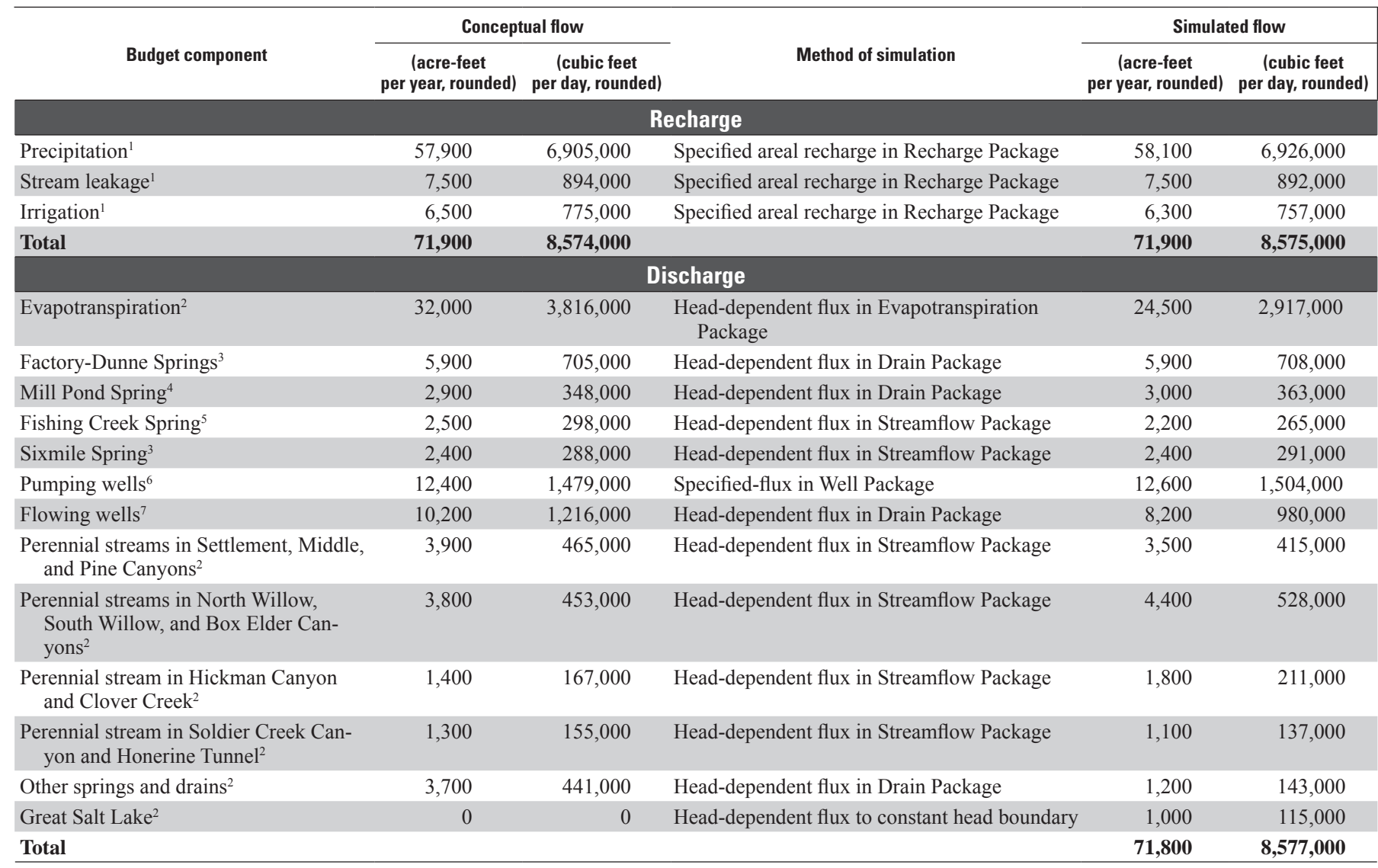

${ }^{1}$ The steady-state calibration period of 1964 to 1968 had lower precipitation than the 1971-2000 average. Therefore, the recharge from precipitation, stream leakage, and irrigation presented here is less than that presented in table 2 .

${ }^{2}$ The discharge from these budget components is assumed to be the same in 1964-1968 as from 1971-2000 and represents long-term average conditions.

${ }^{3}$ Flow rate for 1970 from Van King (Kennecott Land Company, written commun., 2005).

${ }^{4}$ Flow rate from Van King (Kennecott Land Company, written commun., 2005).

${ }^{5}$ Flow rate from Razem and Steiger (1981, p. 16) for 1977

${ }^{6}$ Burden and others (2007, fig. 12).

${ }^{7}$ Razem and Steiger (1981, p. 15) for 1977.

of annual withdrawals at individual wells may contribute to some of the differences between measured and simulated water levels.

In Lake Point and Stansbury Park, measured annual water-level fluctuations are less than $15 \mathrm{ft}$, probably because these areas have natural ground-water discharge that controls ground-water levels (fig. 31, hydrographs A and B). The model accurately represents the annual water-level fluctuations in the Stansbury Park area, but underestimates the changes in Lake Point.

Measured water levels and water-level fluctuations vary greatly in the small area of Erda. The water levels shown on hydrographs B, C, and E-H (fig. 31) were measured in wells that are within about $3 \mathrm{mi}$ of one another, but long-term average water levels vary from $4,380 \mathrm{ft}$ to $4,280 \mathrm{ft}$, and annual fluctuations range from about $10 \mathrm{ft}$ (fig. 31, hydrograph G) to about $35 \mathrm{ft}$ (fig. 31, hydrograph C). Simulated water-level fluctuations match the trends, but underestimate the annual fluctuations, especially in well (C-2-4)29adc-1 (fig. 31, hydrograph F). The complex geology in this area is probably contributing to the inability of the model to match observed fluctuations. In the area east and south of Erda, measured and simulated annual water-level fluctuations are about $35 \mathrm{ft}$ (fig. 31, hydrographs C and D), probably because the areas are closer to both mountain and irrigation recharge areas.

Measured annual water-level fluctuations in wells near Fishing Creek and Sixmile Creek, range from less than $5 \mathrm{ft}$ to about $35 \mathrm{ft}$ (fig. 31, hydrographs I-L). Simulated water levels match the trends, but underestimate the amount of fluctuation in wells near the springs that form Fishing Creek and Sixmile Creek. Near Grantsville City, measured water-level fluctuations caused by changing precipitation recharge are less than $20 \mathrm{ft}$, smaller than in many other areas (fig. 31, hydrographs M-P). During the early 2000s, it appears that something other than climate fluctuations caused measured water-level declines. Ground-water withdrawals in the Grantsville City area averaged about 1,400 acre-ft/yr from 1995 to 1999 and about 2,700 acre-ft/yr from 2000 to 2003 . The model simulates 


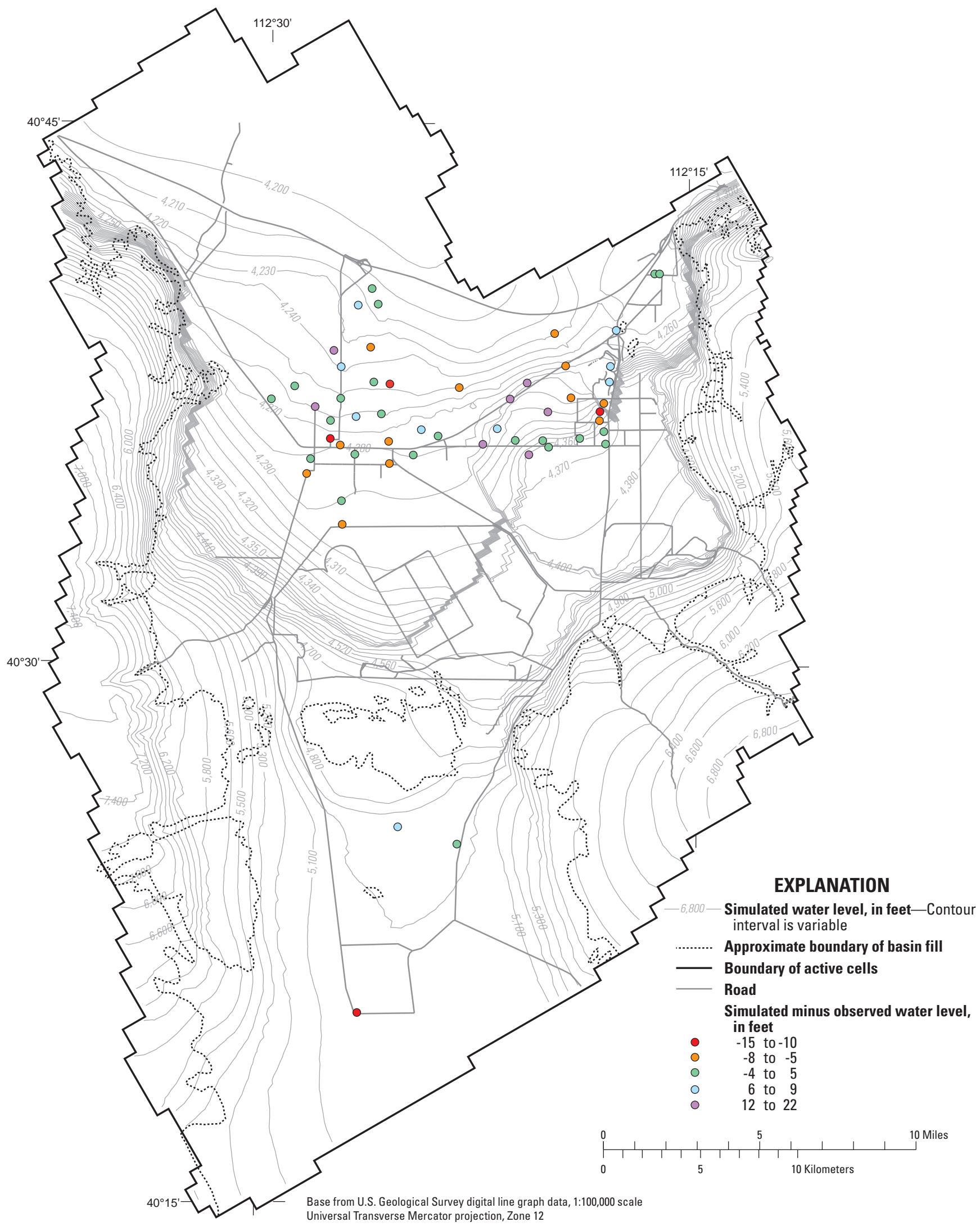

Figure 29. Water level simulated in the steady-state period of the ground-water flow model, and difference between simulated water level and water level measured in March 1969, Tooele Valley ground-water basin, Tooele County, Utah. 


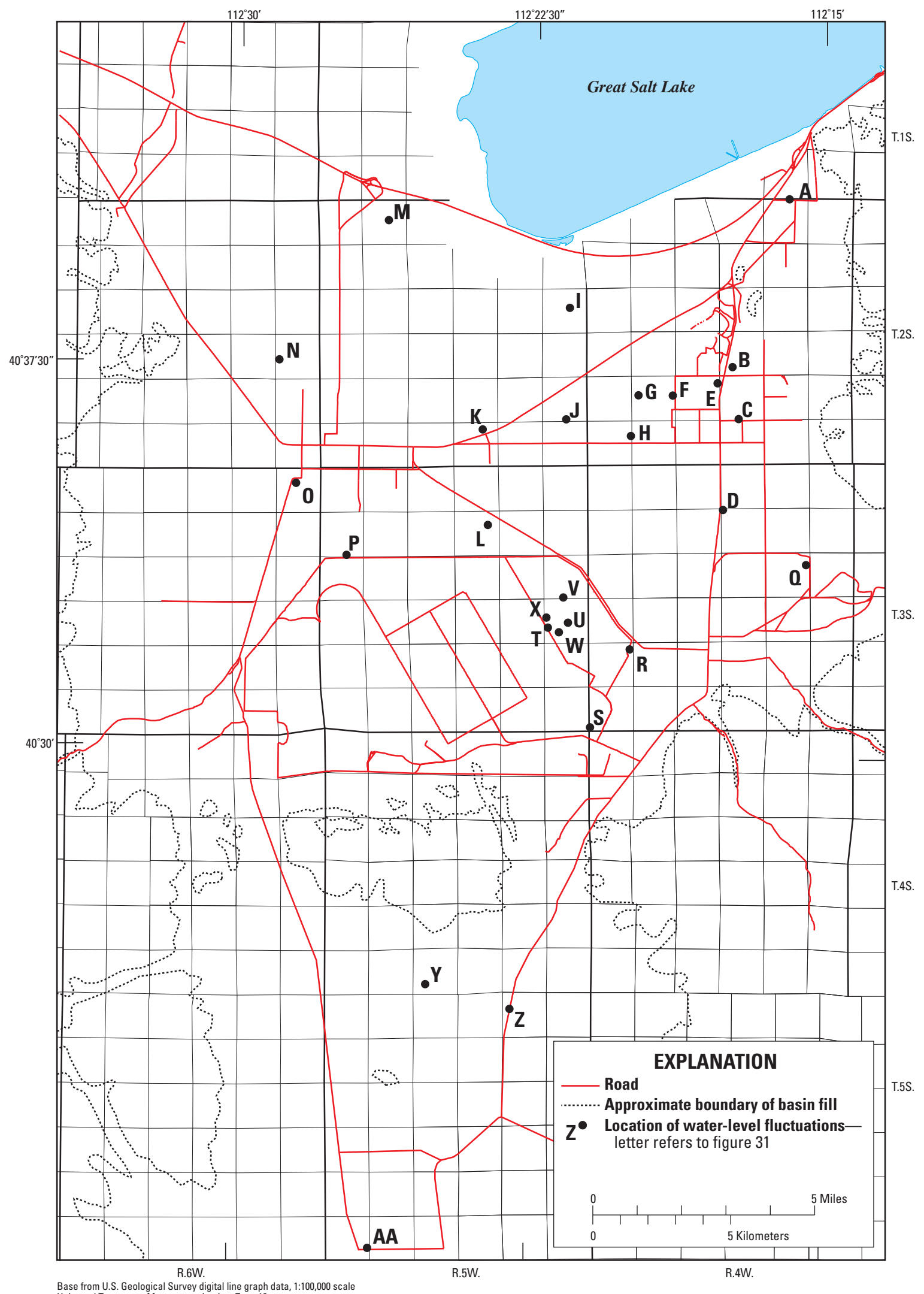

Base from U.S. Geological Survey digital line graph data, 1:100,000 scale
Universal Transverse Mercator projection, Zone 12

Figure 30. Location of selected measured and simulated water-level fluctuations, Tooele Valley ground-water basin, Tooele County, Utah. 


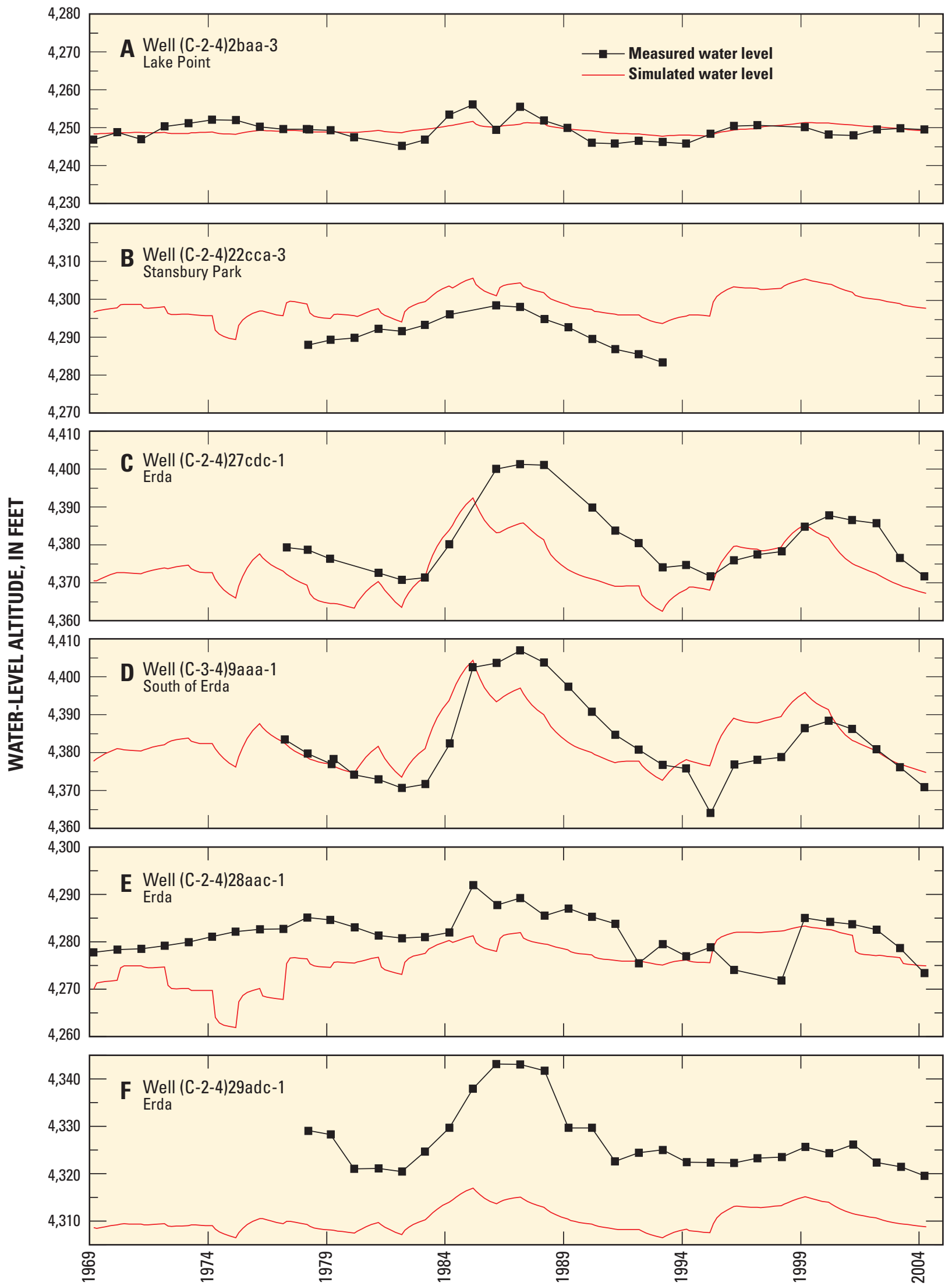

Figure 31. Water level simulated at the end of each stress period in the ground-water flow model and water level measured from March 1969 to April 2004 at 27 sites, Tooele Valley ground-water basin, Tooele County, Utah. 


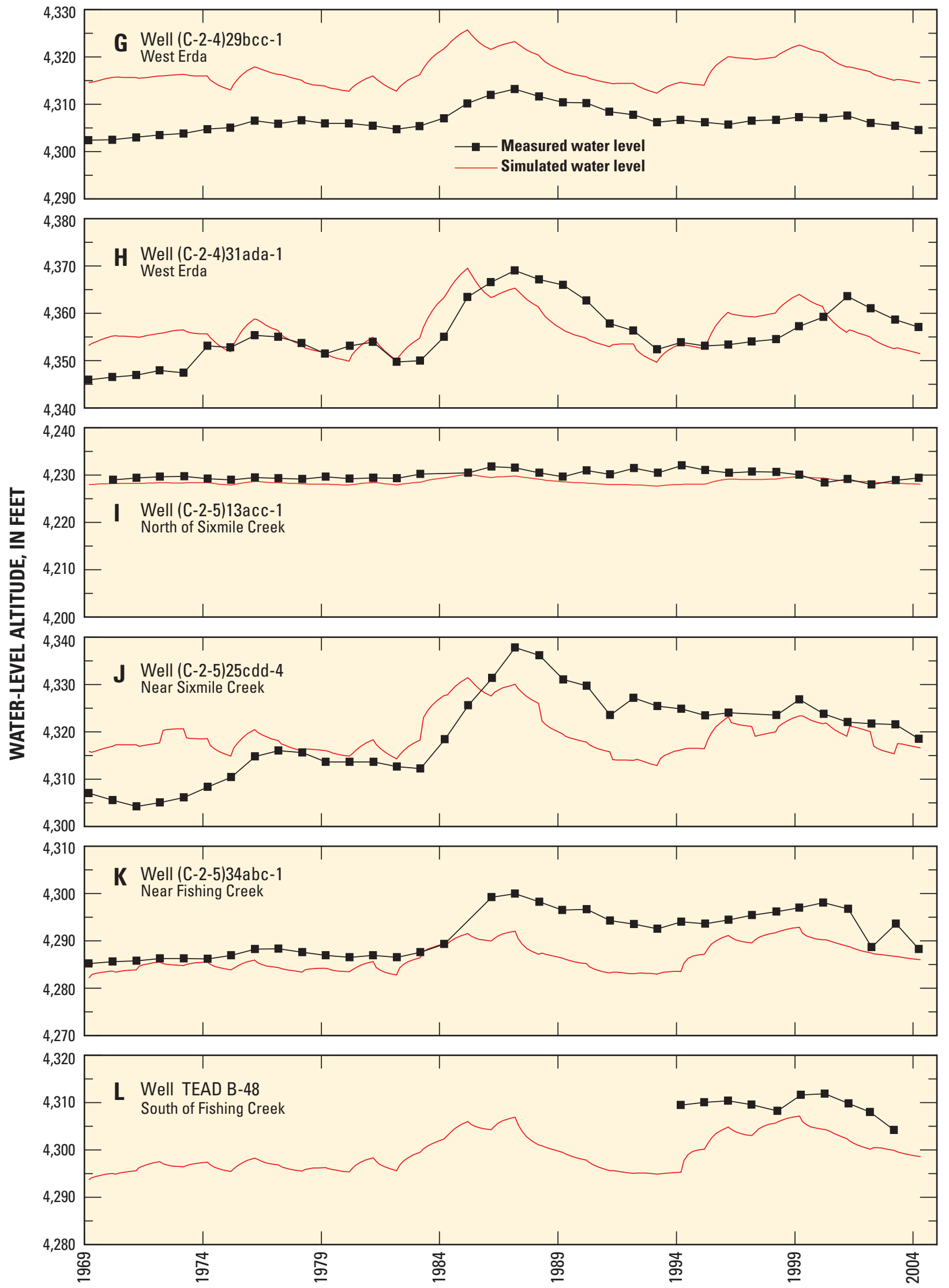

Figure 31. Water level simulated at the end of each stress period in the ground-water flow model and water level measured from March 1969 to April 2004 at 27 sites, Tooele Valley ground-water basin, Tooele County, Utah.-Continued 


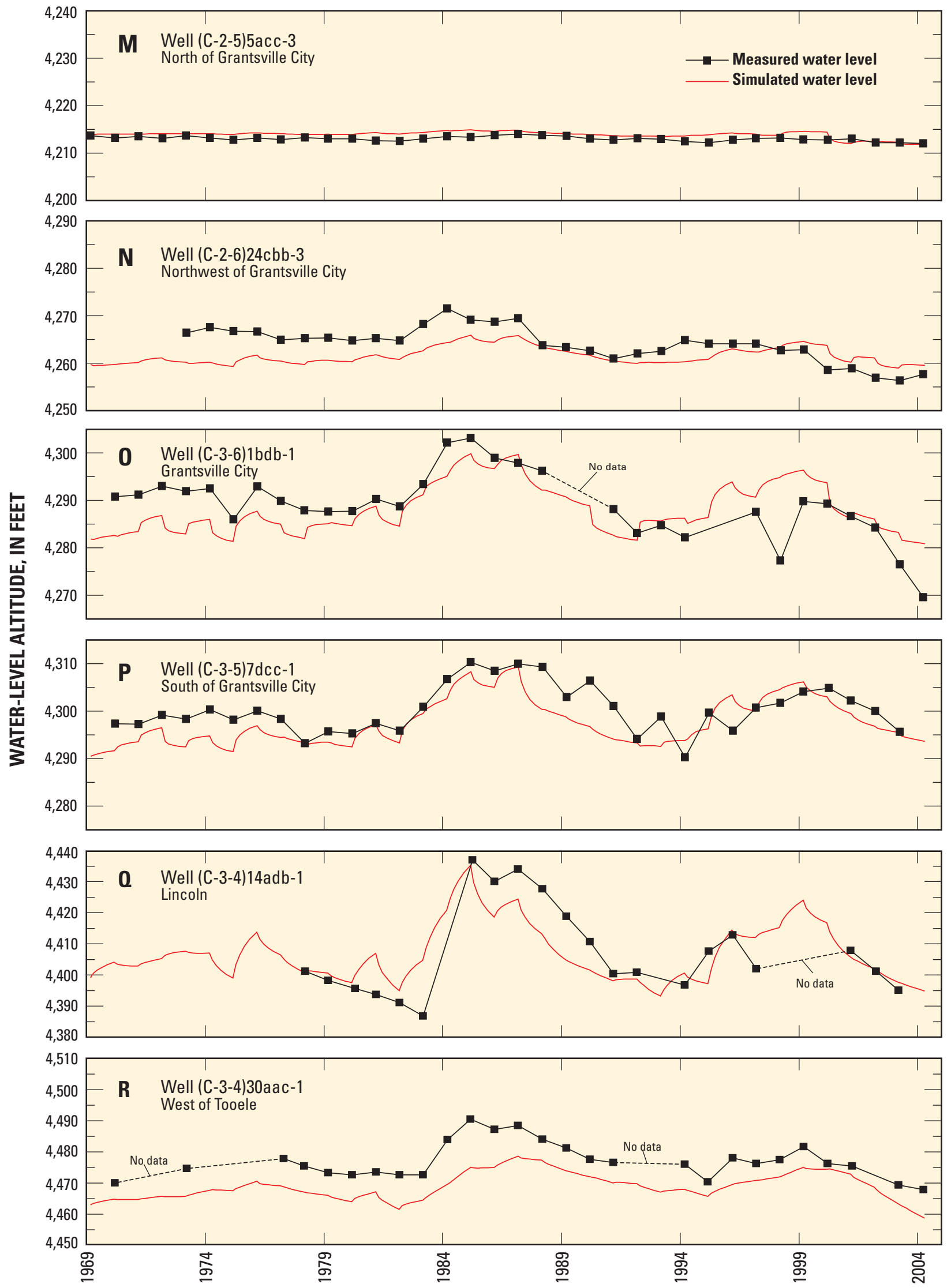

Figure 31. Water level simulated at the end of each stress period in the ground-water flow model and water level measured from March 1969 to April 2004 at 27 sites, Tooele Valley ground-water basin, Tooele County, Utah._Continued 

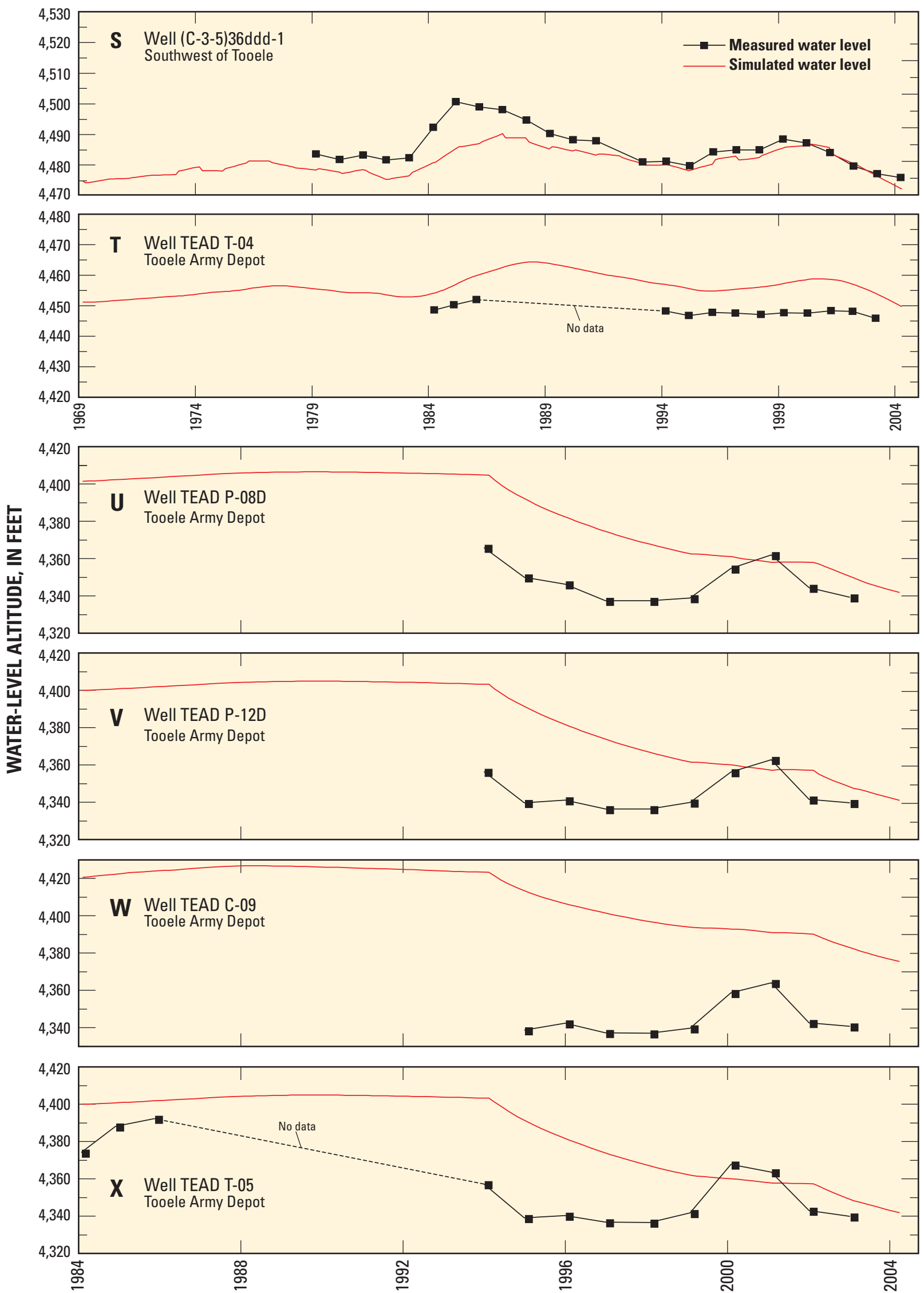

Figure 31. Water level simulated at the end of each stress period in the ground-water flow model and water level measured from March 1969 to April 2004 at 27 sites, Tooele Valley ground-water basin, Tooele County, Utah.-Continued 


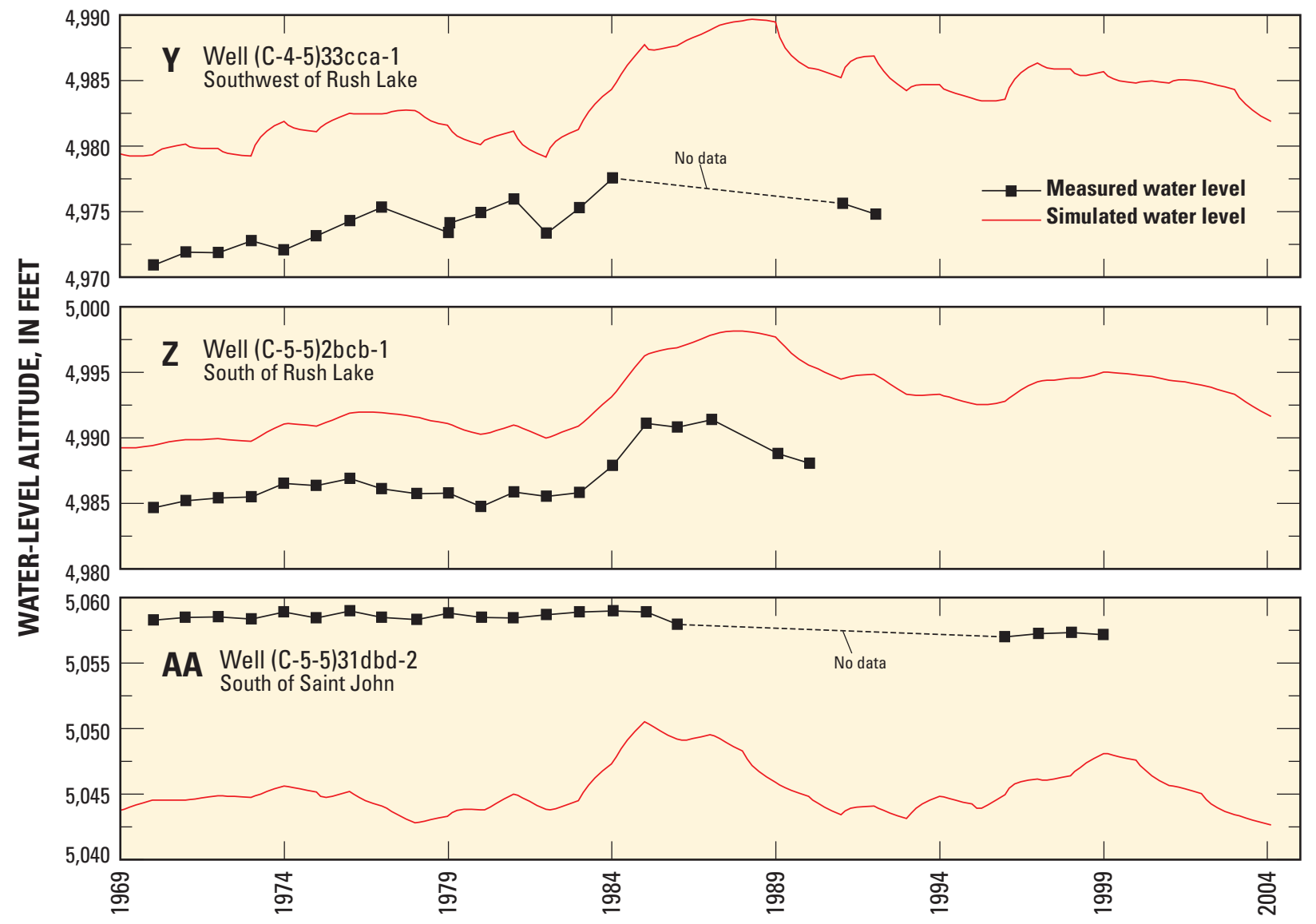

Figure 31. Water level simulated at the end of each stress period in the ground-water flow model and water level measured from March 1969 to April 2004 at 27 sites, Tooele Valley ground-water basin, Tooele County, Utah._Continued

decreased recharge from irrigation because of the reservoir and pressurized irrigation system after 1986, and increased withdrawals during 2000 through 2003. Simulated declines, however, are less than measured declines. Changing the storage coefficient had little effect on simulated water-level fluctuations in this area.

Measured water-level fluctuations near and east of Tooele City range from less than $10 \mathrm{ft}$ to more than $50 \mathrm{ft}$ (fig. 31, hydrographs Q-S) and follow precipitation trends (fig. 4). Simulated water levels and fluctuations are similar to measured levels and fluctuations in this area, indicating that annual fluctuations in recharge are simulated adequately. Recharge from irrigation in this area during 1983-86 is estimated to be about 240 percent of the 1971-2000 average. The model accurately simulates the trends in this area, indicating that major recharge fluctuations are adequately simulated.

The model adequately simulates flow through the TEAD area, but does not accurately simulate every water level and fluctuation (fig. 31, hydrographs T-X). Few wells in the area had water-level measurements before 1994, so it is difficult to determine how much drawdown occurred as withdrawals began in 1994 and how closely the model simulates that drawdown. The specific yield and specific storage were increased in the area of TEAD extraction wells to minimize the simulated drawdown to match measured water-level changes more closely.
Simulated water levels in the TEAD area are very sensitive to the amount of withdrawal (fig. 27). It is possible that the value of withdrawal simulated during 1994-98 (see "Discharge Boundaries" section of this report) does not accurately simulate the actual withdrawal. If simulated withdrawal were increased for this period, it is probable that water levels would decline more similarly to measured water levels. The data were not available, however, to justify the increased withdrawal. Simulated water levels in this area also are sensitive to both the location and conductance of horizontal-flow barriers (fig. 27), and a slight variation in the location of the barrier, as caused by discretization, limits the ability of the model to simulate all water levels accurately within the area of steep gradient (fig. 30). The complex geology in the area is simplified in this regional model. The U.S. Army Corps of Engineers (2007) has developed a more detailed flow and transport model of the TEAD area.

Limited long-term water-level data are available in northern Rush Valley. Available data indicate small annual fluctuations of less than $10 \mathrm{ft}$ (fig. 31, hydrographs Y-AA). Simulated water-level fluctuations also are small. Because water-level data are not available for long-term wells during 2000-04, it is not known whether water levels in Rush Valley declined similarly to water levels in Tooele Valley.

In addition to long-term hydrographs, the ability of the transient model to match March and April 2003 observed 
water levels also was evaluated (fig. 32). In general, the model adequately simulated the water levels in 2003. Simulated levels are within $10 \mathrm{ft}$ of most observed water levels and greater than $20 \mathrm{ft}$ different for only 16 of the 197 observed levels (fig. 32). The largest differences occur in the geologically complex areas of bedrock, including near the boundary between basin fill and consolidated rock and in TEAD. Hydraulic conductivity of consolidated rock was increased near pumping wells at the mouths of Settlement Canyon and Middle Canyon to better match observed effects of pumping on ground-water levels. Increasing the conductivity too much, however, caused discharge to streams in the canyons to be lower than estimated baseflow. It is possible that these areas also have higher specific yield and specific storage than surrounding consolidated rock because of fractures. Because long-term water-level fluctuations were not available, the storage parameters were not changed at the canyon mouths.

Positive and negative water-level residuals (simulated minus observed) generally are evenly distributed throughout the model, but in the areas near Grantsville City and TEAD simulated levels commonly are greater than observed levels. In general, the model accurately simulates water levels and water-level fluctuations and is considered to be an adequate tool to help determine the valley-wide effects on water levels of additional ground-water withdrawal and changes in water use.

\section{Discharge and Water-Budget Components}

Simulated discharge to streams and springs was compared to measured streamflow and spring discharge (fig. 33). Limited stream discharge data on the east side of the valley precluded comparison of simulated discharge to flow in Middle Canyon, Settlement Canyon, and Soldier Creek. On the west side of the valley, simulated discharge to streams (baseflow) generally follows the same trend as measured streamflow. Years of high measured streamflow correspond to years of higher recharge, higher ground-water levels, and more ground-water discharge to streams. During years with belownormal streamflow, simulated discharge to streams (baseflow) exceeds measured streamflow. This could indicate that during years of below-normal precipitation, simulated recharge in those areas is too high, which causes simulated water levels and discharge to streams to be too high. It is also possible that simulated storage is too high, which causes water levels to remain high even during years of below-average recharge. Simulated storage parameters were reduced in the Stansbury Mountains in an attempt to minimize baseflow during years with below-normal recharge. In general, simulated discharge to streams is about 30 to 60 percent of the total estimated streamflow; this is similar to the proportion of the total estimated streamflow that is considered baseflow (table 1).

Simulated discharge to springs is similar to measured discharge during the early stress periods, but deviates substantially during some stress periods (fig. 33). Simulated discharge to Factory-Dunne Springs and Fishing Creek is similar to measurements at the end of the simulated period. Because springs are simulated as head-dependent boundaries, the simulated variation in discharge to springs is similar to water-level fluctuations. Measured discharge to springs, however, does not follow the same pattern. A possible cause for the difference is that measured spring discharge includes a component of surface water or shallow irrigation return flow. These processes are not simulated in the ground-water flow model. Another possibility is that spring discharge measurements made in the late 1960s and used to calibrate the model were not made at the same locations as later measurements. The four large springs become channelized flow. Depending on where the discharge is measured, additional discharge could occur along the stream below the measurement site, flowing wells above the site could be included as spring discharge, and diversions could occur upstream of the measurement site.

The conceptual ground-water budget for 2003 is compared with the ground-water budget simulated for stress period 36 in the transient ground-water flow model in table 10. Simulated recharge is about 99 percent of conceptual recharge; the reason for this small difference is because recharge multipliers in the model are assigned an average for a few years, not each individual year. Simulated discharge to major springs in stress period 36 is about 2,500 acre-ft/yr less than estimated in 2003. About 50 percent of the difference between simulated and estimated discharge occurs at Mill Pond Springs.

With the exception of Mill Pond Springs, estimated discharge to major springs in 2003 and 2004 was about 120 percent of estimated discharge in 1968; simulated discharge in stress period 36 is about 111 percent of simulated steadystate discharge. The reasons for the measured and simulated increase in spring discharge are complex. Precipitation from 1999 to 2003 was less than precipitation from 1964 to 1968, but both measured and simulated discharge to springs appear to have been affected by the longer-term effects of higherthan average precipitation from 1980 to 1987 and from 1993 to 1998 , indicating a lag in the response of spring discharge to climate variability. Withdrawal from large irrigation wells close to most major springs has also decreased from 1968 to 2003, which could also allow water levels and discharge to springs to increase. The similar amount of increase in both simulated and measured discharge indicates that simulated recharge, withdrawal, and storage are approximately correct. The discharge from Mill Pond Springs measured in 2003 is 162 percent of reported discharge in 1968; the reason for the large increase is not known, but could be related to differences in measurement location, diversions, and a combination of other factors described above.

Simulated discharge to streams in stress period 36 is about 1,300 acre-ft/yr less than the estimated long-term average baseflow. It is likely that actual baseflow to streams in 2003 is less that the long-term average because there were several years of less-than-average precipitation before 2003 . Not enough streamflow data are available to determine actual baseflow in 2003.

Stress period 36 in the transient simulation includes a decrease in ground-water storage of 32,300 acre-ft. A 


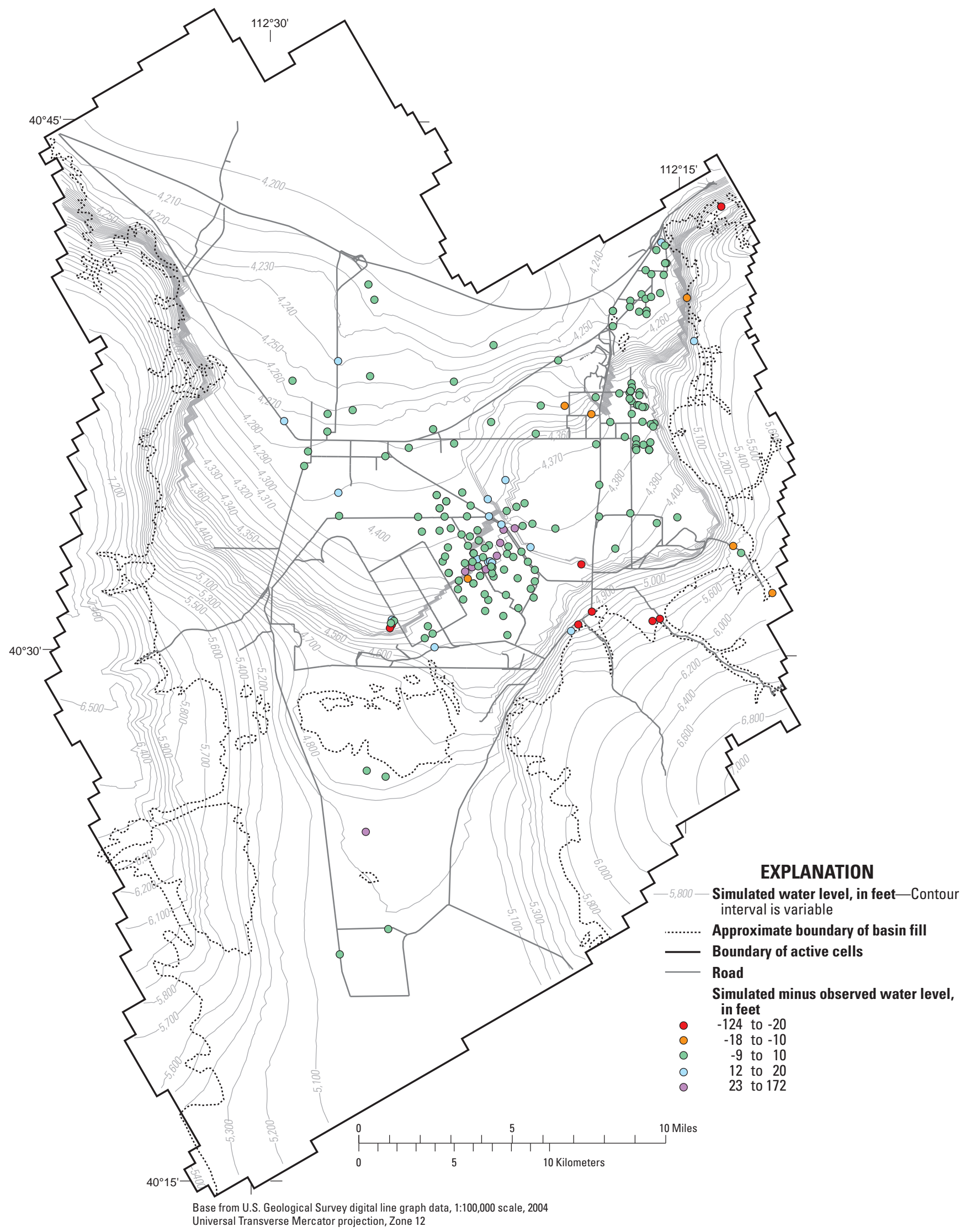

Figure 32. Water level simulated at the end of stress period 35 of the ground-water flow model and difference between simulated water level and water level measured in March-April 2003, Tooele Valley ground-water basin, Tooele County, Utah. 

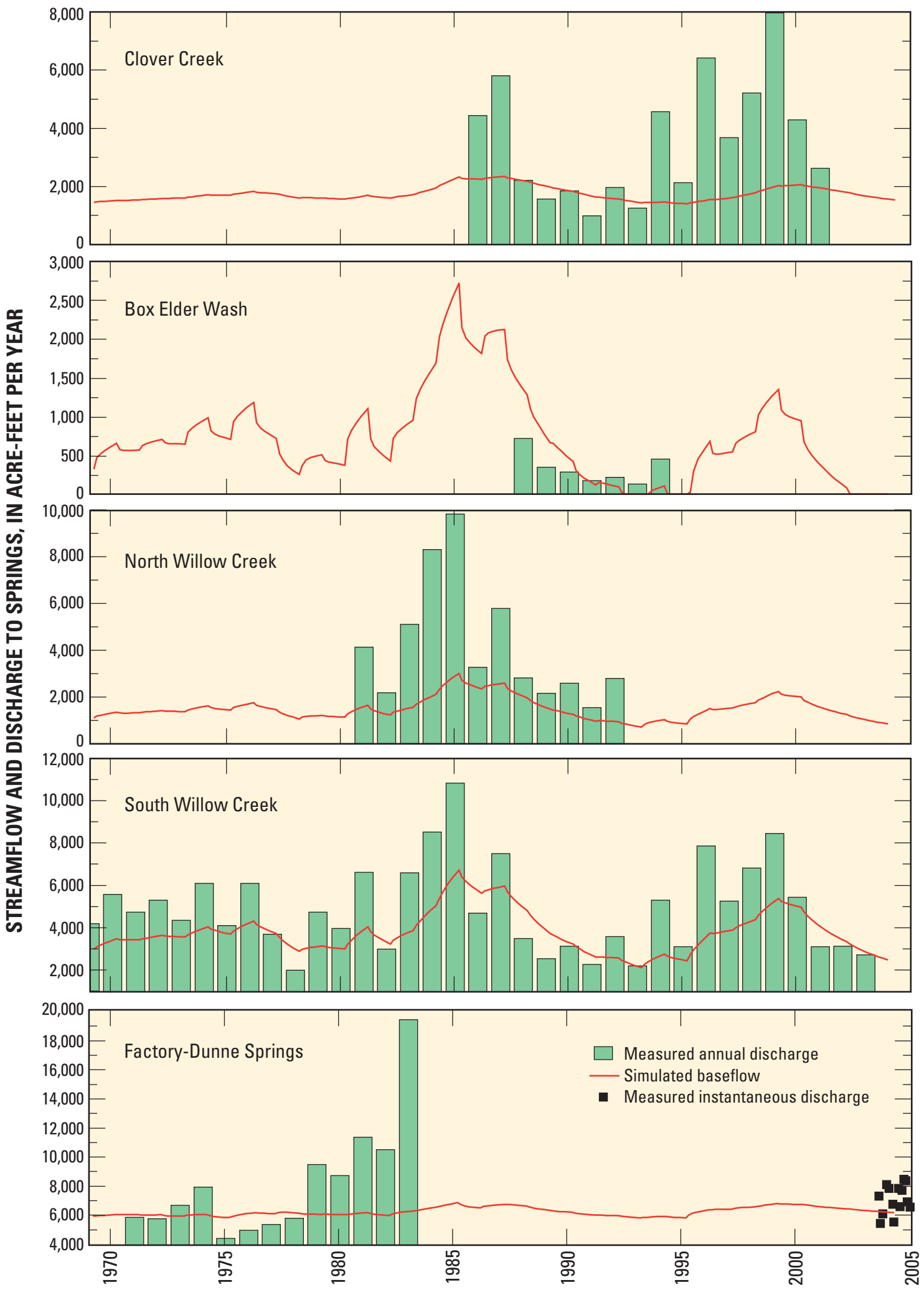

Figure 33. Discharge simulated at the end of each stress period in the ground-water flow model and streamflow and spring discharge measured from 1968 to 2004, Tooele Valley ground-water basin, Tooele County, Utah. 


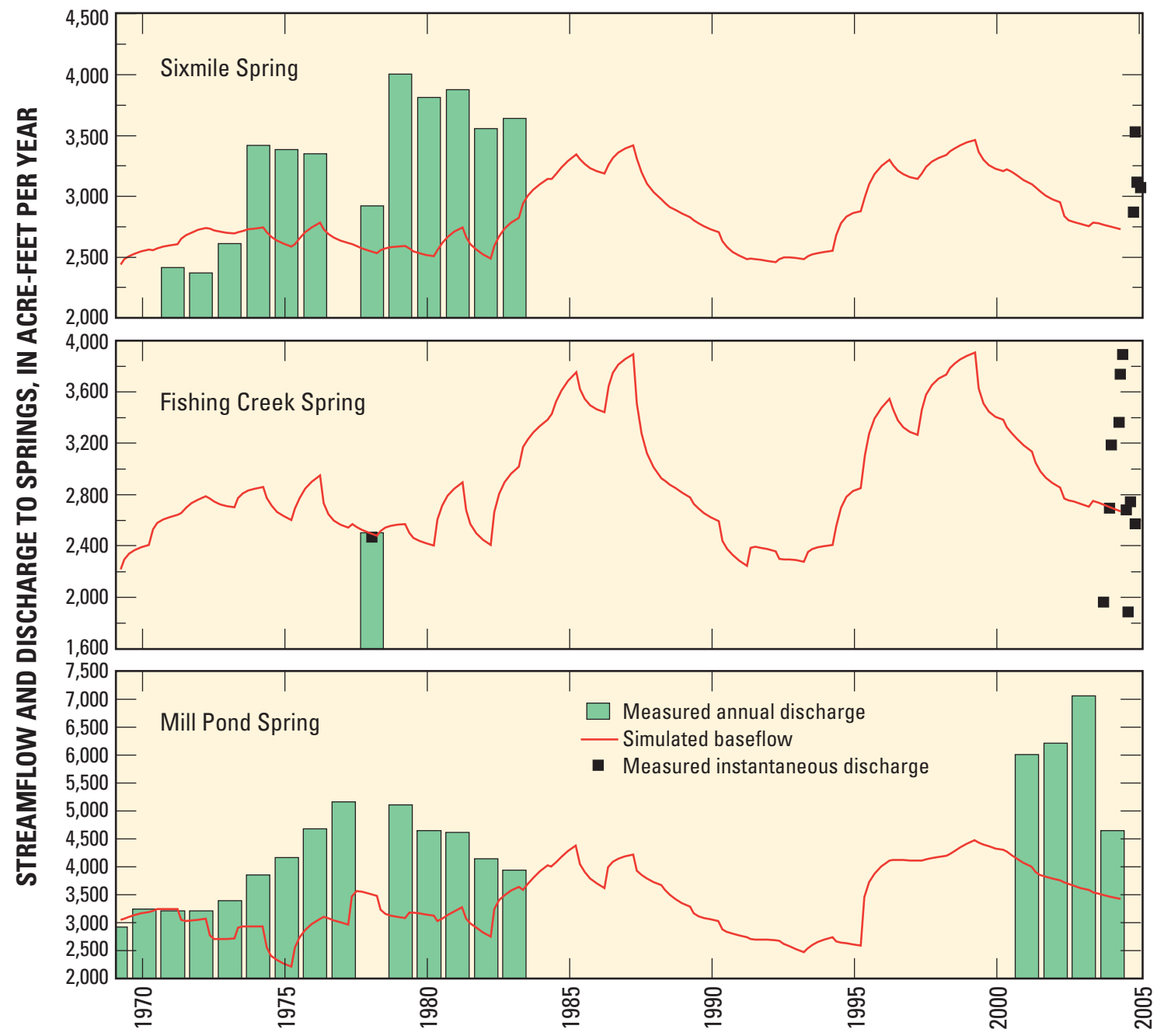

Figure 33. Discharge simulated at the end of each stress period in the ground-water flow model and streamflow and spring discharge measured from 1968 to 2004, Tooele Valley ground-water basin, Tooele County, Utah.-Continued

conceptual amount for decrease in storage was not calculated, but most wells with water levels in 2004 have lower levels than in 2003 (fig. 31), indicating a decrease in ground-water storage.

\section{Sensitivity Analysis and Suggested Locations for Data Collection}

MODFLOW-2000 can be used to create one-percent scaled sensitivity maps of water levels in every model cell (Hill and others, 2000, p. 71). These show how much waterlevel change would occur for a one-percent increase in the parameter value and can be used to indicate areas where water levels change the most for a change in model parameter. An analysis of these maps indicated that several observation wells used in this model are located in areas sensitive to certain parameters (table 11). For some parameters with high onepercent scaled sensitivities, however, water-level observations are not available in areas most sensitive to the parameter. Areas with highest sensitivity are in the mountains or near the boundary of consolidated rock and unconsolidated basin fill and few wells exist in those areas. The locations of available water-level observations from March 1969 to 2004 and other locations with the highest one-percent scaled sensitivity in stress period 36 in layer 2 to selected model parameters are shown in figure 34 . Water-level data collected at sites where data were not available for the calibration period may help refine the model and the conceptual understanding of the ground-water system. Water-level data collected in the future at sites used during this study may indicate changes occurring in the ground-water system. Long-term water-level fluctuations at new sites would be needed to refine estimates of specific yield and specific storage.

Model parameters tadpump, ss5, hfbtad1, and hfbtad2 have high composite scaled sensitivity (fig. 27), but not high one-percent scaled sensitivity. The water levels in TEAD are sensitive to these parameters; the number of water levels available in the area contribute to the high composite scaled sensitivity. One-percent scaled sensitivities indicate that a 1-percent increase in parameter tadpump would decrease water levels in 
Table 10. Conceptual ground-water budget for 2003 and ground-water budget simulated in stress period 36 of the transient groundwater flow model, Tooele Valley ground-water basin, Tooele County, Utah.

[TEAD, Tooele Army Depot]

\begin{tabular}{|c|c|c|c|c|c|}
\hline \multirow[t]{2}{*}{ Budget component } & \multicolumn{2}{|c|}{ Conceptual flow } & \multirow[t]{2}{*}{ Method of simulation } & \multicolumn{2}{|c|}{ Simulated flow } \\
\hline & $\begin{array}{l}\text { (acre-feet } \\
\text { per year, } \\
\text { rounded) }\end{array}$ & $\begin{array}{l}\text { (cubic feet } \\
\text { per day, } \\
\text { rounded) }\end{array}$ & & $\begin{array}{l}\text { (acre-feet } \\
\text { per year, } \\
\text { rounded) }\end{array}$ & $\begin{array}{l}\text { (cubic feet } \\
\text { per day, } \\
\text { rounded) }\end{array}$ \\
\hline \multicolumn{6}{|c|}{ Recharge } \\
\hline Precipitation & 37,200 & $4,431,000$ & Specified areal recharge in Recharge Package & 37,300 & $4,370,000$ \\
\hline Stream leakage & 3,100 & 370,000 & Specified areal recharge in Recharge Package & 3,100 & 370,000 \\
\hline Irrigation & 3,800 & 453,000 & Specified areal recharge in Recharge Package & 3,600 & 436,000 \\
\hline Total & 53,100 & $6,333,000$ & & 53,000 & $6,255,000$ \\
\hline \multicolumn{6}{|c|}{ Discharge } \\
\hline Evapotranspiration & 32,000 & $3,816,000$ & $\begin{array}{l}\text { Head-dependent flux in Evapotranspiration } \\
\text { Package }\end{array}$ & 25,000 & $2,980,000$ \\
\hline Factory-Dunne Springs ${ }^{1}$ & 7,000 & 838,000 & Head-dependent flux in Drain Package & 6,200 & 742,000 \\
\hline Mill Pond Spring ${ }^{1}$ & 4,700 & 555,000 & Head-dependent flux in Drain Package & 3,500 & 415,000 \\
\hline $\begin{array}{l}\text { Perennial streams in Settlement, Middle, and Pine } \\
\text { Canyons }{ }^{2}\end{array}$ & 3,900 & 465,000 & Head-dependent flux in Streamflow Package & 2,500 & 295,000 \\
\hline $\begin{array}{l}\text { Perennial streams in North Willow, South Willow, } \\
\text { and Box Elder Canyons }{ }^{2}\end{array}$ & 3,800 & 453,000 & Head-dependent flux in Streamflow Package & 3,400 & 405,000 \\
\hline $\begin{array}{l}\text { Perennial stream in Hickman Canyon and Clover } \\
\text { Creek }^{2}\end{array}$ & 1,400 & 167,000 & Head-dependent flux in Streamflow Package & 1,800 & 214,000 \\
\hline $\begin{array}{l}\text { Perennial stream in Soldier Creek Canyon and } \\
\text { Honerine Tunnel }{ }^{2}\end{array}$ & 1,300 & 155,000 & Head-dependent flux in Streamflow Package & 1,400 & 161,000 \\
\hline Small springs and drains & 3,700 & 441,000 & Head-dependent flux in Drain Package & 1,200 & 149,000 \\
\hline Great Salt Lake & 0 & 0 & Head-dependent flux to constant head boundary & 1,000 & 118,000 \\
\hline Shaft and mine dewatering & 1,000 & 119,000 & Negative specified-flux in Recharge Package & 700 & 78,000 \\
\hline
\end{tabular}

${ }^{1}$ From USGS measurements, Appendix C, table 3.

${ }^{2}$ Baseflow estimates represent long-term averages and do not change in the conceptual budget.

the extraction area by about $0.35 \mathrm{ft}$ and increase water levels in the injection area by about $0.15 \mathrm{ft}$. A 1-percent increase in parameter ss 5 would increase water levels about $0.2 \mathrm{ft}$ in the extraction area and less than $0.03 \mathrm{ft}$ elsewhere. More area is sensitive to parameters hfbtad1 and hfbtad2, and a 1-percent increase in either of those parameters decreases water levels by up to $0.45 \mathrm{ft}$ on the south side of the barriers (fig. 35).

\section{Model Projections}

The ground-water flow model was used to estimate possible effects on water levels and water quality caused by lessthan-normal precipitation and streamflow and by increased withdrawal from wells. The projections assume the same distribution of ground-water withdrawal as for 2003 in stress period 36 of the transient simulation. The effects of locating wells in new areas are not projected, but new wells are located in cells near existing wells to prevent numerical instability caused by increased withdrawal concentrated at one cell. The projections use the distribution of irrigated lands and municipal areas simulated in the transient historical model.

The projections simulate the same conditions for 362 -yr stress periods to allow the simulated ground-water system to reach a new steady state with the imposed recharge and withdrawals. At steady state, little change in storage is occurring and total discharge approximately equals recharge. Because the projection simulations are near steady state after 36 years, the results at the end of stress period 18 are presented in this report. The simulated water-level change is the difference from the end of the transient historical simulation to the end of the projection simulation. The beginning water level is the water level simulated at the end of the transient historical simulation, not water levels measured in March 2004.

Model projections should not be used to predict actual water levels and water quality at some future date, but can give general ideas about water-level and water-quality changes likely to occur throughout the valley. The more the projected 
Table 11. Observations with the highest one-percent scaled sensitivity in stress period 36 in layer 2 to selected model parameters, Tooele Valley ground-water basin, Tooele County, Utah.

[Named wells had water levels sometime from 1969 to 2004 and may or may not be completed in layer 2; observations starting with "Obs" were not available during the calibration period; parameters with absolute one-percent scaled sensitivity less than 1.5 are not listed]

\begin{tabular}{|c|c|c|}
\hline $\begin{array}{c}\text { Model parameter } \\
\text { (from Appendix C, } \\
\text { table C6) }\end{array}$ & $\begin{array}{l}\text { Observations most sensitive to parameter } \\
\text { in model layer } 2 \\
\text { (from fig. 34) }\end{array}$ & $\begin{array}{l}\text { Approximate change in } \\
\text { simulated water level, } \\
\text { in feet, for a 1-percent } \\
\text { increase in parameter }\end{array}$ \\
\hline \multirow[t]{2}{*}{ rech5 } & Obs1 & 25.29 \\
\hline & $(C-3-6) 32 d b c-1,(C-3-6) 32 d b d-1$ & 0.97 \\
\hline \multirow[t]{2}{*}{ krock2 } & Obs1 & -16.39 \\
\hline & $(\mathrm{C}-2-3) 18 \mathrm{bcc}-1$ & -0.97 \\
\hline \multirow[t]{2}{*}{ rech3 } & Obs2 & 15.42 \\
\hline & $(\mathrm{C}-2-3) 18 \mathrm{bcc}-1$ & 6.50 \\
\hline \multirow[t]{3}{*}{ rech4 } & Obs3 & 12.56 \\
\hline & $(\mathrm{C}-3-4) 25 \mathrm{aad}-1$ & 1.86 \\
\hline & $(\mathrm{C}-3-3) 20 \mathrm{acb}-1,(\mathrm{C}-3-3) 20 \mathrm{bab}-1$ & 1.6 \\
\hline \multirow[t]{2}{*}{ krock5 } & Obs4 & -10.71 \\
\hline & $(\mathrm{C}-4-6) 1 \mathrm{dbb}-1$ & 0.84 \\
\hline \multirow[t]{4}{*}{ krock1 } & Obs2 & -9.04 \\
\hline & Obs1 & -3.00 \\
\hline & $(C-3-6) 32 d b c-1,(C-3-6) 32 d b d-1$ & 1.15 \\
\hline & $(\mathrm{C}-2-3) 18 \mathrm{bcc}-1$ & -0.82 \\
\hline \multirow[t]{2}{*}{ rech2 } & Obs4 & 6.54 \\
\hline & $(\mathrm{C}-3-3) 20 \mathrm{acb}-1,(\mathrm{C}-3-3) 20 \mathrm{bab}-1$ & 3.5 \\
\hline \multirow[t]{5}{*}{ krock6 } & Obs5 & -5.94 \\
\hline & Obs6, Obs3 & -4.3 \\
\hline & (C-4-4)18bbb-1 & 2.11 \\
\hline & $(\mathrm{C}-3-4) 25 \mathrm{aad}-1$ & -1.63 \\
\hline & $(\mathrm{C}-3-3) 20 \mathrm{acb}-1,(\mathrm{C}-3-3) 20 \mathrm{bab}-1$ & -1.05 \\
\hline \multirow[t]{2}{*}{ krock4 } & Obs7 & -5.78 \\
\hline & $(\mathrm{C}-3-6) 32 \mathrm{dbc}-1,(\mathrm{C}-3-6) 32 \mathrm{dbd}-1$ & -3.7 \\
\hline \multirow[t]{4}{*}{ krock7 } & Obs8 & -4.22 \\
\hline & Obs2 & -2.47 \\
\hline & Obs12 & -1.79 \\
\hline & $(\mathrm{C}-2-3) 18 \mathrm{bcc}-1$ & -0.95 \\
\hline \multirow[t]{2}{*}{ kc3 } & Obs9 & -3.06 \\
\hline & $(\mathrm{C}-3-6) 32 \mathrm{dbc}-1,(\mathrm{C}-3-6) 32 \mathrm{dbd}-1$ & -0.97 \\
\hline \multirow[t]{3}{*}{ krock3 } & Obs10 & -2.70 \\
\hline & Carr Fork Shaft & -1.80 \\
\hline & Obs11 & 1.36 \\
\hline \multirow[t]{2}{*}{$\mathrm{kc} 4$} & Obs13 & -2.50 \\
\hline & $(\mathrm{C}-2-3) 18 \mathrm{bcc}-1$ & -1.18 \\
\hline \multirow[t]{2}{*}{$\mathrm{kc1}$} & Obs14 & -2.44 \\
\hline & $(\mathrm{C}-4-4) 18 b b b-1$ & -1.79 \\
\hline \multirow[t]{3}{*}{ rech1 } & Obs 15 & 2.05 \\
\hline & $(\mathrm{C}-3-6) 32 \mathrm{dbc}-1,(\mathrm{C}-3-6) 32 \mathrm{dbd}-1$ & 1.2 \\
\hline & $(\mathrm{C}-3-3) 20 \mathrm{acb}-1,(\mathrm{C}-3-3) 20 \mathrm{bab}-1$ & 1.14 \\
\hline \multirow[t]{2}{*}{ kc5 } & Obs16 & -1.98 \\
\hline & (C-4-5)26dda-1 & -0.46 \\
\hline
\end{tabular}

\section{Results of Projection Simulations}

In the first projection simulation, ground-water levels in

the mountains rise because the average recharge simulated

stresses vary from stresses used during the calibration period, the more likely simulated water levels may not accurately represent actual system response. The ground-water system may respond in ways that are not simulated in these projections.

The first projection was used as a baseline to estimate water-level and water-quality changes if current ground-water withdrawals continue. The first projection simulated average precipitation (1971-2000) and 2003 ground-water withdrawal rates. An exception to using 2003 ground-water withdrawal rates was the TEAD extraction and injection wells, where reduced extraction and injection is expected in the future (Carl Cole, TEAD, oral commun., January 2007). Therefore, the 2003 rate was reduced by 50 percent in the projection simulations. Recharge from precipitation, irrigation, and streams was the long-term average. Recharge from North Willow Creek, South Willow Creek, and Box Elder Canyon streams was assumed to be negligible because a pipeline and reservoir system diverts and stores the water from these streams. Simulated ground-water budgets for the projected 36th year of simulation are listed in table 12 .

The second projection simulated recharge conditions with precipitation 90 percent of the 1971-2000 average precipitation. Simulated ground-water withdrawal rates are the same as in projection 1. Precipitation was 90 percent or less of the 1971-2000 average precipitation in 20 years from 1964 to 2004. Because consumptive use of plants uses a larger percentage of water when less water is available, a 10-percent reduction in precipitation produces a greater than 10-percent reduction in ground-water recharge. Calculations made during construction of the transient historical model indicated that recharge from precipitation and streams is 82 percent of the long-term average (an 18-percent reduction) when precipitation is 90 percent of the 1971-2000 average. Therefore recharge from precipitation and streams was simulated as 82 percent of long-term average during this projection. Recharge from irrigation on the Tooele Bench is estimated as only about 40 percent of the long-term average. The large variation in recharge in this area is evident in measured and simulated water-level changes (fig. 31, hydrographs D and Q).

The third projection simulated average precipitation conditions and ground-water withdrawal rates the same as 2003 except near Settlement and Middle Canyons. In those areas, the projection simulates the addition of seven wells near existing Tooele City public-supply wells with additional withdrawal of about 4,200 acre-ft/yr (about 145 percent of Tooele City withdrawal in 2003). Initial simulation showed that the increased withdrawals decreased baseflow in Settlement, Middle, and Pine Canyons by about 1,300 acre-ft/yr. To account for this change in streamflow, recharge from Middle Canyon Creek was reduced from about 1,000 to 960 acre-ft/ $\mathrm{yr}$, and recharge from irrigation on Tooele Bench was reduced from about 2,600 to 1,500 acre-ft/yr. 


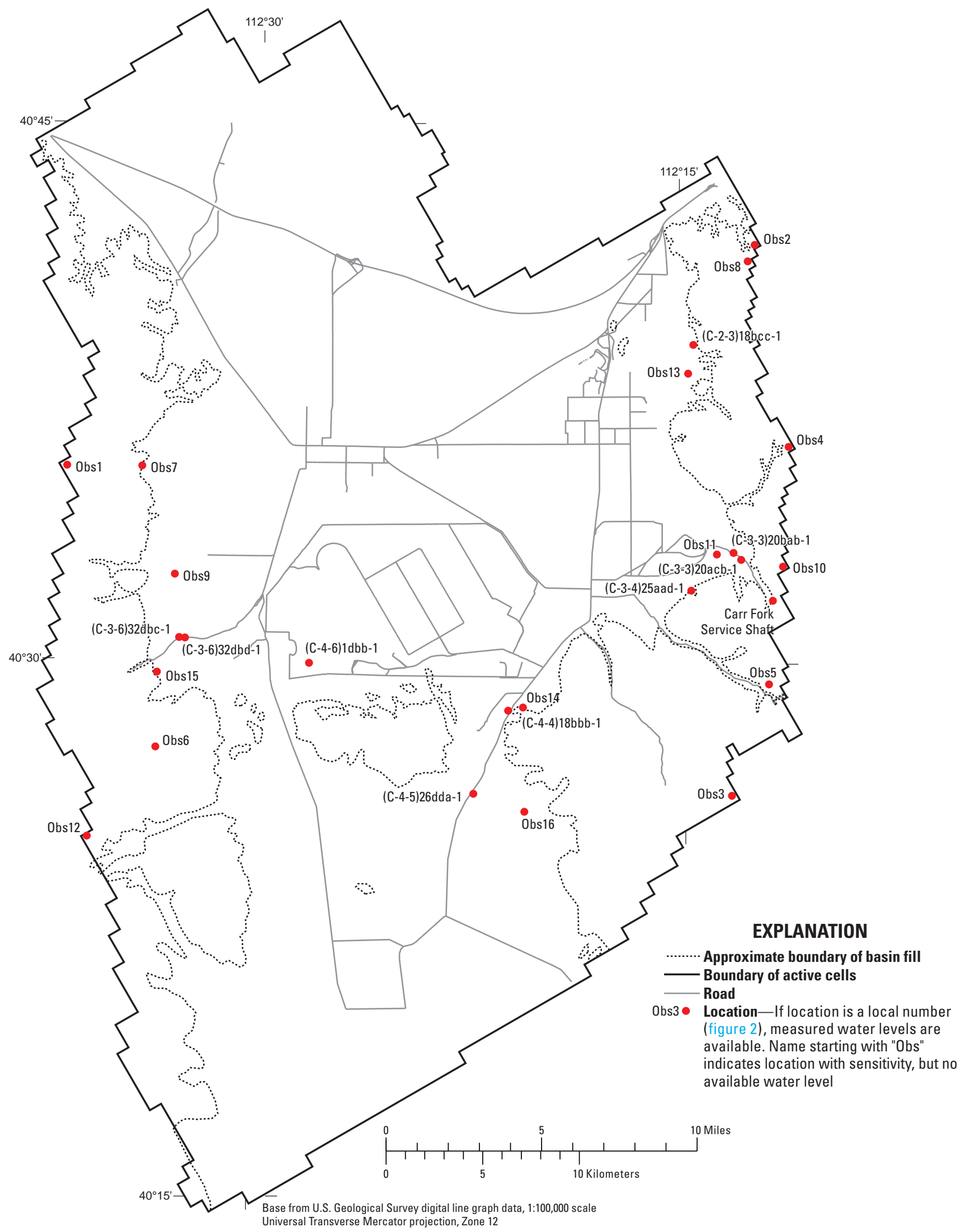

Figure 34. Location of simulated water levels with highest 1-percent scaled sensitivity in stress period 36 in layer 2 to selected model parameters, Tooele Valley ground-water basin, Tooele County, Utah. 


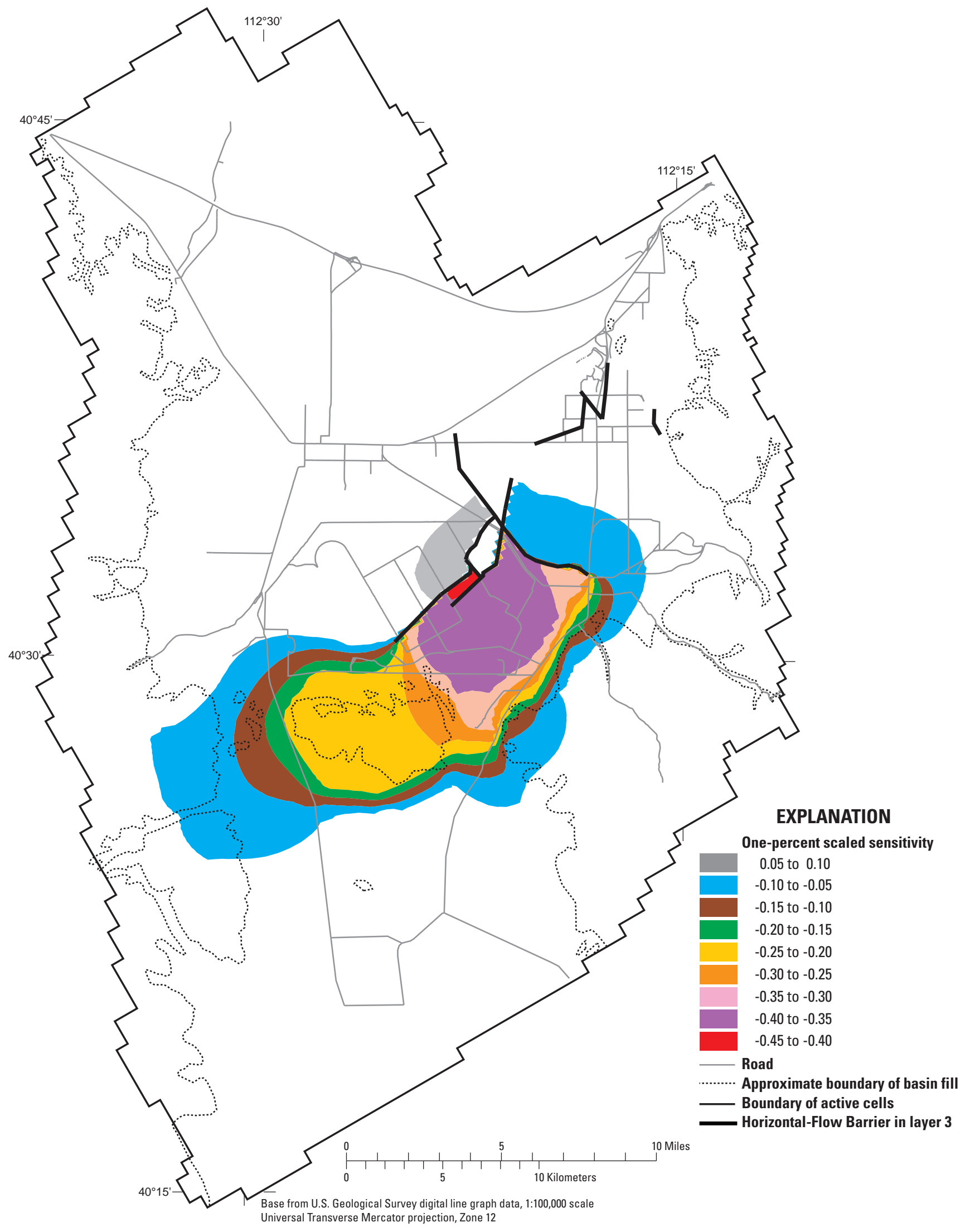

Figure 35. One-percent scaled sensitivity in stress period 36 in layer 2 to model parameter hfbtad1, Tooele Valley ground-water basin, Tooele County, Utah. 
(based on 1971-2000 average precipitation) is about 200 percent of recharge at the end of the transient historical simulation (based on 2003 precipitation). Ground-water levels in Tooele Valley rise near the mountains, rise slightly along the east side of the valley, but decrease throughout most of the western and southern portions of the valley (fig. 36). The greatest decline is about $25 \mathrm{ft}$ near the mouths of North Willow, South Willow, and Box Elder Canyons. Water levels in this area appear to be stabilizing from the effects of reduced recharge caused by the pipeline and reservoir system constructed in 1986. Water-level declines west of Tooele City range from about 10 to $15 \mathrm{ft}$; this is probably a result of municipal and TEAD withdrawals and reduced recharge from the southwest streams. Even though water levels in most areas increase during this simulation, the increase is minimal compared with historical fluctuations (fig. 37). In general, water levels remain about the same as those measured in March 2003. The simulated increase in storage during projection 1 is only about 40 percent of the simulated decrease in storage from March 2000 to April 2004 in the transient historical simulation, indicating that repeated years of average precipitation and recharge conditions do not completely restore the system after multiple years of belownormal precipitation.

In the second projection, ground-water levels at the end of 36 years are 0 to $275 \mathrm{ft}$ lower than with average recharge (projection 1) for 36 years (fig. 38). Water-level declines throughout most of Tooele Valley range from 0 to $20 \mathrm{ft}$, but are as much as $50 \mathrm{ft}$ near the mountains. Only about 1,200 acre-ft/yr of water is removed from storage in the 36th year of simulation, indicating near steady-state conditions. Waterlevel declines stabilize because discharge to streams, flowing wells, evapotranspiration, springs, and drains have decreased to equilibrate with the decreased recharge (figs. 39A and 39B). Even though the declines are greatest at the boundary of the model, boundary conditions are probably not influencing the water-level declines. During dry years, water levels on both sides of the mountain divide would probably decrease by about the same amount and additional flow likely would not be induced to Tooele Valley.

In the third projection, ground-water levels at the end of 36 years are 0 to $256 \mathrm{ft}$ lower than with average recharge and 2003 withdrawal rates for 36 years (fig. 40). The declines are concentrated near the increased withdrawal in southeastern Tooele Valley, exceed $10 \mathrm{ft}$ over most of the southeastern part of Tooele Valley, and are less than $5 \mathrm{ft}$ in other areas. Waterlevel declines may be influenced by boundary conditions along the eastern edge of the model where a no-flow boundary is simulated. It is possible that if water levels decline in this area, additional flow into Tooele Valley would be induced, and drawdowns would be less than simulated with the no-flow boundary. Only about 100 acre-ft/yr of water is removed from storage in the 36th year of simulation, indicating near

Table 12. Ground-water budget for model simulations, Tooele Valley ground-water basin, Tooele County, Utah.

[All flows in acre-feet per year, rounded; TEAD, Tooele Army Depot]

\begin{tabular}{|c|c|c|c|c|c|}
\hline Budget component & $\begin{array}{l}\text { Steady-state } \\
\text { simulation }\end{array}$ & $\begin{array}{l}\text { Transient simu- } \\
\text { lation, stress } \\
\text { period } 36\end{array}$ & $\begin{array}{c}\text { Projection 1, } \\
\text { stress period } \\
18\end{array}$ & $\begin{array}{c}\text { Projection 2, } \\
\text { stress period } \\
18\end{array}$ & $\begin{array}{c}\text { Projection 3, } \\
\text { stress period } \\
18\end{array}$ \\
\hline \multicolumn{6}{|c|}{ Recharge } \\
\hline Stream leakage & 7,500 & 3,100 & 5,600 & 4,600 & 5,600 \\
\hline Irrigation & 6,300 & 3,600 & 7,200 & 4,400 & 6,100 \\
\hline TEAD injection wells & 0 & 9,000 & 4,500 & 4,500 & 4,500 \\
\hline \multicolumn{6}{|c|}{ Discharge } \\
\hline Evapotranspiration & 24,500 & 25,000 & 25,600 & 22,600 & 25,200 \\
\hline Factory-Dunne Springs & 5,900 & 6,200 & 6,400 & 5,800 & 6,300 \\
\hline Mill Pond Spring & 3,000 & 3,500 & 3,600 & 3,000 & 3,200 \\
\hline Fishing Creek Spring & 2,200 & 2,700 & 2,600 & 1,700 & 2,100 \\
\hline Sixmile Spring & 2,400 & 2,800 & 2,700 & 2,000 & 2,300 \\
\hline Perennial streams in North Willow, South Willow, and Box Elder Canyons & 4,400 & 3,400 & 5,800 & 3,900 & 5,800 \\
\hline Perennial stream in Hickman Canyon and Clover Creek & 1,800 & 1,800 & 2,400 & 1,700 & 2,400 \\
\hline Perennial stream in Soldier Creek Canyon and Honerine Tunnel & 1,100 & 1,400 & 1,800 & 1,100 & 1,800 \\
\hline Small springs and drains & 1,200 & 1,200 & 1,100 & 800 & 900 \\
\hline Great Salt Lake & 1,000 & 1,000 & 1,000 & 900 & 1,000 \\
\hline Shaft and mine dewatering & 0 & 700 & 700 & 700 & 700 \\
\hline Total & 71,800 & 85,500 & 87,000 & 71,900 & 85,800 \\
\hline \multicolumn{6}{|c|}{ Change in Storage } \\
\hline Water coming out of (-) or going into $(+)$ storage & & $-32,300$ & 300 & -900 & 200 \\
\hline Total water out of $(-)$ or into $(+)$ storage during 36 years of simulation & & $-3,400$ & 52,700 & $-117,500$ & 16,900 \\
\hline
\end{tabular}




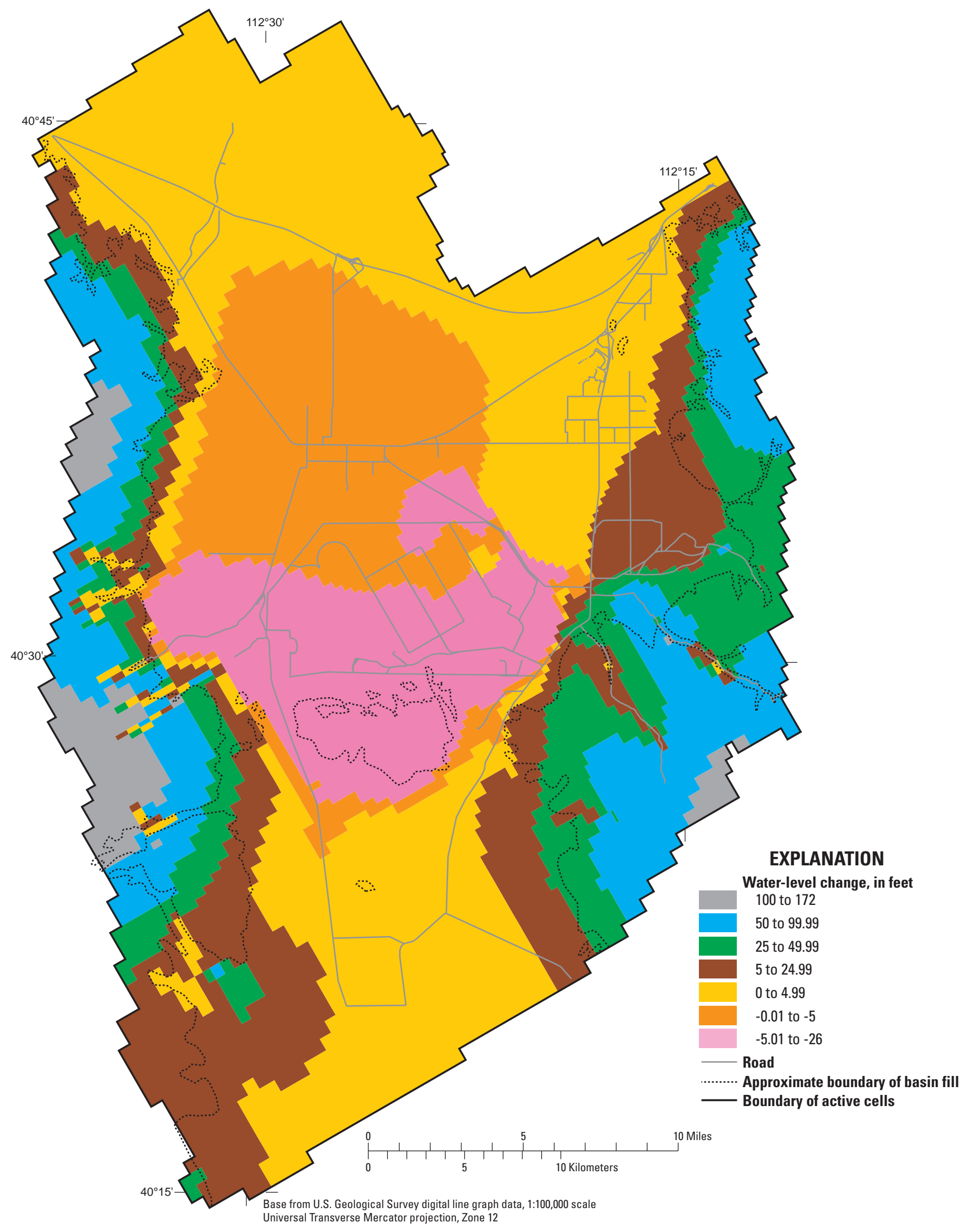

Figure 36. Water-level change in model layer 2 at the end of 36-year simulation (stress period 18), projection 1 of the ground-water flow model, Tooele Valley ground-water basin, Tooele County, Utah. 

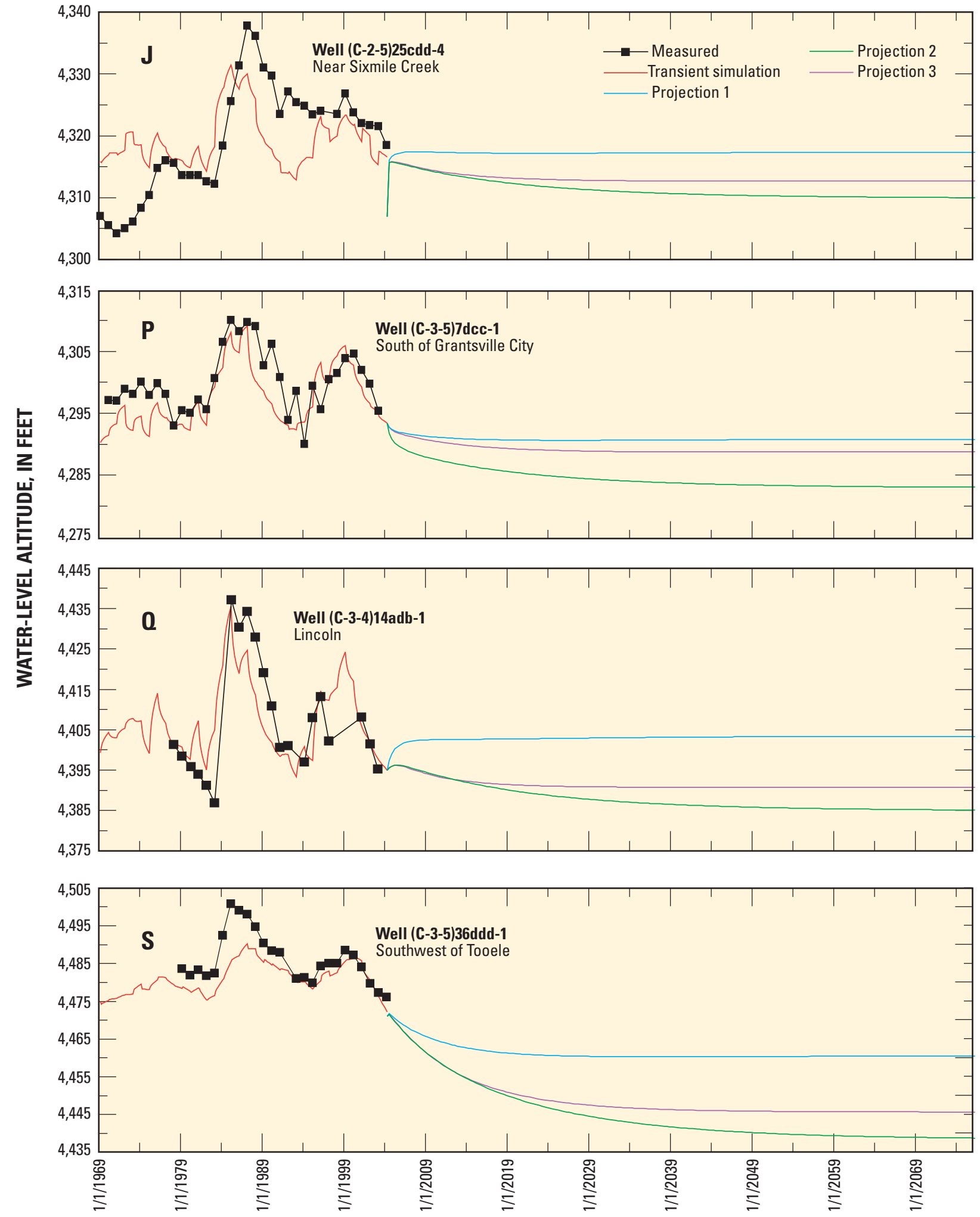

See figure 30 for site locations

Figure 37. Water levels simulated in the transient and projection ground-water flow models and water levels measured from March 1969 to April 2004 for four selected sites, Tooele Valley ground-water basin, Tooele County, Utah. 


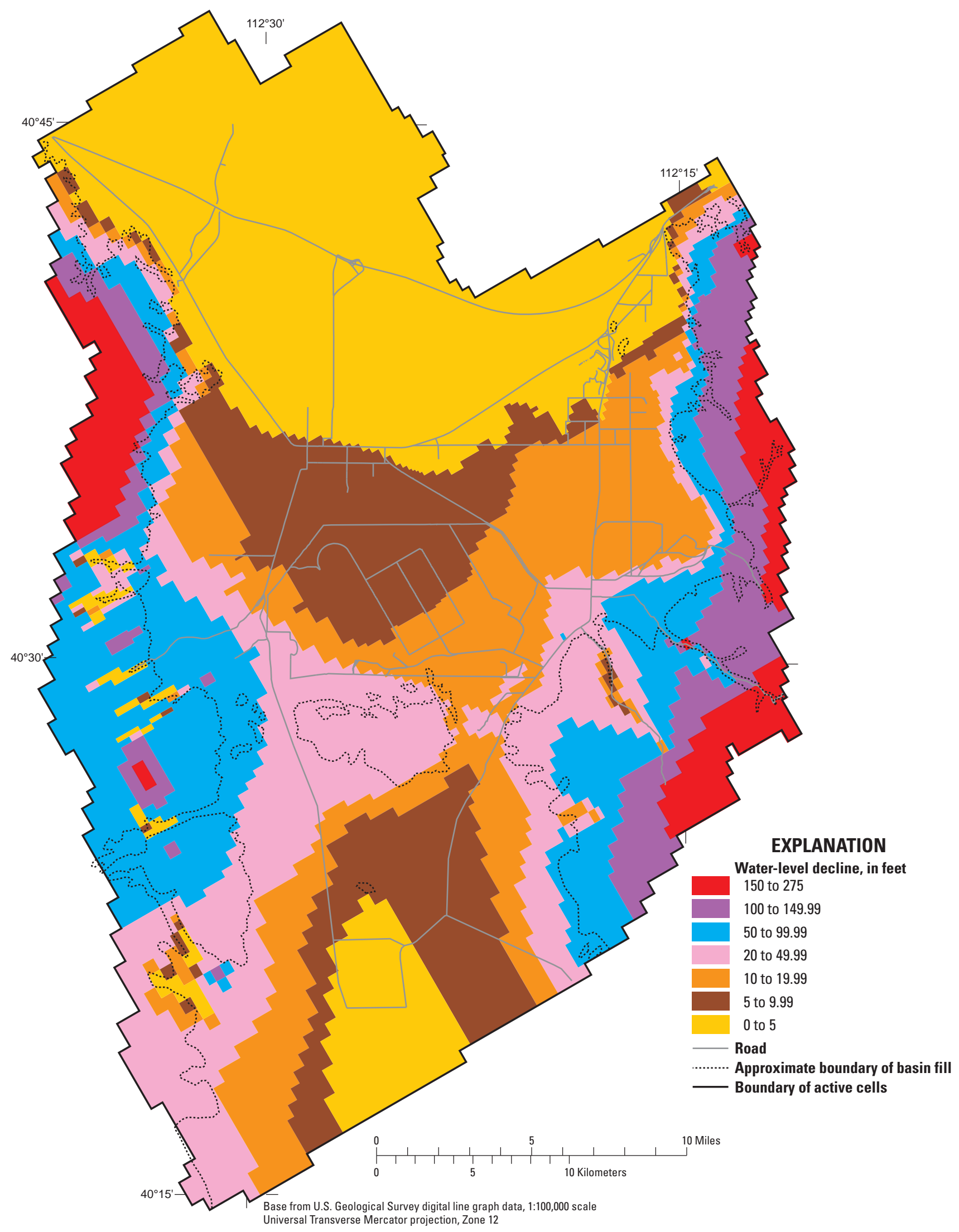

Figure 38. Difference in water levels in model layer 2 at the end of 36-year simulation (stress period 18) between projection 1 and projection 2 of the ground-water flow model, Tooele Valley ground-water basin, Tooele County, Utah. 


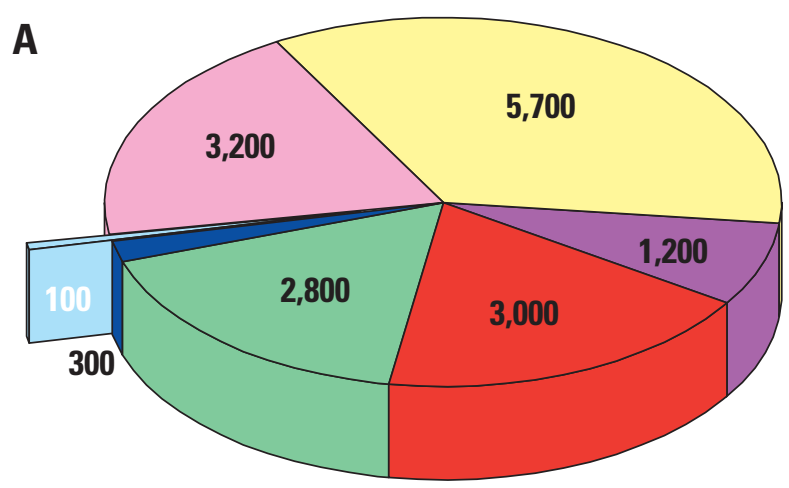

B

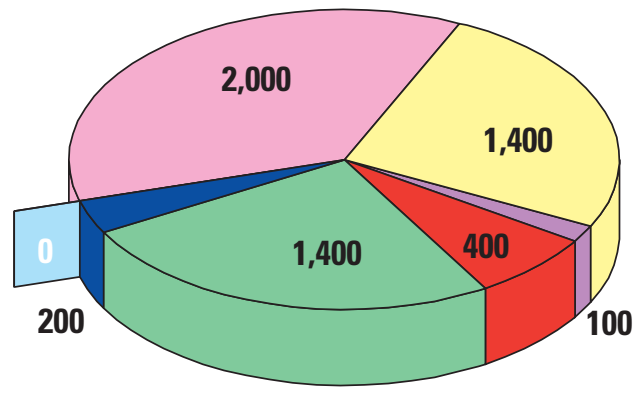

EXPLANATION

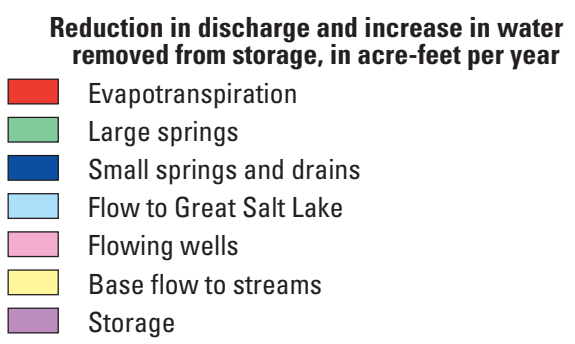

Figure 39. Decreased discharge and increase in water removed from storage at the end of 36-year simulation (stress period 18) because of (A) decreased recharge, projection 2 and (B) increased withdrawal, projection 3 of the ground-water flow model, Tooele Valley ground-water basin, Tooele County, Utah.

steady-state conditions. Discharge to flowing wells, streams, springs, evapotranspiration, and drains have decreased a total of about 5,500 acre-ft/yr in response to increased withdrawal and decreased recharge in the Tooele area. (fig. 39).

\section{Direction of Flow}

Water managers have been concerned that increasing ground-water withdrawals in the southeastern part of Tooele Valley may change the direction of flow and cause water to move from areas of ground water with dissolved-solids concentration in excess of $1,000 \mathrm{mg} / \mathrm{L}$ to municipal wells. Utah drinking-water standards require that if dissolved-solids concentration is greater than $1,000 \mathrm{mg} / \mathrm{L}$, the supplier shall satisfactorily demonstrate that no better water is available (Utah Department of Environmental Quality, Division of Drinking Water, 2005, p. 5). The USGS computer program MODPATH
(Pollock, 1994) was used to simulate the movement of water particles through the ground-water system using the output from the MODFLOW simulations. It is assumed that any contaminants in the water are transported with the water particle. For the MODPATH simulations, layers 1 and 2 were simulated as confined and the top of the layers was defined as the simulated water level after 36 years of projection simulation.

From data presented by Steiger and Lowe (1997, sheet 1), areas of dissolved-solids concentration in excess of 1,000 $\mathrm{mg} / \mathrm{L}$ in the top $150 \mathrm{ft}$ of saturated basin fill were delineated in model layer 2 (fig. 41). From data presented by Steiger and Lowe (1997, sheet 3), areas of dissolved-solids concentration in excess of $1,000 \mathrm{mg} / \mathrm{L}$ deeper than $150 \mathrm{ft}$ of saturated basin fill were delineated in model layers 3, 4, and 5 (fig. 41). These areas were used in MODPATH as starting locations for particles. One particle was placed in each model cell in the affected layers. The particles were tracked in the forward direction for the 72-yr duration of the three projection simulations described above. Using this approach, simulated particles moving out of the area of greater than $1,000 \mathrm{mg} / \mathrm{L}$ indicate a movement of the poor quality water into other areas.

In all projections, the particles of water in the central part of the valley typically move north-northwest and remain in the area of high dissolved-solids concentration (fig. 42). Exceptions occur at the south end of the zone, where particles move northeast before turning north, and on the east side of the zone, where particles move farther north than the zone of high dissolved-solids concentration. Particles from the small area of high dissolved-solids concentration on the east side of the valley leave the area to both the west and the north. Little difference could be detected in the movement of particles among the three projections, indicating that reduced recharge or increased withdrawal do not change the direction of ground-water flow from areas of high dissolved-solids concentration.

\section{Model Analysis of Environmental Tracers}

To determine if the model adequately simulates flow paths and time-of-travel, MODPATH (Pollock, 1994) was used to determine the source and age of water from three select locations in the model that correspond to estimated sources by tracking particles backward. For these analyses, the transient historical model was used, but the time length of the first steady-state period was changed to 10,000 years to allow time for the particles to travel backward to their source. Model layers 1 and 2 were simulated as confined, and the top of the layers was defined as the simulated steady-state water level. First, particles were tracked back to their source from the area east of Erda (fig. 43). The paths indicate that almost all recharge to model layer 2 in this area is from irrigation or low-altitude bench recharge, not from mountain-block flow to unconsolidated basin fill or from direct infiltration of streamflow at the mountain front. This is consistent with the analysis of ${ }^{2} \mathrm{H}$ and ${ }^{18} \mathrm{O}$ data of the source of water in this area (fig. 14). The time from recharge to discharge as determined 


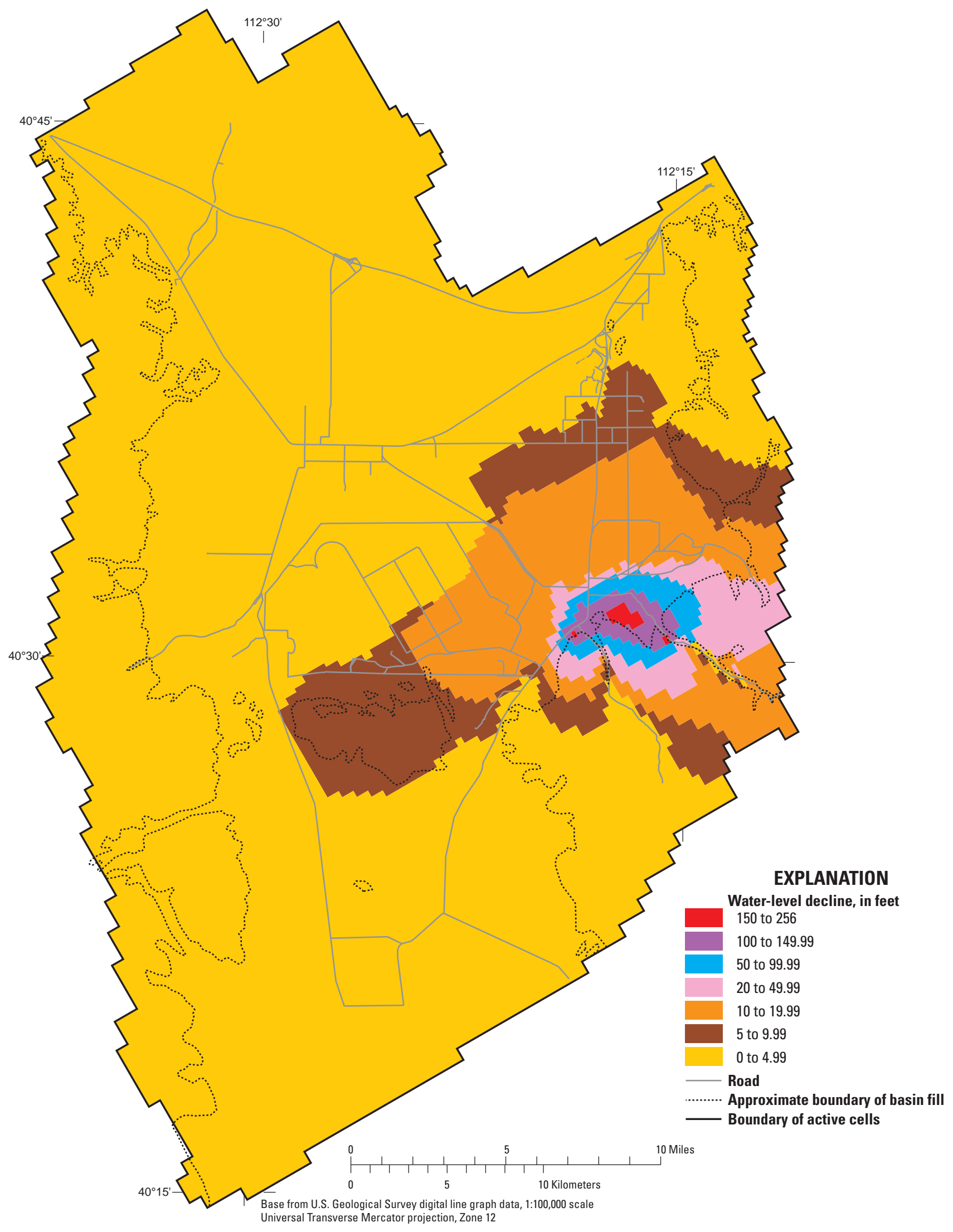

Figure 40. Difference in water levels in model layer 2 at the end of 36-year simulation (stress period 18) between projection 1 and projection 3 of the ground-water flow model, Tooele Valley ground-water basin, Tooele County, Utah. 


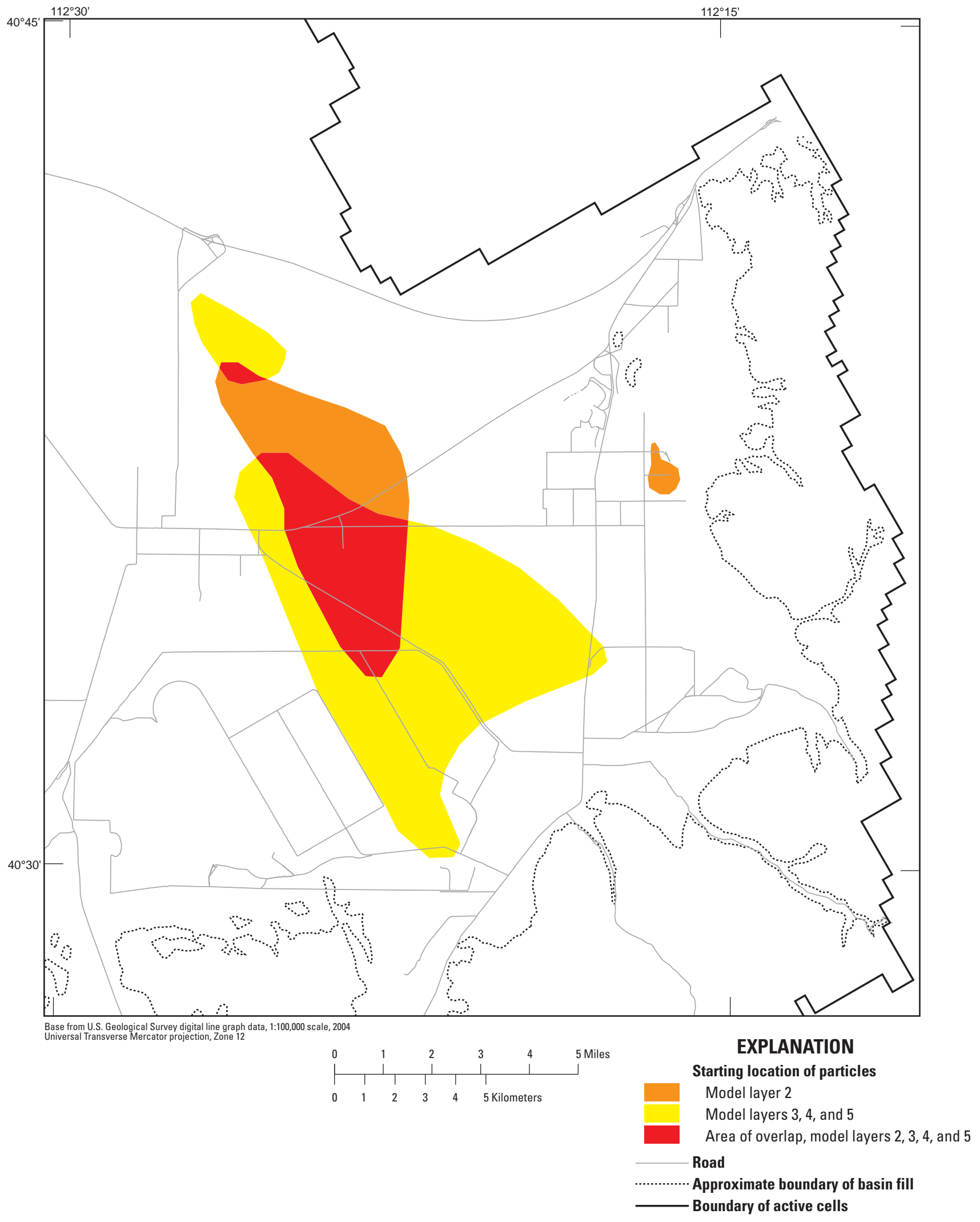

Figure 41. Simulated starting locations of particles in areas of dissolved-solids concentration greater than 1,000 $\mathrm{mg} / \mathrm{L}$, Tooele Valley ground-water basin, Tooele County, Utah. 


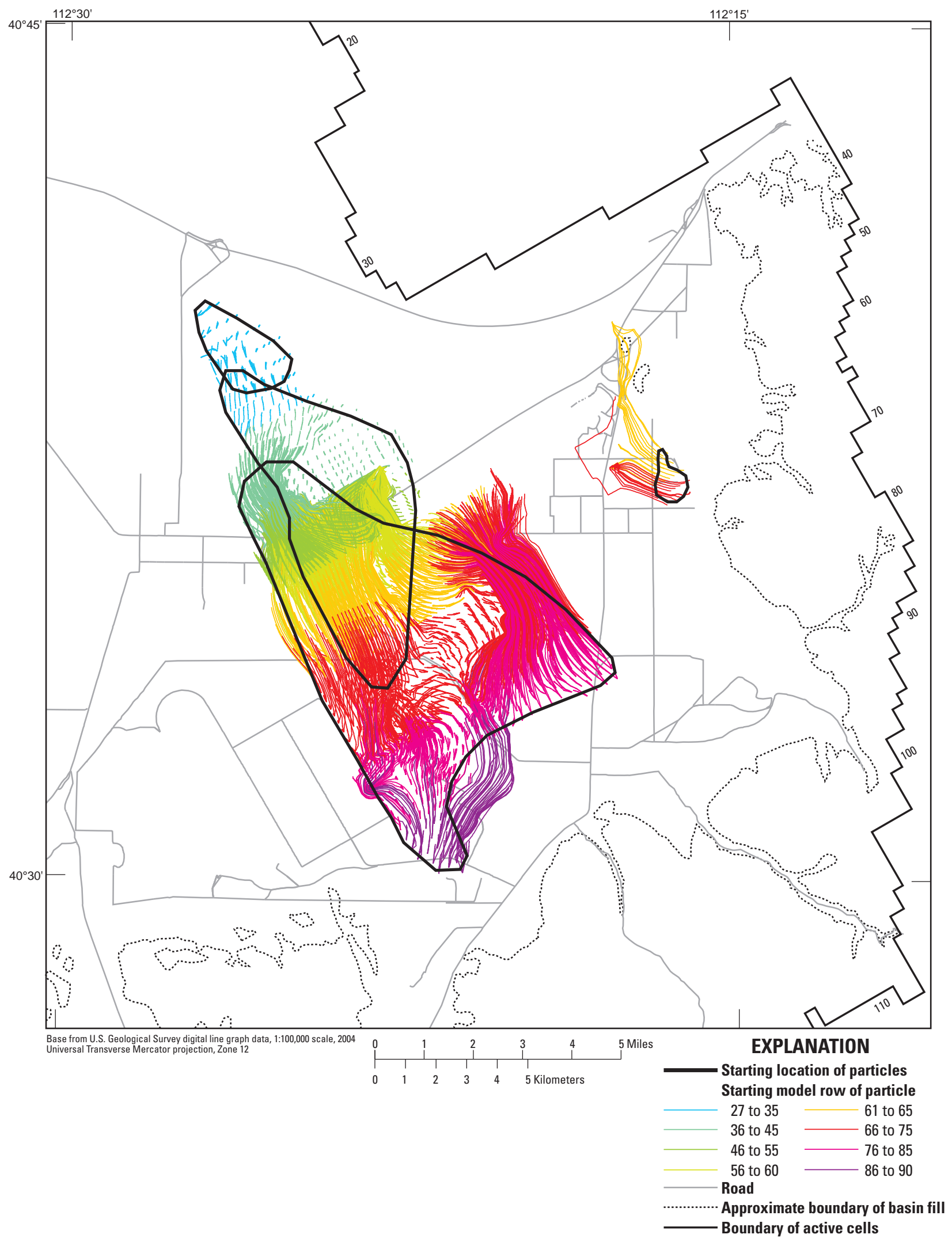

Figure 42. Simulated flow paths of particles started in areas of dissolved-solids concentration greater than 1,000 mg/L, projection 1 of the ground-water flow model, Tooele Valley ground-water basin, Tooele County, Utah. 
by MODPATH ranges from 16 to 305 years (with the exception of one particle), and increases from south to north. This is consistent with the presence of tritium in water collected from wells in the southern part of this area and absence of tritium in water collected from wells in the northern part of this area (fig. $15)$.

Second, particles were tracked back to their source from two deep wells in the Stansbury area and two wells south of Grantsville City (fig. 44). The model results indicate that water in the deep wells in the Stansbury area derives from the Middle Canyon area, and that water in the wells south of Grantsville City derives from the area where creeks from North Willow, South Willow, and Box Elder Wash contribute water directly to the unconsolidated basin fill. These simulated sources of mountain block or direct infiltration of streamflow are consistent with the ${ }^{2} \mathrm{H}$ and ${ }^{18} \mathrm{O}$ data (fig. 14). Water produced from the wells in Stansbury Park is simulated to be from 760 to 2,800 years old, which is consistent with the lack of tritium in the water collected from those wells (fig. 15). The water from the wells south of Grantsville City is simulated to be 350 to 930 years old, which is consistent with the pre-modern age of water determined from isotopic analysis.

In addition to the backward particle tracking to determine the source of water to selected areas, particle tracking was used to determine whether the model adequately represents the area of faster flow from the southeast to northwest as suggested by the tritium data (fig. 15). Particles were placed in a line across the valley from about Sixmile Spring to Erda and MODPATH was used to simulate backward tracking (fig. 45). The model reasonably simulates the direction of flow and indicates that the area from southeast to northwest has higher velocities, but the simulated rates of flow are much slower than indicated by the tritium data. Possible reasons for the discrepancy are that preferential flow paths in the horizontal and vertical directions are not simulated, porosity is less than the simulated 0.20 , or that hydraulic conductivity at depth is less and hydraulic conductivity in shallower deposits is greater than simulated. Decreasing hydraulic conductivity with depth would allow the overall simulated gradient to remain the same, but would allow water in the top model layer to move faster. Not enough geological or water-level data are available, however, to justify this level of model refinement.

\section{Model Limitations}

The numerical model is a simplified representation of the ground-water system and does not represent local heterogeneity in aquifer properties, recharge, or discharge. Although consolidated rock is simulated, it is simulated as porous media, not as a fracture-flow system. The hydraulic conductivity of consolidated rock is extremely heterogeneous, and this model does not accurately simulate possible fracture flow to wells and tunnels. Simulated horizontal hydraulic conductivity is determined by equation 3 . Because the percentage of saturated basin fill is set at a constant value, hydraulic-conductivity values in each cell do not change during the simulation. This causes an inaccuracy in simulated water levels near the boundary between basin fill and consolidated rock, especially near pumping wells.

In general, ground-water flow models can be considered more accurate representations of the ground-water system in areas where simulated flow and water levels more closely match available data. Because of the lack of data in the southwestern part of Tooele Valley and in consolidated rock, the model may not be accurate in those areas, and estimates of flow rates, water levels, or changes in the ground-water system in those areas are considered less accurate than where the model closely matches measured data.

Two areas have the greatest model inaccuracies that may limit the ability of the model to accurately simulate potential changes in the ground-water system. Both the area around Erda and Rush Valley have simulated water levels above land surface in layer 1. A better understanding of irrigation, evapotranspiration, and vertical hydraulic conductivity may help refine the model in those areas. The area around Erda has the additional complication of an extremely steep hydraulic gradient that may not be simulated correctly. Measured discharge to Mill Pond Spring increased disproportionately compared with measured discharge to other major springs and to the simulated increase in discharge to springs (fig. 33). It is possible that additional sources of water not simulated in this model may contribute flow to Mill Pond Springs. These could include irrigation with Tooele City wastewater south of Erda and lawn irrigation in the Stansbury Park area. It is also possible that the measured increase is incorrect because of difficulties in locating and operating the gage.

Near Grantsville City, it appears that something other than climate fluctuations is causing measured water-level declines. The model simulates decreased recharge from irrigation because of the reservoir and pressurized irrigation system after 1986, and increased withdrawals in 2000 through 2003, but simulated declines are less than measured declines. Waterlevel fluctuations in this area are underestimated in the transient historical simulation, and the model may not accurately predict changes in the ground-water system in this area.

The aquifer characteristics simulated in this model are reasonable approximations of the actual aquifer characteristics on the basis of available data. In general, the parameters are considered to be independent of one another. Several parameters, however, are highly correlated and may not be independent of one another (table 13). Specific storage in layer 2 and specific storage in layers 3, 4, and 5 in the Stansbury Mountains are perfectly correlated and cannot be estimated individually. The other highly correlated pairs all include either pumpage, tadpump, or both. An increase in groundwater withdrawals and an increase in irrigation recharge or hydraulic conductivity could yield a similar model. As long as withdrawal and injection are accurately simulated, the other parameters are more likely to be unique. For instance, it is not likely that increasing both recharge and hydraulic conductivity would cause simulated water levels and discharge to be similar to water levels and discharge simulated by this model. 


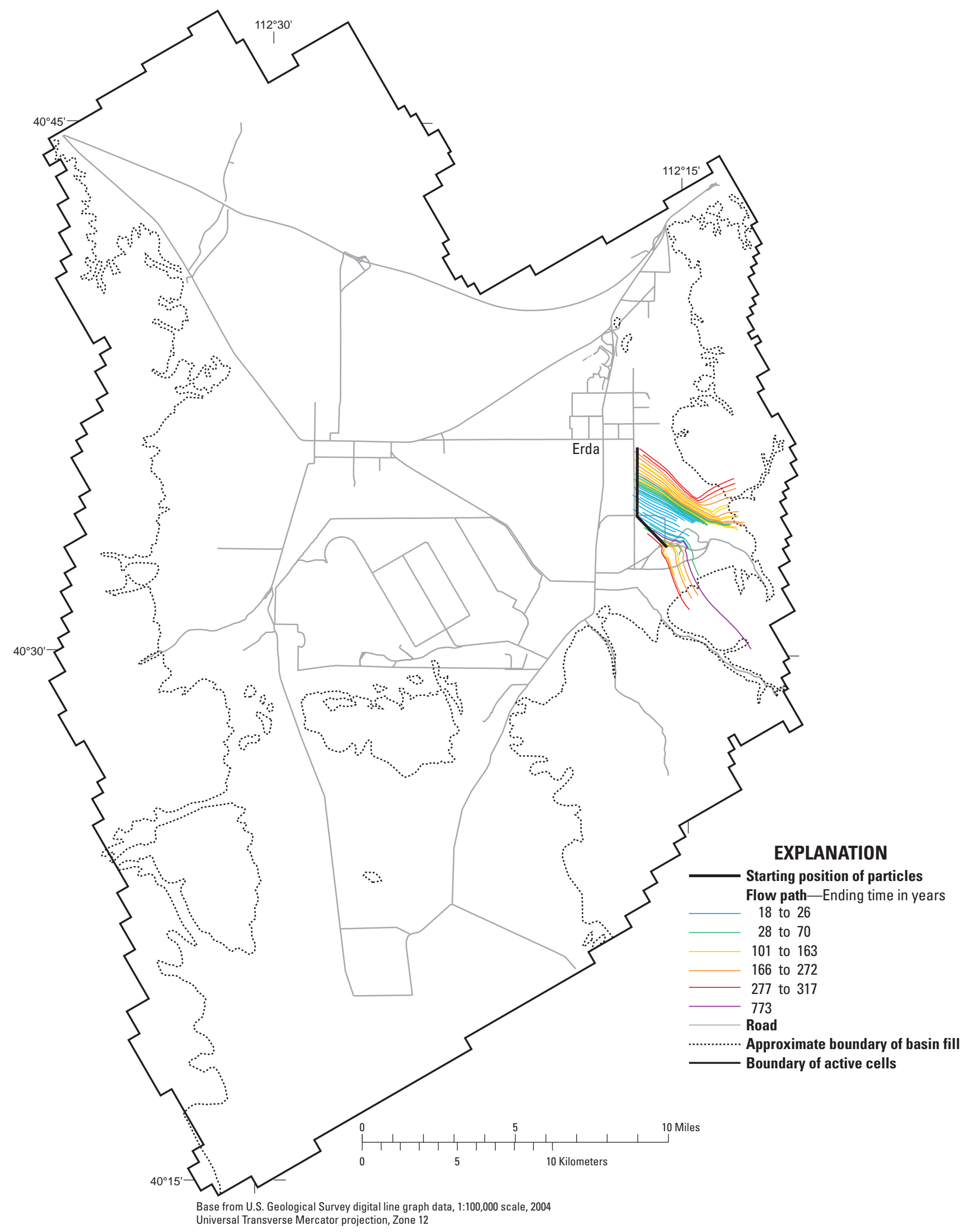

Figure 43. Simulated backward flow paths of particles started in the area east of Erda, Tooele Valley ground-water basin, Tooele County, Utah. 


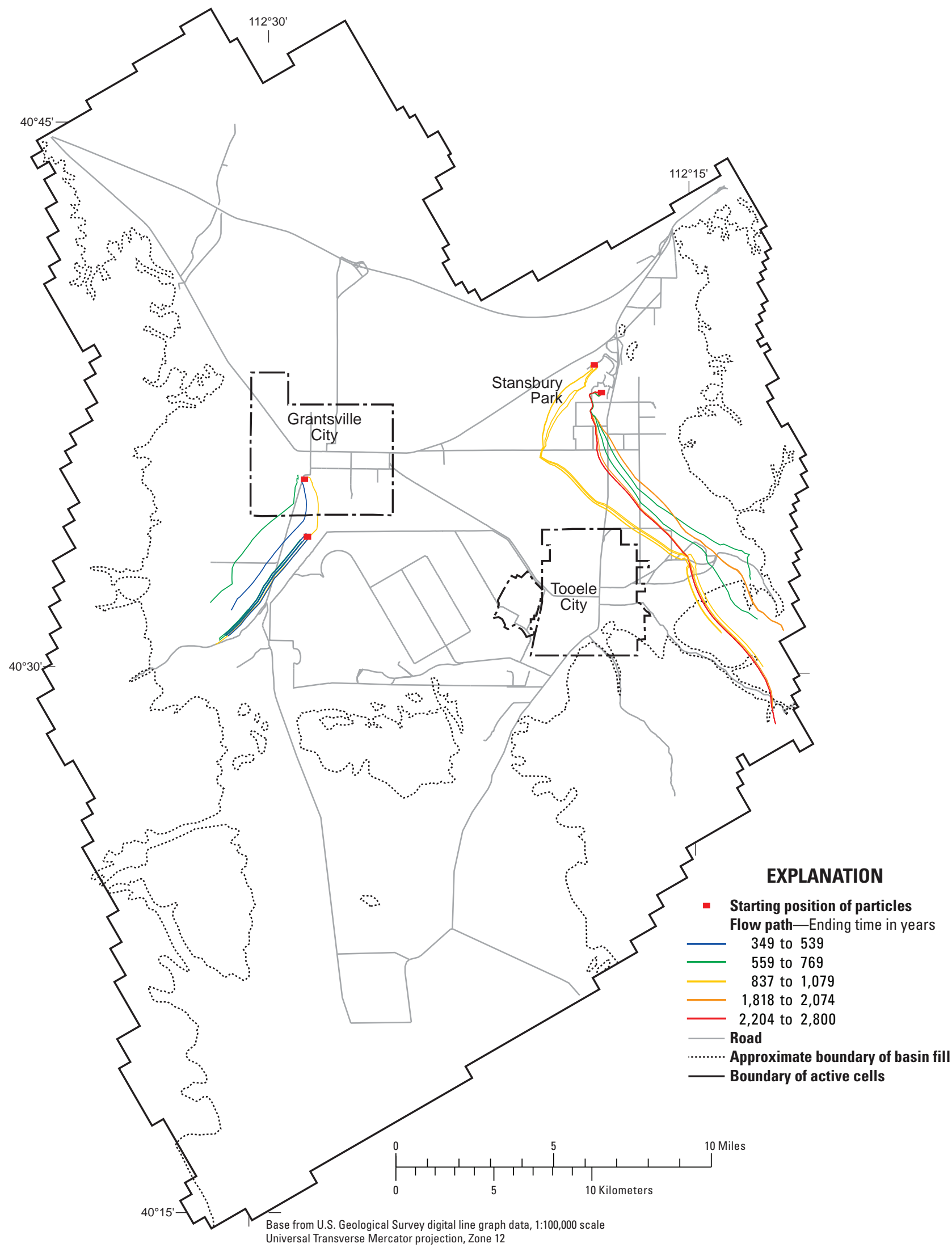

Figure 44. Simulated backward flow paths of particles started near two wells in Stansbury Park and two wells south of Grantsville City, Tooele Valley ground-water basin, Tooele County, Utah. 


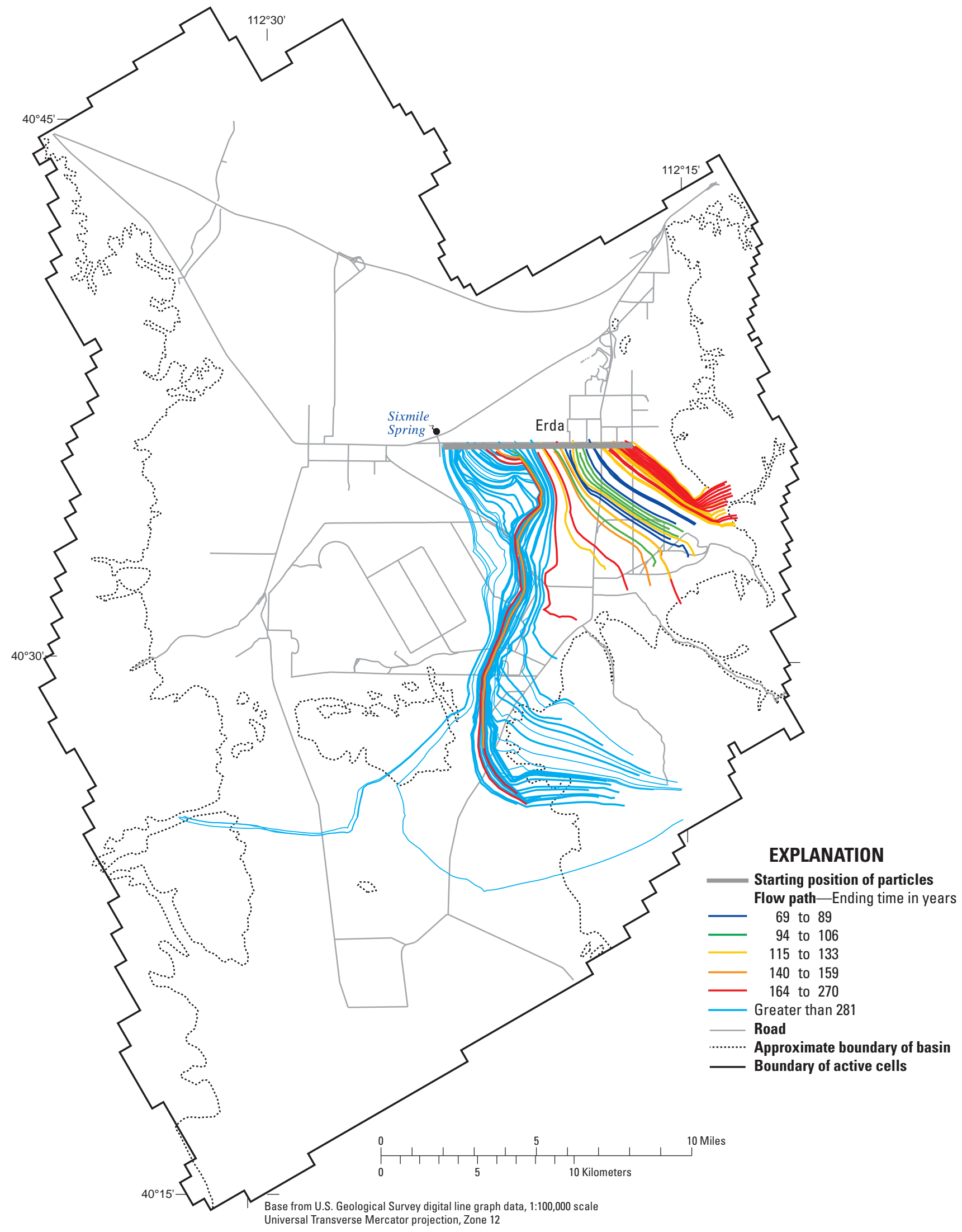

Figure 45. Simulated backward flow paths of particles started along an east-west line, Tooele Valley ground-water basin, Tooele County, Utah. 
It is possible, however, that other combinations of recharge, discharge, and aquifer characteristics may yield a similar or improved match to measured water levels. The conceptual rate of recharge and ground-water withdrawal from wells was not varied in the model. The final values of all model parameters are based on those values. Calibrating to different rates or distribution of recharge and ground-water withdrawal could change the final values of the calibration parameters.

Table 13. Highly correlated parameters in the ground-water flow model, Tooele Valley ground-water basin, Tooele County, Utah.

\begin{tabular}{ccc}
\hline $\begin{array}{c}\text { Parameter } \\
\text { (from table C6) }\end{array}$ & $\begin{array}{c}\text { Parameter } \\
\text { (from table C6) }\end{array}$ & Correlation \\
\hline ss1 & ss2 & -1.00 \\
pumpage & tadpump & 0.96 \\
grantsirr & pumpage & 0.95 \\
tadpump & kc7 & 0.94 \\
grantsirr & tadpump & 0.93 \\
carrfork & pumpage & 0.93 \\
tadpump & hfbtad1 & 0.92 \\
tadpump & krock6 & 0.91 \\
\hline
\end{tabular}

Projection simulations can be considered the most accurate where the transient historical simulation most closely matches measured water levels. Because measured water levels in the mountains do not exist, the changes in water levels in the mountains cannot be verified. Projections 1 and 2 show the largest declines in the southern part of Tooele Valley (figs. 36 and 38) where few long-term water-level data exist (fig. 30). Additional data collection in this area would indicate the accuracy of the model in this area.

Despite the limitations, the accuracy of this model to simulate the regional effects of changes in the ground-water system is considered good. Improvements over previous models (Lambert and Stolp, 1999) have been made by incorporating the consolidated rock and horizontal-flow barriers, and by simulating more annual variation in recharge from precipitation, streamflow, and irrigation. This model should not be considered static. Better estimates of recharge and baseflow in streams may indicate a different value of hydraulic conductivity of consolidated rock. New data collection could help refine the conceptual understanding and numerical model of the study area. Ground-water withdrawals in new areas could induce new horizontal or vertical gradients that may reveal different aquifer characteristics. The adjustment of model parameters in the TEAD area, for which data are relatively plentiful, is indicative of how additional data may warrant revision of the numerical model.

\section{Summary}

Ground water is the sole source of drinking water within Tooele Valley. Both land and water resources that have traditionally been used for agricultural purposes are now being converted to residential and municipal use, and this transition will affect Tooele Valley water resources. Management of water resources under these changing conditions requires additional understanding of spatial and vertical distribution of water resources, and specifically the quantity, quality, and sustainability of ground water. To improve the understanding of water resources in Tooele Valley, the U.S. Geological Survey (USGS), in cooperation with Tooele County, conducted a hydrologic study of the Tooele Valley ground-water basin. The study period extended from 2003 to 2006.

The Tooele Valley ground-water basin is conceptualized as a single interconnected hydrologic system consisting of the consolidated-rock Oquirrh and Stansbury Mountains and adjoining unconsolidated basin fill in northern Rush Valley and Tooele Valley. There are eight perennial streams in the ground-water basin with estimated average annual streamflow greater than 500 acre-feet per year. The major sources of streamflow are runoff and baseflow with snowmelt being the largest component of runoff. A comparison of percentages indicates that measured streamflow has a greater variability than precipitation.

Within the basin fill, unconfined conditions exist along the valley margins and confined conditions exist in the central areas of the valleys. Transmissivity values of the unconsolidated basin fill are estimated to range from 1,000 to 270,000 square feet per day. Within the consolidated rock of the mountains, ground water is presumed to exist under unconfined conditions. Variability in geologic structure, stratigraphy, and lithology has almost certainly created some areas where ground water is perched and(or) confined. Hydraulic conductivity of the consolidated rock ranges from 0.003 to 100 feet per day.

Ground water within the basin generally moves from the mountains toward the central and northern areas of Tooele Valley. Steep hydraulic gradients exist at Tooele Army Depot and near Erda. Average annual ground-water recharge within the basin is estimated to be 82,000 acre-feet per year. Recharge is primarily from precipitation in the mountains; other sources of recharge are irrigation water and streams. Recharge from precipitation was determined using the Basin Characterization Model. Completion of Grantsville reservoir in 1986 reduced the recharge from irrigation in the Grantsville City area. It is likely that the water-level declines observed in the area since the late 1990s are a direct result of this decrease in recharge.

The average annual ground-water discharge within the basin is estimated to be 84,000 acre-feet per year. Discharge is by withdrawal for irrigation, industrial, public supply, and domestic and stock wells; discharge to springs and drains, and evapotranspiration. Flowing well discharge was re-evaluated and the estimated amount reduced from previous assessments. As of 2005, 12 large flowing wells incorporated in previous assessments were either capped or equipped with pumps. Evapotranspiration is the largest component of discharge from the ground-water basin. Evapotranspiration rates used to calculate discharge were determined on the basis of measured rates in Nevada and California. 
Annual water-level fluctuations at wells within the basin indicate periods of increased recharge during 1983-1984 and 1996-2000. These periods coincide with times when annual precipitation at Tooele City exceeded the 1971-2000 annual average for consecutive years. Water levels at wells in northern Rush Valley and at Tooele are did not fluctuate seasonally during 2002-2004. The lack of seasonal variation in northern Rush Valley indicates a degree of hydraulic isolation from both recharge in the nearby mountains and localized discharge to wells. The lack of seasonal variability at Tooele may be due to less-than-average precipitation for 2002-2004.

The water with the lowest dissolved-solids concentrations exists in the mountain areas where most of the groundwater recharge occurs. The principal dissolved constituents are calcium and bicarbonate. Dissolved-solids concentration increases in the central and northern parts of Tooele Valley, at the distal ends of the ground-water flow paths. Increased concentration is due mainly to greater amounts of sodium and chloride. Deuterium and oxygen-18 values indicate water recharged primarily from precipitation occurs throughout the ground-water basin. Ground water with the highest percentage recharge from irrigation exists along the eastern margin of Tooele Valley, indicating negligible recharge from the adjacent consolidated rock.

Tritium and tritiogenic helium-3 concentrations indicate modern water (recharged after the mid 1950s) exists along the flow paths originating in the Oquirrh Mountains between Settlement and Pass Canyons and extending between the steep hydraulic gradient areas at Tooele Army Depot and Erda. Pre-modern water (water with an apparent age of greater than 50 years) exists in areas east of Erda and near Stansbury Park. Using the change in tritium along the flow paths originating in the Oquirrh Mountains, a first-order estimate of average linear ground-water velocity for the general area is roughly 2 to 5 feet per day.

A numerical ground-water flow model was developed to simulate ground-water flow in the Tooele Valley ground-water basin and test the conceptual understanding of the groundwater system. Simulating consolidated rock allows recharge and withdrawal from wells in or near consolidated rock to be more accurately simulated and also allows for more accurate simulation of the location and movement of recharge. The steady-state period of the ground-water flow model adequately simulates water levels observed in March 1969. In general, the model accurately simulates water levels and water-level fluctuations from 1969 to 2004 and can be considered an adequate tool to help determine the valley-wide effects on water levels of additional ground-water withdrawal and changes in water use. The ground-water model also adequately simulates flow paths and recharge sources as indicated by environmental tracers such as deuterium, oxygen-18, and tritium.

The ground-water flow model was used to estimate possible effects on water levels and water quality caused by lessthan-normal precipitation and streamflow and by increased withdrawal from wells. The simulated increase in storage during the projection using 2003 ground-water withdrawal data and 30-year average recharge data indicates that repeated years of average precipitation and recharge conditions do not completely restore the system after multiple years of belownormal precipitation. Water levels throughout most of Tooele Valley are projected to be as much as 50 feet lower when precipitation is 90 percent of the 30 -year average than when precipitation is the 30-year average. Water levels are projected to be at least 10 feet lower and as much as 260 feet lower over most of the southeastern part of Tooele Valley with increased withdrawals in that area. Particle tracking indicates that projected reduced recharge or increased withdrawal does not change the direction of ground-water flow from areas of high dissolved-solids concentration.

\section{References Cited}

Aeschbach-Hertig, W., Peeters, F., Beyerle, U., and Kipfer, R., 2000, Paleotemperature reconstruction from noble gases in ground water taking into account equilibrium with trapped air: Nature, v. 405, p. 1044.

Asch, T.H., 2005, Summary and integration of geophysical investigations of the Tooele Army Depot (TEAD), Tooele, Utah: U.S. Geological Survey Open-File Report 05-1338, $53 \mathrm{p}$.

Anderson Engineering Company, Inc., 2002, IS\&R/Carr Fork remedial investigation potential for elevated arsenic at the Price well as a result of the Carr Fork Mine dewatering: Salt Lake City, Utah, Anderson Engineering Company, Inc., variously paged.

Anderson Engineering Company, Inc., 2004, International Smelting and Refining/Carr Fork Site remedial investigation report: Salt Lake City, Utah, Anderson Engineering Company, Inc., variously paged.

Berger, D.L., Johnson, M.J., Tumbusch, M.L., and Mackay, J., 2001, Estimates of evapotranspiration from the Ruby Lake National Wildlife Refuge Area, Ruby Valley, northeastern Nevada, May 1999-October 2000: U.S. Geological Survey Water-Resources Investigations Report 01-4234, 38 p.

Biek, R.F., 2005, The Traverse Mountains_-new geologic maps and explosive suburban growth: Utah Geological Survey, Survey Notes, v. 37, no. 2, 13 p.

Bradbury, K.R., and Rothschild, E.R., 1985, A computerized technique for estimating the hydraulic conductivity of aquifers from specific capacity data: Ground Water, v. 23, no. 2, p. $240-246$.

Brooks, L.E., and Mason, J.L., 2005, Hydrology and simulation of ground-water flow in Cedar Valley, Iron County, Utah: U.S. Geological Survey Scientific Investigations Report 05-5170, 114 p. 
Brooks, L.E., and Stolp, B.J., 1995, Hydrology and simulation of ground-water flow in southern Utah and Goshen Valleys, Utah: Utah Department of Natural Resources Technical Publication no. 111, 96 p.

Burden, C.B., and others, 2007, Ground-water conditions in Utah, spring of 2007: Utah Department of Natural Resources, Division of Water Resources, Cooperative Investigations Report no. 48, 129 p.

Carpenter, E., 1913, Ground water in Boxelder and Tooele Counties, Utah: U.S. Geological Survey Water-Supply Paper 333, 90 p.

Craig, H., 1961, Standard for reporting concentrations of deuterium and oxygen-18 in natural waters: Science, v. 133, no. 3467 , p. 1833-1834.

Dansgaard, W., 1964, Stable isotopes in precipitation: Talus, v. 16, p. $436-468$.

DeMeo, G.A., Laczniak, R.J., Boyd, R.A., Smith, J.L., and Nylund, W.E., 2003, Estimated ground-water discharge by evapotranspiration from Death Valley, California, 19972001: U.S. Geological Survey Water-Resources Investigations Report 03-4254, 27 p.

Enright, M., Wilberg, D.E., and Tibbetts, J.R., 2005, Water resources data, Utah, water year 2004: U.S. Geological Survey Water-Data Report UT-04-1, 428 p.

ERTEC, 1982, Assessment of environmental contamination exploratory stage, Tooele Army Depot, Tooele, Utah: Volumes I-IV, October 31, 1982.

Fenneman, N.M., 1931, Physiography of the Western United States: New York, McGraw-Hill, 534 p.

Flint, A.L., and Flint, L.E., 2007, Application of the basin characterization model to estimate in-place recharge and runoff potential in the Basin and Range carbonate-rock aquifer system, White Pine County, Nevada, and adjacent areas in Nevada and Utah: U.S. Geological Survey Scientific Investigations Report 2007-5009, 21 p.

Gates, J.S., 1963, Selected hydrologic data, Tooele Valley, Tooele County, Utah: U.S. Geological Survey Basic-Data Report no. 7, 23 p.

Gates, J.S., 1965, Re-evaluation of the ground-water resources of Tooele Valley, Utah: Utah State Engineer Technical Publication No. 12,68 p.

Harbaugh, A.W., Banta, E.R., Hill, M.C., and McDonald, M.G., 2000, MODFLOW-2000, the U.S. Geological Survey modular ground-water model - user guide to modularization concepts and the Ground-Water Flow Process: U.S. Geological Survey Open-File Report 00-92, 121 p. Available at http://water.usgs.gov/nrp/gwsoftware/modflow2000/ modflow2000.html.
Heilweil, V.M., Earle, J.D., Cederberg, J.R., Messer, M.M., Jorgensen, B.E., Verstraeten, I.M., Moura, M.A., Querido, A., Spencer, F., and Osorio, T., 2006, Evaluation of baseline ground-water conditions in the Mosteiros, Ribeira Paul, and Ribeira Faja Basins, Republic of Cape Verde, West Africa, 2005-06: U.S. Geological Survey Scientific Investigations Report 06-5207, 42 p.

Hill, M.C., Banta, E.R., Harbaugh, A.W., and Anderman, E.R., 2000, MODFLOW-2000, the U.S. Geological Survey modular ground-water model-user guide to the observation, sensitivity, and parameter-estimation processes and three post-processing programs: U.S. Geological Survey Open-File Report 00-184, 209 p.

Hood, J.W., Price, D., and Waddell, K.M., 1969, Hydrologic reconnaissance of Rush Valley, Tooele County, Utah: Utah Department of Natural Resources Technical Publication no. 23,63 p.

James M. Montgomery Consulting Engineers, Inc., 1988, Ground-water quality assessment engineering report for Tooele Army Depot, Utah: Salt Lake City, Utah.

Kenney, T.A., Wright, S.J., and Stolp, B.J., 2006, Groundwater movement and water quality in Lake Point, Tooele County, Utah, 1999-2003: U.S. Geological Survey Scientific Investigations Report 06-5124, 21 p.

Kleinfelder Inc., 2000, Northeast boundary investigations source determination document, Tooele Army Depot, Tooele, Utah: Salt Lake City, Utah.

Kleinfelder Inc., 2003, Semi-annual groundwater quality report and voluntary SWMU sampling, spring 2003, Tooele Army Depot, Tooele, Utah: Salt Lake City, Utah.

Lambert, P.M., 1995, Numerical simulation of ground-water flow in basin-fill material in Salt Lake Valley, Utah: Utah Department on Natural Resources Technical Publication no. 110-B, 58 p.

Lambert, P.M., and Stolp, B.J., 1999, Hydrology and simulation of the ground-water flow system in Tooele Valley, Utah: U.S. Geological Survey Water-Resources Investigations Report 99-4014, 60 p.

Lowe, M., Wallace, J., Butler, M., Riding, R., and Johnson, A., 2004, Ground-water sensitivity and vulnerability to pesticides, Tooele Valley, Tooele County, Utah: Utah Geological Survey Miscellaneous Publication 04-3, 23 p.

Maurer, D.K., Berger, D.L., Tumbusch, M.L., and Johnson, M.J., 2005, Rates of evapotranspiration, recharge from precipitation beneath selected areas of native vegetation, and streamflow gain and loss in Carson Valley, Douglas County, Nevada, and Alpine County, California: U.S. Geological Survey Scientific Investigations Report 05-5288, 70 p. 
Mazor, E., 1991, Applied chemical and isotopic groundwater hydrology: New York, Halsted Press, 274 p.

McDonald, M.G., and Harbaugh, A.W., 1988, A modular three-dimensional finite-difference ground-water flow model: U.S. Geological Survey Techniques of WaterResources Investigations, book 6, chap. A1, variously paged.

Michel, R.L., 1989, Tritium deposition over the continental United States, 1953-1983, in Atmospheric Deposition: Oxfordshire, United Kingdom, International Association of Hydrological Sciences, p. 109-115.

Moore, W.J., and Sorensen, M.L., 1979, Geologic map of the Tooele $1 \times 2$ degree quadrangle, Utah: U.S. Geological Survey Miscellaneous Investigations Series Map I-1132.

National Elevation Dataset, 2004, Digital elevation model data: accessed in 2004 at http://seamless.usgs.gov/ viewer. htm.

National Solar Radiation Database, 2007, Solar radiation data for flat-plate and concentrating collectors: accessed on May 2, 2007, at http://rredc.nrel.gov/solar/old_data/nsrdb/19611990/redbook/sum2/.

Nichols, W.D., 2000, Chapter A. Determining ground-water evapotranspiration from phreatophyte shrubs and grasses as a function of plant cover or depth to ground water, Great Basin, Nevada and eastern California, in Regional groundwater evapotranspiration and ground-water budgets, Great Basin, Nevada: U.S. Geological Survey Professional Paper 1628, p. A1-A14.

Oroud, I.M., 1995, Effects of salinity upon evaporation from pans and shallow lakes near the Dead Sea: Theoretical and Applied Climatology, v. 52, p. 231-240.

Pollock, D.W., 1994, User's guide to MODPATH/MODPATHPLOT, Version 3: a particle tracking post-processing package for MODFLOW, the U.S. Geological Survey finite-difference ground-water flow model: U.S. Geological Survey Open-File Report 94-464, variously paged.

Prudic, D.E., 1989, Documentation of a computer program to simulate stream-aquifer relations using a modular, finite-difference, ground-water flow model: U.S. Geological Survey Open-File Report 88-729, 113 p.

Razem, A.C., and Steiger, J.I., 1981, Ground-water conditions in Tooele Valley, Utah, 1976-78: Utah Department of Natural Resources Technical Publication No. 69, 95 p.

SWCA Environmental Consultants, 2006, Tooele Valley wetlands special area management plan, draft document: Salt Lake City, Utah, 71 p.
Solomon, D.K., and Cook, P.G., 2000, ${ }^{3} \mathrm{H}$ and ${ }^{3} \mathrm{He}$, in Cook, P.G., and Herczeg, A.L., eds., Environmental tracers in subsurface hydrology: Boston, Kluwer Academic Publishers, p. $397-424$.

Steiger, J.I., and Lowe, M., 1997, Recharge and discharge areas and quality of ground water in Tooele Valley, Tooele County, Utah: U.S. Geological Water-Resources Investigations Report 97-4005, 4 sheets.

Stolp, B.J., 1994, Hydrology and potential for ground-water development in southeastern Tooele Valley and adjacent areas in the Oquirrh Mountains, Tooele County, Utah: Utah Department of Natural Resources Technical Publication no. 107, 67 p.

Susong, D.D., 1997, Chemical quality of water in the consolidated rock and the basin-fill aquifer, west side of the Oquirrh Mountains, Tooele County, Utah: U.S. Geological Survey Water-Resources Investigations Report 97-4247, 2 p.

Susong, D.D., 2005, Ground-water movement and nitrate in ground water, east Erda area, Tooele County, Utah, 1997-2000: U.S. Geological Survey Scientific Investigations Report 05-5096, 4 sheets and 2 tables.

Thiros, S.A., and Manning, A.H., 2004, Quality and sources of ground water used for public supply in Salt Lake Valley, Salt Lake County, Utah, 2001: U.S. Geological Survey WaterResources Investigations Report 03-4325, 95 p.

Thomas, H.E., 1946, Ground water in Tooele County, Tooele County, Utah: Utah State Engineer Technical Publication no. 4, in Utah State Engineer 25th Biennial Report, p. 91-238.

Tibbetts, J.R., Enright, M., and Wilberg, D.E., 2003, Water resources data, Utah, water year 2003: U.S. Geological Survey Water-Data Report UT-03-1, 390 p.

Tooker, E.W., 1980, Preliminary geologic map of the Tooele quadrangle (7 1/2 minute), Tooele County, Utah: U.S. Geological Survey Open-File Report 80-623.

TriTechnics Corporation, 1996, Oquirrh Mountains ground water model - Bingham Canyon mine and facility, for Kennecott Corporation: Salt Lake City, Utah, 32 p.

U.S. Army Corps of Engineers, 2005, USACE.net private database accessed on September 12, 2005, at http://usace. net/.

U.S. Army Corps of Engineers, 2004, Tooele Army Depot groundwater flow and contaminant transport model (2004): Davis, California, U.S. Army Corps of Engineers, Hydrologic Engineering, 94 p.

U.S. Army Corps of Engineers, 2006, Tooele Army Depot groundwater flow and contaminant transport model (2006): Davis, California, U.S. Army Corps of Engineers, Hydrologic Engineering Center, 94 p. 
U.S. Army Corps of Engineers, 2007, Tooele Army Depot groundwater flow and contaminant transport model (2007): Davis, California, U.S. Army Corps of Engineers, Hydrologic Engineering, $90 \mathrm{p}$.

Utah Department of Environmental Quality, Division of Water Quality, 2005, Monitoring and water quality, drinking water standards: Salt Lake City, Utah, Utah Administrative Code Rule R309-200, 16 p.

Utah Department of Natural Resources, Division of Water Rights, 2006, accessed on February 21, 2006, at http://www. water rights.utah.gov/techinfo/consumpt/i8771.htm.

Wallace, J., 1999, Petition for ground-water-quality classification, Tooele Valley, Tooele County, Utah: Salt Lake City, Utah, unpublished Utah Geological Survey petition to Utah Water Quality Board, 16 p.

Wallace, J., and Lowe, M., 1998, The potential impact of septic tank soil-absorption systems on water quality in the principal valley-fill aquifer, Tooele Valley, Tooele County, Utah-assessment and guidelines: Utah Geological Survey Report of Investigation 235, $10 \mathrm{p}$.

Wilde, F.D., and Radtke, D.B., 1998, National field manual for the collection of water-quality data, field measurements: U.S. Geological Survey Techniques of Water-Resources Investigations, book 9, chap. A6, 233 p. 


\section{Appendix A-Water-Quality Methods}

\section{Introduction}

This appendix offers a brief summary of the techniques, methods, and theory involved with the collection and interpretations of the water-quality data presented in this report. Portions of this text are based on the "Sources of Ground-Water Recharge" section of Thiros and Manning (2004), the "Isotope Chemistry" section of Brooks and Mason (2005), and the "Methods" section of Heilweil and others (2006).

Field water-quality parameters measured during water-sample collection include specific conductance, $\mathrm{pH}$, temperature, dissolved oxygen, and barometric and total dissolved-gas pressure. These parameters were measured using a calibrated multimeter probe following U.S. Geological Survey (USGS) protocol (Wilde and Radtke, 1998).

\section{Deuterium and 0xygen-18}

The stable isotopes of water $\left({ }^{2} \mathrm{H},{ }^{18} \mathrm{O}\right)$ can be used to evaluate sources and locations of recharge to a ground-water system (Mazor, 1991). These stable isotopes are analyzed by measuring the ratio of the heavier, less abundant isotope to the lighter, more abundant isotope and are reported as differences to a known standard. "Heavier" refers to the condition where there are additional neutrons in the nucleus of the hydrogen or oxygen atom, thereby increasing the mass or atomic weight of the water molecule. The isotope ratios are reported as delta $(\delta)$ values expressed as parts per thousand (permil). The $\delta$ value for an isotope $\mathrm{X}$, is determined by:

$$
\delta \mathrm{X}=\left(\mathrm{R}_{\text {sample }} / \mathrm{R}_{\text {standard }}-1\right) \times 1,000
$$

where

$$
\begin{gathered}
\delta \mathrm{X} \text { is the } \delta \text { value for the heavy isotope in the sample } \\
\left({ }^{2} \mathrm{H} \text { or }{ }^{18} \mathrm{O}\right) \text {, } \\
\mathrm{R}_{\text {sample }} \text { is the ratio of the heavy isotope to the light isotope } \\
\text { for a specific element in the sample, and } \\
\mathrm{R}_{\text {standard }} \text { is the ratio of the heavy isotope to the light isotope } \\
\text { for the same element in the standard reference } \\
\text { material. The standard reference material used } \\
\text { in this report is Vienna Standard Mean Ocean } \\
\text { Water (VSMOW). }
\end{gathered}
$$

A positive $\delta \mathrm{X}$ value indicates that the sample is enriched in the heavier isotope with respect to the standard. A negative $\delta \mathrm{X}$ value indicates that the sample is depleted in the heavier isotope with respect to the standard. In general, the isotopic composition of precipitation is controlled by temperature; precipitation falling at cooler temperatures (at higher altitude or as snow) is more depleted in ${ }^{2} \mathrm{H}$ and ${ }^{18} \mathrm{O}$ than precipitation at warmer temperatures (at lower altitudes or as rain). The relation between $\delta^{2} \mathrm{H}$ and $\delta^{18} \mathrm{O}$ in precipitation plots along a trend line known as the meteoric water line. Cooler precipitation plots lower on the trend line and warmer precipitation plots higher on the trend line. The trend line for worldwide precipitation defines the Global Meteoric Water Line (GMWL) and is described by the equation:

$$
\delta^{2} \mathrm{H}=8\left(\delta^{18} \mathrm{O}\right)+\mathrm{d}
$$

where

$$
\begin{aligned}
& d \quad \text { is the }{ }^{2} \mathrm{H} \text { excess (Dansgaard, 1964). The mean } \\
& \text { global value for } d \text { in freshwater is } 10 \text { (Craig, } \\
& \text { 1961). }
\end{aligned}
$$

Depending on conditions and sources of precipitation, isotopic data from specific areas may trend along a line that is above or below the GMWL. The trend can then be used to establish a precipitation trend or if there are adequate data, a Local Meteoric Water Line (LMWL). In addition to temperature, isotopic composition is also affected by evaporation (e.g. during irrigation or from open water). Evaporation creates enrichment in ${ }^{18} \mathrm{O}$ relative to ${ }^{2} \mathrm{H}$, which results in trends that plot below the meteoric water line and with a slope less than eight (an evaporation trend).

\section{Helium-3/Tritium}

Tritium $\left({ }^{3} \mathrm{H}\right)$ and helium-3 $\left({ }^{3} \mathrm{He}\right)$ can be used to determine apparent ground-water age. During the 1950s and 1960s, large amounts of ${ }^{3} \mathrm{H}$ were released into the atmosphere and subsequently into the hydrologic cycle by above-ground thermonuclear weapons testing. As a result, ${ }^{3} \mathrm{H}$ concentrations in precipitation peaked during 1963-1964 at three orders of magnitude above natural concentrations (Michel, 1989). That peak can distinguish ground water recharged before or after the beginning of weapons testing (pre or post mid-1950s). Tritium is a radioactive isotope of hydrogen and decays to tritiogenic ${ }^{3} \mathrm{He}\left({ }^{3} \mathrm{He}_{\text {trit }}\right)$ with a half-life of $12.43 \mathrm{yr}$. Using the combination of both ${ }^{3} \mathrm{H}$ and ${ }^{3} \mathrm{He}_{\text {trit }}$, the recharge period can be refined from pre or post mid-1950s to an apparent recharge year.

The difficulty with ${ }^{3} \mathrm{He} /{ }^{3} \mathrm{H}$ age dating is isolating ${ }^{3} \mathrm{He}_{\text {trit }}$ (the daughter product) from the total measured ${ }^{3} \mathrm{He}\left({ }^{3} \mathrm{He}_{\mathrm{m}}\right)$. In addition to ${ }^{3} \mathrm{He}_{\text {trit }}$, the measured amount includes ${ }^{3} \mathrm{He}$ derived from solubility equilibrium with the atmosphere $\left({ }^{3} \mathrm{He}_{\text {sol }}\right)$, entrainment of excess air in the unsaturated zone ${ }^{3} \mathrm{He}_{\mathrm{e}}$, and terrigenic sources [i.e. nuclear reactions in the crust and the 


\section{A-2 Hydrology and Simulation of Ground-Water Flow in the Tooele Valley Ground-Water Basin, Tooele County, Utah}

mantle $\left.\left({ }^{3} \mathrm{He}_{\text {terr }}\right)\right]$. For most ground water, terrigenic sources of ${ }^{3} \mathrm{He}$ are minimal (D.K. Solomon, University of Utah, Dept. of Geology, written commun., 2003). Knowing the potential sources of ${ }^{3} \mathrm{He}$, the amount of daughter product $\left({ }^{3} \mathrm{He}_{\text {trit }}\right)$ is determined as a residual:

$$
{ }^{3} \mathrm{He}_{\text {trit }}={ }^{3} \mathrm{He}_{\mathrm{m}}-{ }^{3} \mathrm{He}_{\mathrm{sol}}-{ }^{3} \mathrm{He}_{\mathrm{e}}-{ }^{3} \mathrm{He}_{\text {terr }}
$$

To compute quantities for each of the sources, measured values of helium-4 $\left({ }^{4} \mathrm{He}_{\mathrm{m}}\right)$, and neon-20 $\left({ }^{20} \mathrm{Ne}_{\mathrm{m}}\right)$ are used. First, the equilibrium solubility of ${ }^{4} \mathrm{He}$ with the atmosphere $\left({ }^{4} \mathrm{He}_{\mathrm{sol}}\right)$ is calculated using Henry's law (with a Henry's law constant adjusted for air pressure, water temperature, and salinity). A "safe" estimate for temperature, pressure, and salinity are the conditions at the sample location. A better estimate would be conditions at the recharge location (i.e. recharge temperature, altitude, and salinity). Once ${ }^{4} \mathrm{He}_{\text {sol }}$ is estimated, ${ }^{3} \mathrm{He}_{\text {sol }}$ is calculated using the atmospheric ratio $\left(\mathrm{R}_{\mathrm{a}}\right)$ of ${ }^{3} \mathrm{He} /{ }^{4} \mathrm{He}\left({ }^{3} \mathrm{He}_{\mathrm{sol}}=\right.$ $\left.{ }^{4} \mathrm{He}_{\mathrm{sol}} * 1.384 \times 10^{-6}\right)$.

The most common source of excess air (dissolved gas in excess of solubility equilibrium) is air bubbles in the interstitial pore space of the unsaturated zone. Estimates of excess air are made using ${ }^{20} \mathrm{Ne}_{\mathrm{m}}$ and the same residual method as described in equation A3. ${ }^{20} \mathrm{Ne}$ due to equilibrium solubility $\left({ }^{20} \mathrm{Ne}_{\text {sol }}\right)$ is subtracted from ${ }^{20} \mathrm{Ne}_{\mathrm{m}}$ to get ${ }^{20} \mathrm{Ne}$ due to excess air $\left({ }^{20} \mathrm{Ne}_{\mathrm{e}}\right) \cdot{ }^{4} \mathrm{He}_{\mathrm{e}}$ is calculated using the atmospheric ratio of ${ }^{4} \mathrm{He} /{ }^{20} \mathrm{Ne}\left({ }^{4} \mathrm{He}_{\mathrm{e}}={ }^{20} \mathrm{Ne}_{\mathrm{e}} * 0.286\right)$. This is possible because the only known source of ${ }^{20} \mathrm{Ne}$ is the atmosphere. Once ${ }^{4} \mathrm{He}_{\mathrm{e}}$ is determined, ${ }^{3} \mathrm{He}_{\mathrm{e}}$ is calculated using the atmospheric ${ }^{3} \mathrm{He} /{ }^{4} \mathrm{He}$ ratio. The Closed Equilibrium Model (CE) (Aeschbach-Hertig and others, 2000), which was used in this report to interpret ${ }^{3} \mathrm{H} /{ }^{3} \mathrm{He}$ apparent age, is a more complex (and realistic) method to quantify ${ }^{3} \mathrm{He}_{\mathrm{e}}$ (and other noble gases) in water. CE accounts for incomplete dissolving (and fractionation) of the interstitial bubbles that are the source of excess air.

The most difficult source to quantify is ${ }^{3} \mathrm{He}_{\text {terr }}$. As with solubility equilibrium, the amount of ${ }^{3} \mathrm{He}_{\text {terr }}$ is estimated by first determining the amount of ${ }^{4} \mathrm{He}_{\text {terr }}$ and then applying a terrigenic ${ }^{3} \mathrm{He} /{ }^{4} \mathrm{He}$ ratio to derive ${ }^{3} \mathrm{He}_{\text {terr }}$. The difficulty comes from the fact that the ${ }^{3} \mathrm{He} /{ }^{4} \mathrm{He}$ ratio of terrigenic sources is variable. The ratio for He derived from the crust is on the order of $0.02 \mathrm{R}_{\mathrm{a}}$; for He derived from the mantle the average ratio is $8 \mathrm{R}_{\mathrm{a}}$. The crustal ratio is small enough $(0.02 * 1.384$ $\mathrm{x} 10^{-6}$ ) that a sample must contain relatively large amounts of crustal $\mathrm{He}$ for ${ }^{3} \mathrm{He}_{\text {terr }}$ to have any effect on the estimation of ${ }^{3} \mathrm{He}_{\text {trit }}$. However, if crustal He is elevated, or if there is mantle $\mathrm{He}$ in the sample, then the exact value of the ratio (e.g. 0.01, or 0.02 , or 0.03 , or 7 , or 8 , or 9 ) starts to significantly affect the ${ }^{3} \mathrm{He}_{\text {terr }}$ estimate and thereby ${ }^{3} \mathrm{He}_{\text {trit }}$. In general, if samples contain more than $5.0 \times 10^{-8} \mathrm{~cm}^{3} \mathrm{STP} / \mathrm{g}$ of ${ }^{4} \mathrm{He}_{\text {terr }}$ (which is determined as ${ }^{4} \mathrm{He}_{\mathrm{m}}-{ }^{4} \mathrm{He}_{\text {sol }}-{ }^{4} \mathrm{He}_{\mathrm{e}}$ ) a reliable estimate of ${ }^{3} \mathrm{He}_{\text {trit }}$ cannot be made. An initial evaluation of terrigenic sources can be done using the $\mathrm{R} / \mathrm{R}_{\mathrm{a}}$ ratio $\left(\mathrm{R}={ }^{3} \mathrm{He}_{\mathrm{m}}{ }^{4} \mathrm{He}_{\mathrm{m}}\right)$. When $\mathrm{R} / \mathrm{R}_{\mathrm{a}}$ is approximately 1.0, then the measured He concentrations are near the atmospheric ratio and all He is likely due to solubility equilibrium and excess air. If there is considerable crustal $\mathrm{He}, \mathrm{R} / \mathrm{R}_{\mathrm{a}}$ will be less than 1.0. If the terrigenic source is the mantle, $\mathrm{R} / \mathrm{R}_{\mathrm{a}}$ will be greater than 1.0. Water containing more than $5.0 \times 10^{-8} \mathrm{~cm}^{3} \mathrm{STP} / \mathrm{g}$ of ${ }^{4} \mathrm{He}_{\text {terr }}$ was classified as "premodern" (Manning, 2002, appendix B), and was not assigned an apparent age.

If a reliable estimate of ${ }^{3} \mathrm{He}_{\text {trit }}$ is possible, an apparent age for a sample is determined by the following equation (Solomon and Cook, 2000, p. 411):

$$
\mathrm{t}=\lambda^{-1} \ln \left({ }^{3} \mathrm{He}_{\text {trit }} /{ }^{3} \mathrm{H}+1\right)
$$

where

$\mathrm{t}$ is the apparent age in years, and

$\lambda \quad$ is the decay constant for ${ }^{3} \mathrm{H}$. 


\section{Appendix B-Scoping Model for Evaluation of Ground-Water Withdrawals at the Carr Fork Service Shaft}

\section{Introduction}

Mining activities in the Oquirrh Mountains includes one of the largest open-pit copper mines in the world, hundreds of miles of underground workings, and several dewatering tunnels. These disturbances have almost certainly altered natural ground-water flow directions and boundaries. The overall effects are approximated in the numerical simulation of the Tooele Valley ground-water basin as a 700 acre-ft/yr decrease in recharge in the Pass and Pine Canyon areas (see "Numerical Simulation of Ground-Water Flow, Discharge Boundaries" section of this report).

This appendix presents the results of a scoping-level numerical simulation of one specific mining-associated ground-water disturbance. Ground water is withdrawn from the Carr Fork Service Shaft (fig. B1) and exported out of the Tooele Valley ground-water basin for various mining related activities. The service shaft is located on the west side of the Oquirrh Mountains, in Pine Canyon, within the ground-water basin. The service shaft was driven in 1971 to a depth of $3,845 \mathrm{ft}$ below land surface and is hydraulically connected to a three-dimensional maze of underground mine workings by means of two horizontal tunnels (B. Vinton, North American Exploration, written commun., 2006). More than 90 percent of the underground workings, as measured by linear feet, exist east of and outside the Tooele Valley ground-water basin; the natural ground-water basin boundary in the Oquirrh Mountains is estimated to coincide with the topographic divide.

Because of the existence of underground mine workings, ground-water withdrawal at the Carr Fork Service Shaft cannot be treated as simply pumping from a consolidatedrock well. Assuming that the hydraulic conductivity of the underground workings and horizontal connector tunnels are essentially infinite, the diameter of the Carr Fork Service Shaft is conceptualized to match the areal extent of the workings. This concept is substantiated by monitoring of the underground workings and the service shaft that shows water levels are nearly identical at both locations during both static and pumping conditions (B. Vinton, North American Exploration, oral commun., 2006). During initial withdrawals at the service shaft, the source of water is storage within the workings. Once the workings are de-watered, the consolidated-rock matrix between individual tunnels and adits becomes the source of water. The potentiometric driving force will be the difference between the water level within the underground workings, assumed to be equal to the water level in the service shaft, and the consolidated-rock matrix.

\section{Model Construction}

A scoping-level, ground-water flow model was constructed using MODFLOW-2000 (Harbaugh and others, 2000) to estimate effects of withdrawals at the Carr Fork Service Shaft on the Tooele Valley ground-water basin. The model domain incorporates areas east and west of the topographic divide of the Oquirrh Mountains (fig. B1). Where it represents areas west of the divide, the domain is coincident with the calibrated numerical model described in the "Numerical Simulation of Ground-Water Flow" section of this report. For that area, model parameters are set equal to values used in the calibrated model; wells (using 2003 withdrawals) and streams are simulated. The model simulates average precipitation from 1971 to 2000 . For hydraulic parameters representing areas east of the topographic divide, values were extrapolated from the calibrated model. Geometric parameters (top and bottom altitudes of individual model layers) were extended on the basis of topography. For east areas the scoping model does not simulate streams and groundwater withdrawals. The Constant-Head Boundary Package (Harbaugh and others, 2000, p. 78) was used to fix model heads along the western and eastern extents of the model domain. The western boundary was chosen to estimate the 4,600 ft water-level contour simulated by the calibrated model. The same technique was used for the eastern boundary, using the 5,000 ft water-level contour computed by the steady-state simulation of ground-water flow in Salt Lake Valley (Lambert, 1995, fig. 16).

\section{Results}

Initially, model parameters associated with the ConstantHead Boundary Package were adjusted slightly (within 5 percent of initial values) to ensure that the numerical simulation converged to a solution. Some adjustment of assigned model-layer altitudes for the portion of the domain simulating eastern areas was done for the same reasons of convergence. Once a solution was obtained, withdrawals at the Carr Fork Service Shaft were simulated by placing Drain Package boundaries (Harbaugh and others, 2000, p. 71) in model layer 3 at 4 cells that coincide with the spatial extent of the underground workings (fig. B2). Drain altitude was set at $5,200 \mathrm{ft}$, the approximate pumping water level of the service shaft (B. Vinton, North American Exploration, oral commun., 2006). Drain conductance was adjusted so that simulated flow out of the drains was approximately 2,000 acre-ft/yr, the reported withdrawal from the Carr Fork Service Shaft for 2003 (Tibbetts and others, 2003; Enright and others, 2004). 


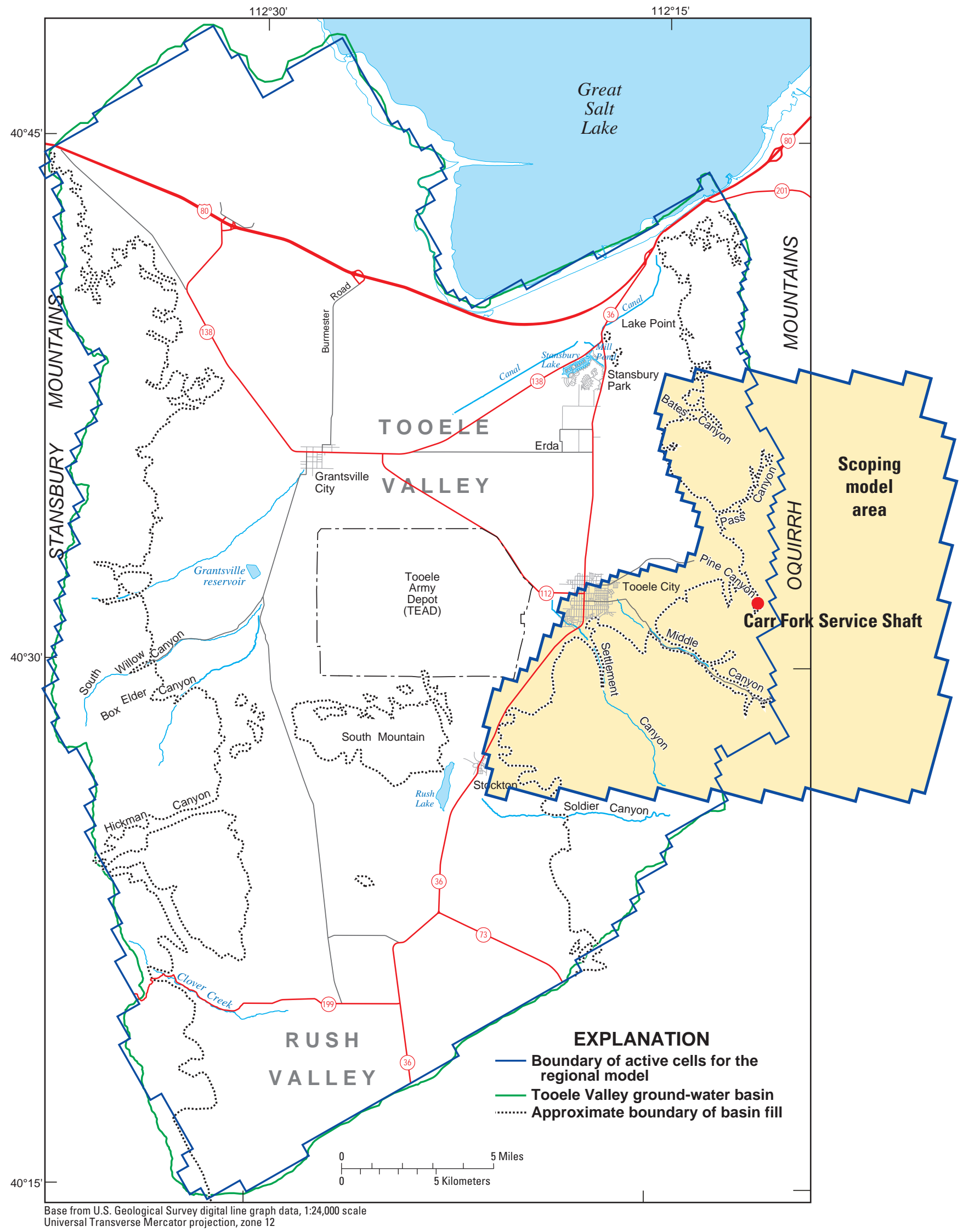

Figure B1. Tooele Valley ground-water basin numerical simulation and the scoping model used to examine dewatering at the Carr Fork Service Shaft, Tooele and Salt Lake Counties, Utah. 
The steady-state simulation of these conditions indicates that withdrawals at the Carr Fork Service Shaft result in about a 1,000 acre-ft/yr decrease in recharge to the Tooele Valley ground-water basin (50 percent of withdrawal at the Carr Fork Service Shaft). Decreased recharge in the calibrated numerical model is 700 acre- $\mathrm{ft} / \mathrm{yr}$ (see above). This discrepancy is not large enough to justify modification of the calibrated model.

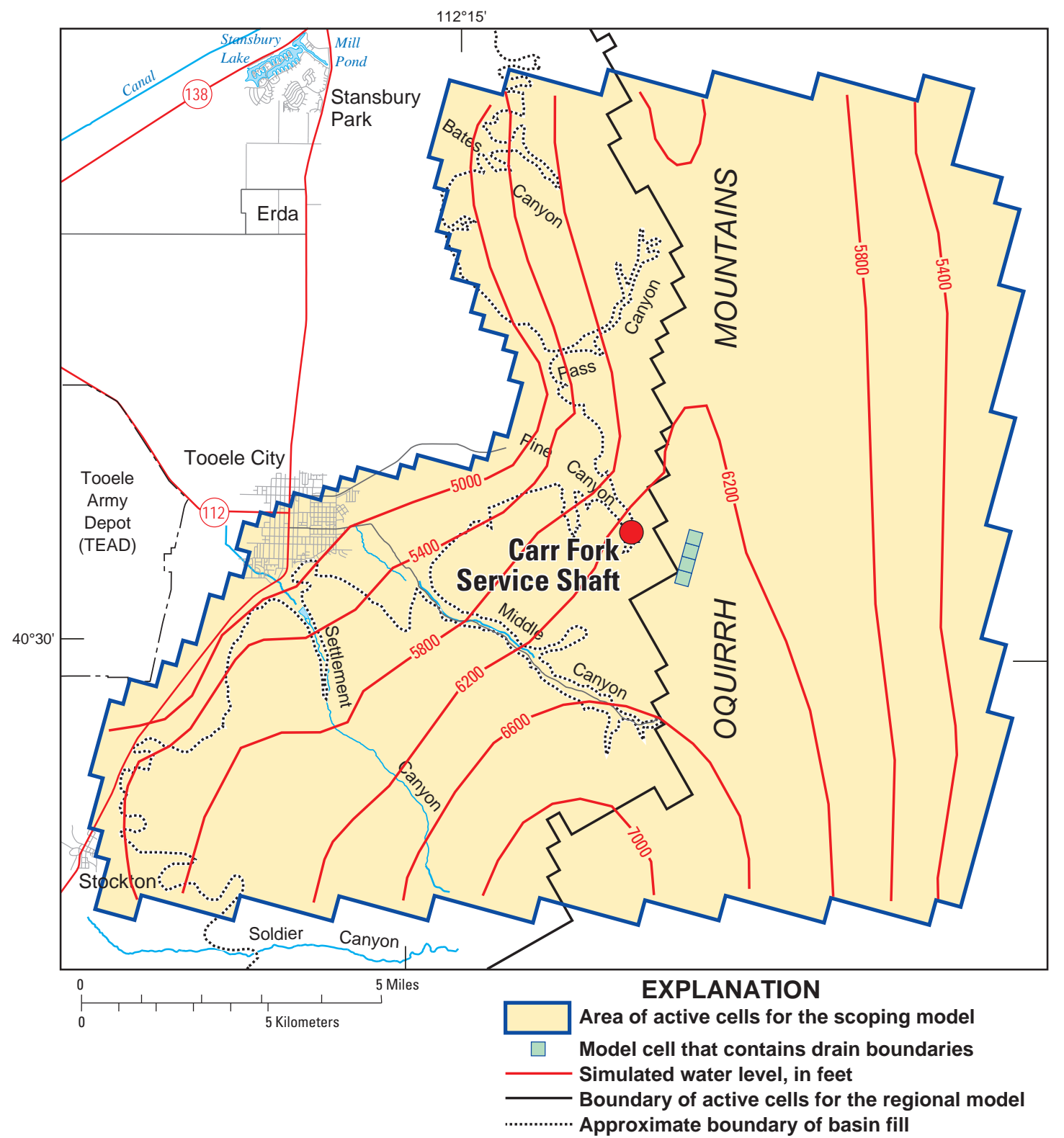

Figure B2. The location of drain boundaries and simulated steady-state water-level contours for dewatering activities at the Carr Fork Service Shaft, Tooele and Salt Lake Counties, Utah. 
B-4 Hydrology and Simulation of Ground-Water Flow in the Tooele Valley Ground-Water Basin, Tooele County, Utah 


\section{Appendix C-Data Tables}

Table C1. U.S. Geological Survey site identification number, local well number, and use of data for selected wells with water levels and water quality, Tooele Valley ground-water basin, Tooele County, Utah.

[Spring 2003 water-level altitude determined from water levels measured by the U.S. Geological Survey from March 12 to April 2, 2003. Water-quality samples collected by the U.S. Geological Survey from 2003 to 2006. Site identification number: A unique identification number assigned to each site in the USGS's Ground-Water Site Inventory system; Local well number, see figure 2 for explanation; B, wells used for aquifer interference tests; C, water-level contour map for spring 2003; G, dissolved-gas analysis; M, major ions, nutrients, and arsenic analysis; O, deuterium/oxygen-18 analysis; S, steady-state model calibration; T, transient model calibration; TR, tritium analysis; blank areas indicate that water-level or water-quality data were not available]

\begin{tabular}{|c|c|c|c|c|}
\hline $\begin{array}{c}\text { Site } \\
\text { identification } \\
\text { number }\end{array}$ & $\begin{array}{c}\text { Local } \\
\text { well number }\end{array}$ & $\begin{array}{l}\text { Water- } \\
\text { level } \\
\text { use }\end{array}$ & $\begin{array}{c}\text { Spring } 2003 \\
\text { water-level } \\
\text { altitude }\end{array}$ & $\begin{array}{l}\text { Water- } \\
\text { quality } \\
\text { use }\end{array}$ \\
\hline 404242112131101 & (C-1-3)30aad-1 & $\mathrm{C}, \mathrm{T}$ & ${ }^{1} 4,519$ & \\
\hline 404242112131102 & (C-1-3)30aad-2 & $\mathrm{T}$ & & M \\
\hline 404242112131103 & (C-1-3)30aad-3 & $\mathrm{C}, \mathrm{T}$ & ${ }^{14} 4,247$ & \\
\hline 404140112152401 & (C-1-4)35aad-1 & $\mathrm{C}, \mathrm{T}$ & 4,231 & \\
\hline 404127112153801 & $(\mathrm{C}-1-4) 35 \mathrm{dba}-1$ & $\mathrm{C}, \mathrm{T}$ & 4,251 & \\
\hline 404135112151901 & $(\mathrm{C}-1-4) 36 b b c-2$ & $\mathrm{C}, \mathrm{T}$ & 4,250 & \\
\hline 404137112151602 & (C-1-4)36bbd-2 & $\mathrm{T}$ & & \\
\hline 404120112151301 & (C-1-4)36cba-1 & $\mathrm{T}$ & & \\
\hline 404105112151501 & $(\mathrm{C}-1-4) 36 \mathrm{ccb}-1$ & $\mathrm{C}, \mathrm{T}$ & 4,251 & M,TR,G \\
\hline 404105112151502 & $(\mathrm{C}-1-4) 36 \mathrm{ccb}-2$ & $\mathrm{C}, \mathrm{T}$ & 4,252 & $\mathrm{M}, \mathrm{TR}, \mathrm{G}$ \\
\hline 404105112151503 & $(\mathrm{C}-1-4) 36 \mathrm{ccb}-3$ & $\mathrm{C}, \mathrm{T}$ & 4,251 & M,TR,G \\
\hline 403855112140901 & $(\mathrm{C}-2-3) 18 \mathrm{bcc}-1$ & $\mathrm{C}, \mathrm{T}$ & 5,010 & \\
\hline 404040112143301 & (C-2-4)1aca-1 & & & $\mathrm{M}, \mathrm{O}, \mathrm{TR}, \mathrm{G}$ \\
\hline 404045112151801 & $(\mathrm{C}-2-4) 1 \mathrm{bbc}-1$ & $\mathrm{C}, \mathrm{T}$ & 4,252 & M \\
\hline 404006112142601 & (C-2-4)1ddc-1 & $\mathrm{C}, \mathrm{T}$ & 4,415 & \\
\hline 404053112154801 & (C-2-4)2aba-1 & $\mathrm{S}, \mathrm{T}$ & & \\
\hline 404046112154801 & (C-2-4)2abd-1 & $\mathrm{C}, \mathrm{T}$ & 4,252 & \\
\hline 404054112155901 & $(\mathrm{C}-2-4) 2 \mathrm{baa}-3$ & $\mathrm{C}, \mathrm{T}$ & 4,250 & \\
\hline 404014112160601 & $(C-2-4) 2 c d b-1$ & $\mathrm{~T}$ & & \\
\hline 404011112160702 & $(\mathrm{C}-2-4) 2 \mathrm{cdb}-2$ & $\mathrm{C}, \mathrm{T}$ & 4,247 & \\
\hline 404027112154101 & $(\mathrm{C}-2-4) 2 \mathrm{dab}-1$ & $\mathrm{~T}$ & & \\
\hline 404023112154501 & $(\mathrm{C}-2-4) 2 \mathrm{dba}-1$ & $\mathrm{~T}$ & & \\
\hline 404007112154501 & $(C-2-4) 2 d c a-1$ & $\mathrm{~T}$ & & \\
\hline 404004112155801 & $(\mathrm{C}-2-4) 2 \mathrm{dcc}-2$ & $\mathrm{C}, \mathrm{T}$ & 4,248 & M \\
\hline 404007112154801 & (C-2-4)2dcd-1 & $\mathrm{C}, \mathrm{T}$ & 4,250 & \\
\hline 404013112152801 & (C-2-4)2dda-1 & $\mathrm{C}, \mathrm{T}$ & 4,253 & \\
\hline 404023112154001 & (C-2-4)2ddb-1 & $\mathrm{T}$ & & \\
\hline 404022112154402 & $(\mathrm{C}-2-4) 2 \mathrm{ddc}-2$ & $\mathrm{~T}$ & & \\
\hline 403912112193701 & $(\mathrm{C}-2-4) 8 \mathrm{cdc}-1$ & $\mathrm{~S}, \mathrm{~T}$ & & \\
\hline 403918112172201 & (C-2-4)9cda-1 & $\mathrm{S}, \mathrm{T}$ & & \\
\hline 404001112163800 & (C-2-4)10aaa-1 & $\mathrm{T}$ & & \\
\hline 404000112163201 & (C-2-4)10aaa-2 & $\mathrm{C}, \mathrm{T}$ & 4,245 & \\
\hline 403950112163301 & (C-2-4)10aad-1 & $\mathrm{C}, \mathrm{T}$ & 4,246 & \\
\hline 403943112171101 & (C-2-4)10bda-1 & $\mathrm{C}, \mathrm{T}$ & 4,231 & \\
\hline 403943112171102 & $(\mathrm{C}-2-4) 10 \mathrm{bda}-2$ & $\mathrm{C}, \mathrm{T}$ & 4,231 & \\
\hline 403943112171103 & (C-2-4)10bda-3 & $\mathrm{C}, \mathrm{T}$ & 4,231 & \\
\hline 403917112171101 & $(\mathrm{C}-2-4) 10 \mathrm{cda}-1$ & $\mathrm{C}, \mathrm{T}$ & 4,247 & \\
\hline 400943112155801 & (C-2-4)11acb-1 & $\mathrm{C}, \mathrm{T}$ & 4,247 & \\
\hline 403937112155801 & $(\mathrm{C}-2-4) 11 \mathrm{acc}-1$ & $\mathrm{C}, \mathrm{T}$ & 4,248 & \\
\hline 403942112161501 & $(\mathrm{C}-2-4) 11 \mathrm{bdc}-1$ & $\mathrm{C}, \mathrm{T}$ & 4,247 & \\
\hline 403835112171801 & $(\mathrm{C}-2-4) 15 \mathrm{cac}-\mathrm{S} 1$ & & & M \\
\hline 403818112173401 & $(\mathrm{C}-2-4) 15 \mathrm{ccc}-1$ & $\mathrm{~S}, \mathrm{~T}$ & & \\
\hline 403828112181901 & $(C-2-4) 16 c d a$ & & & M \\
\hline 403835112180201 & (C-2-4)16dbd & & & M \\
\hline
\end{tabular}

\begin{tabular}{|c|c|c|c|c|}
\hline $\begin{array}{c}\text { Site } \\
\text { identification } \\
\text { number }\end{array}$ & $\begin{array}{c}\text { Local } \\
\text { well number }\end{array}$ & $\begin{array}{l}\text { Water- } \\
\text { level } \\
\text { use }\end{array}$ & $\begin{array}{c}\text { Spring } 2003 \\
\text { water-level } \\
\text { altitude }\end{array}$ & $\begin{array}{l}\text { Water- } \\
\text { quality } \\
\text { use }\end{array}$ \\
\hline 403826112180701 & $(C-2-4) 16 d c b-1$ & $\mathrm{~T}$ & & $\mathrm{M}, \mathrm{O}, \mathrm{TR}$ \\
\hline 403827112175601 & (C-2-4)16ddb & & & M \\
\hline 403818112191001 & $(\mathrm{C}-2-4) 17 \mathrm{ccb}-1$ & & & M \\
\hline 403831112185401 & (C-2-4)17dad-1 & & & M \\
\hline 403818112191201 & $(\mathrm{C}-2-4) 17 \mathrm{dcd}-1$ & $\mathrm{C}, \mathrm{S}, \mathrm{T}$ & 4,276 & \\
\hline 403749112203601 & (C-2-4)19bdd-1 & $\mathrm{S}, \mathrm{T}$ & & M \\
\hline 403743112202401 & $(\mathrm{C}-2-4) 19 \mathrm{dbb}-1$ & & & M \\
\hline 403725112190001 & $(\mathrm{C}-2-4) 20 \mathrm{ddc}-1$ & $\mathrm{~S}, \mathrm{~T}$ & & \\
\hline 403811112180601 & $(\mathrm{C}-2-4) 21 \mathrm{abb}$ & & & M \\
\hline 403756112181601 & $(\mathrm{C}-2-4) 21 \mathrm{acc}$ & & & M \\
\hline 403752112173601 & (C-2-4)21add-1 & $\mathrm{S}, \mathrm{T}$ & & M \\
\hline 403725112183201 & $(\mathrm{C}-2-4) 21 \mathrm{cdc}-1$ & & & M \\
\hline 403738112175501 & $(\mathrm{C}-2-4) 21 \mathrm{ddb}-1$ & $\mathrm{~T}$ & & $\mathrm{M}, \mathrm{O}, \mathrm{TR}$ \\
\hline 403808112171501 & $(\mathrm{C}-2-4) 22 \mathrm{bac}-1$ & $\mathrm{~T}$ & & \\
\hline 403735112172501 & $(C-2-4) 22$ cca-3 & $\mathrm{T}$ & & \\
\hline 403727112163301 & $(\mathrm{C}-2-4) 22 \mathrm{ddd}-1$ & $\mathrm{C}, \mathrm{T}$ & 4,378 & M,TR,G \\
\hline 403727112163302 & $(\mathrm{C}-2-4) 22 \mathrm{ddd}-2$ & $\mathrm{C}, \mathrm{T}$ & 4,377 & $\mathrm{M}, \mathrm{TR}, \mathrm{G}$ \\
\hline 403727112163303 & $(\mathrm{C}-2-4) 22 \mathrm{ddd}-3$ & $\mathrm{C}, \mathrm{T}$ & 4,377 & $\mathrm{M}, \mathrm{TR}, \mathrm{G}$ \\
\hline 403754112162701 & $(\mathrm{C}-2-4) 23 \mathrm{cbb}-1$ & $\mathrm{~T}$ & & \\
\hline 403738112162601 & $(\mathrm{C}-2-4) 23 \mathrm{ccb}-1$ & $\mathrm{C}, \mathrm{T}$ & 4,373 & \\
\hline 403733112162501 & $(\mathrm{C}-2-4) 23 \mathrm{ccb}-2$ & $\mathrm{C}, \mathrm{T}$ & 4,373 & \\
\hline 403728112162801 & $(\mathrm{C}-2-4) 23 \mathrm{ccc}-1$ & $\mathrm{~T}$ & & \\
\hline 403725112161001 & $(C-2-4) 26 b a b-2$ & $\mathrm{C}, \mathrm{T}$ & 4,375 & \\
\hline 403714112161001 & (C-2-4)26bac-2 & $\mathrm{C}, \mathrm{T}$ & 4,375 & \\
\hline 403710112162801 & $(\mathrm{C}-2-4) 26 \mathrm{bcb}-2$ & $\mathrm{C}, \mathrm{T}$ & 4,375 & \\
\hline 403703112161501 & $(\mathrm{C}-2-4) 26 \mathrm{bcd}-1$ & $\mathrm{C}, \mathrm{T}$ & 4,377 & \\
\hline 403705112162101 & $(C-2-4) 26 b c d-3$ & $\mathrm{~T}$ & & \\
\hline 403702112161101 & $(\mathrm{C}-2-4) 26 \mathrm{bdc}-2$ & $\mathrm{C}, \mathrm{T}$ & 4,376 & \\
\hline 403706112160201 & (C-2-4)26bdd-2 & $\mathrm{T}$ & & \\
\hline 403702112155801 & (C-2-4)26caa-1 & $\mathrm{C}, \mathrm{T}$ & 4,376 & \\
\hline 403700112160201 & $(\mathrm{C}-2-4) 26 \mathrm{caa}-2$ & $\mathrm{C}, \mathrm{T}$ & 4,377 & \\
\hline 403648112162701 & $(\mathrm{C}-2-4) 26 \mathrm{cbc}-2$ & $\mathrm{C}, \mathrm{T}$ & 4,377 & \\
\hline 403635112161201 & $(\mathrm{C}-2-4) 26 \mathrm{ccd}-2$ & $\mathrm{~T}$ & & \\
\hline 403635112160301 & $(\mathrm{C}-2-4) 26 \mathrm{cdd}-1$ & $\mathrm{C}, \mathrm{T}$ & 4,379 & \\
\hline 403636112152401 & (C-2-4)26ddd-S1 & & & $\mathrm{M}, \mathrm{O}, \mathrm{TR}, \mathrm{G}$ \\
\hline 403724112163201 & $(\mathrm{C}-2-4) 27$ aaa-1 & $\mathrm{C}, \mathrm{T}$ & 4,374 & \\
\hline 403725112164601 & $(C-2-4) 27 a a b-1$ & $\mathrm{~T}$ & & \\
\hline 403714112163201 & $(\mathrm{C}-2-4) 27 \mathrm{aad}-2$ & $\mathrm{C}, \mathrm{T}$ & 4,373 & \\
\hline 403723112165601 & $(C-2-4) 27 a b a-2$ & $\mathrm{C}, \mathrm{T}$ & 4,372 & \\
\hline 403709112173201 & $(\mathrm{C}-2-4) 27 \mathrm{bcb}-1$ & & & M \\
\hline 403634112171501 & $(\mathrm{C}-2-4) 27 \mathrm{cdc}-1$ & $\mathrm{C}, \mathrm{T}$ & 4,377 & \\
\hline 403716112174801 & $(\mathrm{C}-2-4) 28 \mathrm{aac}-1$ & $\mathrm{C}, \mathrm{S}, \mathrm{T}$ & 4,279 & \\
\hline 403702112175601 & (C-2-4)28acd-3 & $\mathrm{S}, \mathrm{T}$ & & \\
\hline 403657112183801 & $(\mathrm{C}-2-4) 28 \mathrm{cbb}-1$ & & & $\mathrm{M}$ \\
\hline
\end{tabular}




\section{C-2 Hydrology and Simulation of Ground-Water Flow in the Tooele Valley Ground-Water Basin, Tooele County, Utah}

Table C1. U.S. Geological Survey site identification number, local well number, and use of data for selected wells with water levels and water quality, Tooele Valley ground-water basin, Tooele County, Utah.-Continued

[Spring 2003 water-level altitude determined from water levels measured by the U.S. Geological Survey from March 12 to April 2, 2003. Water-quality samples collected by the U.S. Geological Survey from 2003 to 2006. Site identification number: A unique identification number assigned to each site in the USGS's Ground-Water Site Inventory system; Local well number, see figure 2 for explanation; B, wells used for aquifer interference tests; C, water-level contour map for spring 2003; G, dissolved-gas analysis; M, major ions, nutrients, and arsenic analysis; O, deuterium/oxygen-18 analysis; S, steady-state model calibration; T, transient model calibration; TR, tritium analysis; blank areas indicate that water-level or water-quality data were not available]

\begin{tabular}{|c|c|c|c|c|}
\hline $\begin{array}{c}\text { Site } \\
\text { identification } \\
\text { number }\end{array}$ & $\begin{array}{c}\text { Local } \\
\text { well number }\end{array}$ & $\begin{array}{l}\text { Water- } \\
\text { level } \\
\text { use }\end{array}$ & $\begin{array}{l}\text { Spring } 2003 \\
\text { water-level } \\
\text { altitude }\end{array}$ & $\begin{array}{l}\text { Water- } \\
\text { quality } \\
\text { use }\end{array}$ \\
\hline 403647112175701 & (C-2-4)28dbd-5 & $\mathrm{C}, \mathrm{S}, \mathrm{T}$ & 4,363 & \\
\hline 403722112185201 & (C-2-4)29aaa-1 & & & M \\
\hline 403648112185001 & (C-2-4)29adc-1 & $\mathrm{C}, \mathrm{T}$ & 4,321 & \\
\hline 403658112185701 & $(\mathrm{C}-2-4) 29 \mathrm{adc}-2$ & & & M \\
\hline 403701112195001 & $(\mathrm{C}-2-4) 29 \mathrm{bcc}-1$ & $\mathrm{C}, \mathrm{S}, \mathrm{T}$ & 4,305 & M \\
\hline 403659112192601 & (C-2-4)29bdd-1 & & & M \\
\hline 403632112194201 & (C-2-4)29ccd-1 & $\mathrm{T}$ & & \\
\hline 403633112205001 & $(\mathrm{C}-2-4) 30 \mathrm{ccd}-1$ & & & M \\
\hline 403620112210001 & (C-2-4)30cdd-1 & & & M \\
\hline 403613112200101 & (C-2-4)31ada-1 & $\mathrm{C}, \mathrm{S}, \mathrm{T}$ & 4,359 & \\
\hline 403606112195401 & (C-2-4)31 add-6 & & & $\mathrm{M}, \mathrm{O}, \mathrm{TR}, \mathrm{G}$ \\
\hline 403613112210101 & $(\mathrm{C}-2-4) 31 \mathrm{bcb}-1$ & $\mathrm{~S}, \mathrm{~T}$ & & \\
\hline 403607112203301 & (C-2-4)31bdd-2 & $\mathrm{T}$ & & \\
\hline 403537112203101 & $(\mathrm{C}-2-4) 31 \mathrm{dbc}-1$ & $\mathrm{~S}, \mathrm{~T}$ & & \\
\hline 40361911218590 & $(\mathrm{C}-2-4) 32 \mathrm{aac}-1$ & & & M \\
\hline 403621112184901 & (C-2-4)32aad-1 & & & M \\
\hline 403602112194801 & $(\mathrm{C}-2-4) 32 \mathrm{cbb}-1$ & $\mathrm{~S}, \mathrm{~T}$ & & \\
\hline 403627112174701 & $(\mathrm{C}-2-4) 33 \mathrm{aab}-1$ & $\mathrm{~S}, \mathrm{~T}$ & & \\
\hline 403628112174701 & (C-2-4)33aac-1 & $\mathrm{S}, \mathrm{T}$ & & \\
\hline 403608112174301 & (C-2-4)33add-1 & $\mathrm{S}, \mathrm{T}$ & & \\
\hline 403617112184001 & $(C-2-4) 33 b c b-1$ & $\mathrm{~S}, \mathrm{~T}$ & & \\
\hline 403617112184201 & $(C-2-4) 33 b c b-5$ & $\mathrm{~T}$ & & \\
\hline 403556112174601 & $(C-2-4) 33$ dac-1 & $\mathrm{C}, \mathrm{T}$ & 4,376 & \\
\hline 403609112164201 & (C-2-4)34acd-1 & $\mathrm{C}, \mathrm{T}$ & 4,378 & \\
\hline 403609112170301 & (C-2-4)34bdd-1 & $\mathrm{T}$ & & \\
\hline 403632112153601 & $(C-2-4) 35 a a b-1$ & $\mathrm{C}, \mathrm{T}$ & 4,381 & \\
\hline 403631112154401 & $(\mathrm{C}-2-4) 35 \mathrm{aba}-1$ & $\mathrm{C}, \mathrm{T}$ & 4,378 & \\
\hline 403627112153901 & $(\mathrm{C}-2-4) 35 \mathrm{abd}-2$ & $\mathrm{C}, \mathrm{T}$ & 4,381 & \\
\hline 403620112152501 & (C-2-4)35ada-1 & $\mathrm{T}$ & & \\
\hline 403556112155601 & $(\mathrm{C}-2-4) 35 \mathrm{cad}-1$ & & & $\mathrm{O}$ \\
\hline 403556112160001 & $(\mathrm{C}-2-4) 35 \mathrm{cad}-2$ & $\mathrm{C}, \mathrm{T}$ & 4,379 & \\
\hline 403605112161701 & (C-2-4)35cba-2 & $\mathrm{C}, \mathrm{T}$ & 4,379 & \\
\hline 403559112162201 & $(\mathrm{C}-2-4) 35 \mathrm{cbc}-1$ & $\mathrm{~T}$ & & \\
\hline 403556112161201 & $(\mathrm{C}-2-4) 35 \mathrm{cbd}-1$ & & & $\mathrm{O}$ \\
\hline 403556112161601 & $(\mathrm{C}-2-4) 35 \mathrm{cbd}-2$ & $\mathrm{C}, \mathrm{T}$ & 4,380 & \\
\hline 403550112161701 & $(\mathrm{C}-2-4) 35 \mathrm{cca}-1$ & $\mathrm{C}, \mathrm{T}$ & 4,376 & \\
\hline 403547112161601 & $(\mathrm{C}-2-4) 35 \mathrm{ccd}-1$ & $\mathrm{C}, \mathrm{T}$ & 4,375 & \\
\hline 403600112154501 & $(\mathrm{C}-2-4) 35 \mathrm{dbd}-1$ & $\mathrm{C}, \mathrm{T}$ & 4,379 & \\
\hline 403556112154901 & $(\mathrm{C}-2-4) 35 \mathrm{dbc}-2$ & & & M \\
\hline 403547112155101 & $(\mathrm{C}-2-4) 35 \mathrm{dcc}-1$ & $\mathrm{C}, \mathrm{T}$ & 4,387 & $\mathrm{M}, \mathrm{O}, \mathrm{TR}$ \\
\hline 403547112155102 & $(\mathrm{C}-2-4) 35 \mathrm{dcc}-2$ & $\mathrm{C}, \mathrm{T}$ & 4,387 & $\mathrm{M}, \mathrm{O}, \mathrm{TR}, \mathrm{G}$ \\
\hline 403547112155103 & $(\mathrm{C}-2-4) 35 \mathrm{dcc}-3$ & $\mathrm{C}, \mathrm{T}$ & 4,387 & M,TR,G \\
\hline 404024112261801 & $(\mathrm{C}-2-5) 5 \mathrm{acc}-3$ & $\mathrm{C}, \mathrm{S}, \mathrm{T}$ & 4,212 & \\
\hline 403958112260401 & $(\mathrm{C}-2-5) 5 \mathrm{dcd}-4$ & $\mathrm{C}, \mathrm{S}, \mathrm{T}$ & 4,217 & \\
\hline 403956112264801 & (C-2-5)6ddd-7 & $\mathrm{S}, \mathrm{T}$ & & \\
\hline 403843112213701 & (C-2-5)13acc-1 & $\mathrm{C}, \mathrm{T}$ & 4,229 & \\
\hline 403846112262001 & (C-2-5)17bda-1 & $\mathrm{S}, \mathrm{T}$ & & \\
\hline 403840112274001 & (C-2-5)18bdc-1 & $\mathrm{S}, \mathrm{T}$ & & \\
\hline
\end{tabular}

\begin{tabular}{|c|c|c|c|c|}
\hline $\begin{array}{c}\text { Site } \\
\text { identification } \\
\text { number }\end{array}$ & $\begin{array}{c}\text { Local } \\
\text { well number }\end{array}$ & $\begin{array}{l}\text { Water- } \\
\text { level } \\
\text { use }\end{array}$ & $\begin{array}{c}\text { Spring } 2003 \\
\text { water-level } \\
\text { altitude }\end{array}$ & $\begin{array}{l}\text { Water- } \\
\text { quality } \\
\text { use }\end{array}$ \\
\hline 403813112272401 & $(\mathrm{C}-2-5) 18 \mathrm{dcc}-1$ & $\mathrm{C}, \mathrm{S}, \mathrm{T}$ & 4,230 & \\
\hline 403720112272401 & (C-2-5)19dcc-1 & $\mathrm{S}, \mathrm{T}$ & & \\
\hline 403748112261201 & $(\mathrm{C}-2-5) 20 \mathrm{acc}-1$ & $\mathrm{C}, \mathrm{S}, \mathrm{T}$ & 4,245 & M \\
\hline 403800112243601 & (C-2-5)21 aad-1 & & & M \\
\hline 403745112253701 & $(\mathrm{C}-2-5) 21 \mathrm{cbb}-1$ & $\mathrm{~S}, \mathrm{~T}$ & & \\
\hline 403736112230501 & $(\mathrm{C}-2-5) 23 \mathrm{cac}-1$ & $\mathrm{C}, \mathrm{S}, \mathrm{T}$ & 4,259 & \\
\hline 403722112211301 & $(C-2-5) 25 a a b-2$ & $\mathrm{~S}, \mathrm{~T}$ & & M \\
\hline 403632112214101 & (C-2-5)25cdd-4 & $\mathrm{C}, \mathrm{S}, \mathrm{T}$ & 4,322 & \\
\hline 403629112242701 & $(\mathrm{C}-2-5) 27 \mathrm{ccc}-1$ & $\mathrm{~S}, \mathrm{~T}$ & & \\
\hline 403655112255501 & $(\mathrm{C}-2-5) 29 \mathrm{adc}-2$ & $\mathrm{~S}, \mathrm{~T}$ & & \\
\hline 403654112275201 & $(\mathrm{C}-2-5) 30 \mathrm{bcc}-1$ & & & M \\
\hline 403643112274601 & $(\mathrm{C}-2-5) 30 \mathrm{cbd}-1$ & $\mathrm{C}, \mathrm{S}, \mathrm{T}$ & 4,263 & \\
\hline 403650112265001 & $(C-2-5) 30$ daa-1 & $\mathrm{C}, \mathrm{S}, \mathrm{T}$ & 4,255 & \\
\hline 403613112274601 & (C-2-5)31bbd-3 & $\mathrm{C}, \mathrm{S}, \mathrm{T}$ & 4,280 & \\
\hline 403602112272401 & (C-2-5)31bdd-3 & $\mathrm{S}, \mathrm{T}$ & & \\
\hline 403547112265201 & $(\mathrm{C}-2-5) 31$ dad-3 & $\mathrm{S}, \mathrm{T}$ & & \\
\hline 403609112253801 & (C-2-5)33bcb-3 & $\mathrm{S}, \mathrm{T}$ & & \\
\hline 403547112244401 & $(\mathrm{C}-2-5) 33 \mathrm{dcd}-1$ & $\mathrm{C}, \mathrm{S}, \mathrm{T}$ & 4,284 & \\
\hline 403619112235001 & $(C-2-5) 34 a b c-1$ & $\mathrm{C}, \mathrm{S}, \mathrm{T}$ & 4,294 & \\
\hline 403540112232201 & (C-2-5)34ddd-1 & $\mathrm{T}$ & & \\
\hline 403614112221701 & (C-2-5)35ada-1 & $\mathrm{T}$ & & \\
\hline 403606112221201 & (C-2-5)35add-1 & $\mathrm{S}, \mathrm{T}$ & & \\
\hline 403615111230301 & $(C-2-5) 35 c a b-1$ & & & M \\
\hline 403555112230301 & (C-2-5)35cbd-1 & $\mathrm{T}$ & & \\
\hline 403555112230303 & (C-2-5)35cbd-3 & $\mathrm{C}, \mathrm{T}$ & 4,291 & \\
\hline 403605112214201 & (C-2-5)36bdd-1 & & & M \\
\hline 403604112215801 & (C-2-5)36cba-2 & & & M \\
\hline 403557112210601 & $(\mathrm{C}-2-5) 36 \mathrm{dad}-2$ & & & M \\
\hline 403802112301201 & $(\mathrm{C}-2-6) 23 \mathrm{cbb}-1$ & & & M \\
\hline 403718112295602 & $(\mathrm{C}-2-6) 23 \mathrm{cdc}-2$ & $\mathrm{~S}, \mathrm{~T}$ & & \\
\hline 403740112290501 & $(\mathrm{C}-2-6) 24 \mathrm{cbb}-2$ & $\mathrm{~S}, \mathrm{~T}$ & & \\
\hline 403739112290501 & $(\mathrm{C}-2-6) 24 \mathrm{cbb}-3$ & $\mathrm{C}, \mathrm{T}$ & 4,256 & M \\
\hline 403706112292001 & (C-2-6)25abd-1 & $\mathrm{S}, \mathrm{T}$ & & \\
\hline 403630112292301 & (C-2-6)26dcd-1 & $\mathrm{C}, \mathrm{T}$ & 4,255 & \\
\hline 403539112282901 & $(C-2-6) 36 d c c-1$ & $\mathrm{C}, \mathrm{S}, \mathrm{T}$ & 4,278 & \\
\hline 403457112113401 & (C-3-3)4ccb & & & M \\
\hline 403309112115501 & (C-3-3)17ddc & & & $\mathrm{M}$ \\
\hline 403240112121801 & $(\mathrm{C}-3-3) 20 \mathrm{acb}-1$ & $\mathrm{C}, \mathrm{T}$ & 5,443 & $\mathrm{O}, \mathrm{TR}$ \\
\hline 403002112123201 & $(\mathrm{C}-3-3) 20 \mathrm{bab}-1$ & $\mathrm{C}, \mathrm{T}$ & 5,455 & \\
\hline 403258112123201 & (C-3-3)20bad-S1 & & & M \\
\hline 403151112112001 & (C-3-3)28bcd-2 & & & $\mathrm{M}, \mathrm{O}$ \\
\hline 403535112160001 & (C-3-4)2bad-1 & & & $\mathrm{M}, \mathrm{O}, \mathrm{TR}$ \\
\hline 403517112162001 & (C-3-4)2bcd-1 & & & M \\
\hline 403518112160301 & (C-3-4)2bdc-1 & & & $\mathrm{M}, \mathrm{O}, \mathrm{TR}$ \\
\hline 403452112165901 & (C-3-4)3dcc-1 & & & $\mathrm{M}, \mathrm{TR}$ \\
\hline 403533112180201 & (C-3-4)4abd-1 & $\mathrm{T}$ & & \\
\hline 403534112183701 & (C-3-4)4bbb-1 & $\mathrm{T}$ & & \\
\hline 403447112184401 & (C-3-4)8aaa-1 & $\mathrm{T}$ & & \\
\hline
\end{tabular}


Table C1. U.S. Geological Survey site identification number, local well number, and use of data for selected wells with water levels and water quality, Tooele Valley ground-water basin, Tooele County, Utah.-Continued

[Spring 2003 water-level altitude determined from water levels measured by the U.S. Geological Survey from March 12 to April 2, 2003. Water-quality samples collected by the U.S. Geological Survey from 2003 to 2006. Site identification number: A unique identification number assigned to each site in the USGS's Ground-Water Site Inventory system; Local well number, see figure 2 for explanation; B, wells used for aquifer interference tests; C, water-level contour map for spring 2003; G, dissolved-gas analysis; M, major ions, nutrients, and arsenic analysis; O, deuterium/oxygen-18 analysis; S, steady-state model calibration; T, transient model calibration; TR, tritium analysis; blank areas indicate that water-level or water-quality data were not available]

\begin{tabular}{|c|c|c|c|c|}
\hline $\begin{array}{c}\text { Site } \\
\text { identification } \\
\text { number }\end{array}$ & $\begin{array}{c}\text { Local } \\
\text { well number }\end{array}$ & $\begin{array}{l}\text { Water- } \\
\text { level } \\
\text { use }\end{array}$ & $\begin{array}{c}\text { Spring } 2003 \\
\text { water-level } \\
\text { altitude }\end{array}$ & $\begin{array}{l}\text { Water- } \\
\text { quality } \\
\text { use }\end{array}$ \\
\hline 403447112173801 & (C-3-4)9aaa-1 & $\mathrm{C}, \mathrm{T}$ & 4,376 & \\
\hline 403359112162801 & (C-3-4)10ddd-1 & $\mathrm{C}, \mathrm{T}$ & 4,392 & $\mathrm{O}$ \\
\hline 403400112150201 & $(\mathrm{C}-3-4) 12 \mathrm{cdc}-1$ & & & M \\
\hline 403407112144001 & $(\mathrm{C}-3-4) 13 \mathrm{aac}-1$ & & & M \\
\hline 403353112144401 & $(C-3-4) 13 a b b-1$ & $\mathrm{~T}$ & & TR \\
\hline 403400112144001 & $(\mathrm{C}-3-4) 13 \mathrm{abb}-2$ & $\mathrm{C}, \mathrm{T}$ & 4,406 & \\
\hline 403352112151601 & $(C-3-4) 13 b b b-1$ & & & $\mathrm{M}, \mathrm{TR}$ \\
\hline 403318112145401 & $(C-3-4) 13 c d b-1$ & & & $\mathrm{O}$ \\
\hline 403339112152501 & $(C-3-4) 14 a d b-1$ & $\mathrm{C}, \mathrm{T}$ & 4,395 & $\mathrm{O}$ \\
\hline 403355112173601 & (C-3-4)16aaa-1 & $\mathrm{C}, \mathrm{T}$ & 4,375 & \\
\hline 403332112191501 & $(\mathrm{C}-3-4) 17$ acc-1 & $\mathrm{C}, \mathrm{T}$ & 4,378 & \\
\hline 403316112193701 & (C-3-4)17cac-1 & & & $\mathrm{M}, \mathrm{TR}, \mathrm{G}$ \\
\hline 403218112200501 & $(C-3-4) 19 d d b-1$ & $\mathrm{~T}$ & & \\
\hline 403232112181601 & $(\mathrm{C}-3-4) 21 \mathrm{cab}-1$ & $\mathrm{C}, \mathrm{T}$ & 4,460 & $\mathrm{O}$ \\
\hline 403259112170101 & $(\mathrm{C}-3-4) 22$ baa-1 & $\mathrm{C}, \mathrm{T}$ & 4,389 & $\mathrm{O}$ \\
\hline 403253112170401 & $(\mathrm{C}-3-4) 22 \mathrm{bad}-1$ & & & $\mathrm{M}, \mathrm{TR}, \mathrm{G}$ \\
\hline 403201112140901 & $(\mathrm{C}-3-4) 25$ aad-1 & $\mathrm{T}$ & & \\
\hline 403155112153601 & (C-3-4)26aca-1 & $\mathrm{T}$ & & \\
\hline 403122112181901 & $(\mathrm{C}-3-4) 28 \mathrm{cdc}-2$ & $\mathrm{~T}$ & & \\
\hline 403202112200001 & (C-3-4)30aac-1 & $\mathrm{C}, \mathrm{T}$ & 4,469 & \\
\hline 403053112194601 & $(C-3-4) 32 b c c-1$ & $\mathrm{~T}$ & & \\
\hline 403111112175201 & (C-3-4)33abd-1 & $\mathrm{B}, \mathrm{C}, \mathrm{T}$ & 4,991 & \\
\hline 403059112175701 & $(\mathrm{C}-3-4) 33$ acd-1 & $\mathrm{T}$ & & \\
\hline 403059112175702 & $(\mathrm{C}-3-4) 33$ acd-2 & $\mathrm{B}$ & & \\
\hline 403049112182501 & $(\mathrm{C}-3-4) 33 \mathrm{cba}-1$ & $\mathrm{C}, \mathrm{T}$ & 4,978 & M \\
\hline 403038112183801 & $(\mathrm{C}-3-4) 33 \mathrm{ccb}-1$ & $\mathrm{C}, \mathrm{T}$ & 4,994 & \\
\hline 403048112174401 & $(\mathrm{C}-3-4) 33 \mathrm{dab}-1$ & $\mathrm{~T}$ & & \\
\hline 403040112174501 & $(\mathrm{C}-3-4) 33 \mathrm{dac}-1$ & $\mathrm{~B}, \mathrm{~T}$ & & \\
\hline 403110112165701 & $(\mathrm{C}-3-4) 34 \mathrm{bad}-1$ & B & & \\
\hline 403109112153003 & $(\mathrm{C}-3-4) 35 \mathrm{aac}-3$ & & & M \\
\hline 403115112153303 & $(C-3-4) 35 a b a-3$ & $\mathrm{~T}$ & & \\
\hline 403056112153701 & (C-3-4)35acd-1 & $\mathrm{B}, \mathrm{C}, \mathrm{T}$ & 5,547 & \\
\hline 403100112152001 & (C-3-4)35add-1 & $\mathrm{T}$ & & \\
\hline 403100112152002 & (C-3-4)35add-2 & $\mathrm{T}$ & & \\
\hline 403100112152003 & (C-3-4)35add-3 & $\mathrm{B}, \mathrm{C}, \mathrm{T}$ & 5,478 & \\
\hline 403050112161401 & $(\mathrm{C}-3-4) 35 \mathrm{cbb}-1$ & B & & \\
\hline 403520112212401 & (C-3-5)1aca-1 & $\mathrm{T}$ & & \\
\hline 403532112253601 & $(\mathrm{C}-3-5) 4 \mathrm{bbb}-2$ & $\mathrm{C}, \mathrm{S}, \mathrm{T}$ & 4,299 & \\
\hline 403429112272001 & $(C-3-5) 7 a b c-1$ & $\mathrm{C}, \mathrm{S}, \mathrm{T}$ & 4,275 & \\
\hline 403350112271801 & $(\mathrm{C}-3-5) 7 \mathrm{dcc}-1$ & $\mathrm{C}, \mathrm{S}, \mathrm{T}$ & 4,296 & \\
\hline 403419112222001 & $(\mathrm{C}-3-5) 11$ bad-1 & $\mathrm{C}, \mathrm{T}$ & 4,309 & \\
\hline 403335112211101 & (C-3-5)13adb-1 & $\mathrm{T}$ & & \\
\hline 403343112215901 & (C-3-5)13bbd-1 & $\mathrm{T}$ & & \\
\hline 403310112220201 & $(\mathrm{C}-3-5) 13 \mathrm{ccb}-1$ & $\mathrm{~T}$ & & \\
\hline 403234112232601 & $(\mathrm{C}-3-5) 22 \mathrm{dab}-1$ & $\mathrm{C}, \mathrm{T}$ & 4,315 & \\
\hline 403210112220001 & $(\mathrm{C}-3-5) 24 \mathrm{ccc}-1$ & $\mathrm{~T}$ & & \\
\hline 403228112211001 & $(\mathrm{C}-3-5) 24 \mathrm{dac}-1$ & $\mathrm{~T}$ & & \\
\hline 403147112210201 & (C-3-5)25add-1 & $\mathrm{T}$ & & \\
\hline
\end{tabular}

\begin{tabular}{|c|c|c|c|c|}
\hline $\begin{array}{c}\text { Site } \\
\text { identification } \\
\text { number }\end{array}$ & $\begin{array}{c}\text { Local } \\
\text { well number }\end{array}$ & $\begin{array}{l}\text { Water- } \\
\text { level } \\
\text { use }\end{array}$ & $\begin{array}{c}\text { Spring } 2003 \\
\text { water-level } \\
\text { altitude }\end{array}$ & $\begin{array}{l}\text { Water- } \\
\text { quality } \\
\text { use }\end{array}$ \\
\hline 403138112214801 & $(C-3-5) 25 \mathrm{cac}-1$ & $\mathrm{~T}$ & & \\
\hline 403135112212001 & (C-3-5)25dbd-1 & $\mathrm{T}$ & & \\
\hline 403204112222901 & (C-3-5)26aba-1 & $\mathrm{T}$ & & \\
\hline 403030112210001 & (C-3-5)36ddd-1 & $\mathrm{C}, \mathrm{T}$ & 4,477 & \\
\hline 403514112283701 & (C-3-6)1bdb-1 & $\mathrm{C}, \mathrm{S}, \mathrm{T}$ & 4,277 & $\mathrm{O}, \mathrm{TR}, \mathrm{G}$ \\
\hline 403335112283201 & (C-3-6)13bda-1 & & & $\mathrm{M}, \mathrm{O}$ \\
\hline 403035112325501 & $(\mathrm{C}-3-6) 32 \mathrm{dbc}-1$ & $\mathrm{~T}$ & & \\
\hline 403035112324301 & (C-3-6)32dbd-1 & $\mathrm{T}$ & & \\
\hline 402932112155401 & (C-4-4)11baa-S1 & & & M \\
\hline 402836112205001 & (C-4-4)18bbb-1 & $\mathrm{T}$ & & \\
\hline 402544112192901 & $(\mathrm{C}-4-4) 32 \mathrm{cab}-1$ & & & M \\
\hline 402912112201501 & (C-4-5)8bdc-1 & $\mathrm{T}$ & & \\
\hline 402619112220201 & (C-4-5)26dda-1 & $\mathrm{T}$ & & \\
\hline 402615112235201 & $(C-4-5) 27 c d b-1$ & $\mathrm{~T}$ & & \\
\hline 402637112261101 & (C-4-5)29bdc-1 & $\mathrm{T}$ & 4,761 & \\
\hline 402627112252801 & (C-4-5)29daa-1 & $\mathrm{T}$ & 4,757 & \\
\hline 402648112270601 & $(\mathrm{C}-4-5) 30 \mathrm{aac}-1$ & $\mathrm{~T}$ & & \\
\hline 402645112265101 & $(\mathrm{C}-4-5) 30 \mathrm{aac}-2$ & & & $\mathrm{M}, \mathrm{TR}, \mathrm{G}$ \\
\hline 402525112251502 & $(\mathrm{C}-4-5) 32 \mathrm{cca}-2$ & & & M \\
\hline 402526112252001 & (C-4-5)33cca-1 & $\mathrm{S}, \mathrm{T}$ & & \\
\hline 402954112280901 & (C-4-6)1dbb-1 & $\mathrm{T}$ & & \\
\hline 403009112310301 & (C-4-6)3bbc-1 & $\mathrm{T}$ & & \\
\hline 402500112230001 & $(C-5-5) 2 b c b-1$ & $\mathrm{~S}, \mathrm{~T}$ & & \\
\hline 402514112254301 & (C-5-5)5aab-1 & $\mathrm{T}$ & & M \\
\hline 402453112261101 & $(\mathrm{C}-5-5) 5 \mathrm{bdb}-1$ & $\mathrm{~T}$ & 4,965 & \\
\hline 402316112250701 & (C-5-5)16bbd-1 & $\mathrm{T}$ & & \\
\hline 402238112254201 & (C-5-5)17ded-1 & $\mathrm{T}$ & & \\
\hline 402203112264001 & (C-5-5)19dac-1 & $\mathrm{T}$ & & \\
\hline 402213112255201 & $(\mathrm{C}-5-5) 20 \mathrm{acc}-3$ & $\mathrm{~T}$ & & \\
\hline 402210112262701 & $(\mathrm{C}-5-5) 20 \mathrm{bcc}-1$ & $\mathrm{~T}$ & & \\
\hline 402208112251901 & (C-5-5)20daa-1 & $\mathrm{T}$ & & \\
\hline 402208112251902 & (C-5-5)20daa-2 & $\mathrm{T}$ & 5,002 & \\
\hline 402113112252001 & (C-5-5)29daa-1 & $\mathrm{T}$ & & \\
\hline 402124112270601 & $(\mathrm{C}-5-5) 30 \mathrm{bda}-2$ & $\mathrm{~T}$ & 5,043 & \\
\hline 402015112263502 & $(\mathrm{C}-5-5) 31 \mathrm{dbd}-2$ & $\mathrm{~S}, \mathrm{~T}$ & & \\
\hline 402041112255101 & (C-5-5)32abc-1 & $\mathrm{T}$ & & \\
\hline 402024112254601 & $(C-5-5) 32 d b b-2$ & & & M \\
\hline 402032112251701 & (C-5-5)33bcc-1 & $\mathrm{T}$ & & \\
\hline 402415112280501 & $(\mathrm{C}-5-6) 12 \mathrm{aba}-1$ & $\mathrm{~T}$ & & \\
\hline 402012112275201 & $(\mathrm{C}-5-6) 36 \mathrm{dac}-1$ & $\mathrm{~T}$ & & \\
\hline 401947112260901 & (C-6-5)5bac-2 & $\mathrm{T}$ & & \\
\hline 401856112254701 & (C-6-5)8abc-1 & $\mathrm{T}$ & & \\
\hline 401851112243101 & (C-6-5)9acb-1 & $\mathrm{T}$ & & \\
\hline 401740112242401 & (C-6-5)16dbd-1 & $\mathrm{T}$ & & \\
\hline 401810112294901 & $(C-6-6) 14 b b b-1$ & $\mathrm{~T}$ & & \\
\hline 401653112280201 & (C-6-6)24dbb-1 & $\mathrm{T}$ & & \\
\hline
\end{tabular}

${ }^{1}$ Water level measured by Kennecott Utah Copper Corporation, February $10,2003$. 


\section{C-4 Hydrology and Simulation of Ground-Water Flow in the Tooele Valley Ground-Water Basin, Tooele County, Utah}

Table C2. Well name and water-level use for selected Tooele Army Depot wells with water-level data, Tooele Valley ground-water basin, Tooele County, Utah.

[Spring 2003 water-level altitude determined from water levels measured by Tooele Army Depot from March 5 to March 12, 2003. C, water-level contour map for spring 2003; T, transient model calibration; blank indicates no water-level data available for spring 2003]

\begin{tabular}{|c|c|c|}
\hline $\begin{array}{l}\text { Tooele Army Depot } \\
\text { well name }\end{array}$ & Water-level use & $\begin{array}{l}\text { Spring } 2003 \text { water-level } \\
\text { altitude, in feet }\end{array}$ \\
\hline $\mathrm{A}-03$ & $\mathrm{~T}$ & \\
\hline B-03 & $\mathrm{C}, \mathrm{T}$ & 4,465 \\
\hline B-06 & $\mathrm{C}, \mathrm{T}$ & 4,308 \\
\hline B-09 & $\mathrm{C}, \mathrm{T}$ & 4,342 \\
\hline B-12 & $\mathrm{C}, \mathrm{T}$ & 4,303 \\
\hline B-21 & $\mathrm{C}, \mathrm{T}$ & 4,441 \\
\hline B-23 & $\mathrm{C}, \mathrm{T}$ & 4,464 \\
\hline B-24 & $\mathrm{C}, \mathrm{T}$ & 4,341 \\
\hline B-28 & $\mathrm{C}, \mathrm{T}$ & 4,314 \\
\hline B-29 & $\mathrm{C}, \mathrm{T}$ & 4,302 \\
\hline B-32 & $\mathrm{C}, \mathrm{T}$ & 4,304 \\
\hline B-36 & $\mathrm{C}, \mathrm{T}$ & 4,461 \\
\hline B-37 & $\mathrm{C}, \mathrm{T}$ & 4,301 \\
\hline B-38 & $\mathrm{C}, \mathrm{T}$ & 4,304 \\
\hline B-44 & $\mathrm{C}, \mathrm{T}$ & 4,301 \\
\hline B-45 & $\mathrm{C}, \mathrm{T}$ & 4,304 \\
\hline B-47 & $\mathrm{C}, \mathrm{T}$ & 4,300 \\
\hline B-48 & $\mathrm{C}, \mathrm{T}$ & 4,304 \\
\hline B-54 & $\mathrm{C}, \mathrm{T}$ & 4,466 \\
\hline B-56 & $\mathrm{C}, \mathrm{T}$ & 4,338 \\
\hline B-58 & $\mathrm{C}, \mathrm{T}$ & 4,340 \\
\hline B-59 & $\mathrm{C}, \mathrm{T}$ & 4,304 \\
\hline B-60 & $\mathrm{C}, \mathrm{T}$ & 4,303 \\
\hline $\mathrm{C}-06$ & $\mathrm{C}, \mathrm{T}$ & 4,306 \\
\hline $\mathrm{C}-08$ & $\mathrm{C}, \mathrm{T}$ & 4,305 \\
\hline C-09 & $\mathrm{C}, \mathrm{T}$ & 4,341 \\
\hline $\mathrm{C}-10$ & $\mathrm{~T}$ & \\
\hline $\mathrm{C}-13$ & $\mathrm{C}, \mathrm{T}$ & 4,457 \\
\hline $\mathrm{C}-14$ & $\mathrm{C}, \mathrm{T}$ & 4,456 \\
\hline $\mathrm{C}-18$ & $\mathrm{C}, \mathrm{T}$ & 4,464 \\
\hline $\mathrm{C}-23$ & $\mathrm{C}, \mathrm{T}$ & 4,470 \\
\hline $\mathrm{C}-25$ & $\mathrm{C}, \mathrm{T}$ & 4,340 \\
\hline C-29 & $\mathrm{C}, \mathrm{T}$ & 4,467 \\
\hline C-32 & $\mathrm{C}, \mathrm{T}$ & 4,467 \\
\hline C-35 & $\mathrm{C}, \mathrm{T}$ & 4,468 \\
\hline D-01 & $\mathrm{C}, \mathrm{T}$ & 4,373 \\
\hline D-02 & $\mathrm{C}, \mathrm{T}$ & 4,376 \\
\hline D-03 & $\mathrm{C}, \mathrm{T}$ & 4,350 \\
\hline D-04 & $\mathrm{C}, \mathrm{T}$ & 4,374 \\
\hline D-05 & $\mathrm{C}, \mathrm{T}$ & 4,369 \\
\hline D-06 & $\mathrm{C}, \mathrm{T}$ & 4,373 \\
\hline D-07 & $\mathrm{C}, \mathrm{T}$ & 4,370 \\
\hline D-09 & $\mathrm{C}, \mathrm{T}$ & 4,330 \\
\hline D-10 & $\mathrm{C}, \mathrm{T}$ & 4,304 \\
\hline E-01 & $\mathrm{T}$ & \\
\hline E-02-1 & $\mathrm{T}$ & \\
\hline E-02-2 & $\mathrm{T}$ & \\
\hline E-03-1 & $\mathrm{T}$ & \\
\hline E-03-2 & $\mathrm{T}$ & \\
\hline E-04 & $\mathrm{T}$ & \\
\hline E-06 & $\mathrm{T}$ & \\
\hline E-13 & $\mathrm{T}$ & \\
\hline E-14 & $\mathrm{T}$ & \\
\hline
\end{tabular}

\begin{tabular}{|c|c|c|}
\hline $\begin{array}{l}\text { Tooele Army Depot } \\
\text { well name }\end{array}$ & Water-level use & $\begin{array}{l}\text { Spring } 2003 \text { water-level } \\
\text { altitude, in feet }\end{array}$ \\
\hline E-15 & $\mathrm{T}$ & \\
\hline $\mathrm{N}-02 \mathrm{C}$ & $\mathrm{T}$ & \\
\hline N-08B & $\mathrm{C}, \mathrm{T}$ & 4,305 \\
\hline N-110-88 & $\mathrm{C}, \mathrm{T}$ & 4,469 \\
\hline N-118-88 & $\mathrm{C}, \mathrm{T}$ & 4,471 \\
\hline $\mathrm{N}-127-88$ & $\mathrm{C}, \mathrm{T}$ & 4,469 \\
\hline$N-131-90$ & $\mathrm{C}, \mathrm{T}$ & 4,467 \\
\hline N-133-90 & $\mathrm{C}, \mathrm{T}$ & 4,467 \\
\hline N-135-90 & $\mathrm{C}, \mathrm{T}$ & 4,469 \\
\hline N-137-90 & $\mathrm{C}, \mathrm{T}$ & 4,352 \\
\hline N-139-90 & $\mathrm{C}, \mathrm{T}$ & 4,387 \\
\hline N-140-93 & $\mathrm{C}, \mathrm{T}$ & 4,338 \\
\hline $\mathrm{N}-141-93$ & $\mathrm{C}, \mathrm{T}$ & 4,356 \\
\hline $\mathrm{N}-145-93$ & $\mathrm{C}, \mathrm{T}$ & 4,394 \\
\hline P-01D & $\mathrm{C}, \mathrm{T}$ & 4,467 \\
\hline P-02D & $\mathrm{T}$ & \\
\hline P-03D & $\mathrm{C}, \mathrm{T}$ & 4,447 \\
\hline P-03S & $\mathrm{C}, \mathrm{T}$ & 4,463 \\
\hline P-04D & $\mathrm{C}, \mathrm{T}$ & 4,467 \\
\hline P-06D & $\mathrm{C}, \mathrm{T}$ & 4,465 \\
\hline P-07D & $\mathrm{C}, \mathrm{T}$ & 4,459 \\
\hline P-08D & $\mathrm{C}, \mathrm{T}$ & 4,339 \\
\hline P-10S & $\mathrm{C}, \mathrm{T}$ & 4,457 \\
\hline P-11D & $\mathrm{C}, \mathrm{T}$ & 4,342 \\
\hline P-12D & $\mathrm{C}, \mathrm{T}$ & 4,340 \\
\hline P-13D & $\mathrm{C}, \mathrm{T}$ & 4,308 \\
\hline P-14D & $\mathrm{C}, \mathrm{T}$ & 4,340 \\
\hline P-15D & C.T & 4,303 \\
\hline P-16D & $\mathrm{C}, \mathrm{T}$ & 4,304 \\
\hline P-17D & $\mathrm{C}, \mathrm{T}$ & 4,305 \\
\hline P-19D & $\mathrm{C}, \mathrm{T}$ & 4,304 \\
\hline $\mathrm{P}-24 \mathrm{D}$ & $\mathrm{C}, \mathrm{T}$ & 4,307 \\
\hline $\mathrm{P}-25 \mathrm{D}$ & $\mathrm{C}, \mathrm{T}$ & 4,459 \\
\hline P-25S & $\mathrm{C}, \mathrm{T}$ & 4,463 \\
\hline P-26S & $\mathrm{C}, \mathrm{T}$ & 4,307 \\
\hline P-27D & $\mathrm{C}, \mathrm{T}$ & 4,340 \\
\hline P-28D & $\mathrm{C}, \mathrm{T}$ & 4,305 \\
\hline P-29 & $\mathrm{C}, \mathrm{T}$ & 4,466 \\
\hline P-36 & $\mathrm{C}, \mathrm{T}$ & 4,301 \\
\hline P-40 & $\mathrm{C}, \mathrm{T}$ & 4,444 \\
\hline P-41 & $\mathrm{C}, \mathrm{T}$ & 4,457 \\
\hline P-42 & $\mathrm{C}, \mathrm{T}$ & 4,309 \\
\hline P-43 & $\mathrm{C}, \mathrm{T}$ & 4,309 \\
\hline P-44 & $\mathrm{C}, \mathrm{T}$ & 4,344 \\
\hline $\mathrm{T}-01$ & $\mathrm{~T}$ & \\
\hline $\mathrm{T}-02$ & $\mathrm{C}, \mathrm{T}$ & 4,441 \\
\hline $\mathrm{T}-03$ & $\mathrm{C}, \mathrm{T}$ & 4,467 \\
\hline $\mathrm{T}-04$ & $\mathrm{C}, \mathrm{T}$ & 4,446 \\
\hline $\mathrm{T}-05$ & $\mathrm{C}, \mathrm{T}$ & 4,340 \\
\hline T-06 & $\mathrm{C}, \mathrm{T}$ & 4,344 \\
\hline $\mathrm{T}-07$ & $\mathrm{C}, \mathrm{T}$ & 4,470 \\
\hline WW-08 & $\mathrm{T}$ & \\
\hline
\end{tabular}


Table C3. Discharge of selected springs from 2003 to 2005, Tooele Valley ground-water basin, Tooele County, Utah.

[Location of measurement, see figure 2 for explanation; discharge in cubic feet per second]

\begin{tabular}{|c|c|c|}
\hline $\begin{array}{c}\text { Date of } \\
\text { measurement }\end{array}$ & Location of measurement & Discharge \\
\hline \multicolumn{3}{|c|}{ Factory-Dunne Springs } \\
\hline $08-20-2003$ & & 10.06 \\
\hline $09-12-2003$ & & 7.47 \\
\hline $10-23-2003$ & & 8.40 \\
\hline $12-17-2003$ & & 11.16 \\
\hline 01-30-2004 & & 10.78 \\
\hline $03-31-2004$ & & 9.29 \\
\hline $04-12-2004$ & & 7.63 \\
\hline $06-29-2004$ & & 10.82 \\
\hline 07-26-2004 & & 9.07 \\
\hline $08-24-2004$ & & 10.64 \\
\hline 09-20-2004 & & 11.68 \\
\hline $10-22-2004$ & & 11.54 \\
\hline $11-18-2004$ & & 9.51 \\
\hline $12-28-2004$ & & 9.02 \\
\hline 03-08-2005 & & 9.18 \\
\hline 03-09-2005 & & 11.90 \\
\hline 06-08-2005 & & 11.00 \\
\hline 09-02-2005 & & 10.65 \\
\hline \multicolumn{3}{|c|}{ Sixmile Spring } \\
\hline $09-27-2004$ & & 3.96 \\
\hline $10-22-2004$ & & 4.87 \\
\hline $11-18-2004$ & & 4.30 \\
\hline $12-28-2004$ & & 4.24 \\
\hline 03-09-2005 & At diversion & 4.48 \\
\hline 03-09-2005 & 1 mile downstream & 4.65 \\
\hline 03-09-2005 & 2.2 miles downstream & 4.33 \\
\hline 06-08-2005 & & 4.08 \\
\hline $08-24-2005$ & & 3.93 \\
\hline \multicolumn{3}{|c|}{ Fishing Creek Spring } \\
\hline $09-11-2003$ & & 2.71 \\
\hline $11-24-2003$ & & 3.72 \\
\hline $12-17-2003$ & & 4.40 \\
\hline 03-29-2004 & & 4.64 \\
\hline $04-12-2004$ & & 5.16 \\
\hline $05-13-2004$ & & 5.37 \\
\hline $06-29-2004$ & & 3.70 \\
\hline $07-26-2004$ & & 2.60 \\
\hline $08-23-2004$ & & 3.79 \\
\hline $10-22-2004$ & & 3.55 \\
\hline $08-24-2005$ & & 2.54 \\
\hline \multicolumn{3}{|c|}{ Warm Springs } \\
\hline $02-02-2004$ & & 0.5 \\
\hline \multicolumn{3}{|c|}{ Springs in northwestern Tooele Valley } \\
\hline 06-24-2005 & & 4.60 \\
\hline
\end{tabular}




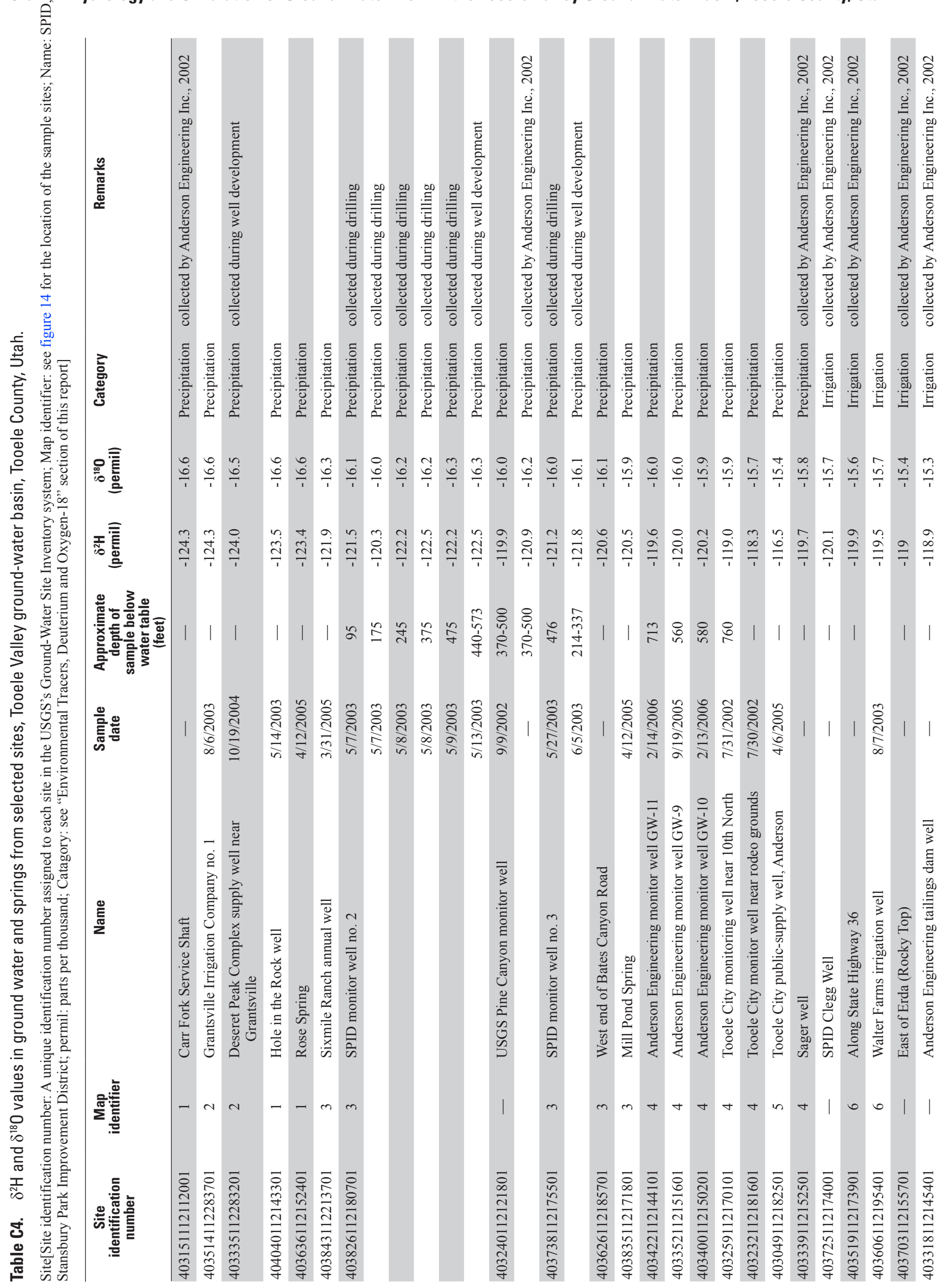




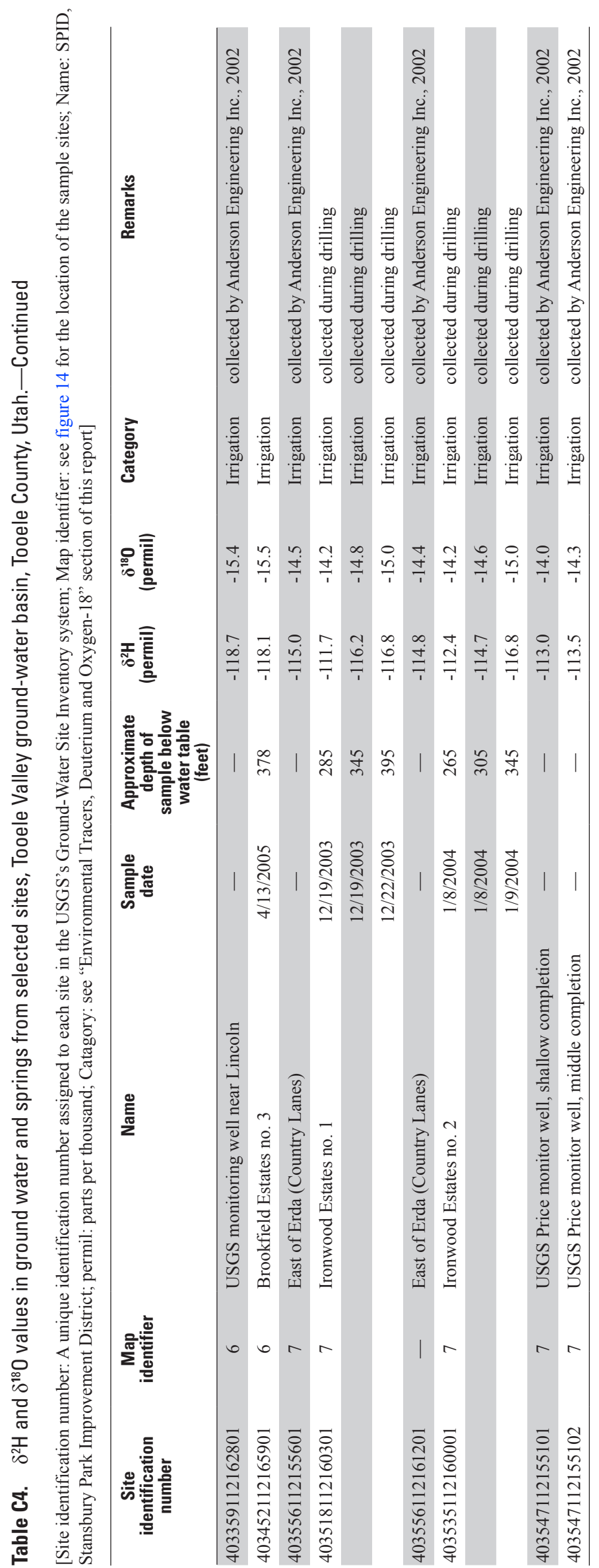




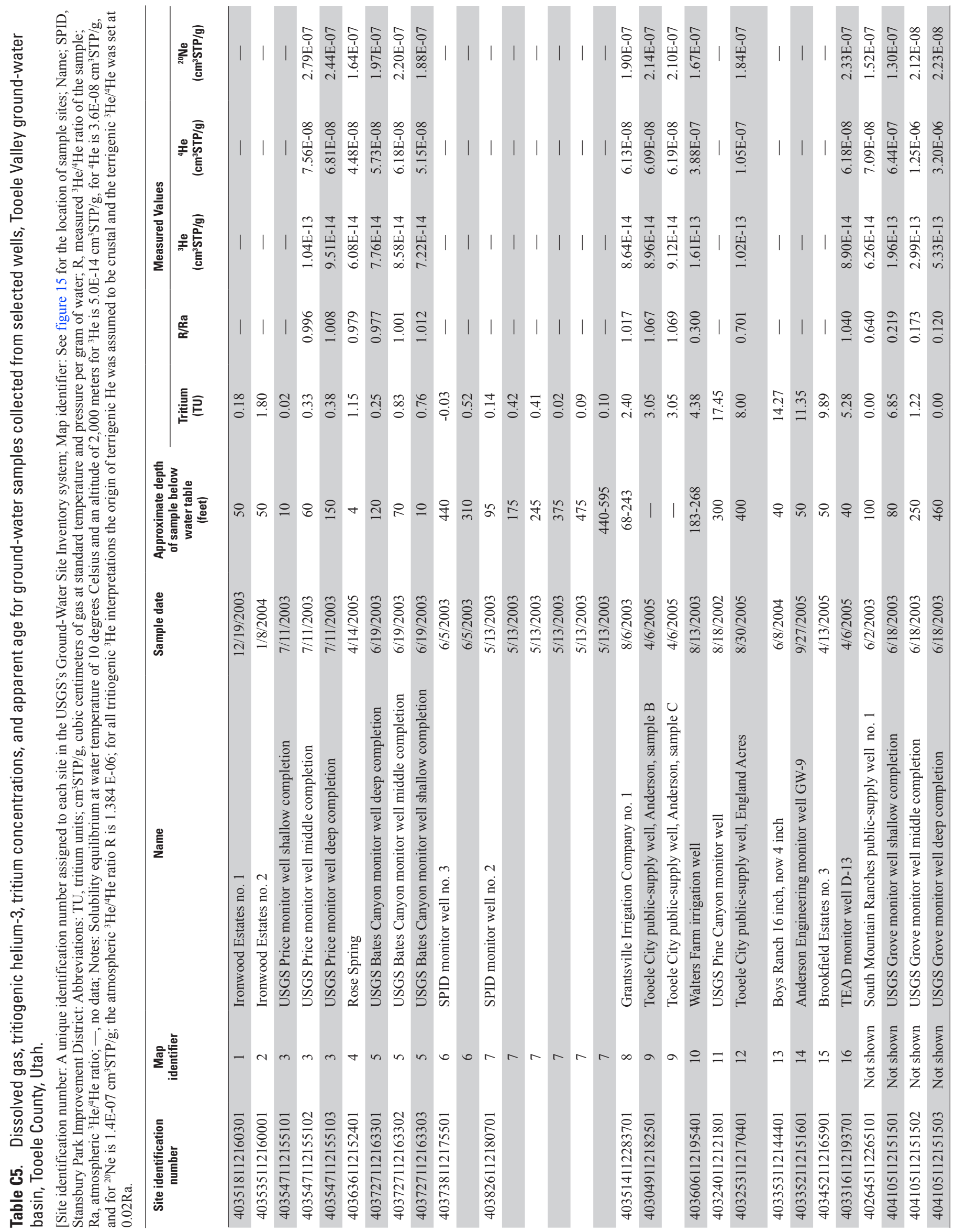




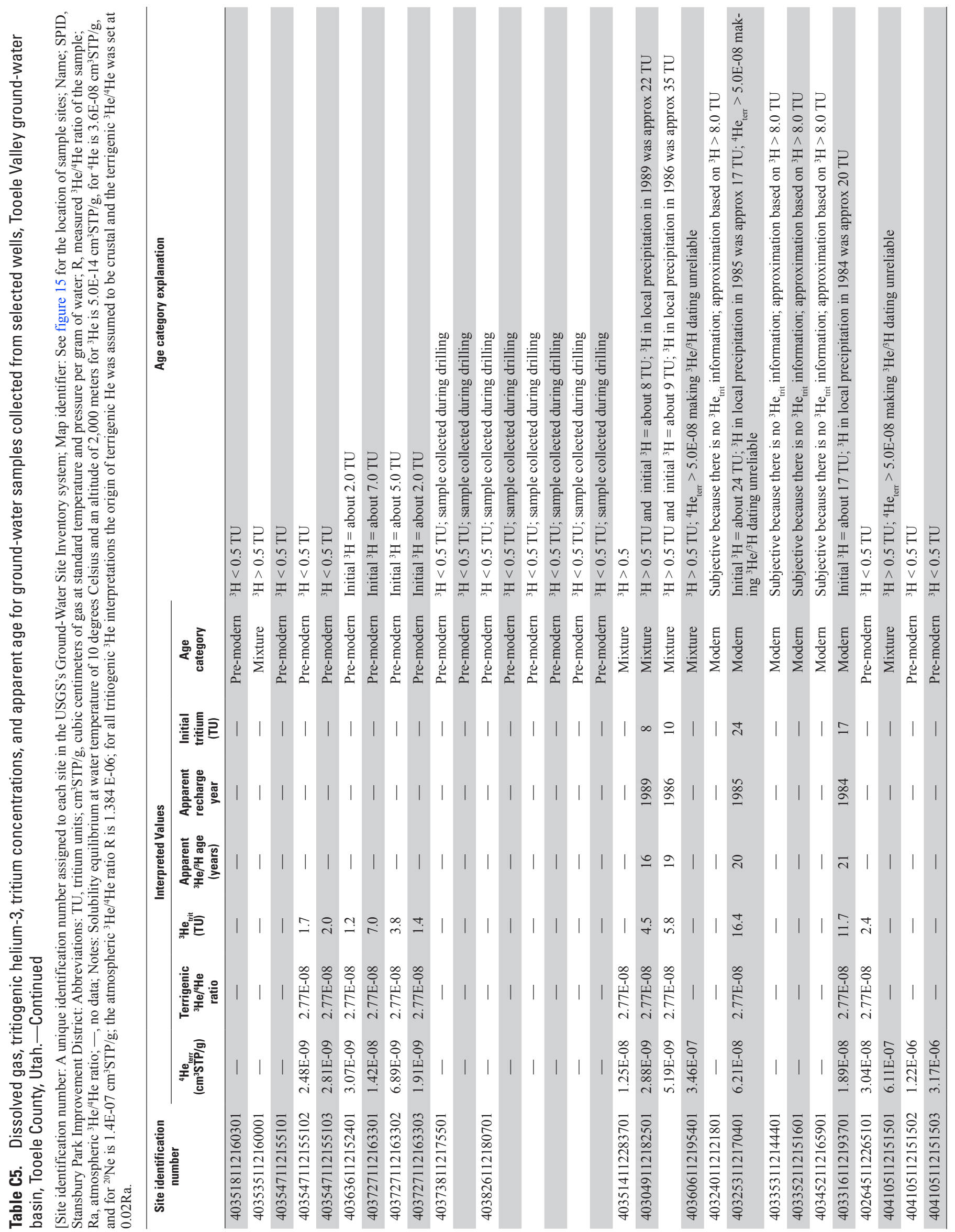


Table C6. Description of model parameters, ground-water flow model, Tooele Valley ground-water basin, Tooele County, Utah. [TEAD, Tooele Army Depot]

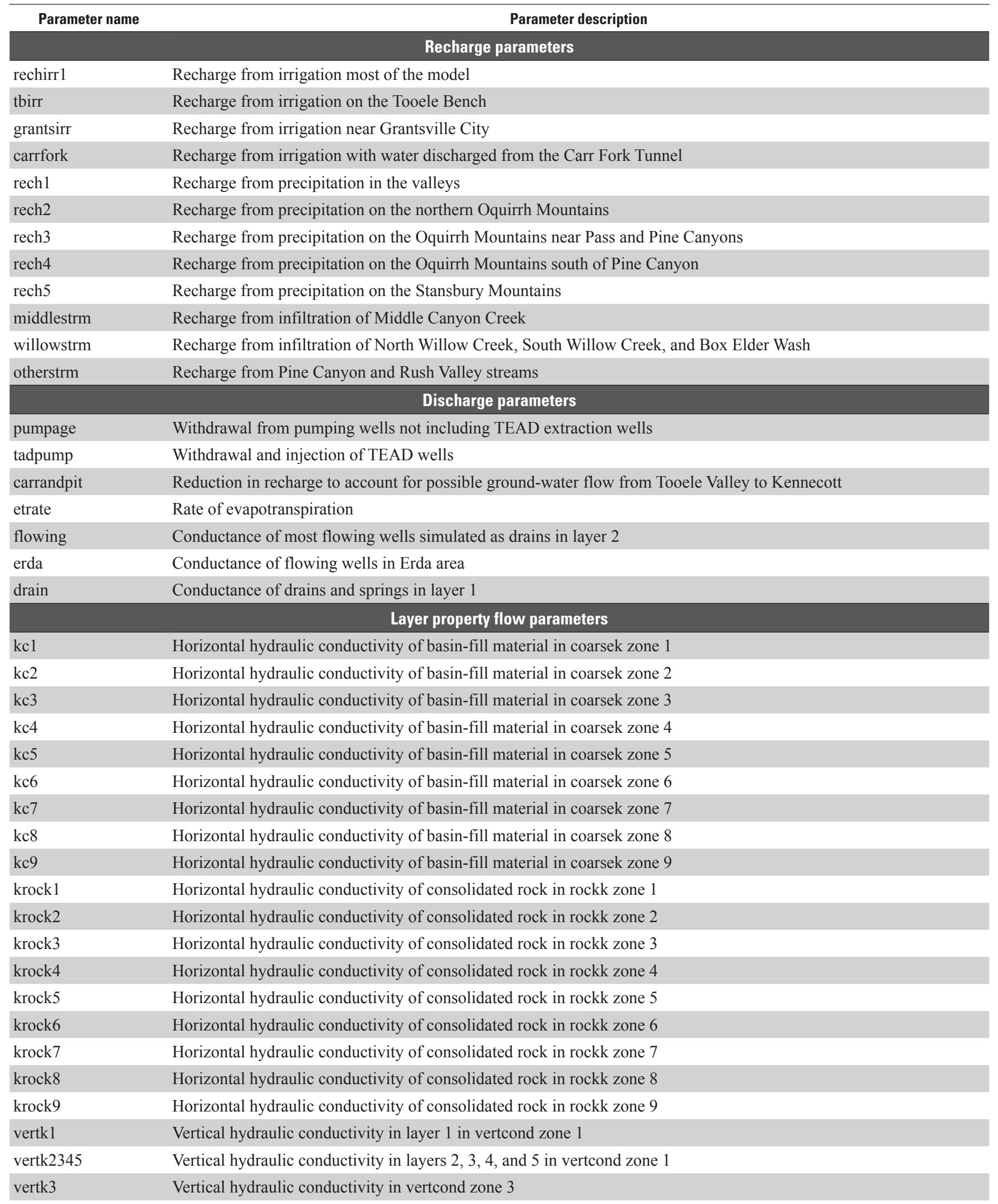


Table C6. Description of model parameters, ground-water flow model, Tooele Valley ground-water basin, Tooele County, Utah.Continued

[TEAD, Tooele Army Depot]

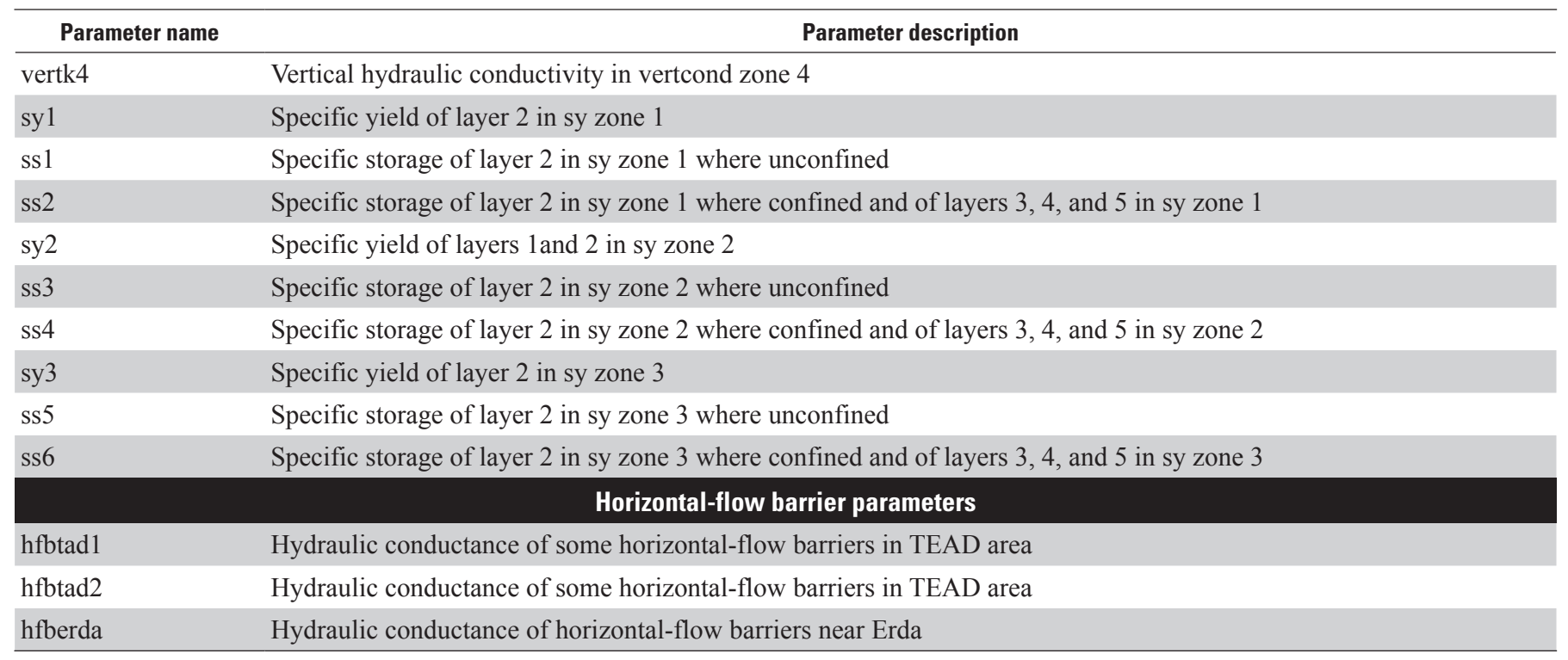





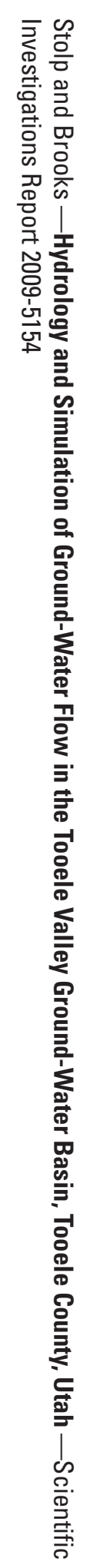

